\title{
BIOSSEGURANÇA PARA AGENTES BIOLÓGICOS NA PRÁTICA ASSISTENCIAL: UM ESTUDO EM HOSPITAIS DA REGIÃO DE ITABUNA-BA.
}

MARIDALVA DE SOUZA PENTEADO

Tese apresentada ao Departamento de Prática de Saúde Pública da Universidade de São Paulo para obtenção do grau de Doutor.

Área de Concentração:

Prática de Saúde Pública

ORIENTADOR: PROF. DR. FERNANDO LEFÈVRE

São Paulo

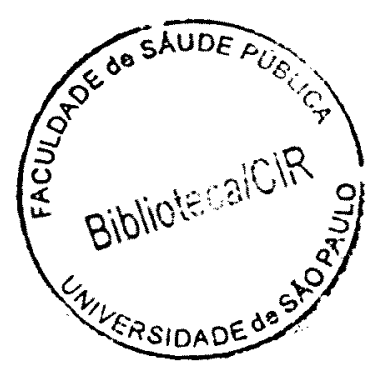


Autorizo, exclusivamente para fins acadêmicos e científicos, a reprodução total ou parcial desta tese, por processos fotocopiadores.

Assinatura:

Data:

$44002 / 2003 d x$ 
“ Se não houver frutos

valeu a beleza das flores

se não houver flores

valeu a sombra das folhas

se não houver folhas

valeu a intenção das sementes".

Henfil 
À José Luís Pires.

Sobretudo pelo companheirismo. 


\section{AGRADECIMENTOS}

Ao Dr. Fernando Lefèvre pela orientação e acolhida sempre gentil.

À Dr. ${ }^{a}$ Graziela Almeida Silva, Dr. ${ }^{a}$ Márcia de Souza, Dr. ${ }^{a}$ Sônia Regina Testa Silva Ramos e à Dr. ${ }^{a}$ Tânia Cristina de Oliveira pelas valiosas sugestões.

Ao José Luís Pires pela assessoria estatística.

Ao Dr. Paulo Fortes e à Dr. ${ }^{a}$ Evelyn Naked Castro Sá pelo especial zelo com que cuidaram da turma de Doutorado em Feira de Santana.

A todos os docentes do curso, pela competência e seriedade.

À administração superior da Universidade Estadual de Feira de Santana, representada pelo Departamento de Ciências da Saúde, na pessoa do Dr. Guido Rummler pela oportunidade do curso.

À administração superior e Departamento de Ciências da Saúde da Universidade Estadual de Santa Cruz pelo apoio.

À Dr. ${ }^{a}$ Denise Mary Cardo pelas sugestões ao projeto.

Aos dirigentes das instituições hospitalares pela oportunização da Coleta de Dados.

Aos profissionais que se disponibilizaram a responder nossas indagações, por tudo.

Às bibliotecárias da Faculdade de Saúde Pública, da Escola de Enfermagem da USP e da BIREME e ao corpo administrativo da Pós-Graduação da FSP, pela diligência.

A todos os amigos do curso pela rica convivência. Especialmente a Adélia Carvalho M. Pinheiro, Cristina Setenta Andrade, Sandra Furiam e Silvio R. M. Orrico. 
Aos solidários amigos Eliumar Silva, Eliuse Silva, Flávia Moura Costa, Luciana Leal e Vitória Cristina de Sant'Ana, pela inestimável ajuda.

Àqueles que não estão mencionados mas que de alguma maneira colaboraram para a concretização do estudo. 


\section{RESUMO}

Penteado, M S. Biossegurança para agentes biológicos na prática assistencial: Um estudo em hospitais da região de Itabuna- BA. São Paulo; 2003 [Tese de Doutorado- Faculdade de Saúde Pública da USP]

Trata-se de estudo com os seguintes objetivos: descrever a organização de aspectos estruturais relacionados à biossegurança nos hospitais sob a supervisão da Sétima Diretoria Regional da Bahia (Análise de Estrutura); verificar o grau de incorporação de práticas de auto- proteção(Biossegurança), por parte de profissionais atuantes em três desses mesmos hospitais, em procedimentos de punção venosa (Análise de Processo) e analisar as percepções dos profissionais de saúde atuantes nos hospitais, acerca dos riscos concernentes aos agentes biológicos em seu trabalho e acerca do preservar-se. A pesquisa divide-se em três momentos. No primeiro momento, descrevemos as estruturas hospitalares, tomando como base a presença de dezoito itens. Para análise dos resultados, os hospitais são comparados segundo sua classificação por porte, vinculação administrativo-financeira (hospitais públicos, privados e filantrópicos), categoria geral e especializada, constituir-se ou não em campo de atividades de ensino, dispor de corpo clínico aberto ou fechado, tipo de clientela atendida em respeito à forma de remuneração pelos serviços e localização geográfica das instituições. As instituições demonstram situação precária, no geral, à presença dos itens investigados. Contudo, há tendência a resultados pouco melhores, conforme maior o porte das instituições. Os resultados também apresentam-se pouco mais promissores nos hospitais campo de ensino e, no referente à categoria de gestão financeira, os hospitais filantrópicos mostram-se com melhores resultados a despeito dos públicos e privados. Mostra-se ainda elemento diferenciador do desempenho das instituições, a presença de grupo executor de controle de infecções hospitalares. $O$ segundo momento da pesquisa compreende estudo de observação, em que analisamos a incorporação de medidas de biossegurança na prática de punções venosas, por profissionais médicos, enfermeiros e auxiliares e técnicos de enfermagem, em três dos serviços hospitalares. Observamos diferenças nas aderências às medidas preconizadas durante o desenvolvimento dos procedimentos, 
por parte dos profissionais, entre os hospitais e entre setores das instituições. São, todavia, modestas as aderências, no geral, particularmente no referente à lavagem das mãos antes e após a execução das técnicas, o mesmo ocorrendo com o emprego de luvas. Resultados mais alvissareiros são averiguados para as recomendações de descarte imediato de agulhas e não re-encape do instrumento. Numa análise cruzada, os resultados das aderências a essas últimas medidas, mostraram-se mais promissores nos hospitais que, na análise de estrutura, apresentaram-se melhor posicionados. $\mathrm{O}$ inverso foi observado para as primeiras medidas (Lavagem das mãos e uso de luvas). Detectamos ainda haver diferenças nas adesões às práticas recomendadas por parte dos profissionais, de acordo com a faixa etária dos pacientes submetidos aos procedimentos em estudo. As aderências à lavagem das mãos previamente e após a técnica em questão, mostraram-se mais freqüentes quando do trato com infantes, ao passo que o descarte imediato das agulhas e o seu não re- encape, quando do trato com adultos. Há ainda tendência de que as profissionais do sexo feminino sejam mais aderentes, em particular à lavagem das mãos após a execução dos procedimentos em foco, que os profissionais do sexo masculino. Também se diferenciam, quanto à adesão às mesmas medidas, os profissionais quando categorizados conforme tempo de formado. Mostram-se melhor posicionados os profissionais com tempo de formado entre cinco e dez anos, quando comparados àqueles formados há menos e mais tempo respectivamente. No terceiro momento do estudo, analisamos as percepções dos profissionais envolvidos na prática assistencial, aqui também delimitados a médicos, enfermeiros e auxiliares e técnicos de enfermagem, acerca do preservar-se/contaminar-se, utilizando a técnica do Discurso do Sujeito Coletivo. Verificamos que os discursos evocados encaminham-se preponderantemente para a percepção de que atuam sob riscos biológicos, principalmente dos vírus de transmissão sangüínea com destaque para o HIV e, em menor instância, dos HBVs. Percebem que buscam se auto-protegerem principalmente com o uso de EPIs e desvelam que estão sujeitos às limitações estruturais das instituições nas quais atuam no referente à sua proteção. A análise indica que o repertório apresentado espelha a precariedade estrutural praticamente generalizada dos hospitais, no que diz respeito à biossegurança. Também, a própria representação social dos sujeitos acerca da temática, marcada por importante dose de 
alienação, deve ter suas influências sobre essas mesmas estruturas. Os achados vistos no seu conjunto, permitem- nos deduzir, em suma, que à construção de um adequado aparato de biossegurança, concorrem elementos estruturais, elementos relacionados aos distintos processos de trabalho e também detalhes relacionados às especificidades do fazer humano. Assim, inferimos que a discussão acerca da biossegurança deva ser tanto técnica quanto ética. Isso nos referindo à ética axiológica moderna, que fundamenta que a ação ética tem componentes afetivos e cognitivos. Como recomendações do trabalho, enfatizamos que esforços sejam empreendidos para que a biossegurança perpasse toda uma nova forma de pensar e agir na saúde; que os aparelhos formadores de recursos humanos para a área incorporem, nos seus conteúdos de ensino, a temática em questão; que as instituições, em particular os hospitais, não descuidem da educação continuada de seus profissionais no tocante ao assunto e que seja dada atenção pelos formuladores de políticas públicas, à análise da qualidade dos serviços de saúde, que leve em conta o cuidado também dos seus trabalhadores.

UNITERMOS: Biossegurança, hospitais, profissionais da saúde. 


\section{SUMMARY}

Penteado, M. S. Biosafeness for biological agents in assistencial praxis: A study in hospitals in the region of Itabuna - Bahia. São Paulo; 2003 [ Tese de Doutorado- Faculdade de Saúde Pública da USP]

This study has the following goals: describing the organization of structural aspects related to biosafeness in hospitals under the supervision of the official organ, Seventh Regional Directory of Bahia(Structural Analysis); verifying the degree of incorporation of self -protection practices by the professionals in three of these same hospitals during proceeding venipuncture(Process Analysis) and analyzing the professionals' perceptions towards the risks with biological agents in their work, and preserving themselves from contagious. In a first stage, hospitals structures are described having eighteen items as basis. For analysis of the results, hospitals are compared according to their classification, taking into account the following criteria: size, administrative and financial sphere( public hospitals, private hospitals and philanthropic hospitals), general and specialized categories, if the hospital is constituted or not in field of teaching activities, clinical staff restricted or non restricted, type of hospital clientele concerning to the manner of payment for the services done, and finally, the geographical location of the institutions. Precarious situation was shown in respect of the items analyzed, but a trend to little better results was also shown according to the bigger size of the hospitals, as well as with hospitals with teaching fields activities and philanthropic hospitals, despite being public or private as far as financial management is concerned. The presence of an executive group for controlling hospital infection was a differential element. The second stage of the research includes an observational study in which the incorporation by professionals of biosafeness measures during the venous punctures procedures were analyzed in three hospital services. Professionals here were doctors and registered and no registered nurses. Differences were observed concerning to the adherence by the health care workers, among the hospitals and the sectors of the institutions concerning to the measures recommended during the development of the 
proceedings. However, the compliance of the professionals were modest in general, specially in relation to the hands washing, before and after the execution of techniques, and also the wearing of gloves. More promising results were seen with the dismissal of needles used and not recapping the instrument. In a cross analysis, the results of adherence to the latest ones were more promising in hospitals in which were better placed in the structural analysis. Opposite results were observed with the first measures (hands washing and gloves wearing). Professional's adherence to hands washing before and after the technique in focus, was shown more frequent with the treatment of children whereas the immediate dismissal and not recapping needles was more frequent with adults. It was shown there is also a trend that female professionals adhere more to the hands washing after the proceedings in focus than the male ones. Professional's adherence towards the safety measures is also different when the period of being graduated is taken into account. Professionals who were graduated from five to ten years ago show more compliance to safety measures when compared to those graduated in a shorter or longer period respectively. In the third stage, the awareness towards the self preservation/ contamination of professionals was analyzed using Collective Subject Speech technique. Professionals were also limited to doctors, registered and no registered nurses, during this stage. We analyzed that the professional's speeches evoked, mainly, perceptions that they act under biological risks, chiefly blood transmitted viruses with emphasis on the HIV and HBVs in minor scale. Professionals were aware that they seek self-protection principally by the use of protective equipment but they know that they are subject to structural institutional constraints in the places they act as far as self protection is concerned. The analysis of produced speeches indicates that the repertoire presented by the professionals portray the structural precariousness practically generalized in hospitals related to biosafeness. The subject's social representation about the biosafeness issue, marked by a dose of alienation, might also have influence such structures. The findings, seen in a conjuncture, allow us to deduct, that for construction of a suitable biosafeness apparatus, structural elements and elements related to the different work process, as well as details related to the human praxis concur. As recommendations, we emphasize that efforts are to be taken in a way that biosafeness permeates a new manner of thinking and acting in health. The schools 
which form human resources in health must incorporates the issue in focus in the teaching contents; the health services, hospitals principally, should not neglect the in service education of their professionals concerning to the biosafeness and finally, the people in charge of public policies, must pay attention to the analysis of the quality of public health services taking into account the health of their own professionals.

Key terms: Biosafeness, hospitals, health care workers. 


\section{LISTA DE TABELAS}

Tabela 01 Caracterização dos hospitais estudados. Itabuna - BA, 2001

Tabela 02 Distribuição das CCIHs dos hospitais sob estudo de acordo com o tempo decorrido de sua implantação. Itabuna-BA, 2001

Tabela 03 Profissionais presentes nas composições das CCIHs dos hospitais estudados. Itabuna-BA, 2001

Tabela 04 Atividades desenvolvidas pelos enfermeiros das $\mathrm{CCIH}$ existentes nos hospitais sob estudo. Itabuna-BA, 2001

Tabela 05 Número e percentual de hospitais de acordo com a Presença das características pesquisadas, relativas à estrutura de biossegurança. Itabuna-BA, 2001

Tabela 06 Presença de itens relativos à biossegurança nos hospitais, de acordo com características institucionais: Porte, Vinculação administrativo-financeira, Categoria. Localização geográfica, constituir-se em Campo de Ensino e Presença de $\mathrm{CCIH}$. Itabuna - 2001

Tabela 07 Porcentagem de itens presentes - existência de infraestrutura, normas e rotinas para biossegurança para agentes biológicos em cada um dos hospitais. Itabuna-BA, 2001

Tabela 08 Adesão às práticas de auto-proteção em procedimentos de acesso venoso de pacientes, por profissionais de saúde, em três hospitais da cidade de Itabuna. Itabuna-Ba, 2002

Tabela 09 Adesão às práticas de auto-proteção em procedimentos de acesso venoso de pacientes, por profissionais da saúde, em três hospitais da cidade de Itabuna, de acordo com diferentes setores hospitalares. Itabuna -Ba, 2002

Tabela 10 Aderência a práticas de auto-proteção envolvidas nos procedimentos de punção venosa nos diferentes setores dos hospitais estudados. Itabuna-Ba. 2002.

Tabela 11 Aderência a práticas de auto-proteção envolvidas em procedimento de punções venosas, por diferentes categorias profissionais em hospitais da cidade de Itabuna. Itabuna-Ba.2002..

Tabela 12 Procedimentos envolvendo o emprego de medidas de autoproteção de acordo com o conhecimento ou não do diagnóstico do paciente, condição de execução do procedimento (Rotina/Urgência), tipo de remuneração hospitalar pelo atendimento em hospitais da cidade de Itabuna. Itabuna-Ba. 2002.

Tabela 13 Procedimentos realizados por profissionais de hospitais da cidade de Itabuna envolvendo o emprego de medidas de auto-proteção de acordo com a faixa etária dos pacientes. Itabuna-Ba. 2002. 


\section{LISTA DE FIGURAS}

Figura 01 Mapa da região de subjurisdição da sétima Diretoria Regional de Saúde da Bahia

Figura 02 Dispersão dos hospitais agrupados por porte - Itabuna-Ba, 2001...

Figura 03 Dispersão dos hospitais agrupados conforme vinculação administrativa/status financeiro. Itabuna-BA. 2001

Figura 04 Dispersão dos hospitais agrupados conforme tipo de atendimento geral ou especializado. Itabuna-BA. 2001.

Figura 05 Dispersão dos hospitais agrupados conforme tipo de clientela atendido. Itabuna-BA, 2001

Figura 06 Dispersão dos hospitais agrupados conforme corpo clínico aberto/fechado. Itabuna-2001

Figura 07 Dispersão dos hospitais agrupados conforme localização geográfica. Itabuna-BA. 2001

Figura 08 Dispersão dos hospitais agrupados conforme constituição enquanto campo de ensino. Itabuna-Ba, 2002.

Figura 09 Dispersão dos hospitais agrupados conforme existência de comissão de controle de infecção hospitalar. Itabuna -Ba, 2002.....

Figura 10 Dispersão dos hospitais agrupados conforme existência de grupo executor de controle de infecção hospitalar. Itabuna-Ba. 2002. 


\section{ÍNDICE}

\section{RESUMO}

\section{SUMMARY}

\section{LISTA DE TABELAS}

\section{LISTA DE FIGURAS}

\section{INTRODUÇÃO}

1.1 Histórico: dos hospitais das infecções, dos isolamentos, das precauções com infecções nas instituições hospitalares................................

1.2 Delimitação do problema de pesquisa/justificativa............................................ 13

2 OBJETIVOS

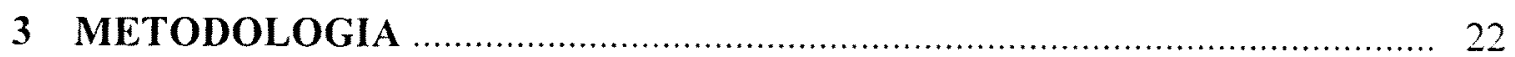

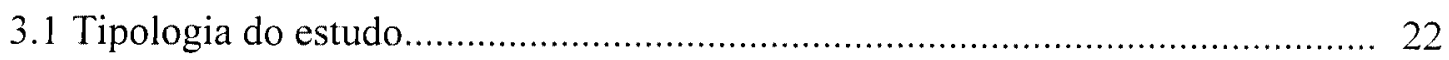

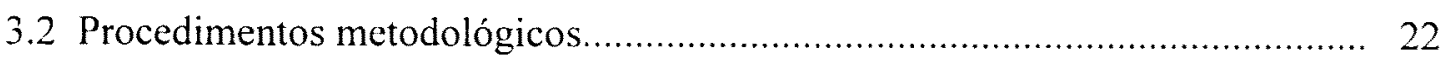

3.2.1 Descrição da estrutura dos serviços hospitalares relativa à biossegurança...... 22

3.2.1.1 Instrumento para coleta de dados.......................................................... 26

3.2.1.2 Tratamento estatístico dos dados............................................................. 28



3.2.2.1 Instrumento para coleta de dados............................................................. 31

3.2.2.2 Tratamento estatístico dos dados............................................................... 31

3.2.3 Estudo das percepções dos profissionais acerca de temas relativos à

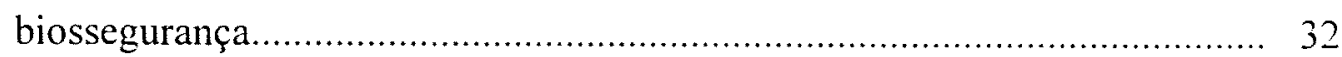

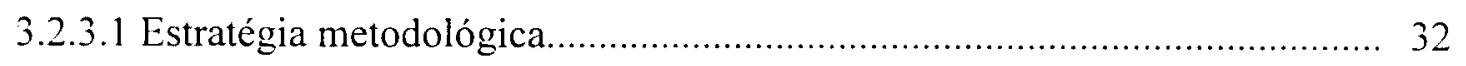

3.2.3.2 Organização dos dados............................................................................. 33

3.2.3.3 População e amostra (Os sujeitos da pesquisa).......................................... 33

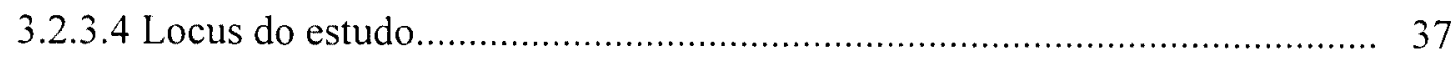

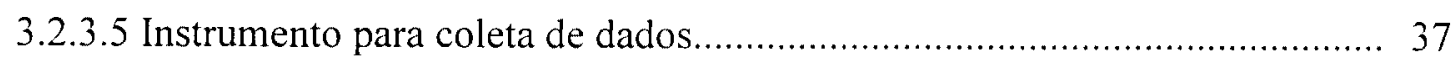

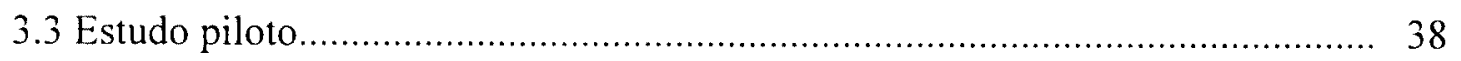


4.1 Infra-estrutura Organizacional. 42

4.1.1 Caracterização das CCIHs e das CIPAs.

4.2.2 Presença de normas, treinamentos, registros, rotinas e infra-estrutura física relativos à biossegurança.

4.2.3 Os hospitais de acordo com a presença do conjunto geral de itens considerados para fins do estudo.

5.1 Infra-estrutura organizacional dos hospitais, nos aspectos relativos à biossegurança - As comissões de controle de infecções e as comissões internas de prevenção de acidentes.

5.2 Presença de normas escritas acerca de biossegurança 68

5.3 Realização de treinamentos para normas de biossegurança. 77

5.4 Realização de registros concernentes à biossegurança. 84

5.5 Atenção médica admissional e rotinas de imunização profissional..... 91

5.6 Isolamento de pacientes.

5.7 Desempenho geral dos hospitais quanto à presença dos conjuntos de itens considerados para fins de análise da estrutura concernente à biossegurança nas atividades assistenciais

6 RESULTADOS - ESTUdO DO PROCESSO DE TRABALHO - ADESÃO Às PRÁTICAS DE AUTO-PROTEÇÃO ENVOLVIDAS NAS PUNÇŌES VENOSAS. 
8 AS PERCEPÇÕES DOS PROFISSIONAIS ACERCA DO CONTAMINARSE E PRESERVAR-SE

8.1 Sobre o risco de contaminar-se/contagiar-se.............................................. 142

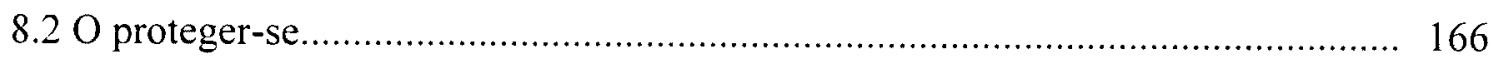

8.3 Significado do proteger-se na ótica dos entrevistados................................ 201

8.4 As reações frente à possibilidade de contágio/contaminação.............................. 210

8.5 Sobre o medo de se contaminar/contagiar.................................................. 228

8.6 Sobre os significados da biossegurança.................................................... 243



10 REFERÊNCIAS BIBLIOGRÁFICAS ....................................................... 259

ANEXOS 


\section{INTRODUÇÃO}

\subsection{Histórico: dos hospitais, das infecçōes, dos isolamentos, das precauções com infecções nas instituições hospitalares.}

Iniciamos a apresentação do tema maior de nossa investigação - o cenário da biossegurança nas atividades assistenciais em hospitais, com um breve histórico dessa instituição desde há muito presente na vida das comunidades - os nosocômios.

As primeiras referências à sua existência remontam ao ano 325, quando bispos, reunidos no concílio de Nicéia, foram instruidos a construí-los ao lado de toda a catedral. Nessa época a medicina estava relacionada com o caráter religioso e mágico. Fomentava a criação dos nosocômios além da desejada inspiração espiritual a conferência de algum conforto ao doente bem como o seu próprio isolamento da comunidade. (COUTO e NOGUEIRA 1997; OLIVEIRA 1997).

A idéia central era de que a presença do doente traz o temor de um perigo desconhecido e personifica em vivo a morte, tornando-se procedente, portanto, afastá-lo (OLIVEIRA 1997).

Como outras instituiçôes que surgiram simultaneamente em vários continentes e lugares do mundo antigo, não se pode identificar uma origem única do hospital. Ele já existia na Grécia de Esculápio e na Roma antiga, onde vários templos criados para homenagear esse sábio Deus serviam de abrigo aos pobres, velhos e enfermos. $\mathrm{Na}$ China, no Ceilão, no Egito, antes e depois de Cristo, há registros de hospedarias, hospitais e hospícios, palavras que têm a mesma raiz latina. Nesses lugares, almas pias patrocinavam e cuidavam de peregrinos, crianças e velhos (RIBEIRO 1993).

$\mathrm{Na}$ idade média, a organização hospitalar tinha, no seu âmago, também o afastamento do doente do convívio com os demais. Objetivava, pois, liberar a sociedade das doenças e dos contágios e ao mesmo tempo servir como prisão para os agitadores da ordem civil, os vagabundos, os mendigos (ROSEN 1980). 
A atenção médica era pouco privilegiada. Nas instituições, trabalhavam pessoas com funções caritativas, religiosos ou leigos "mais preocupados em salvar a própria alma" (OLIVEIRA 1997).

As idéias sobre infecção e contágio praticamente inexistiam. Fracastoro (1478-1553) foi quem primeiro postulou um conceito de infecção, na obra De Contagione et Contagosis Morbis. Referiu-se às formas de contágio direto, indireto e à distância. Descreveu doenças epidêmicas e aventou a possibilidade da sua veiculação pelo ar, o que contribuiu para um certo impulso no estudo sobre transmissão de doenças (SILVA et al. 2000).

As infecções hospitalares, embora obviamente sem essa denominação, desde sempre fizeram parte do hospital. A ocorrência era certamente muito alta devido, principalmente, à elevada prevalência de doenças epidêmicas na comunidade e, também, às precárias condições higiênicas dentro dos hospitais (WIPPLE 1961).

Demonstrativo da problemática das infecçôes era contumaz que operados jazessem uns ao lado dos outros envolvidos em ataduras mal cheirosas, emplastradas de pus. Era a chamada febre purulenta, febre traumática, mal misterioso e inevitável. O número de mortes era elevadíssimo, os quartos e enfermarias dos hospitais exalavam um cheiro nauseabundo (MELLO 1980).

As mudanças econômicas e sociais trazidas com o fim do feudalismo e com o advento do mercantilismo, dentre as quais a maior importância conferida às municipalidades para o equacionamento dos problemas comunitários e o interesse progressivo de subordinar o clero às autoridades civis, impuseram gradativa mudança aos hospitais do ocidente. Com a criação dos Estados monárquicos, essas instituições passaram à responsabilidade da administração pública e o médico começou a se tornar sua figura central e a simbolizá-la (RIBEIRO 1993).

Com as devidas ressalvas, essa trajetória política e social do hospital europeu teve continuidade nas colônias. A presença e intervenção do Estado no hospital colonial foi, contudo, bastante modesta, cabendo à comunidade, por exemplo, no continente americano, a iniciativa de construí-lo, dirigi-lo e sustentá-lo (RIBEIRO 1993). 
Os hospitais eram todos muito precários, com excesso de doentes, más condições higiênicas, conferindo, por isso, grandes riscos; o pessoal era em pequeno número e pouco qualificado; e o trabalho, grosso modo, ainda era entendido como caridade e penitência (RIBEIRO 1993).

A partir do século XVII, todavia, começando na Holanda, o hospital tornou-se além de campo das práticas médicas, instrumento de formação e de aperfeiçoamento, ainda que a assistência seguisse com bastante precariedade (RIBEIRO 1993).

Durante séculos, os doentes eram tratados sem separação quanto a nosologia. Conviviam, lado a lado, pacientes em recuperação com pacientes terminais. As doenças infecciosas disseminavam-se com rapidez prodigiosa. Não raro, o paciente era admitido com determinada afecção e vinha a falecer de cólera ou febre tifóide (COUTO e NOGUEIRA 1997).

A febre puerperal grassava em grande número de mulheres que tinham seus partos realizados nos hospitais. Entre 1652 e 1862, ocorreram, por exemplo, 2000 epidemias da febre, sendo que a mais grave delas, iniciada em 1773, matou mais de um décimo das parturientes internadas nos hospitais da Europa (VIANNA 1983).

No final do século XVIII, com a Revolução Industrial, a construção de hospitais ganhou grande impulso, embora suas funções remetessem às antigas, ou seja, à assistência aos desvalidos e ao isolamento dos párias. Iniciaram-se, entretanto, os prenúncios da informação hospitalar (FOUCAULT 2002).

O hospital começou a aparecer ainda mais vinculado à figura médica e transpareceu a necessidade de uma observação sistemática e comparada dos hospitais e o aparecimento de uma disciplina hospitalar, bem como, o ajustamento do hospital ao esquadrinhamento sanitário da cidade, com adequação da sua estrutura interna, de modo que sua arquitetura passasse a ter importância para a cura das doenças. Há assim, um deslocamento do poder de um sentido religioso de salvação ou de assistência alimentar para de tratamento da doença e ocorre a implantação de um sistema de registro, acúmulo e formação de saber (FOUCAULT 2002). 
Campo fecundo de experiências diversas, o nosocômio passava a ter, paulatinamente, uma nova característica, a de incorporar tecnologias, a princípio artesanais e, nos séculos seguintes, industrialmente produzidas (RIBEIRO 1993).

As práticas médicas e de enfermagem, no entanto, bem como as próprias condições higiênicas seguiam pouco desenvolvidas. Como ilustração, em 1771, John Aikin, na França, observou a melhor evolução dos pacientes que possuíam leito próprio, ou seja, não o compartilhava com outro doente. Somente em 1793, a Convenção Francesa determinou que cada paciente tivesse sua própria cama, que deveria guardar uma distância mínima de três pés do leito ao lado (FERNANDES 2000). No maior hospital francês, o Hotel-Dieu, existiam, por exemplo, cinco mil pacientes para 2000 leitos. Também a título de ilustração, em 1771, na Inglaterra, foi dada ordem aos hospitais de Manchester para que todos os pacientes recebessem lençóis limpos à sua admissão, devendo ser trocados a cada três semanas.

Como demonstrativo da calamidade da época e do prenúncio da tomada do hospital como um campo de práticas para além da religiosidade, pode-se citar o fato de, em 1777, o rei Luís XVI, da França, nomear uma comissão para analisar a situação das instituições (FERNANDES 2000).

No relatório das atividades, a comissão registrou que morriam em média um para cada quatro doentes. E não eram apenas os pacientes que sucumbiam. Anualmente faleciam também $6 \%$ a $12 \%$ dos funcionários que aí labutavam, indistintamente, médicos ou pessoal auxiliar.

James Simpson, na Inglaterra, em meados do século XIX, registrou mortalidade relacionada à amputação quatro vezes maior em pacientes internados do que naqueles submetidos ao procedimento no domicilio. Realizou assim, um dos primeiros estudos de epidemiologia hospitalar, utilizando o termo "hospitalismo", para sugerir o risco relacionado aos cuidados hospitalares (COUTO e NOGUEIRA 1997).

Nesse cenário era comum, conforme citado, a mortalidade de mulheres em periodo puerperal, cujos partos se davam em hospitais. Em 1843, Oliver Wendell Holmes 
postulou que essas mortes decorriam de contaminação das parturientes pelos médicos e parteiras (COUTO e NOGUEIRA 1997).

Alguns anos depois Semmelweiss, médico húngaro, demonstraria a eficácia da lavagem das mãos na prevenção das infecções puerperais. Seu estudo iniciar-se-ia com a observação de diferenças significativas na incidência da doença entre duas clínicas obstétricas do Hospital de Viena. Na primeira unidade, onde os estudantes de medicina eram os responsáveis pela realização dos partos ocorria um grande número de infecções, enquanto numa segunda clínica, onde os procedimentos eram realizados somente por parteiras, a incidência era muito menor. O médico chegou, então, após descartar várias hipóteses, à conclusão de que na primeira clínica, os estudantes carregavam nas mãos (já que eram também responsáveis pela dissecação de cadáveres) "partículas cadavéricas" até às pacientes. Semmelweis determinou, então, em vista da descoberta, que todos os estudantes e médicos que fossem realizar algum exame ou procedimento nas pacientes lavassem as mãos com cal virgem clorada e novamente com água e sabão, entre os novos exames. Essa medida reduziu a mortalidade das puérperas por infecções de 12 a $24 \%$ para $2,38 \%$. Constatou-se, assim, a importância da transmissão cruzada, antes mesmo de se conhecer a existência dos microorganismos, verificação essa não aceita na época. A razão disso é de princípio ideológico: não se admitia que um médico pudesse ser agente causador de doença (OLIVEIRA 1997).

Semmelweis faleceria alguns anos depois, vitimado, de acordo com alguns historiadores, por infecção generalizada, atribuida como consequiência de acidente com lâmina de dissecção contaminada (FERNANDES 2000).

Não sem controvérsias, o acúmulo dos saberes e o aperfeiçoamento das práticas acabaram por lançar as bases para o hospital contemporâneo, que resultaram em uma série de inovações. Passaram a ser recomendados ambientes amplos, com ventilação e iluminação adequadas; os leitos coletivos foram proibidos; os enfermos passaram a ser divididos em categorias, de acordo com a natureza da sua enfermidade; cada pavilhão passou a ter seus próprios registros, onde se incluem os indicadores de mortalidade; estabeleceu-se um sistema de vigilância sobre as ações praticadas. 
Personagens importantes defenderam essa nova instituição mais limpa, mais arejada. Florence Nigthgale foi um bom exemplo. Ela teve o mérito de, por volta de 1850 , promover, na prática, importantes medidas para o controle das infecções hospitalares, sobretudo, daquelas que acometiam feridas cirúrgicas. Seus esforços puderam ser avaliados em relação à queda da mortalidade por infecções em ferimentos cirúrgicos, passando de $42 \%$ para $2 \%$, durante seu trabalho em Scutari, na guerra da Criméia (FERNANDEZ 1984).

No lastro das iniciativas de se controlar as doenças febris, foram construidos, ainda no século XIX. hospitais destinados exclusivamente a pacientes com febre, onde cuidados especiais eram tomados. A eficácia dessa iniciativa pôde ser constatada durante uma epidemia de febre tifóide em que de 1080 casos internados no London Fever Hospital, 27 casos foram adquiridos na instituição, contra 71 casos de 272 pacientes internados em hospitais gerais (FERNANDES 2000).

Mas nada foi tão fundamental para o controle das infecções, como as descobertas de Pasteur e Koch, no campo da microbiologia, no final do século XIX, com subseqüente derrocada da teoria Miasmática e da Geração Espontânea, já posta em dúvida por vários precursores da teoria microbiana. Com tais descobertas, iniciou-se, então, a era da bacteriologia (WIPPLE 1961).

Seguiram-se à descoberta da etiologia microbiana das infecções e da prevenção dessas doenças, outros conhecimentos não menos importantes como a comprovação do valor da anti-sepsia defendida por Lister, as bases da assepsia, a esterilização pelo vapor, de Von Bergman, em 1886; as luvas de borracha, por Halsted, em 1889; as máscaras cirúrgicas, por Von Mikulicz e Radeccki, em 1896, importantes medidas para o controle das infecções cirúrgicas (WIPPLE 1961).

Data de 1887, nos EUA, o aparecimento das primeiras recomendações publicadas em matéria de isolamento de pacientes com doenças contagiosas. Um manual hospitalar recomendava internar pacientes com essas doenças em acomodações separadas. Deflagrou-se. dai. a criação dos hospitais de doenças infecto/contagiosas e depois, no 
início do século vinte, passou-se a isolar, os pacientes com essas mesmas doenças dentro dos próprios hospitais gerais (AYUB et al. 2000).

O emprego de utensílios de uso individual e desinfetado foi intensificado. Os profissionais de saúde passaram a utilizar vestimentas de uso interno e exclusivo para o trato com esses pacientes. Tais procedimentos ficaram conhecidos como "barreiras de enfermagem".

A evolução dos isolamentos e a própria existência de instituições hospitalares exclusivas para doenças infecciosas seguiram, todavia, sob a influência da evolução dos antimicrobianos, assistida após as quatro primeiras décadas do século XX.

Ressalte-se que o hospital que emergiu nesse século ainda era um lugar de internação de pobres, embora todos reconhecidamente doentes e carecendo de cuidados médicos. Pessoas ricas passaram a utilizá-lo à medida que acomodações diferenciadas vieram a ser instaladas e somente após sensivel queda da mortalidade por infecção intra-hospitalar (RIBEIRO 1993). Com efeito, com a disponibilidade dos antibióticos, principalmente a penicilina, a partir de 1941, tornou-se possível uma luta mais efetiva contra as infecções e o próprio quadro afeto a essas infecções nos hospitais sofreu melhoras.

Observe-se que o hospital perdera as missões de penitência e misericórdia da idade média e tornara-se, definitivamente, um lugar de tratamento e de recuperação, com a incorporação do cientificismo da medicina, a partir do século XVIII. Mas, somente no século $\mathrm{XX}$, com a produção industrial dos quimioterápicos e de equipamentos, adquiriu características e missões novas, próprias do hospital contemporâneo.

Como conseqüência do melhor controle das infecções bacterianas, fecharam-se, na década de 50. as instituiçōes hospitalares exclusivas para doenças infecciosas. Por volta de 1960, cerraram-se aquelas dirigidas para tuberculosos e esses pacientes passaram a ser internados, quando necessário, em hospitais gerais (APCIH 1999; SILVA et al. 2000). 
As infecções por bactérias parecem, a um certo momento do século $\mathrm{XX}$, um problema sob controle. Entretanto fatores como o uso indiscriminado dos antimicrobianos, um certo negligenciamento nas técnicas assépticas e sutis modificações que começaram a se processar nas características dos pacientes atendidos, cabendo destacar a maior sobrevivência de prematuros, idosos e portadores de doenças de maior gravidade, permitiriam que, em pouco tempo, se constatasse que o problema da ocorrência de infecções nos hospitais adquiriu novos contornos, com o aparecimento de cepas cada vez mais resistentes aos produtos surgidos no mercado.

Surtos de infecções por staphylococcus resistentes à penicilina, a partir da década de 50, nos hospitais da Europa, vieram despertar o interesse dos profissionais da saúde especificamente para o controle das infecções hospitalares. A transmissão de infecção entre pacientes passou a ser reconhecida como uma séria conseqüência da internação (SILVA et al. 2000).

Desencadeou-se, com isso, a criação de Comissões de Controle de Infecções Hospitalares, cujas funções recaem sobre a vigilância epidemiológica das infecções, sobre a determinação de normas e rotinas para sua prevenção e sobre a atuação na educação continuada dos profissionais de saúde. Nesse contexto nos Estados Unidos, em 1960, pesquisadores do CDC (Centers for Disease Control and Prevention), investigando surto de infecção nosocomial, despertaram para a necessidade de política padronizada para isolamento de pacientes hospitalizados com doenças transmissiveis. Em vista disso, publicaram em 1970, o Isolation Techniques for Use in Hospitals e, em 1975, revisão desse manual. Com tais publicações introduziu-se o conceito de isolamento por categorias (isolamento estrito, respiratório, de proteção, entérico, precauções com sangue e com materiais descartáveis) (CDC 1975).

Tais recomendações mostraram-se ineficientes, uma vez que os isolamentos foram determinados, não se valorizando adequadamente suas vias de transmissão. Como todas as doenças agrupadas numa mesma categoria de isolamento podem possuir características epidemiológicas diversas, algumas requereriam precauções de 
isolamento menos complexas que outras, resultando, muitas vezes, em isolamento excessivo e vice-versa (SILVA et al. 2000).

O inicio da década de 80 , no mesmo país, foi marcado por uma nova situação na infecção hospitalar, com a ocorrência de infecções por microorganismos resistentes a múltiplas drogas e pela identificação de novos agentes associados à infecção. Deflagrou-se, a partir daí, a necessidade de um sistema de isolamento mais direcionado para patógenos de transmissão nosocomial (SILVA et al. 2000).

Nesse contexto, foi publicado, em 1983, pelo CDC, o Guideline for Isolation Precautions in Hospitals, em substituição ao manual de 1975. Sua principal característica foi a valorização do tipo de isolamento por parte do corpo clínico hospitalar. As recomendações indicavam a necessidade de que as decisões fossem tomadas em vários níveis, cabendo aos órgãos responsáveis pelo controle das infecções hospitalares (CCIHs) determinar se o isolamento seria relacionado por categoria ou por doença especifica. O profissional responsável pelo isolamento de um determinado paciente passou a decidir sobre as precauções individuais a serem implementadas e a estipular a necessidade do uso de equipamentos de proteção individual (EPI), como aventais, máscaras e/ou luvas, baseados no tipo de exposição a materiais contaminados (GARNER e SIMMONS 1983).

De acordo com o mesmo manual de 1983 a antiga categoria denominada precauções com sangue primariamente direcionada para pacientes com hepatite tipo B foi renomeada como precauções com sangue e fluidos orgânicos, incluindo, assim, cuidados com o HIV. O isolamento por doenças específicas deveria se limitar ao emprego de medidas minimamente necessárias à transmissão da infecção.

Como conseqüência, tem-se que, de um lado, restringe-se o isolamento excessivo, e, por outro, situações como a ocorrência de doenças não usuais em alguns hospitais, o atraso e até mesmo um equívoco diagnóstico poderiam colocar em risco outros pacientes e o próprio profissional de saúde (SILVA et al. 2000). Deduz-se, então, a necessidade de maior treinamento dos profissionais e de um sistema hospitalar informatizado e com boa acurácia diagnóstica. 
Note-se que a evolução do controle das infecções e, conseqüentemente, das próprias medidas de precauções e isolamento correu em paralelo ao alcance, pela medicina, nas últimas décadas, de uma eficácia inimaginável, se bem que de acesso limitado. A medicina agora pode coibir a dor, o sofrimento e a morte, por meio de um saber e de uma experiência nunca antes vista de suas equipes de tecnólogos (não mais da ação individual do médico) que se escondem, quase anônimos, atrás de máquinas e máscaras, e do hospital (RIBEIRO 1993).

A percepção da imprescindibilidade social desse último é praticamente absoluta. A segurança de sua eficácia quase materializável, a solidariedade intrínseca entre os pares nele atuantes, a autoridade incontestável e a onipotência, são algumas de suas características (RIBEIRO 1993).

Esse hospital tem, assim, missões que são herdadas da sua etapa precedente e outras que são mais recentes. Além disso, continua sendo um aparelho formador de profissionais em permanente qualificação, independente de ser stricto sensu, uma escola. Ao qualificar técnicos, ele, simultaneamente, qualifica e avaliza tecnologias produtos industriais, mercadorias. Ademais é também uma empresa, independentemente de seu caráter jurídico administrativo, visto que realiza uma atividade econômica, já que é lugar de venda e consumo das tecnologias médicas (RIBEIRO 1993).

Pode-se dizer que o hospital atual não é apenas uma instituição que evoluiu. É muito mais, é uma instituição nova. Mudaram suas características, suas finalidades, sua administração, seus sujeitos, seus instrumentos e processos de trabalho, ainda que diferenças qualitativas e de acesso mantenham-se intra e extra territorialmente (RIBEIRO 1993).

Especificamente sobre os aspectos da problemática das infecções, malgrado as instituições tenham investido mais nos acometimentos de pacientes, face a seu caráter indubitavelmente iatrogênico, de alta representação numérica e de custos adicionais aos próprios serviços nos países desenvolvidos, e ao Estado, no caso do Brasil, é na década de 80, com o advento da AIDS, que são publicados estudos sobre 
a possibilidade de profissionais atuantes nas instituições hospitalares estarem sujeitos a riscos biológicos. Diversos trabalhos, principalmente americanos, salientam o risco da contaminação de profissionais pelo HIV, pelo espectro de doença fatal e da hepatite B pela alta incidência (MORGAN 1990; WELTMAN 1995).

Fomentado pelo crescimento da epidemia da AIDS, criou-se, em 1985, pelo CDC, o conceito de precauções universais, através de um aperfeiçoamento do Guideline for Isolation Precautions in Hospitals, de 1983 aqui já citado, com o objetivo de reduzir o risco ou transmissão de agentes infecciosos, principalmente veiculados pelo sangue, aos profissionais de saúde (CDC 1985, 1988).

Alternativas ao Guia de Isolamento de 1985, proposto pelo CDC, foram apresentadas. Dentre elas a de GILMORE et al. (1986), que propuseram um modelo simplificado que consiste no uso de equipamentos de proteção individual de acordo com classes numéricas. Distribuem-se, então, em Classe 1 - Uso obrigatório de luvas; Classe 2 - Uso de luvas e avental; Classe 3 - Uso obrigatório de luvas, avental e máscara; Classe 4 - Uso obrigatório de máscara. Outra alternativa provém dos departamentos de controle de infecções do centro médico de Harborview (Seattle) e da Universidade da Califórnia, que propõem um sistema denominado isolamento de substâncias corporais (ISC/Body Substance Isolation - BSI) (SILVA et al. 2000). Esse sistema propõe o isolamento de todas as substâncias corporais potencialmente infectadas (sangue, fezes, urina, escarro, saliva, secreção de feridas e outros fluidos orgânicos) de todos os pacientes a despeito de sua doença de base ou infectividade, através do uso principal de luvas. O sistema enfatiza o uso, em larga escala, de equipamentos de proteção individual, o que o torna impraticável na maioria dos hospitais, mesmo daqueles localizados em centros desenvolvidos, por conta dos seus custos. Além disso, o método não trata de isolamentos para algumas doenças específicas, como, por exemplo, aquelas de transmissão aérea, como a tuberculose.

No início dos anos 90, não havia consenso nos hospitais norte americanos referente ao emprego de isolamentos e medidas de proteção. Ocorreu muita variação na interpretação e uso das Precauções Universais (PU) e do Isolamento de Substâncias Corporais (ISC), evidenciando-se a necessidade de uma diretriz. 
Publicou-se, então, em 1996, pelo CDC, um novo manual, que resume elementos razoavelmente exeqüiveis das Precauções Universais e do próprio ISC, em um conjunto único de precauções denominadas Precauções Padrão (PP), a serem aplicadas ao atendimento de todos os pacientes hospitalizados, independentemente de seu estado presumível de infecção.

As precauções padrão, segundo o manual, deveriam ser utilizadas quando existisse o risco de contato com sangue, todos os fluídos corpóreos, secreções e excreções com exceção do suor, da pele com solução de continuidade e mucosas. O manual estabeleceu também precauções especificas, indicadas para o uso durante o contato com pacientes suspeitos ou sabidamente infectados/colonizados por patógenos transmissiveis e epidemiologicamente importantes (GARNER 1996).

Particularmente após o advento da AIDS, ocorreu uma modificação do raciocínio de proteção anticontágio intra-hospitalar. Até então, os isolamentos e o conjunto de cuidados tomados com os acometimentos infecciosos tinham suas bases fundamentadas principalmente na proteção da comunidade do risco. Com a epidemia da doença em tela. houve um deslocamento das práticas preponderantemente de proteção da comunidade para uma prática de proteção com ênfase também no profissional de saúde, pois o doente é um risco para os que o rodeiam na sociedade (sem se entrar aqui em profundas discussões sociais e éticas do risco) e para os que dele cuidam.

As precauções universais posteriormente aperfeiçoadas pelas precauções padrão não só fortalecem o conceito de "Self protection", como universalizam o risco: consideram todo e qualquer paciente como fonte potencial de contaminação.

No lastro da mesma epidemia, a partir da década de 90 , com o recrudescimento da tuberculose no mundo, acompanhado da emergência de cepas de mycobacterium tuberculosis resistentes a múltiplas drogas, especialmente em áreas de alta prevalência da infecção pelo HIV, associada à hospitalização freqüente desses pacientes, delineou-se a possibilidade de ocorrência de surtos intra-hospitalares da doença, com transmissão entre pacientes e dos doentes para os profissionais da 
saúde, configurando um novo enfoque sobre a patologia, de particular importância também sob o ponto de vista ocupacional .

Publicam-se pelo CDC normatizações afetas à área com fins de controlar a problemática em hospitais norte americanos (CDC 1989, 1994).

No Brasil, no final da década de 80 , também sob a influência da epidemia da AIDS, foi que as preocupações com a exposição no trabalho hospitalar aos agentes infecciosos começaram a tomar corpo, incluindo-se ações de vigilância desenvolvidas pelas secretarias de saúde de alguns municípios e Estados, através de programas de saúde do trabalhador. Predominaram as ações dirigidas ao controle $\mathrm{e}$ prevenção da AIDS e da hepatite $\mathrm{B}$, decorrentes dos acidentes de trabalho com material pérfuro-cortante. Quanto às medidas de precauções, estas assentaram-se nas produções norte americanas relativas ao assunto, particularmente às publicações do CDC (APCIH 1999; BAHIA 1996).

As recomendações para prevenção especificamente da transmissão intra-hospitalar da tuberculose começaram, por outro lado, a ser incorporadas mais recentemente no País, alavancadas, em particular, a partir das prescrições do I Consenso Brasileiro de Tuberculose, de 1997. que indicou ações de Prevenção e Biossegurança, constituindo-se em um conjunto de medidas administrativas e de controle ambiental, incluindo-se aspectos de infra-estrutura e de normas para a proteção contra agentes de veiculação respiratória ou por aerossol. (BRASIL 1997).

\subsection{Delimitação do problema de pesquisa/justificativa}

Em que pesem a conhecida variação qualitativa das instituições hospitalares nacionais e das suas demandas especificas e, ainda, a ausência de um modelo de avaliação institucional do hospital que leve em conta suas características enquanto meio seguro de atuação profissional frente à problemática dos riscos biológicos, propõe-se aqui a estudar a dimensão do problema que vem sob o grande título de biossegurança. 
Biossegurança é entendida como o conjunto de normas e procedimentos considerados seguros e adequados à manutenção da saúde, em atividades de risco de aquisição de doenças profissionais. Antes de uma disciplina em sentido estrito, é um campo de realização de práticas técnicas e sociais destinadas à conhecer e controlar os riscos que o trabalho em saúde pode aportar ao meio e à vida (TEIXEIRA e VALLE 1998). Práticas essas que dependem de uma série de fatores que vão de elementos conjunturais e estruturais até a integração do trabalhador, não obstante sujeito aos reveses das estruturas sociais nas quais encontra-se inserido, ainda assim sujeito no seu ambiente de trabalho.

A análise da estrutura de apoio à implementação das medidas de biossegurança nos hospitais reveste-se, desta forma, de indubitável importância, posto que é ela que permite um alicerce mínimo sobre o qual são construídas as práticas. Também o é o estudo de aspectos do processo de trabalho envolvidos na praxis da auto-proteção.

E ainda, os discursos dos profissionais acerca do contaminar-se/preservar-se porque a incorporação de mudanças depende fundamentalmente dos valores atribuídos à problemática da biossegurança por esses mesmos profissionais.

Levando-se em conta que se vislumbra, em última instância, a melhoria da qualidade da assistência prestada, não há como se pensar, correndo-se o risco de cair no senso comum, em melhorar a qualidade do atendimento, sem melhorar a qualidade do trabalho em saúde no seu mais amplo sentido.

$O$ fornecimento de cuidados de saúde satisfatórios, de maneira desejável tem obrigatória intersecção com a adoção de medidas de biossegurança, porque se assim não for, o cuidado poderá ser prestado sob uma plêiade de riscos para o profissional e, em subseqüência, também para o próprio usuário do serviço de saúde.

A qualidade do serviços de saúde pode ser analisada, segundo DONABEDIAN (1986), sob o ponto de vista da estrutura dos serviços, do processo de trabalho e dos resultados. O autor considera a estrutura como o aparelhamento físico, a conformação do quadro de recursos humanos, os aspectos organizacionais e administrativos das instituições de saúde; o processo como atividades específicas na 
prestação de cuidados e os resultados como os efeitos das ações na saúde do usuário e, como não incluir, na saúde do profissional prestador da assistência.

Justificam ainda nosso trabalho as diversas evidencias de que os profissionais atuantes na área da saúde e, particularmente em hospitais, estão sujeitos a adquirir infecções, denotando importância as hepatites B e C, a AIDS e a tuberculose, especialmente. As primeiras pelas incidencias que podem ser consideradas altas $\mathrm{e}$ subnotificadas; a AIDS pelo espectro de doença fatal e a tuberculose, por suas diversas consequêencias sobre a vida dos profissionais.

Para o HIV, a possibilidade de contaminação dos trabalhadores expostos tem sido estimada em 0,28 a $0,3 \%$ nos acidentes pérfuro-cortantes e de $0,06 \%$ nas exposições muco-cutâneas (FITCH 1993).

Quanto ao HBV (Hepatite B), os mesmos tipos de exposição apresentam risco de contaminação de $2 \%$ a $40 \%$, na dependência da concentração de partículas virais no material contaminante (ROZENBAUM 1998). A hepatite B é reconhecida como um problema de saúde mundial e preocupante pela tendencia a se cronificar com complicações graves, como a cirrose e o câncer hepático e não raro a morte (CERVANTES 1996). Como ilustração destaca-se que mais de 5.000 trabalhadores do setor saúde nos Estados Unidos se infectam com o virus da hepatite B anualmente (WELTMAN et al. 1995).

Estatísticas nacionais a respeito não foram encontradas na literatura consultada .

No que concerne ao $\mathrm{HCV}$, o risco de aquisição após exposição percutânea é estimado entre $3 \%$ a $10 \%$ (KOZIOL e HENDERSON 1999). A possibilidade de complicações na evolução da doença é quatro a dez vezes maior que para o HBV(Hepatite B). Cerca de $30 \%$ a $70 \%$ dos infectados podem evoluir para a cronicidade e o fator agravante da aquisição profissional deste vírus recai sobre a ausência de vacinas e de outros imunobiológicos (GERBERDING 1995).

A tuberculose, por outro lado, caracterizada como uma doença de estreita relação com condições sócio-econômicas precárias, de fácil disseminação em ambientes com aglomeraçòes, vem assumindo novos contornos em função do seu recrudescimento e 
aparecimento de bacilos multirresistentes. $\mathrm{O}$ resultado é um aumento na incidência de doentes em fase bacilifera nos estabelecimentos de saúde do mundo e não diferentemente no Brasil. Grande parte dos casos está associado à expansão da epidemia da AIDS e da presença de co-morbidades e fatores de risco, elementos de importância no que diz respeito à sua ocorrência no ambiente hospitalar (PENTEADO 1999).

Diferentes pesquisas sobre o assunto podem ser citadas. Por exemplo, investigando a tuberculose em hospitais, o Centers for Disease Control and Prevention - CDC relata vários surtos hospitalares causados por bacilos multirresistentes (MDR); nesses surtos, observa-se a contaminação de pacientes, além da preocupante possibilidade de contaminação de profissionais da saúde (CDC1994). Outro dado que pode ser referenciado diz respeito à inquérito epidemiológico realizado em 1992, em hospitais americanos, em que se verificou que em um, de cada oito hospitais, havia pelo menos um profissional de saúde que adquiriu tuberculose hospitalar naquele ano (BRITO 1998).

Estudo inglês de MEREDITH et al. (1996) revela que a notificação de casos de tuberculose em profissionais da saúde é de duas a três vezes maior, quando comparada a profissões de nível sócio-econômico similar. Ressaltam os autores, todavia, que os achados, por si, não permitem, em tese, afirmar que os profissionais estão necessariamente em maior risco de aquisição da doença, face a possível viés desses profissionais notificarem mais a doença que os demais. Ressaltam, contudo, que numa análise cruzada com estudos que tratam de notificações de seus próprios agravos por parte desta mesma classe. os resultados sugerem fortemente que os profissionais encontram-se em risco aumentado para a doença.

Por fim. pesquisas nacionais recentes demonstraram a presença de infecção e adoecimento de profissionais de saúde e ainda comprovaram que o risco de aquisição da doença é significativamente superior para os referidos profissionais, chegando a freqüência dez vezes maior entre os profissionais de saúde do que na comunidade (PENTEADO1999). 
No que se refere às práticas de auto-proteção dos profissionais, os estudos demonstram, em sua maioria, uma baixa aderência às medidas preventivas. Problemática esta atribuída à falta de motivação e baixa percepção dos profissionais de saúde quanto aos riscos e importância da adesão às respectivas medidas.

Em trabalho realizado em uma unidade de emergência, nos Estados Unidos, por exemplo, verificou-se que apenas $50 \%$ dos profissionais usavam luvas para a realização de procedimentos invasivos como flebotomias e introdução de cateteres vasculares (LARSON e KRETZER 1995). Ainda nos Estados Unidos, investigação sobre a aderência de médicos residentes às precauções universais, identificou que as razões mais comuns para falhas nos procedimentos referem-se à falta de conhecimento, esquecimento e tempo insuficiente para executar medidas conforme o indicado (BECKER et al.1990).

Outro trabalho americano, agora sobre o uso de luvas para o contato com sangue e fluídos corpóreos, chegou à conclusão de que os profissionais não a consideravam necessárias. Algumas outras justificativas para o não uso de precauções referem-se à diminuição da habilidade, falta de prática para a utilização de luvas, posto que não foram treinados utilizando-as, e ainda de que o tipo de paciente atendido era considerado como de baixo risco para o HIV e HBV (HENRY et al. 1994).

Estudo desenvolvido em Hospital da cidade de São Paulo - Brasil demonstrou que $66,3 \%$ dos componentes da equipe de enfermagem desconheciam as denominadas, à época, precauções universais e 83,3\% não as utilizavam (SOUZA 1994).

Outras investigações, realizadas principalmente nos Estados Unidos, não detectaram diferenças nos níveis de aderência de funcionários que conhecem as normas quando comparadas com outros que as desconhecem (LARSON e KRETZER 1995).

Em revisão de literatura de dez anos sobre trabalhos americanos acerca de adesão de profissionais a medidas de prevenção de infecções hospitalares, registrou-se quinze estudos de intervenção com vistas ao aumento dos níveis de aderência dos profissionais de saúde. No entanto, nem todos se reportavam, a procedimentos de auto-proteção. Cinco testavam intervenções educacionais; em três estudavam-se 
práticas de feedback; em quatro, práticas educacionais e feedback; em um, mandato administrativo e em dois, melhorias tecnológicas. As intervenções educacionais sozinhas resultaram em maior conhecimento, mas tiveram efeito modesto na mudança de comportamento. De igual maneira, o feedback sozinho não se mostrou efetivo (LARSON e KRETZER 1995).

Um dos estudos correlaciona a auto-aderência, às precauções, utilizando os componentes do Health Belief Model (HBM). Esse modelo propõe que em um indivíduo, a propensão a um certo comportamento depende de alguns fatores: percepção individual de suscetibilidade à doença, percepção de severidade da doença, benefícios percebidos e obstáculos à prática do comportamento (LARSON e KRETZER 1995).

O fulcro dessa teoria é o de que, se as pessoas não aderem às precauções, elas ou não percebem muito o risco pessoal ou não consideram a doença de alta gravidade ou encontram obstáculos (custos, desconforto, tempo) para executar o procedimento. sendo esses tidos como muito grandes para superar o pretenso benefício.

Diversos autores confirmam que sem intervenções baseadas em teorias das ciências do comportamento, enfoques cognitivos, treinamento e avanços tecnológicos, dificilmente atitudes e comportamentos são modificados (KRETZER e LARSON 1998).

Ao que toca à estrutura relativa à biossegurança, por outro lado, há que se referir que nos Estados Unidos, desde 1987, a politica do Occupational Safety and Health Administration (OSHA) foi a de considerar os empregadores responsáveis pelas falhas na implantação das recomendações do $\mathrm{CDC}$, quando não oferecem um ambiente seguro e saudável aos trabalhadores. A OSHA tem autoridade legal e tornou obrigatório por decreto em 1992 o uso das precauções de proteção ao trabalhador da saúde, no que se refere aos riscos biológicos (DE FILLIPO et al.1992).

No Brasil, as regulamentações sobre a segurança do trabalho datam de 1978 e não tratam especificamente do trabalhador de saúde. Constam dessas regulamentações 28 
itens, dentre os quais cabem ser destacadas a Norma Regulamentadora n. ${ }^{\circ} 4\left(\mathrm{NR}_{4}\right)$ que regulamenta os serviços especializados em engenharia de segurança e medicina do trabalho (SESMT), com a finalidade de promover a saúde e proteger a integridade do trabalhador em seu local de trabalho; a $\mathrm{NR}_{5}$ que regulamenta a Comissão Interna de Prevenção de Acidentes (CIPA); a NR 6 os equipamentos de proteção individual (EPI), conceituados como todos os dispositivos de uso individual destinados à proteger a saúde e integridade física do trabalhador no local de trabalho; a NR7 a questão dos exames médicos; a NR 9 que estabelece o Programa de Prevenção de Riscos Ambientais que considera como agentes agressivos aqueles elementos que possam trazer ou ocasionar danos à saúde do trabalhador, em ambiente de trabalho, em função da natureza, concentração, intensidade e tempo de exposição ao agente (BRASIL 1978). Mais recentemente o Ministério da Saúde publicou as portarias 24 e 25 que atualizam, respectivamente, os textos da NR n. 7 tratando do Programa de Controle Médico de Saúde Ocupacional ( PCMSO), com o objetivo de promoção e preservação da saúde do conjunto dos trabalhadores nas empresas e a $\mathrm{NR}_{5}$ e $\mathrm{NR}_{9}$, na primeira incluindo a obrigatoriedade de elaboração de mapas de riscos por parte das empresas, como instrumento de atuação direta nos ambientes de trabalho e a segunda atualizando os conceitos de ambiente e riscos (BRASIL 1994a, 1994b).

Entretanto, não obstante recomendações de órgãos representativos da saúde do país, que se referem especificamente à biossegurança nos hospitais, e de iniciativas de algumas Secretarias Estaduais de Saúde, ainda não existem vigilâncias sistemáticas e específicas bem como a configuração de uma estrutura mínima que dê conta do cumprimento de medidas relativas à proteção dos profissionais contra os riscos biológicos na prática assistencial nas instituições hospitalares brasileiras.

Contudo, as preocupações emergentes com a biossegurança, e sua inclusão na visão geral da qualidade dos serviços não se constituem em um significado restrito. Fazem parte de uma tendência mundial, sustentada por uma mudança de paradigma cultural, pelo que se vem advogando e promovendo novos padrões de comportamento, diante das questões da preservação do meio ambiente, da própria vida e das relações externas à comunidade (TEIXEIRA e VALLE 1998). Além disso, entende-se que a existência de uma estrutura mínima relativa à biossegurança, nos hospitais, constitui- 
se em meio de se dimensionar a qualidade da assistência e as condições de trabalho dos profissionais da saúde.

Observe-se que os campos compreendidos pela biossegurança e pela gestão de qualidade estão unidos um ao outro, desde sua origem através do conceito de boas práticas (TEIXEIRA e VALLE 1998).

De acordo com CARDO (2000) boas práticas dependem de fatores sociais (construção, por exemplo, de formas de comportamento), fatores pessoais (que incluem valores individuais atribuídos às práticas pelo sujeito) e fatores ambientais (estrutura de apoio e tecnologia mínima disponível).

Nesse contexto, em que se vale destacar a relevância do tema - a biossegurança, justifica-se um trabalho que se propõe a estudar a configuração do cenário afeto à estrutura e ao processo de trabalho relacionados às medidas de proteção dos trabalhadores hospitalares concernentes aos riscos biológicos e ainda, os discursos dos profissionais sobre sua auto-proteção. 


\section{OBJETIVOS}

Descrever a organização de aspectos estruturais relativos à biossegurança nos hospitais sob a supervisão da Sétima Diretoria Regional de Saúde da Bahia ;

Verificar o grau de incorporação de práticas de auto-proteção (Biossegurança) por parte de profissionais atuantes em três hospitais, em procedimentos de punção venosa;

Analisar as percepções dos profissionais de saúde atuantes em hospitais acerca dos riscos concernentes aos agentes biológicos em seu trabalho e acerca do preservar-se. 


\section{METODOLOGIA}

\subsection{Tipologia do estudo}

Face às próprias características do estudo que toma o profissional da saúde enquanto sujeito e o hospital enquanto locus privilegiado de ações desses mesmos atores sociais, buscamos superar a dicotomia que aparta as pesquisas denominadas quantitativas daquelas nomeadas como qualitativas, integrando, neste trabalho, esses dois procedimentos metodológicos.

O estudo enseja assim três momentos. O primeiro constituindo-se em uma descrição das condições estruturais relativas à biossegurança nos hospitais (análise da estrutura, conforme as indicações de DONABEDIAN (1986), um outro da observação do como algumas práticas de auto-proteção que aqui delimitamos àquelas envolvidas nas técnicas de punções venosa são ou não incorporadas no dia a dia (análise do processo, segundo DONABEDIAN (1986) e, por último, na análise da percepção dos profissionais de saúde atuantes na prática assistencial acerca de aspectos concernentes aos supostos riscos biológicos a que estão submetidos bem como a aspectos de sua auto- proteção.

\subsection{Procedimentos metodológicos}

\subsubsection{Descrição da estrutura dos serviços hospitalares relativa à biossegurança.}

Esse momento da pesquisa constou de estudo descritivo empreendido nos hospitais localizados na área de abrangência da Sétima Diretoria Regional de Saúde da Bahia.

Para essa fase da pesquisa, utilizamos, então, como unidades elementares de análise, os hospitais relacionados à citada Diretoria Regional de Saúde (Sétima DIRES), responsável pela supervisão das ações de saúde de vinte e dois municípios, localizandose sua sede regional na cidade de Itabuna. 
A rede hospitalar em pauta constitui-se de vinte e sete instituições, nove delas localizadas no município polo (Itabuna), três na cidade de Camacan e as demais distribuídas uma para cada município nas cidades de Ibirapitanga, Ubatã, Gongogi, Ubaitaba, Aurelino Leal, Itapitanga, Coaraci, Itajuípe, Lomanto Júnior (Barro Preto), Ibicaraí, Floresta Azul, Buerarema, Jussari, Itajú do Colônia e Pau Brasil ( Figura 1). Os municipios de Maraú, Almadina, Itapé. Santa Cruz da Vitória e São José da Vitória. ainda que pertencentes do ponto de vista de jurisdição nos aspectos atinentes à saúde à sétima DIRES, não dispõem de unidades hospitalares.

No que se refere às características dos hospitais da região observa-se um predomínio, quanto ao número de leitos, de acordo com as normas e padrões de construções do Ministério da Saúde (BRASIL 1983), daqueles de pequeno (até cinqüenta leitos) e médio porte (de 51 a 150 leitos). em número de quinze $(55,5 \%)$ e dez $(37,0 \%)$, respectivamente. e somente dois hospitais grandes (acima de 150 leitos), ambos localizados na cidade de Itabuna $(7,4 \%)$, maior município em termos da geografia local.

Os hospitais gerais são também em maior número do que os especializados, vinte e três $(85,2 \%)$ e quatro $(14,8 \%)$, respectivamente. Os últimos. centram-se em duas maternidades, uma instituição pediátrica e um hospital destinado ao atendimento a pessoas com problemas de ordem psiquiátrica.

No que se refere à situação juridico-administrativa, há um predomínio das instituições públicas, treze hospitais $(48,1 \%)$, seguidas de hospitais privados, em número de oito $(29,6 \%)$ e seis filantrópicos $(22,2 \%)$. Os serviços hospitalares públicos, por sua vez, são na sua maioria, dez hospitais $(76,9 \%)$, vinculados ao poder municipal.

A maioria das instituições, dezessete $(63,0 \%)$. caracteriza-se pelo atendimento exclusivo à clientela cuja fonte de pagamentos pelos serviços recebidos recai sobre recursos provenientes de convênios com o Sistema Único de Saúde (SUS), seguidas das instituições que atendem também a usuários de convênios privados e pacientes particulares, nove $(33,3 \%)$, e, por último, uma única instituição $(3.7 \%)$ que circunscreve sua atenção no que se refere à internação, apenas a pacientes cujas fontes pagadoras são 
convênios privados e particulares. No que concerne ao corpo clínico, a maioria dos hospitais, vinte e quatro $(88,9 \%)$, dispõe de corpo clínico fechado.

Para a presente pesquisa, foram visitadas vinte e cinco das vinte e sete instituições existentes. Um dos serviços (localizado na cidade de Ibicaraí) foi excluído por encontrar-se, à época da coleta de dados, fechado para reformas e o segundo (localizado na cidade de Itabuna) por compreender instituição de atendimento psiquiátrico, cujas particularidades implicam na necessária elaboração de instrumentos de coleta de dados específicos, no que concerne ao controle de infecções e à biossegurança, o que, em conseqüência, não permite análises comparativas com outras modalidades hospitalares. (MILLWARD e THOMLINSON 1993)

Assim, no que se refere a categorização dos hospitais estudados, vinte e cinco, temos o seguinte quadro: quanto ao porte - quatorze hospitais de pequeno porte $(56,0 \%)$, nove de médio porte $(36,0 \%)$ e dois de grande porte $(8,0 \%)$; quanto a vinculação juridico financeira - doze públicos $(48,0 \%)$, sete privados $(28,0 \%)$ e seis filantrópicos $(24,0 \%)$; quanto a natureza do atendimento - vinte e dois gerais $(88,0 \%)$ e três especializados $(12,0 \%)$; quanto ao tipo de clientela atendida - somente pacientes cujas fontes de pagamento recaem exclusivamente sobre o SUS, dezesseis $(64,0 \%)$; somente pacientes particulares e provenientes de pagamentos via convênios privados, um (4,0\%); e todas as fontes de pagamento, oito $(32,0 \%)$; quanto ao corpo clínico, três hospitais $(12,0 \%)$ têm corpo clínico aberto e vinte e dois $(88,0 \%)$ têm corpo clínico fechado; dos vinte e cinco hospitais pesquisados, quatro (16,0\%) servem como campo formal de ensino para a área de saúde e vinte e um (84,0\%) não se prestam a esse tipo de atividade; quanto a localização geográfica, oito hospitais localizam-se na cidade de Itabuna(32,0\%) e dezessete nos demais municipios $(68,0 \%)$.

Segue, na seqüência, mapa regional onde estão localizados os serviços hospitalares relacionados à $7^{\mathrm{a}}$ DIRES. Na tabelal caracterizamos cada um dos hospitais visitados. 
FIGURA 1

Mapa da região de subjurisdição da Sétima Diretoria Regional de Saúde da Bahia. Itabuna-Ba, 2001.

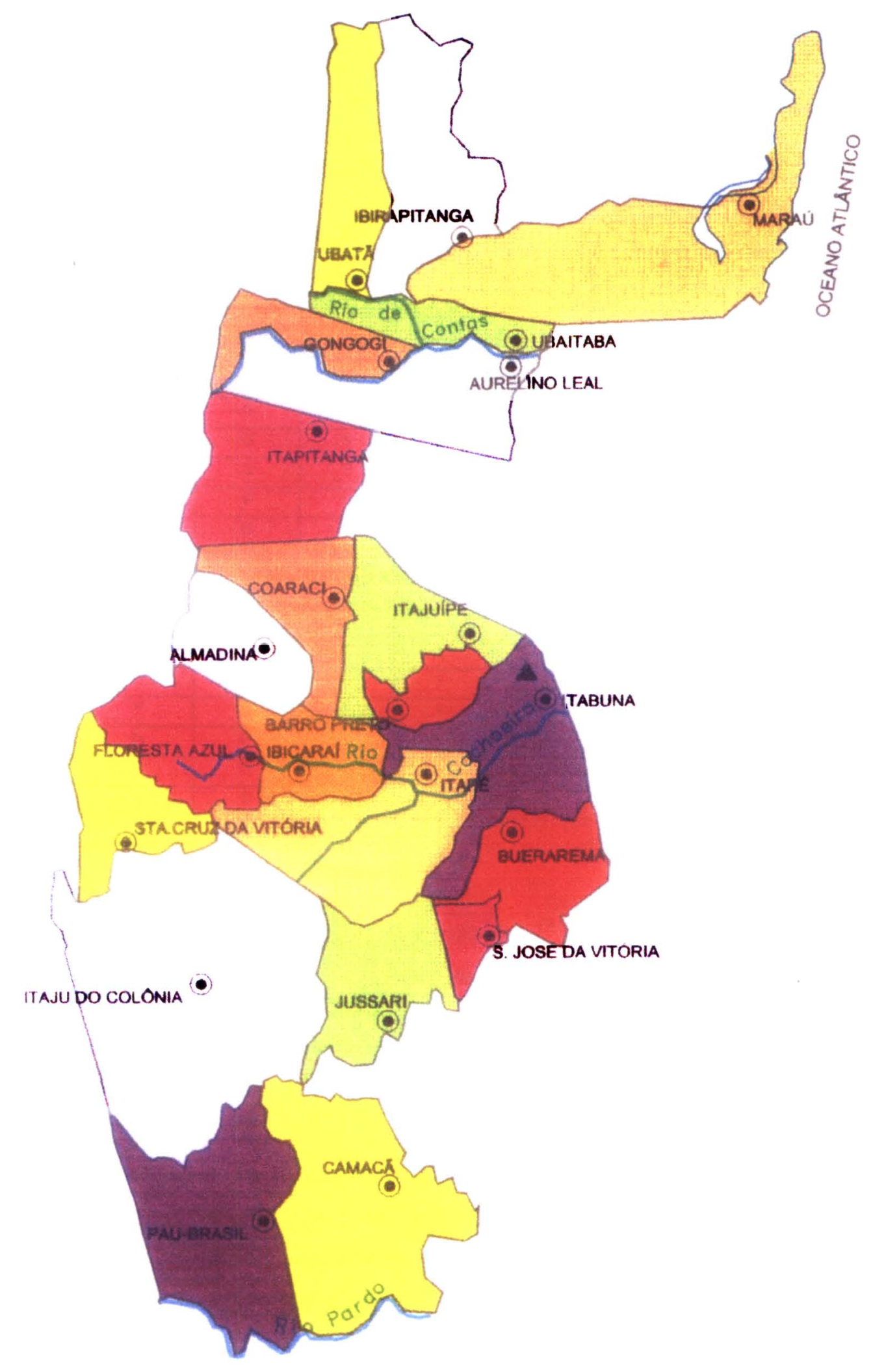

LEGENDA:

CIDADE

$(-$ 
Tabela 1 - Caracterização dos hospitais estudados. Itabuna - BA, 2001.

\begin{tabular}{|c|c|c|c|c|c|c|c|c|c|c|}
\hline Hospital & $\begin{array}{l}\text { Porte } / N^{\circ} \\
\text { de Leitos }\end{array}$ & $\begin{array}{c}\text { Vinculaçào } \\
\text { Adininistratival } \\
\text { Status }\end{array}$ & $\begin{array}{l}\text { Natureza do } \\
\text { atendimento }\end{array}$ & $\begin{array}{l}\text { Tipo de } \\
\text { clientela }\end{array}$ & $\begin{array}{l}\text { Predominio } \\
\text { da Clientela }\end{array}$ & $\begin{array}{l}\text { Corpo } \\
\text { Clínico }\end{array}$ & Localizą̧ào & $\begin{array}{c}\text { N.o de } \\
\text { Médicos }\end{array}$ & $\begin{array}{c}N^{\circ} \\
\text { Enfermeiros }\end{array}$ & $\begin{array}{c}N^{\circ} \\
\text { Auxiliares' } \\
\text { Técnicos }\end{array}$ \\
\hline A & $P(43)$ & $\mathrm{Pr}$ & G & $T$ & $S$ & $F$ & 0 & 6 & 1 & 11 \\
\hline B & $\mathrm{P}(42)$ & $P$ & G & $\mathbf{S}$ & $\mathrm{S}$ & $F$ & 0 & 6 & 1 & 19 \\
\hline $\mathrm{C}$ & $P(24)$ & $\mathrm{Pr}$ & G & 5 & $S$ & $\mathrm{~F}$ & 0 & 8 & 1 & 9 \\
\hline $\mathrm{D}^{\circ}$ & $M(147)$ & $F$ & G & $T$ & $\mathrm{C}$ & $F$ & 1 & 98 & 22 & 68 \\
\hline$E$ & $M(53)$ & $\mathbf{P}$ & G & $s$ & $\mathrm{~S}$ & $\mathbf{F}$ & 0 & 20 & 8 & 40 \\
\hline$F$ & $P(50)$ & $\overline{P T}$ & G & $\mathrm{PC}$ & C & A & 1 & 5 & 1 & 10 \\
\hline $\mathrm{G}^{*}$ & $M(61)$ & $F$ & $E$ & 5 & $S$ & $F$ & I & 33 & 1 & 30 \\
\hline $\mathrm{H}$ & $P(21)$ & $\bar{P}$ & G & $S$ & $S$ & $\mathbf{F}$ & o & 5 & 1 & 8 \\
\hline $\bar{I}$ & $P(50)$ & $F$ & G & $T$ & $S$ & $F$ & 0 & 7 & 1 & 9 \\
\hline J & $P(30)$ & $\bar{p}$ & G & $S$ & S & $F$ & 0 & 10 & 2 & 12 \\
\hline $\bar{K}$ & $P(44)$ & $\mathrm{Pr}$ & G & $T$ & $\mathrm{~S}$ & $F$ & 0 & 6 & 1 & 11 \\
\hline $\mathrm{L}^{*}$ & $G(153)$ & $\mathbf{P}$ & $\bar{G}$ & $\mathrm{~s}$ & $\mathrm{~s}$ & $\bar{F}$ & 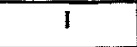 & 65 & 32 & 118 \\
\hline $\mathbf{M}$ & $P(30)$ & $\mathbf{P}$ & G & 5 & $S$ & $F$ & 0 & 6 & 1 & 10 \\
\hline $\mathrm{N}$ & $M(70)$ & $\mathrm{Pr}$ & $E$ & $T$ & $\bar{S}$ & $F$ & 1 & 8 & 2 & 30 \\
\hline 0 & $P(12)$ & $P$ & G & 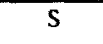 & $\bar{s}$ & $\bar{F}$ & $\overline{0}$ & 7 & 1 & 7 \\
\hline $\mathbf{P}$ & $M(61)$ & $F$ & G & $T$ & $\mathrm{~s}$ & $F$ & 0 & 7 & 1 & 3 \\
\hline$Q$ & $P(17)$ & $P$ & G & $S$ & $S$ & $F$ & 0 & 7 & 1 & 9 \\
\hline$R$ & $P(30)$ & $P$ & G & $\mathrm{s}$ & $\mathrm{S}$ & $\mathrm{F}$ & 0 & 6 & 1 & 10 \\
\hline$S$ & $P(36)$ & $\mathbf{P}$ & G & $\mathrm{s}$ & $S$ & $F$ & 0 & 8 & 1 & 13 \\
\hline$T *$ & $G(175)$ & $F$ & $E$ & $T$ & 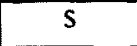 & $F$ & I & 66 & 16 & 215 \\
\hline $\mathrm{U}$ & $M(70)$ & $\mathrm{Pr}$ & G & 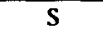 & $S$ & A & $I$ & 15 & 1 & 35 \\
\hline $\mathrm{v}$ & $P(24)$ & $P$ & G & $S$ & $S$ & $F$ & 0 & 7 & 1 & 9 \\
\hline$x$ & $M(110)$ & $\overline{\operatorname{Pr}}$ & G & $T$ & $\mathrm{C}$ & A & I & 26 & 1 & 38 \\
\hline$z$ & $M(110)$ & $\bar{F}$ & G & $\mathrm{S}$ & $S$ & $\bar{F}$ & 0 & 12 & 1 & 32 \\
\hline$w$ & $M(68)$ & $\mathrm{P}$ & G & $\bar{S}$ & $S$ & $F$ & o & 5 & 1 & 13 \\
\hline
\end{tabular}

\begin{tabular}{|c|c|c|c|c|c|c|}
\hline PORTE & $\begin{array}{c}\text { IINCULACAOO } \\
\text { ADMINISTRATII'A' } \\
\text { STATUS FINANCEIRO }\end{array}$ & $\begin{array}{l}\text { NATUREZA DO } \\
\text { ATENDIMENTO }\end{array}$ & $\begin{array}{l}\text { TIPODE } \\
\text { CLIENTELA } \\
\text { ATENDIDA }\end{array}$ & $\begin{array}{c}\text { PREDOMINIO } \\
\text { DA CLIENTELA }\end{array}$ & $\begin{array}{c}\text { CORPO } \\
\text { CLINICO }\end{array}$ & LOCALIZACÃO \\
\hline $\begin{array}{c}\mathbf{P} \\
\text { Pequeno }\end{array}$ & \begin{tabular}{|c|}
$\mathbf{p}$ \\
Público \\
\end{tabular} & $\begin{array}{c}\text { G } \\
\text { Geral }\end{array}$ & $\begin{array}{c}\mathrm{T} \\
\text { Todas (Particular, } \\
\text { Convênios, SUS) }\end{array}$ & $\begin{array}{c}\text { S } \\
\text { SUS }\end{array}$ & $\begin{array}{c}\text { A } \\
\text { Aberto }\end{array}$ & $\stackrel{\text { I }}{\text { Itabuna }}$ \\
\hline $\begin{array}{c}\mathbf{M} \\
\text { Médio }\end{array}$ & $\begin{array}{c}\mathbf{P r} \\
\text { Privado }\end{array}$ & \multirow{2}{*}{$\frac{\mathbf{E}}{\text { Especializado }}$} & $\begin{array}{c}\mathbf{P} \\
\text { Particular }\end{array}$ & \multirow{2}{*}{$\begin{array}{c}\text { C } \\
\text { Convênios }\end{array}$} & \multirow{2}{*}{$\underset{\text { Fechado }}{\mathbf{F}}$} & \multirow{2}{*}{$\begin{array}{c}\mathbf{0} \\
\text { Outras Cidades }\end{array}$} \\
\hline $\begin{array}{c}\mathbf{G} \\
\text { Grande }\end{array}$ & $\begin{array}{c}\mathbf{F} \\
\text { Filantrópico }\end{array}$ & & $\begin{array}{c}\text { C } \\
\text { Convènios }\end{array}$ & & & \\
\hline
\end{tabular}

\subsubsection{Instrumento para coleta de dados}

Para a análise das estruturas hospitalares relacionadas à biossegurança, foi utilizado formulário adaptado de OLIVEIRA (1997) e BAHIA (2001), aplicado aos enfermeiros dos grupos executores do controle de infecção hospitalar ou ao presidente das 
comissões de controle, ou aos enfermeiros das $\mathrm{CCIHs}$ e, na indisponibilidade desses, à coordenação de enfermagem.

Esse formulário (Anexo 1) constou de questões referentes aos dados do hospital, caracterização da $\mathrm{CClH}$; à caracterização da Comissão Institucional de Prevenção a Acidentes (CIPA), à existência de normas escritas para precauções padrão; à existência de normas escritas para precauções baseadas na transmissão; à realização de treinamentos para essas mesmas preconizações; à existência de registros institucionais concernentes à biossegurança, quais sejam, o registro de ocorrência de acidentes com materiais pérfuro-cortantes; o registro de cobertura vacinal dos profissionais para a hepatite B e a existência de mapas de riscos. Também fazem parte do instrumento questões referentes à existência de práticas de atenção à saúde dos profissionais, incluindo-se exames médicos admissionais; programa de imunização dos trabalhadores e realização de PPD periódico e, por fim, isolamento de paciente com tuberculose e a existência de unidades de isolamento de pacientes com doenças transmissíveis. O próximo quadro sumariza o conjunto de itens utilizados no estudo descritivo das estruturas hospitalares. 
Quadro 1 - Conjunto de itens considerados para análise da estrutura hospitalar relativa à biossegurança.

1 - Infra-Estrutura Organizacional
a - Existência de CCIH.
b - Pelo menos um membro da CCIH treinado em biossegurança.
c - Existência de CIPA.
d - Pelo menos um membro da CIPA treinado em biossegurança.

2 - Presença de normas escritas para:

a - Precauções padrão.

b - Precauções baseadas na transmissão.

c - Condutas frente a acidentes com materiais pérfuro-cortantes.

3 - Realização de treinamento de pessoal para:

a - Precauções padrão.

b - Precauções baseadas na transmissão.

c - Triagem precoce de pacientes suspeitos de tuberculose.

4 - Realização de registros

a - Presença de mapas de risco.

b - Presença de registros de acidentes com materiais pérfuro-cortantes.

c - Registro de cobertura vacinal para hepatite B.

5 - Atenção médica admissional e rotinas de imunização profissional.

a - Exigência de exame médico admissional.

b - Existência de rotina de imunização de profissionais para hepatite B.

c - Realização de PPD periódico de profissionais atuantes diretamente com pacientes em área de risco para a tuberculose.

6 - Isolamento de pacientes

a - Prática de se isolar paciente suspeito de tuberculose.

b - Existência de adequadas acomodações para isolamento.

\subsubsection{Tratamento estatístico dos dados}

Para o tratamento dos dados, procedemos além de análise da proporção dos itens considerados para fins do estudo, presentes nos hospitais, à análise das distinções e similaridades entre hospitais. Essa, de acordo com as subdivisões segundo porte, vinculação administrativo-financeira, ou seja, se públicos, privados e filantrópicos, natureza geral ou especializada, e, ainda, segundo o predomínio da clientela atendida sob o ponto de vista da remuneração pelos serviços, do corpo clínico do hospital (se 
aberto e fechado), de sua caracterização enquanto se prestar ou não a campo formal de ensino de profissionais da área de saúde e, por fim, do ponto de vista da sua localização geográfica, se na cidade considerada como polo regional, Itabuna, ou fora dela. Complementarmente também analisamos os hospitais segundo subdivisão com ou sem $\mathrm{CCIH}$ e grupo executor de controle de infecção hospitalar, em respeito à presença de normas e rotinas( itens 2 à 6 e respectivos subitens do quadro 1)

Para a análise dos efeitos das características hospitalares sobre a ocorrência de itens concernentes à biossegurança, os hospitais, uma vez agrupados, foram, a princípio, analisados em relação a cada questão em particular.

Para tal, utilizamos o teste quiquadrado ou exato de Fisher, conforme a presença de valor esperado inferior à cinco para pelo menos uma das situações: resposta afirmativa ou negativa (analisadas, respectivamente, como 1 e 0 ) de um grupo qualquer, o que definia a aplicação do segundo (SAS INSTITUTE 1988). Ao invés de fixar o nível de significância para a rejeição da hipótese estatística, optou-se por colocar no texto o nível de significância da amostra ( $\mathrm{p}$ valor). Consideramos, para fins de admitir que as diferenças não tenham ocorrido ao acaso o limite de $15 \%$ de probabilidade.

Analisamos também as diferenças entre os grupos de hospitais, para o conjunto de questões (listadas no Quadro 1). Nesses casos, obtivemos para cada hospital, a média referente ao total de respostas afirmativas e negativas para cada grupo de questões especificas e, a partir dessas aplicamos o método de análise não paramétrico de escores medianos, no qual é assumido o valor 1 ou 0 , conforme a média de cada hospital seja maior ou menor que o valor da mediana do conjunto de médias de todos os hospitais (SAS INSTITUTE 1988).

Por fim, para uma visualização geral das diferenças entre hospitais para o conjunto geral de itens, estimamos a matriz de distâncias entre hospitais, considerando a coincidência simples (distância $=1$ - somatório de todos os eventos sim-sim e não- não / todos os eventos sim-sim, sim-não, não-sim e não-não) (Cruz, 1997) e a partir dessa, através do método'Multidemensional Scaling' (YOUNG, 1985) - MDS plot e SAS GRAPH (SAS INSTITUTE 1988), confeccionamos figuras tridimensionais das referidas distâncias. 


\subsubsection{Análise do processo}

Para a descrição de aspectos da forma com que as normas de auto-proteção relacionadas à venipunção são colocadas em prática pelos profissionais, os dados foram coletados em três das instituições constantes da pesquisa concernente aos dados estruturais.

Circunscreveu-se a coleta de dados de observação à parte das instituições face à impossibilidade, por problemas cronológicos e operacionais, de se proceder observação processual em todas os hospitais estudados nos aspectos atinentes à estrutura dos serviços. A escolha dos hospitais se deu em função do maior número de atendimentos de pacientes e, conseqüentemente, estimativa de maiores possibilidades de observação das técnicas eleitas.

A eleição da observação de procedimentos de venipunção se fez, por outro lado, em função de constituírem-se em atividades relativamente rotineiras, de certa facilidade de observação, além de representarem procedimentos de risco para agentes biológicos, com destaque para o HVB, HCV e o próprio HIV.

Foram despendidas para essa fase de coleta de dados duzentas e quarenta horas de observação, distribuídas entre os três hospitais.

Trabalhou-se então com o hospital D, que conforme pode ser visualizado na tabela 1 , constitui-se em instituição de médio porte, filantrópica, destinada ao atendimento geral. O hospital L, também geral, mas público e de grande porte e, por fim, o hospital T, de grande porte, filantrópico e especializado em pediatria e obstetrícia. Em respeito aos setores hospitalares dentro de cada hospital, procedeu-se à observação, nos dois hospitais gerais, em uma unidade de internação de cada um, escolhidas aleatoriamente e nos seus respectivos prontos socorros. No hospital especializado em pediatria e obstetrícia as observações foram procedidas em uma unidade de internamento pediátrico, no pronto socorro pediátrico, berçário e unidade de atendimento intermediário infantil (UTE). 


\subsubsection{Instrumento para coleta de dados}

Utilizamos para a coleta de dados referente ao processo, roteiro de observação (Instrumento de Coleta de dados II - Anexo 2), no qual foram considerados, na descrição dos diferentes procedimentos de acesso venoso, cinco passos, a saber: lavagem das mãos antes do procedimento (ainda que não considerada propriamente uma medida de auto-proteção, mas pedra angular da prevenção de infecções dos pacientes em hospitais); uso de luvas para a execução da técnica em questão; descarte da agulha de imediato; não re-encape das agulhas e lavagem das mãos após a realização dos procedimentos. Tais passos fazem parte das normas atinentes às precauções padrão.(APCIH,1999).

\subsubsection{Tratamento estatístico dos dados}

Para a análise dos dados concernentes à incorporação das medidas de auto-proteção na realização dos procedimentos de venipunção, utilizou-se dos testes de quiquadrado ou exato de Fisher, conforme a presença de valor esperado inferior à cinco para pelo menos uma das situações: resposta afirmativa ou negativa (analisadas, respectivamente, como 1 e 0) de um grupo qualquer, o que definia a aplicação do segundo (SAS INSTITUTE 1988).

De igual modo ao procedido na análise dos dados referentes às estruturas dos serviços optamos por registrar no texto o $\mathrm{p}$ valor e consideramos para admitir que as diferenças não tenham ocorrido ao acaso, o limite de $15 \%$ de probabilidade.

Para o estudo da adesão às medidas, levando em conta o tempo de formado dos profissionais, utilizou-se da média dos profissionais para cada item, que foram analisadas por método de análise não paramétrica de escores medianos (SAS INSTITUTE 1988), que define valores de 1 para aqueles superiores à mediana e 0 (zero) para os inferiores . 


\subsubsection{Estudo das percepções dos profissionais acerca de temas relativos à biossegurança.}

\subsubsection{Estratégia metodológica}

Para o estudo das percepções dos sujeitos da pesquisa sobre os temas relativos à biossegurança lançamos mão de proposta de LEFĖVRE et al (2000), denominada de Discurso do Sujeito Coletivo (DSC).

Tal técnica é de cunho qualitativo. Seu emprego permitiu-nos produzir dados descritivos no seu mais amplo sentido e, além disso, compreender os fenômenos relativos às práticas de auto-proteção, através dos discursos dos profissionais da saúde atuantes em hospitais.

Permitiu-nos ainda o entendimento de um universo de significados, motivos, aspirações, crenças, valores, atitudes, enfim, de sentidos, conforme bem enfatizam MINAYO (1996) e SPINK e MEDRADO (2000), no que tange à biosssegurança.

A técnica proposta por LEFÈVRE et al tem, como base, o pressuposto de que as abordagens qualitativas são capazes, com maior propriedade, de incorporar a questão do significado e da intencionalidade como inerentes aos atos, às relações e às estruturas sociais, sendo essas últimas tomadas tanto no seu advento quanto na sua transformação, como construções humanas significativas.

Também para os autores, o significado e a intencionalidade, que ocupam posições centrais na pesquisa social, aparecem muito mais claras e naturalmente nos discursos. Assim, pelo espaço proeminente desses últimos, a abordagem qualitativa permite uma compreensão mais aprofundada dos campos sociais e dos sentidos neles presentes.

De acordo com os mesmos autores o Discurso do Sujeito Coletivo é uma estratégia metodológica que busca tornar mais clara uma dada representação social. Por meio do recurso em foco, visualizamos melhor a representação, na medida que ela aparece na forma mais viva e direta de um discurso, ou seja, do modo como indivíduos reais se expressam. 


\subsubsection{Organização dos dados}

Para a construção dos discursos dos sujeitos coletivos, figura metodológica fulcral e que dá nome à técnica, partimos, conforme proposto por LEFÉVRE et al (2000), de exaustiva leitura das falas individuais resultantes da interpelação de cada questão norteadora proposta (instrumento de coleta de dados III- anexo 3); associamos em seguida os conteúdos significativos (expressões chaves) presentes em cada construção discursiva de cada sujeito às suas respectivas idéias centrais. Essas últimas, compreendidas como figura metodológica, que permite traduzir o essencial das falas explicitadas pelos sujeitos em seus depoimentos, foram sintetizadas de sorte a expressar todas as idéias centrais de mesmo sentido. Por último, sob a égide destas idéias centrais-síntese, procedeu-se a agregação das expressões chaves respectivas, de modo a formar um todo discursivo coerente.

Assim, para cada questão, foram construidos tantos DSCs, quantas idéias centraissintese fossem captadas.

\subsubsection{População e amostra (Os sujeitos do estudo)}

Como população da pesquisa, consideramos os médicos, enfermeiros e auxiliares e técnicos de enfermagem, todos envolvidos na prática assistencial e atuantes nos hospitais campos do estudo.

A delimitação das citadas categorias a virem a ser analisadas em seus discursos, deu-se em função de abarcarem os profissionais que, de acordo com a literatura, se expõem mais freqüentemente aos riscos biológicos em hospitais, considerando-se as práticas assistenciais e na plausibilidade de construção e, subsequente aplicação, de um único instrumento de coleta de dados.

Esta explicação se faz necessária, pois também outros profissionais e ocupacionais, de igual modo expõem-se a riscos biológicos. As especificidades, contudo, das suas atuações e até mesmo a circunscrição destas últimas a campos aqui possivelmente não 
aprofundados, demandaria diferentes instrumentos e conseqüente desalinhamento no foco da pesquisa.

Delimitadas as categorias profissionais, os seus representantes foram convidados a participar do estudo por esta pesquisadora, nos seus postos de trabalho.

Os critérios de inclusão foram o de exercerem atividades assistenciais junto a pacientes e estarem presentes nas unidades respectivas nas várias visitas empreendidas pela pesquisadora aos diferentes setores de atendimento do hospital.

Buscamos, outrossim, uma proporcionalidade numérica de entrevistados por categoria profissional atuante nos diferentes hospitais(uma aproximação de pelo menos $10 \%$ de cada categoria em cada instituição estudada), conquanto não se constitua em preocupação fundamental das pesquisas qualitativas os aspectos numéricos de amostragem, mas principalmente a questão da intencionalidade na questão da escolha da amostra.

Cumpre-nos ainda referir que, no caso específico dos profissionais enfermeiros, não foram todos os hospitais eleitos como lócus do estudo, descritos adiante, que tiveram representação no estudo qualitativo, posta a existência de um único profissional nessas mesmas instituições e, conseqüentemente com limitada atuação assistencial. Ademais esses profissionais constituíram-se naqueles que foram entrevistados nos aspectos relativos à estrutura dos serviços.

Conforme melhor explicado no próximo item, os lócus do estudo foram os hospitais situados na cidade de Itabuna. O total de profissionais das diferentes categorias atuantes nesses mesmos hospitais, podem ser visualizados na tabela $1, \mathrm{p} 25$, sob a abreviação I (de Itabuna), no que se refere à localização geográfica .

No quadro abaixo relacionamos as características dos profissionais entrevistados e seus respectivos hospitais de atuação. Os totais de profissionais entrevistados foram de vinte médicos, treze enfermeiros e quarenta e um auxiliares/técnicos de enfermagem. 
Quadro 2 - Profissionais entrevistados e respectivas especialidades/unidades de atuação

Médicos

\begin{tabular}{|c|c|c|c|c|}
\hline Entrevistados & Hospital * & Especialidade & Sexo & $\begin{array}{l}\mathrm{N} .{ }^{\circ} \text { de anos de } \\
\text { formado }\end{array}$ \\
\hline E 1 & $\mathrm{~F}$ & Ortopedia & $\mathrm{M}$ & 20 \\
\hline E 2 & $\mathrm{~T}$ & Ginecologia/Obstetricia & $M$ & 28 \\
\hline E 3 & $\mathrm{~T}$ & Pediatria & $\mathrm{F}$ & 17 \\
\hline $\mathrm{E} 4$ & $T$ & Anestesiologia & $M$ & 25 \\
\hline E5 & $\mathrm{D}$ & Cirurgia Geral & $M$ & 23 \\
\hline E6 & D & Clinica (Pneumologia) & $M$ & 18 \\
\hline E 7 & $\mathrm{D}$ & Cirurgia (Urologia) & $M$ & 24 \\
\hline E 8 & $\mathrm{D}$ & Clínica (Pneumologia) & $\mathrm{M}$ & 27 \\
\hline E 9 & $\mathrm{D}$ & Clínica (Terapia Intensiva) & $\mathrm{F}$ & 16 \\
\hline E 10 & $\mathrm{D}$ & Cirurgia (Vascular) & $M$ & 11 \\
\hline E 11 & $L$ & Ortopedia & $\mathrm{M}$ & 6 \\
\hline E 12 & $L$ & Cirurgia (Urologia) & $M$ & 5 \\
\hline E 13 & $\mathrm{~L}$ & Anestesiologia & $\mathrm{M}$ & 23 \\
\hline E 14 & $\mathrm{~L}$ & Clínica (Terapia Intensiva) & $M$ & 9 \\
\hline E 15 & $L$ & Ortopedia & $\mathrm{M}$ & 37 \\
\hline E 16 & $\mathrm{U}$ & Clinica & $\mathrm{M}$ & 18 \\
\hline E 17 & $\mathrm{X}$ & Cirurgia Geral & $\mathrm{M}$ & 37 \\
\hline E 18 & $\mathrm{X}$ & Clinica & $\mathrm{M}$ & 39 \\
\hline E 19 & $\mathrm{~N}$ & Pediatria & $\mathrm{M}$ & 26 \\
\hline E20 & $\mathrm{G}$ & Ginecologia/Obstetricia & $\mathrm{M}$ & 10 \\
\hline
\end{tabular}

* Identificaçào do hospital por letra. de acordo com a tabela !

\section{Enfermeiros}

\begin{tabular}{|c|c|c|c|c|}
\hline Entrevistados & Hospital & Setor de atuação & Sexo & $\begin{array}{c}\text { N. }{ }^{\circ} \text { de anos de } \\
\text { formado }\end{array}$ \\
\hline E 1 & T & $\begin{array}{c}\text { Unidade de Internamento } \\
\text { Pediátrico/Maternidade }\end{array}$ & $\mathrm{F}$ & 18 \\
\hline E 2 & $\mathrm{T}$ & Unidade de Internamento Pediátrico & $\mathrm{F}$ & 3 \\
\hline E 3 & $\mathrm{T}$ & $\begin{array}{c}\text { Unidade de Internamento } \\
\text { Pediátrico/Maternidade }\end{array}$ & $\mathrm{F}$ & 10 \\
\hline E 4 & $\mathrm{T}$ & Centro Obstétrico/Maternidade & $\mathrm{F}$ & 5 \\
\hline E 5 & $\mathrm{T}$ & $\begin{array}{c}\text { Maternidade/Berçário- } \\
\text { Unidade de Internamento pediátrico }\end{array}$ & $\mathrm{F}$ & 2 \\
\hline E 6 & $\mathrm{T}$ & $\begin{array}{c}\text { Unidade de Internamento Pediátrico } \\
\text { (Oncologia) }\end{array}$ & $\mathrm{F}$ & 4 \\
\hline E 7 & $\mathrm{D}$ & Hemodiálise & $\mathrm{F}$ & 10 \\
\hline E 8 & $\mathrm{D}$ & Pronto Socorro & $\mathrm{F}$ & 2 \\
\hline E 9 & $\mathrm{D}$ & Unidade de Internamento & $\mathrm{F}$ & 4 \\
\hline E 10 & $\mathrm{D}$ & Unidade de Terapia Intensiva & $\mathrm{F}$ & 10 \\
\hline E 11 & $\mathrm{L}$ & Pronto Socorro & $\mathrm{F}$ & 1 \\
\hline E 12 & $\mathrm{L}$ & Unidade de Terapia Intensiva & $\mathrm{F}$ & 5 \\
\hline E 13 & $\mathrm{L}$ & Unidade de Internamento & $\mathrm{F}$ & 2 meses \\
\hline
\end{tabular}


Auxiliares e Técnicos de Enfermagem

\begin{tabular}{|c|c|c|c|c|}
\hline Entrevistados & Hospital & Setor de atuação & Sexo & $\begin{array}{l}\text { N. }{ }^{\circ} \text { de anos de } \\
\text { formado }\end{array}$ \\
\hline EI & $\mathrm{T}$ & Berçário & $\mathrm{F}$ & 10 meses \\
\hline E 2 & $\mathrm{~T}$ & Unidade de Internamento Pediátrico & $\mathrm{F}$ & 9anos \\
\hline E3 & $\mathrm{T}$ & Berçário & $\mathrm{F}$ & 22 anos \\
\hline E4 & $T$ & Maternidade & $\mathrm{F}$ & 18 anos \\
\hline E5 & $T$ & Maternidade & $\mathrm{F}$ & 6anos \\
\hline E 6 & $T$ & Maternidade & $\mathrm{F}$ & 14 anos \\
\hline E 7 & $\mathrm{~T}$ & Maternidade & $\mathrm{F}$ & 9 anos \\
\hline E 8 & $\mathrm{~T}$ & Unidade de Internamento Pediátrico & $\mathrm{F}$ & 10 meses \\
\hline E9 & $\mathrm{D}$ & Unidade de Internamento & $\mathrm{M}$ & 10 anos \\
\hline E 10 & D & Pronto Socorro & $\mathrm{M}$ & 4 anos \\
\hline E 11 & D & Unidade de Terapia Intermediária & $\mathrm{F}$ & 6 anos \\
\hline E 12 & D & Pronto Socorro & $\mathrm{F}$ & 3 anos \\
\hline E 13 & $\mathrm{D}$ & Pronto Socorro & $\mathrm{F}$ & 12 anos \\
\hline E 14 & D & Unidade de Internamento & $\mathrm{M}$ & 9 anos \\
\hline E 15 & D & Unidade de Hemodiálise & $\mathrm{F}$ & 3 anos \\
\hline E 16 & $\mathrm{D}$ & Unidade de Terapia Intensiva & $\mathrm{M}$ & 6 anos \\
\hline E 17 & D & Unidade de Terapia Intensiva & $\mathrm{F}$ & 8 anos \\
\hline E 18 & D & Pronto Socorro & $\mathrm{F}$ & 19 anos \\
\hline E 19 & D & Unidade Intermediária & $\mathrm{F}$ & 25 anos \\
\hline E 20 & $\mathrm{~F}$ & Unidade de Internamento & $\mathrm{F}$ & 22 anos \\
\hline E21 & $\mathrm{F}$ & Unidade de Internamento; Centro Cirúrgico & $\mathrm{F}$ & 13 anos \\
\hline E 22 & $\mathrm{U}$ & Unidade de Internamento & $\mathrm{F}$ & 12 anos \\
\hline E 23 & $\mathrm{U}$ & Unidade de Internamento & M & 1 ano \\
\hline E 24 & $U$ & Unidade de Internamento & $\mathrm{F}$ & 7 anos \\
\hline E 25 & $\mathrm{X}$ & Unidade de Internamento; Centro Cirúrgico & $\mathrm{F}$ & 18 anos \\
\hline E 26 & $\mathrm{X}$ & Berçário & $\mathrm{F}$ & 3 anos \\
\hline E 27 & $\mathrm{x}$ & Berçário & $\mathrm{F}$ & 18 anos \\
\hline E 28 & $\mathrm{X}$ & Pronto Socorro - Centro Cirúrgico & $\mathrm{M}$ & 5 anos \\
\hline E 29 & $\mathrm{~N}$ & Unidade de Internamento Pediátrico & $\mathrm{F}$ & 9 anos \\
\hline E 30 & $\mathrm{~N}$ & Unidade de Internamento Pediátrico & $\mathrm{F}$ & 20 anos \\
\hline E 31 & $\mathrm{~N}$ & Unidade de Internamento Pediátrico & $\mathrm{F}$ & 25 anos \\
\hline E 32 & $\mathrm{~N}$ & Unidade de Internamento Pediátrico & $\mathrm{F}$ & 12 anos \\
\hline E 33 & $\mathrm{G}$ & Maternidade/Centro Obstétrico & $\mathrm{F}$ & 15 anos \\
\hline E 34 & $\mathrm{G}$ & Berçário & $\mathrm{F}$ & 15 anos \\
\hline E 35 & $\mathrm{G}$ & Berçário & $\mathrm{F}$ & 15 anos \\
\hline E 36 & G & Berçário & $\mathrm{F}$ & 19 anos \\
\hline E 37 & $\mathrm{~L}$ & Pronto Socorro & $\mathrm{F}$ & 7 anos \\
\hline E 38 & $\mathrm{~L}$ & Pronto Socorro & $\mathrm{F}$ & 8 anos \\
\hline E 39 & $\mathrm{~L}$ & Unidade de Internamento & $\mathrm{F}$ & 15 anos \\
\hline E 40 & $\mathrm{~L}$ & Agência Transfusional & $\mathrm{F}$ & 3 anos \\
\hline E 41 & $\mathrm{L}$ & Unidade de Internamento & $\mathrm{F}$ & 3 anos \\
\hline
\end{tabular}




\subsubsection{Locus do estudo}

Delimitamos, como locais do estudo, os hospitais da cidade de Itabuna. Essa delimitação, ao contrário do trabalho descritivo, que compreendeu a análise de maior número de instituições e de cidades, se deu em função da própria natureza do estudo qualitativo, que demanda uma visão mais intensiva e de profundidade do que propriamente um empreendimento mais extensivo.

Por outro lado, compreendemos que, ao se estudar os discursos de profissionais atuantes em todos os hospitais de uma dada cidade, que, de alguma forma, tem suas semelhanças às demais, no que se refere à atuação dos profissionais no seu conjunto, vislumbramos uma boa medida de como o tema biossegurança perpassa diferentes categorias profissionais, até se levando em conta diferentes localizações. Não obstante, ressaltemos que não se pretende e nem constitui-se missão do estudo qualitativo conferir caráter de universalização dos seus resultados.

\subsubsection{Instrumento para coleta de dados}

Para a coleta de dados, utilizamos roteiro de entrevista, que constou, além de dados complementares como profissão e campo de atuação, seis questões norteadoras, através das quais buscamos captar os conteúdos discursivos dos profissionais afetos ao tema maior desse estudo, a biossegurança (Anexo3).

Conforme já citado, as entrevistas foram empreendidas nos próprios locais de trabalho e levadas à efeito em ambientes destinados a reuniões, descanso ou mesmo guarda de materiais e equipamentos, à escolha dos próprios entrevistados.

Os conteúdos foram gravados, com a respectiva anuência dos sujeitos da pesquisa, para subseqüente transcrição, tratamento e análise.

A escolha da entrevista como técnica de coleta de dados se fez em consonância com o próprio objeto de estudo, a percepção dos sujeitos acerca de temas relacionados ao foco 
maior do estudo, a biossegurança e da própria estratégia metodológica de tratamento dos dados aqui eleita, a construção dos discursos dos sujeitos coletivos.

\subsection{Estudo Piloto}

Com o intento de validar e aprimorar os instrumentos de coleta de dados, levamos, a efeito, estudo piloto.

No caso do instrumento de coleta de dados da estrutura hospitalar (Anexo 1), esse foi aplicado a dois enfermeiros atuantes em $\mathrm{CCIHs}$ de hospitais não incluídos no estudo e, face a deteç̧ão de alguns defeitos de conteúdo e de forma de abordagem, procedemos ajustes pertinentes.

Submetemos ainda o mesmo formulário à validação de três especialistas, um em epidemiologia e dois em $\mathrm{CCIH}$. Desses dois últimos, um deles responsável pela administração de reconhecido site especializado em controle de infecções hospitalares.

Por sua vez o instrumento destinado ao estudo observacional e o roteiro de entrevistas referente ao trabalho qualitativo, foram testados através da aplicação em três oportunidades cada um, nos próprios hospitais campo de estudo.Em ambos os instrumentos foram procedidos ajustes antes da utilização definitiva.

\subsection{Aspectos Éticos}

Antecedeu à fase de coleta de dados, a anuência das respectivas direções das instituições campos da pesquisa, após apresentação de ofício solicitando autorização para realização do trabalho, o qual explicita os objetivos da investigação, os métodos e procedimentos do trabalho, sua importância e contribuição ao estudo da biossegurança.

Além da autorização das instituições pelos órgãos competentes, a realização das entrevistas e observação das atividades, somente foi procedida após o devido consentimento livre e esclarecido de cada um dos sujeitos (Anexo 4). 
Ressaltamos, entretanto, que no caso do estudo de observação, com vistas a evitar possível interferência do conhecimento dos aspectos nos quais os sujeitos seriam observados, isto é, suas respectivas ações cotidianas afetas à biossegurança e com vistas também a preservar os aspectos éticos inerentes às pesquisas que envolvem seres humanos, os profissionais presentes nos locais e momentos da coleta de dados eram convidados a participar do trabalho e procediam, no caso de anuência, à assinatura dos respectivos termos de consentimento e faziam-se cientes de que em algum momento seriam observados sem, contudo, conhecer em que intervalo e em que atividades, ou então, depois de procedida à observação o profissional era convidado a participar da pesquisa e, somente após seu consentimento, os dados eram registrados.

Dados complementares necessários à caracterização dos profissionais, cujas atividades foram observadas, foram coletados buscando-se não despertar sobre meios de se relacionar em que estariam sendo observados.

Cumpre-nos registrar, por fim, que em atendimento às regulamentações da Faculdade de Saúde Pública da USP , o projeto de pesquisa foi devidamente aprovado pelo Comitê de Ética e Pesquisa do respectivo órgão de ensino.

\subsection{Limitações do estudo}

Cabe-nos, antes de passarmos aos resultados encontrados, reconhecer as limitações do estudo. Inicialmente no concernente à proposta de descrever as características dos hospitais relativas à sua estrutura de biossegurança na prática assistencial. A primeira delas refere-se a dificuldade de se estabelecer um "cut point" de itens passíveis de serem empregados em instituições que tem sempre suas peculiaridades. A segunda refere-se ao modesto poder analítico resultante de uma baixa qualidade amostral de instituições estudadas, não obstante o fato de se buscar trabalhar com todo o universo de hospitais de uma dada região.

No atinente ao estudo do processo de trabalho, a maior limitação diz respeito à escolha de uma técnica que permita comparar as práticas de diferentes categorias profissionais. 
Assim, ainda que elegendo a técnica de punções vasculares que, em tese, é executada pelas três categorias profissionais aqui consideradas como sujeitos do estudo, deparamo-nos com um número modesto de procedimentos nos setores hospitalares nos quais procedemos ao estudo de observação, realizados por médicos e também por enfermeiros. Tal limitação determina dificuldades de comparações mais consubstanciadas.

Ademais, cumpre-nos referir que não nos ativemos na observação de um único procedimento para cada um dos profissionais. Isso permitiu que um mesmo profissional pudesse ser observado mais vezes, o que pode corroborar para que sua prática, acertada ou não, possa ter sido mais representada.

Outra limitação diz respeito à restrição do tempo de observação, o que reduziu em muito o número de procedimentos observados nos casos de alguns setores hospitalares nos quais tais procedimentos ocorrem com uma dinâmica mais específica. Em alguns casos, as observações foram inviáveis, como nas unidades de terapia intensiva de adultos, posto que não ocorreram os procedimentos em foco durante os períodos estipulados para a coleta de dados.

Ainda assim, apesar de todas essas limitações, a análise dos aspectos do modus operandi das técnicas aqui em tela, haja vista a expressividade do número de procedimentos observados como um todo (339), nos proporciona um retrato aproximado da realidade. Até mesmo o número de profissionais observados (90 no total) pode ser considerado como razoavelmente representativo.

Por fim, vale ressaltar que trata-se a pesquisa de estudo descritivo das realidades hospitalares e, desta forma, os resultados, tanto no que se refere à análise da estrutura como do processo de trabalho, nos servem para apontar tendências e não para estabelecer verdades.

Referente ao estudo qualitativo, devemos citar que de acordo com GIL (1999), a entrevista apresenta algumas limitações, dentre as quais pode-se citar a eventual falta de motivação do entrevistado em responder às indagações, a inadequada compreensão 
do significado das perguntas, bem como a plausível influência exercida pelo aspecto pessoal do entrevistador sobre o interlocutor.

Podemos, todavia, dizer que, no escopo específico deste estudo, buscamos contornar as limitações da técnica, na medida que a participação dos entrevistados, como não poderia deixar de ser, foi voluntária e precedida de breve explicação do assunto que seria tratado. Além disso, as questões foram previamente testadas com as diferentes categorias profissionais e, portanto, ajustadas para a devida clareza (Estudo piloto). 


\section{RESULTADOS - ESTRUTURA DE BIOSSEGURANÇA DOS HOSPITAIS}

\subsection{Infra-Estrutura Organizacional}

\subsubsection{Caracterização das CCIHs e das CIPAs}

De acordo com o explicitado no capitulo referente à metodologia deste presente estudo, consideramos como itens de uma infra-estrutura organizacional de biossegurança nos hospitais, a presença de $\mathrm{CCIH}$ e de CIPA e o respectivo treinamento de pelo menos um membro de cada um desses órgãos no tema afeto.

Assim, dos vinte e cinco hospitais estudados, dezenove (76\%) possuem $\mathrm{CClH}$ e seis (24\%) não dispõem do órgão. Todos os hospitais privados $(n=7)$ têm formalmente constituída $\mathrm{CCIH}$, ao passo que nos hospitais públicos e filantrópicos, elas estão presentes em $66,7 \%$ das instituições. Há também variação na existência de CCIH nos hospitais quando distribuidos por tamanho: os dois únicos hospitais de grande porte (100\%) têm $\mathrm{CCIH}$, seguidos pelos de tamanho médio $(80 \%)$ e daqueles de pequeno porte $(72,4)$. O tempo de funcionamento dessas mesmas $\mathrm{CCIHs}$ varia de alguns meses até dezesseis anos (Tabela 2).

Tabela 2 - Distribuição das CCIH dos hospitais sob estudo de acordo com o tempo decorrido de sua implantação. Itabuna-BA, 2001.

\begin{tabular}{lrr}
\hline Tempo decorrido da implantação (anos) & N." & \% \\
\hline$---\mid 01$ & 4 & 21,0 \\
$01---\mid 04$ & 2 & 10,5 \\
$04---\mid 08$ & 11 & 57,9 \\
$08--\mid 12$ & 1 & 5,3 \\
$12---\mid 16$ & 1 & 5,3 \\
\hline TOTAL & 19 & 100,0 \\
\hline
\end{tabular}


Das dezenove $\mathrm{CCIHs}$, apenas duas $(10,5 \%)$ possuem estatuto e a periodicidade das suas reuniões é bastante diversificada, variando de períodos superiores à seis meses (6 CCIHs - 31,6\%), reuniões mensais em igual número $(6-31,6 \%)$, encontros trimestrais (4-21,0\%) e semestrais (3-15,8\%).

Integram a composição das CCIHs, as figuras do médico e da enfermeira, sendo as demais categorias profissionais menos representadas (Tabela 3 ). O número de componentes dos respectivos órgãos é, por outro lado, variável de duas a cinco pessoas. A maioria das CCIHs, dez $(52,6 \%)$, é constituída por três componentes.

Tabela 3 - Profissionais presentes nas composições das CCIHs dos hospitais estudados. Itabuna-BA, 2001.

\begin{tabular}{lcc}
\hline \multicolumn{1}{c}{ Categoria Profissional } & $\mathbf{N .}^{\mathbf{0}^{*}}$ & $\mathbf{\%}^{*}$ \\
\hline Médico & 19 & 100,0 \\
Enfermeiro & 19 & 100,0 \\
Bioquímico/Farmacêutico & 6 & 31,6 \\
Auxiliar de Enfermagem & 4 & 21,0 \\
Administrador & 3 & 15,8 \\
Técnico de Laboratório & 2 & 10,5 \\
\hline
\end{tabular}

* Percentagem calculada sobre os dezenove hospitais que dispõem de $\mathrm{CCIH}$

Apenas três $(15,8 \%)$, das dezenove CCIHs, têm papéis delimitados entre os seus participantes, nas demais, o enfermeiro assume todas as funções inerentes ao trabalho. Em duas instituições nas quais há uma delimitação de papéis, o médico tem suas atividades circunscritas à padronização e acompanhamento do uso de antibióticos e em um dos hospitais, além dessa atribuição, afigura-se o auxílio à enfermeira na busca ativa dos casos de IH.

Os farmacêuticos/bioquímicos e técnicos de laboratórios são os responsáveis pela realização de exames microbiológicos solicitados. Os auxiliares de enfermagem dão apoio à enfermeira no acompanhamento de feridas infectadas e, em uma instituição, ocupam-se também da realização de notificações compulsórias e preenchimento de 
boletins mensais. Os profissionais da administração, presentes em três das instituições, conforme já citado, não possuem função específica.

As atividades dos enfermeiros nas comissões de controle de infecções hospitalares, as quais demonstram uma concentração nas ações da vigilância epidemiológica das Ihs, bem como na elaboração de planilhas destinadas à prestação de informações aos órgãos de direito, a despeito de demais ações como a educação continuada e implementação de isolamentos dentre outras, são as elencadas na tabela 4.

Tabela 4 - Atividades desenvolvidas pelos enfermeiros das CCIHs existentes nos hospitais sob estudo. Itabuna-BA, 2001.

\begin{tabular}{lcc}
\hline \multicolumn{1}{c}{ Atividades } & N. $^{\mathbf{o}^{*}}$ & $\mathbf{\%}^{*}$ \\
\hline Vigilância epidemiológica (método ativo) & 9 & 47,4 \\
Vigilância epidemiológica (método passivo) & 10 & 52,6 \\
Elaboração de planilhas e notificações & 19 & 100,0 \\
Educação Continuada dos Profissionais do Hospital & 3 & 15,8 \\
Implementação de Isolamentos & 1 & 5,3 \\
\hline
\end{tabular}

* Percentagem calculada sobre as dezenove CCIHs

A experiência em anos em $\mathrm{CCIH}$ desses mesmos enfermeiros, membros, conforme visto, mais atuantes nos respectivos órgãos é variável de alguns meses à dez anos. Verificamos que ocorre uma concentração nos hospitais públicos, de profissionais com até um ano de experiência $(87,5 \%)$, realidade diversa dos hospitais privados e dos hospitais filantrópicos, cuja maioria dos enfermeiros, atuantes nestas mesmas CCIHs, têm experiência superior à cinco anos, $57,1 \%$ e $75,0 \%$, respectivamente.

Detectamos ainda que nove desses mesmos enfermeiros, realizaram treinamento/curso em temas afetos à biossegurança, sendo que os profissionais foram treinados em maior proporção nos hospitais privados $(57,1 \%$ de um total de sete CCIHs), e nos hospitais filantrópicos (50,0\% de um total de quatro $\mathrm{CCIHs})$, a despeito dos hospitais públicos, cuja percentagem de enfermeiros das respectivas CCIHs treinados foi de $37,5 \%$ de um total de oito. 
Apenas três, das vinte e cinco instituições (12\%), uma de médio porte (filantrópica) e duas de grande porte (uma pública e uma filantrópica), possuem grupo executor de controle de infecção hospitalar. As composições desses mesmos grupos restringem-se basicamente ao enfermeiro atuando em dedicação integral (36 horas semanais) e um médico em dedicação parcial para cada um dos hospitais filantrópicos, um com quatro e outro com vinte horas de trabalho semanais, respectivamente.

Nenhuma das vinte e cinco instituições estudadas possui serviço médico ocupacional ou assemelhado e somente três hospitais (12\%), possuem Comissão Interna de Prevenção de Acidentes (CIPA) e em uma dessas CIPAS pelo menos um de seus membros realizaram curso/treinamento em biossegurança.

\subsection{Presença de normas, treinamentos, registros, rotinas e infra estrutura física relativas à biossegurança.}

No que se refere aos demais itens aqui considerados para a configuração de uma adequada estrutura de biossegurança, inicialmente, apresentamos os resultados relativos à sua presença nas instituições em geral (Tabela 5) e depois a discriminação por tipos de hospitais. 
Tabela 5 - Número e percentual de hospitais de acordo com a Presença das características pesquisadas, relativas à estrutura de biossegurança. Itabuna-BA, 2001.

\begin{tabular}{|c|c|c|}
\hline \multirow[b]{2}{*}{$\begin{array}{l}\text { PRESENÇA DE NORMAS, TREINAMENTOS, REGISTROS, } \\
\text { ROTINAS E ISOLAMENTOS. }\end{array}$} & \multicolumn{2}{|c|}{$N=25$ hospitais } \\
\hline & N. ${ }^{\circ}$ & $\%$ \\
\hline \multicolumn{3}{|l|}{ 1. NORMAS ESCRITAS } \\
\hline Precauçôes padrão & 3 & 12,0 \\
\hline Precauçōes baseadas na transmissão & 2 & 8,0 \\
\hline $\begin{array}{l}\text { Condutas frente aos casos de acidentes com materiais pérfuro- } \\
\text { cortantes }\end{array}$ & 8 & 32,0 \\
\hline \multicolumn{3}{|l|}{ 2. TREINAMENTO DE PESSOAL } \\
\hline Para as precauções padrão & 10 & 40,0 \\
\hline Para as precauções baseadas na transmissão & 9 & 36,0 \\
\hline Triagem precoce de pacientes suspeitos de TB & 0 & 0,0 \\
\hline \multicolumn{3}{|l|}{ 3. REGISTRO } \\
\hline Presença de mapas de risco & 0 & 0,0 \\
\hline Presença de Registro de acidentes com materiais pérfuro-cortantes & 7 & 28,0 \\
\hline Presença de Registro de cobertura de vacinaçâo para hepatite B & 5 & 20,0 \\
\hline \multicolumn{3}{|l|}{$\begin{array}{l}\text { 4. ROTINAS DE ATENCCAO MÉDICA ADMISSIONAL } \\
\text { EIMUNIZAÇAO DOS PROFISSIONAIS }\end{array}$} \\
\hline Realização de exame médico admissional & 7 & 28,0 \\
\hline Imunização dos profissionais para hepatite $B$ & 11 & 44,0 \\
\hline Realização de PPD periódico & 0 & 0,0 \\
\hline \multicolumn{3}{|l|}{ 5. ISOLAMENTO DE PACIENTES } \\
\hline Prática de se isolar paciente suspeito de TB & 19 & 76,0 \\
\hline Existência de adequadas acomodaçôes para isolamento & 0 & 0.0 \\
\hline
\end{tabular}

Observamos, pelos resultados encontrados, baixos percentuais afirmativos para a existência de normatizações escritas relativas à biossegurança, consideradas para fins do estudo nas instituições. Chama a atenção o fato de vinte e dois hospitais (88\%) não disporem sequer das normas concernentes às precauções padrão. Resultado ainda mais modesto ocorre com as normas relativas às precauções baseadas na transmissão, ausentes em vinte e três nosocômios (92\%).

As normas referentes às condutas frente aos casos de acidentes de profissionais com materiais pérfuro-cortantes, embora presentes em número maior de instituições que as demais, têm, também, tímida presença nos serviços hospitalares (oito instituições $32 \%)$.

Por outro lado, quando se avalia a realização de treinamento de pessoal para as precauções padrão, verificamos, muito embora com percentuais também modestos, contrariamente à existência de normas escritas nas mesmas instituições (12\%), 
referência afirmativa em percentual de $40 \%$ dos hospitais. O mesmo fenômeno é observado para as precauções baseadas na transmissão, cujo percentual de realização de treinamento chega a $36 \%$. O preparo de pessoal para triagem precoce de pacientes suspeitos de tuberculose, em contrapartida, não é praticado em nenhum dos hospitais estudados.

No que diz respeito ao item registros, observamos a ausência de mapa de risco em todas as instituições, presença de registro de casos de acidentes ocupacionais com materiais pérfuro-cortantes em sete $(28 \%)$, dos vinte e cinco hospitais e registro de cobertura da vacinação para hepatite $\mathrm{B}$ ausente em $20(80 \%)$ dos nosocômios.

De igual modo, a realização/exigência de exame médico admissional é rotina pouco freqüente nas instituições: sete $(28 \%)$ dos hospitais a tem institucionalizada, ao passo que a imunização dos profissionais para hepatite B é admitida por onze (44\%) dos serviços, cabendo, todavia, a observação citada por todos os enfermeiros que responderam às questões postas, de que a vacinação, ainda que acompanhada pelos respectivos responsáveis nas instituições, ocorre sob a égide das determinações da Sétima Diretoria Regional de Saúde, ou seja, constitui-se em prática nos hospitais, mas não exatamente como de sua própria iniciativa. Exames de PPD de profissionais atuantes no hospital não é realizado em nenhuma das instituições.

Verificamos referência positiva à implementação de isolamento para pacientes suspeitos de tuberculose em dezenove serviços hospitalares (76\%). Note-se que em nenhuma das instituições se dispõe de acomodações para isolamento de pacientes.

Na próxima tabela demonstramos a presença dos itens ora discriminados, de acordo com as diferentes características hospitalares. 
Tabela 6 - Presença de itens relativos à biossegurança nos hospitais, de acordo com características institucionais: Porte, Vinculação administrativo-financeira, Categoria, Localização geográfica, constituir-se em Campo de Ensino e Presença de CCIH. Itabuna-Ba. 2001.

\begin{tabular}{|c|c|c|c|c|c|c|c|c|c|c|c|c|c|c|c|c|c|c|c|c|c|c|c|c|c|c|c|c|}
\hline \multirow{3}{*}{$\begin{array}{c}\begin{array}{c}\text { Presença de } \\
\text { normas, } \\
\text { treinamentos, } \\
\text { registros e } \\
\text { rotinas }\end{array} \\
\text { Normas escritas } \\
\end{array}$} & \multicolumn{6}{|c|}{ Porte } & \multicolumn{6}{|c|}{$\begin{array}{l}\text { Vinculação } \\
\text { Administrativo-Financeiro }\end{array}$} & \multicolumn{4}{|c|}{ Natureza do atendimento } & \multicolumn{4}{|c|}{$\begin{array}{l}\text { Localização } \\
\text { Geográfica }\end{array}$} & \multicolumn{4}{|c|}{$\begin{array}{l}\text { Hospital } \\
\text { Campo de Ensino }\end{array}$} & \multicolumn{4}{|c|}{$\begin{array}{l}\text { Presença } \\
\text { de } \mathrm{CClH}\end{array}$} \\
\hline & \multicolumn{2}{|c|}{$P(n=14)$} & \multicolumn{2}{|c|}{$M(n=9)$} & \multicolumn{2}{|c|}{$G(n=2)$} & \multicolumn{2}{|c|}{$P(n=12)$} & \multicolumn{2}{|c|}{$P R(n=7)$} & \multicolumn{2}{|c|}{$F(n=6)$} & \multicolumn{2}{|c|}{$\begin{array}{c}\text { Geral } \\
(n=22)\end{array}$} & \multicolumn{2}{|c|}{$\begin{array}{c}\text { Especializada } \\
(n=3)\end{array}$} & \multicolumn{2}{|c|}{\begin{tabular}{|l|} 
Itabuna \\
$(n=8)$
\end{tabular}} & \multicolumn{2}{|c|}{$\begin{array}{l}\text { Outras } \\
(n=17)\end{array}$} & \multicolumn{2}{|c|}{$\begin{array}{l}C E \\
(n=4)\end{array}$} & \multicolumn{2}{|c|}{$\begin{array}{l}\text { Não CE } \\
(n=21)\end{array}$} & \multicolumn{2}{|c|}{$\begin{array}{l}\mathrm{C} / \mathrm{CCIH} \\
(n=19)\end{array}$} & \multicolumn{2}{|c|}{$\begin{array}{l}\mathrm{S} / \mathrm{CClH} \\
(n=6)\end{array}$} \\
\hline & $\mathrm{N}$ & $\%$ & $\mathrm{~N}$ & $\%$ & $\mathrm{~N}$ & $\%$ & $\mathrm{~N}$ & $\%$ & $\mathrm{~N}$ & $\%$ & $\mathrm{~N}$ & $\%$ & $\mathrm{~N}$ & $\%$ & $\mathrm{~N}$ & $\%$ & $\mathrm{~N}$ & $\%$ & $\mathrm{~N}$ & $\%$ & $\mathrm{~N}$ & $\%$ & $\mathrm{~N}$ & $\%$ & $\mathrm{~N}$ & $\%$ & $\mathrm{~N}$ & $\%$ \\
\hline Precauçōes Padrāo & 1 & 7,1 & $T$ & 11,1 & 1 & 50,0 & 2 & 16,7 & $\overline{0}$ & 0,0 & 1 & 16,7 & 3 & 13,6 & 0 & 0,0 & 2 & 25,0 & 1 & 5,9 & 2 & 50,0 & $T$ & 4,8 & 3 & 15,8 & 0 & 0,0 \\
\hline $\begin{array}{l}\text { Precauçōes baseadas } \\
\end{array}$ & 0 & 0,0 & 1 & 11,1 & 1 & 50,0 & 1 & 8,3 & 0 & 0,0 & 1 & 16,7 & 2 & 9,1 & 0 & 0,0 & 2 & 25,0 & 0 & 0,0 & 2 & 50,0 & 0 & 0,0 & 2 & 10,5 & 0 & 0,0 \\
\hline $\begin{array}{l}\text { Condutas frente aos } \\
\text { casos de acidentes } \\
\text { com materiais } \\
\text { pérfuro-cortantes }\end{array}$ & 2 & 14,3 & 5 & 55,5 & 1 & 50,0 & 1 & 8,3 & 2 & 28,6 & 5 & 83,3 & 6 & 27,3 & 2 & 66,7 & 3 & 37,5 & 5 & 29,4 & 3 & 75,0 & 5 & 23,8 & 0 & 31,6 & 2 & 33,3 \\
\hline \multicolumn{29}{|l|}{ Treinamentos } \\
\hline Precauçōes Padrāo & 4 & 28,6 & 4 & 44,4 & 2 & 100,0 & 4 & 33,3 & 2 & 28,6 & 4 & 66,7 & 8 & 36,4 & 2 & 66,7 & 4 & 50,0 & 6 & 35,3 & 3 & 75,0 & 7 & 33,3 & 8 & 42,1 & 2 & 33,3 \\
\hline $\begin{array}{l}\text { Precauçōes baseadas } \\
\text { na transmissāo }\end{array}$ & 5 & 35,7 & 3 & 33,3 & 1 & 50,0 & 3 & 25,0 & 3 & 42,8 & 3 & 50,0 & 8 & 36,4 & 1 & 33,3 & 3 & 37,5 & 6 & 35,2 & 3 & 75,0 & 6 & 28,6 & 9 & 47,4 & 0 & 0,0 \\
\hline $\begin{array}{l}\text { Triagem precoce de } \\
\text { paciente suspeito de } \\
\text { tuberculose }\end{array}$ & 0 & 0,0 & 0 & 0,0 & 0 & 0,0 & 0 & 0,0 & 0 & 0,0 & 0 & 0.0 & 0 & 0,0 & 0 & 0,0 & 0 & 0,0 & 0 & 0,0 & 0 & 0,0 & 0 & 0,0 & 0 & 0,0 & 0 & 0,0 \\
\hline \multicolumn{29}{|l|}{ Registros } \\
\hline Mapa de risco & 0 & 0,0 & 0 & 0,0 & 0 & 0,0 & 0 & 0,0 & 0 & 0,0 & 0 & 0,0 & 0 & 0,0 & 0 & 0,0 & 0 & 0,0 & 0 & 0,0 & 0 & 0,0 & 0 & 0,0 & 0 & 0,0 & 0 & 0,0 \\
\hline $\begin{array}{l}\text { Registro de acidentes } \\
\text { de profissionais } \\
\text { c/materiais pérfuro- } \\
\text { cortantes }\end{array}$ & 2 & 14,3 & 4 & 44,4 & 1 & 50,0 & 3 & 25,0 & $\underline{2}$ & 28,6 & 2 & 33,3 & 6 & 27,3 & 1 & 33,3 & 4 & 50,0 & 3 & 17,6 & 3 & 75,0 & 4 & 19,0 & 7 & 36,8 & 0 & 0,0 \\
\hline $\begin{array}{l}\text { Registro de cobertura } \\
\text { vacinal para hepatite } \\
\text { B }\end{array}$ & 2 & 14,3 & 2 & 22,2 & 1 & 50,0 & 3 & 25,0 & 2 & 28,6 & 0 & 0,0 & 4 & 18,2 & 1 & 33,3 & 3 & 37,5 & 2 & 11,8 & 1 & 25,0 & 4 & 19,0 & 4 & 21,0 & 1 & 16,7 \\
\hline \multicolumn{29}{|l|}{$\begin{array}{l}\text { Atenção médica } \\
\text { admissional/Rotinas } \\
\text { de imunizaçấo }\end{array}$} \\
\hline $\begin{array}{l}\text { Exame médico } \\
\text { Admissional }\end{array}$ & 4 & & 2 & 22,2 & 1 & 50,0 & $T$ & 8,3 & 3 & 42,8 & 3 & 50,0 & 5 & 22,7 & 2 & 66,7 & 4 & 50,0 & 3 & 17,6 & 3 & 75 & 4 & 19,0 & 7 & 36,8 & $\overline{0}$ & 0,0 \\
\hline $\begin{array}{l}\text { Imunização para } \\
\text { hepatite B }\end{array}$ & 4 & 28,6 & 5 & 55,5 & 2 & 100,0 & 4 & 33,3 & 3 & 42,8 & 4 & 66,7 & 8 & 36,4 & 3 & 100,0 & 5 & 62,5 & 6 & 35,3 & 4 & 100,0 & 7 & 33,3 & 8 & 42,1 & 3 & 50,0 \\
\hline PPD periodico & 0 & 0,0 & 0 & 0,0 & 0 & 0,0 & 0 & 0,0 & 0 & 0,0 & 0 & 0,0 & 0 & 0,0 & 0 & 0,0 & 0 & 0,0 & 0 & 0,0 & 0 & 0,0 & 0 & 0,0 & 0 & 0,0 & 0 & 0,0 \\
\hline Porte: $P=$ pequeno & & & & io porte & & $G=$ gral & nde $\mathrm{p}$ & & & & & & culaç & $\Lambda \mathrm{dm}$ & isstrati & -finar & eiro: & $=$ púb & & & $P R$ & privado & & & 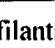 & ópico & & \\
\hline
\end{tabular}


Quando analisamos a existência de normas escritas nos hospitais estratificados por porte, verificamos que aquelas relativas às precauções padrão estão presentes em um $(50,0 \%)$ dos hospitais de grande porte, em um $(11,1)$ dos hospitais de médio porte e uma $(7,1)$ das instituições pequenas. As normas escritas relativas às precauções baseadas na transmissão estão presentes em um $(50,0 \%)$ dos hospitais de grande porte, em um $(11,1 \%)$ dos serviços de médio porte e em nenhum dos hospitais pequenos. Existem condutas frente aos acidentes com materiais pérfuro-cortantes, em um hospital grande $(50,0 \%)$, em cinco $(55,5 \%)$ hospitais médios e em dois $(14,3 \%)$ hospitais de pequeno porte.

Procedido tratamento estatístico, demonstram-se diferenças estatisticamente significativas em nivel de $7 \%(p=0,07)$, quando os hospitais são subdivididos por porte, quanto a existência de normas relativas às precauções baseadas na transmissão, quando essa é analisada isoladamente. Verifica-se também diferença estatisticamente significante ao mesmo nivel para a existência do conjunto de normas escritas, com melhores resultados para os hospitais grandes, seguidos pelos de médio e pequeno porte.

As normas relativas às precauções universais/padrão e baseadas na transmissão, quando estudadas nos hospitais distribuídos quanto ao seu status financeiro, inexistem nos hospitais privados, estão presentes, a primeira em duas instituições públicas $(16,7 \%) \mathrm{e}$ em um hospital filantrópico $(16,7 \%)$ e a segunda em igual número de hospitais públicos( um hospital- 8.3\%) e filantrópicos(um hospital-16,7\%). As condutas frente a acidentes de profissional vítima de material pérfuro-cortante aparecem em cinco $(83,3 \%)$ dos hospitais filantrópicos, em dois $(28,6 \%)$ dos hospitais privados e apenas em um $(8,3 \%)$ dos hospitais públicos.

Demonstram-se diferenças estatisticamente significativas em nível de $2 \%(p=0,02)$ para o conjunto de normas escritas entre as categorias de hospitais, com melhores performances para as instituições filantrópicas, seguidas pelos hospitais privados e, por último, os públicos. Quando se analisa as questões isoladamente, não se detecta, todavia, diferença estatisticamente significante para a existência das normas de precaução universal/padrão e para as precauções baseadas na transmissão, mas 
diferença estatisticamente significante em nível de $0,005 \%(p=0,00005)$ para as condutas frente aos acidentes com materiais pérfuro-cortantes, detendo resultados mais satisfatórios os hospitais filantrópicos (cinco das seis instituições dispõem das referidas normas).

Agrupados pela caracteristica de se constituir ou não em campo de práticas para atividades de cursos de graduação e ensino médio de enfermagem, bem como residência médica, níveis de ensino presentes na região, os hospitais demonstram-se com diferenças significativas em nivel de $0,4 \%(p=0,004)$ para o conjunto de normas escritas, com melhores resultados para os hospitais do primeiro grupo. Analisadas as questões isoladamente, detectamos diferenças estatisticamente significativas em nível de $6 \%(p=0,06)$, quando se atém às precauções universais/padrão, em $2 \%(p=0,02)$ para as precauções baseadas na transmissão e $8 \%(p=0,08)$ para a presença de normas escritas concernentes às condutas frente aos acidentes com materiais pérfuro-cortantes entre os dois grupos de hospitais aqui considerados.

Verificamos, igualmente, diferença estatisticamente significante no nível de $6 \%$ $(p=0,06)$ para o conjunto de questões relativas à existência de normas escritas nos hospitais, quando esses são separados conforme sua localização geográfica, considerada como situados na cidade pólo da região, Itabuna, ou fora dela. As instituiç̃oes aí localizadas, apresentam desempenho melhor do que aquelas localizadas nos demais municípios.

Ao analisar a presença de normas escritas em hospitais com e sem comissão de controle de infecção hospitalar, verificamos que três $(15,8 \%)$, das instituições com $\mathrm{CCIH}$, dispõem das normas relativas às precauções universais/padrão e duas $(10,5 \%)$ têm normas para as precauções baseadas na transmissão, e em seis (31,6\%), encontram-se, por escrito, as condutas frente aos casos de acidentes de profissionais do hospital com materiais pérfuro-cortantes. 
Resultados ainda mais modestos são encontrados nos hospitais que não têm formalmente constituído o citado órgão, cujos percentuais são de $0 \%$ para as precauções universais/padrão e baseadas na transmissão e 33,3\% para as condutas frente aos casos de acidentes com materiais pérfuro-cortantes. Todavia, não existem diferenças estatisticamente significativas, pelos testes empreendidos entre os dois grupos de hospitais, não somente para as questões consideradas individualmente, mas também para o grupo de questões concernentes às normas escritas no conjunto aqui considerado.

Por outro lado, quando separamos os hospitais de acordo com a existência de grupo executor de controle de infecção hospitalar, detectamos diferença estatisticamente significante no nível de $1 \%(p=0,01)$ para o conjunto de normas escritas, com melhor desempenho para os hospitais providos dos respectivos serviços e também para os subitens precauções universais/padrão, no nível de 3\% $(p=0,03)$, e precauções baseadas na transmissão, no nível de $1 \%(p=0,01)$. Contudo, no que concerne às condutas frente aos acidentes de profissionais dos hospitais com materiais pérfuro-cortantes, analisadas isoladamente, não ocorre, com diferença estatisticamente significante entre os hospitais subdivididos, de igual modo, com e sem o respectivo grupo.

Características outras dos hospitais, como seu corpo clínico constituir-se aberto ou fechado, clientela atendida, se do SUS ou de convênios privados, pagamentos particulares, bem como predomínio dessa mesma clientela não separam os hospitais de forma estatisticamente significante para o item existência das normas escritas aqui consideradas.

Também os hospitais classificados em gerais e especializados para o mesmo item existência de normas escritas - não se mostram com diferenças significativas pelos testes empreendidos. Chama a atenção a inexistência nos hospitais especializados de normas escritas para as precauções padrão e precauções baseadas na transmissão.

Por outro lado, ao investigar a realização de treinamentos acerca das principais medidas de biossegurança para agentes biológicos nos hospitais subdivididos por porte. verificamos que as duas únicas instituições grandes realizaram treinamento de pessoal para as precauções universais/padrão, ao passo que os mesmos treinamentos ocorreram 
em quatro $(44,4 \%)$ dos hospitais médios em termos de número de leitos e quatro $(28,6 \%)$ dos serviços hospitalares de pequeno porte.

Os treinamentos para as precauções baseadas na transmissão, em contrapartida, foi referido afirmativamente em cinco $(35,7 \%)$ das instituições de pequeno porte, três $(33,3 \%)$ dos hospitais médios e em um $(50,0 \%)$ dos de grande porte. Nenhuma instituição desenvolveu/desenvolve treinamento de pessoal para triagem precoce de pacientes suspeitos de tuberculose.

Não se demonstra, ainda, diferenças estatisticamente significantes dentre os grupos de hospitais para as questões afetas ao treinamento como um todo, bem como para os subitens considerados individualmente (precauções universais/padrão, precauções baseadas na transmissão e triagem precoce de pacientes suspeitos de tuberculose), ainda que as médias apontem uma ligeira tendência de resultados pouco mais promissores, pelo menos para as precauções padrão, nos hospitais de grande e médio porte.

Considerando as instituições classificadas em respeito ao seu status financeiro, verificamos, para a realização de treinamentos, os seguintes resultados: quatro $(66,7 \%)$ dos hospitais filantrópicos realizaram treinamento para as precauções padrão e três $(50,0 \%)$ para as precauções baseadas na transmissão. Nos hospitais privados, os percentuais de realização de treinamentos foram de dois $(28,6 \%)$, para as precauções padrão e três $(42,8 \%)$, para as precauções baseadas na transmissão. Por fim, quatro $(33,3 \%)$ dos doze hospitais públicos treinaram seu pessoal para as precauções padrão $\mathrm{e}$ três $(25,0 \%)$ para as precauções baseadas na transmissão.

Observamos, ao analisar o conjunto das questões atinentes à realização de treinamentos para as precauções em tela, não haver diferenças estatisticamente significantes para os hospitais categorizados por vinculação administrativo financeira, embora haja tendência de melhores resultados para os hospitais filantrópicos.

Por outro lado, as instituições hospitalares se apresentam de forma diferente com significância estatística ao nível de $4 \%(p=0,04)$, para o conjunto de itens referentes a treinamento de pessoal para as precauções relativas à biossegurança , quando separadas 
pela característica de se constituir ou não em campo de ensino. Para a análise em separado das questões, detectamos diferenças estatisticamente significantes no nível de $12 \%(p=0,12)$, com resultados mais favoráveis aos hospitais campo de ensino, para as precauções baseadas na transmissão.

Não se diferenciam os hospitais com e sem $\mathrm{CCIH}$, para o item treinamento no seu conjunto, ainda que os percentuais apontem para uma ligeira tendência de melhores resultados em favor do primeiro grupo.

As instituições agrupadas segundo a existência ou não de grupo executor de controle de infecção hospitalar, em contrapartida, diferenciam-se no nível de 6\% $(p=0,06)$ de significância estatística, com melhor desempenho para os primeiros quando analisados os subitens no seu conjunto, e em $5 \%(p=0,05)$, quando se analisa isoladamente a realização de treinamentos para as precauções padrão.

Da mesma forma à existência de normas escritas, também a realização de treinamentos não ocorre de forma distinta estatisticamente nos serviços hospitalares quando levadas em conta as suas características como corpo clínico aberto ou fechado, clientela atendida (se SUS ou convênio privado e pagamento particular), predomínio da clientela, bem como sua localização geográfica.

No que diz respeito à presença dos itens relativos a registros, quais sejam a existência de mapas de risco institucionais, anotação de acidentes de profissionais com materiais pérfuro-cortantes e documentação de cobertura vacinal para a hepatite $\mathrm{B}$, analisados em conjunto, que, conforme já citado na descrição dos hospitais em geral, constituem-se, a exemplo dos demais, em práticas pouco freqüentes, não se detecta, ainda, não obstante em proporções diversas, ocorrerem diferenças estatisticamente significativas entre os vários grupos de serviços hospitalares. Exceções feitas às instituições agrupadas em com e sem grupo executivo de controle de infecção hospitalar, as quais se apresentam com diferenças estatisticamente significantes no nivel de $4 \%(p=0,04)$, detendo melhor desempenho o primeiro grupo; aos hospitais localizados na cidade de Itabuna e em outros municípios com diferenças estatisticamente significantes ao mesmo nível de significância, mais bem posicionadas as instituições localizadas em Itabuna e as 
instituições com e sem $\mathrm{CCIH}$ com diferenças estatisticamente significativas no nível de $13 \%(p=0,13)$.

$\mathrm{Na}$ análise individual de cada uma das questões supra mencionadas, detectamos, em contraponto, diferenças estatisticamente significantes no nível de $7 \%(p=0,07)$, para o subitem registro de acidentes com materiais pérfuro-cortantes, quando os hospitais são caracterizados por tamanho em termos de número de leitos. Melhores resultados são apresentados pelos hospitais grandes, seguidos dos de médio e pequeno porte.Também apresentam diferenças estatisticamente significativas (aqui ao nivel de $5 \%-p=0,05$ ) para o subitem, os hospitais classificados segundo campo de ensino, com melhores resultados para os que se prestam às referidas atividades. O mesmo ocorre quando os hospitais são subdivididos em com e sem grupo executor de I H [1,5\% de significância $(p=0,015)]$. Observa-se, adicionalmente, haver diferenças estatisticamente significantes no nivel de $14 \%(p=0,14)$ quando os hospitais são agrupados segundo a existência de CCIH.

Acerca das rotinas de imunização, realização de exame médico admissional e controle de PPD periódico de profissionais envolvidos na prática assistencial em área de risco para tuberculose, os resultados encontrados, conforme já citado, quando da apresentação da presença dos itens no geral, mostram-se também pouco promissores. Os hospitais, contudo, apresentam-se com diferenças significativas no nivel de $3 \%(p=0,03)$ para as questões agrupadas, quando são categorizados em constituir-se ou não em campo de ensino e com e sem grupo executor de controle de infecção hospitalar, com melhores resultados para os primeiros respectivamente. $E$, ainda, no mesmo nível de significância, as instituições classificadas segundo tipo de atendimento geral ou especializado, com melhores performances para os segundos.

Convém destacar, mais uma vez, que nenhuma das instituições visitadas, ainda que em sua maioria incluam no seu atendimento prontos socorros, ambulatórios e unidades de clínica médica, realizam ou tem registro de já ter sido realizado PPD de seus funcionários e apenas sete instituições (28\%) afirmam realizar ou exigir exame médico admissional de seus profissionais, sendo, ainda, essa prática mais comum, 
proporcionalmente, nos hospitais privados e filantrópicos do que nos hospitais públicos embora uma análise mais aprofundada seja prejudicada pela modéstia amostral. No que concerne à análise por porte dos hospitais, as proporções de realização do mesmo exame são praticante coincidentes entre os grupos.

Apesar de não se detectar diferenças estatisticamente significativas, podemos verificar também para a referência à rotina de imunização para a hepatite $B$, freqüência maior do quesito, nos hospitais privados e filantrópicos a despeito das próprias entidades públicas.

Mostram-se, por outro lado, para o mesmo item, com resultados mais promissores e com diferenças estatísticas no nível de $3 \%(p=0,03)$, os hospitais campo de ensino. Também as instituições classificadas em gerais e especializadas, apresentam-se com diferenças estatisticamente significativas, mas ao nivel de $7 \%(p=0,07)$. Nos hospitais especializados estão mais presentes rotinas de vacinação para hepatite $B$ do quadro funcional, quando comparados com os hospitais gerais.

Verifica-se, de igual modo, melhores resultados, com diferenças significativas ao mesmo nível de $7 \%$ de significância, para o aspecto relativo à existência de rotinas de imunização, quando as instituições dispõem de grupo executor de controle de $\mathrm{IH}$.

Corpo clínico aberto ou fechado, tipo de clientela atendida, presença de CCIH, localização geográfica das instituições, não distinguem os hospitais para as variáveis ora analisadas, tanto no que concerne ao seu conjunto, quanto para cada item tomado individualmente.

Com referência ao tópico em que foram abordadas as questões da instituição de isolamento para pacientes suspeitos de tuberculose e a existência de infra-estrutura para isolamentos para doenças transmissíveis, detectamos que o primeiro item (prática de isolar pacientes suspeitos de tuberculose) foi referido em dezenove instituições (76\% dos hospitais), sem distinções estatisticamente significativas entre os diversos agrupamentos de serviços hospitalares utilizados para fins do estudo. Por fim, conforme 
já citado, nenhum hospital dispõe de acomodações para isolamento de pacientes com doenças transmissiveis.

\subsubsection{Os hospitais de acordo com a presença do conjunto geral de itens considerados para fins do estudo.}

Apresentamos aqui os resultados dos testes empreendidos em relação à presença do conjunto geral dos itens levados em conta no estudo (Quadro 1), de acordo com as respectivas classificações dos hospitais. Apresenta-se depois individualmente cada uma das instituições com suas características e o percentual de existência dos itens considerados.

Desse modo, das características utilizadas para classificar as instituições quando avaliada a aquiescência, em conjunto, a todos os itens elencados para uma estrutura de biossegurança para agentes biológicos na prática assistencial em hospital, a relativa à sua esfera administrativo-financeira, demonstra resultados com diferenças estatisticamente significativas no nivel de 7\% $(p=0,07)$, pelos testes empreendidos. Os hospitais filantrópicos aparecem com resultados um pouco melhores - $75 \%$ dos 6 hospitais teve presença média dos itens superior à mediana obtida para o conjunto geral dos hospitais analisados $(+m=75 \%$ ) (quatro hospitais com valor superior e um com valor igual à mediana - valor = mediana, contagem $=0,5$ ) seguidos das instituições privadas $(+\mathrm{m}=64 \%)$ e, por último, das públicas $(+\mathrm{m}=25 \%)$.

Para a variável porte, detectamos diferenças estatisticamente significativas no nível de $11 \%(p=0,11)$, com tendência de crescimento das médias no sentido do aumento do tamanho das instituições em termos de número de leitos (Hospitais de grande porte, $+\mathrm{m}=100 \%$; Hospitais de médio porte, $+\mathrm{m}=55 \%$; Hospitais de pequeno porte $+\mathrm{m}=35 \%$ ).

As instituições que se constituem em campos de ensino prático para cursos de graduação em enfermagem, residência médica e ensino médio de enfermagem (cursos técnicos e de auxiliares) apresentam melhores resultados, com distinções estatisticamente significativas ao nivel de $2 \% \quad(p=0,02)$, comparando-se com os 
hospitais que não se prestam à essa atividade (Hospitais campos de ensino $+\mathrm{m}=100 \% \mathrm{e}$ não campos de ensino $+m=38 \%$ ).

Os hospitais quando agrupados por localização na cidade de Itabuna ou fora dela mostram-se com diferenças significativas no nível de $15 \%(p=0,15)$. As instituições localizadas na cidade em tela tiveram suas médias de presença de itens em valores acima da mediana $(+\mathrm{m})=68 \%$ e os localizados fora da cidade $+\mathrm{m}=38 \%$.

Por outro lado, não se verificam distinções estatisticamente significativas, porém, a presença média dos itens, indica que instituições que atendem a todos os pacientes no que se refere às fontes pagadoras pelos serviços prestados apresentam melhores resultados $(+m=68 \%)$ que aqueles que recebem apenas aos beneficiários do SUS $(+\mathrm{m}=40 \%)$ ou somente beneficiários de convênios privados e pagamentos particulares $(+\mathrm{m}=0 \%)$.

Corpo clínico aberto ou fechado não diferencia com significância estatística as instituições, como também o seu tipo de atendimento, se geral ou especializado, não diferencia, muito embora possamos dizer que estes últimos apresentem resultados menos modestos que os primeiros $(+\mathrm{m}=43 \%$ e $+\mathrm{m}=83 \%$ para os hospitais gerais e especializados respectivamente). Também a presença de $\mathrm{CCIH}$ não diferencia com significância estatística os hospitais $(+\mathrm{m}=52 \%$ para os hospitais com $\mathrm{CClH}$ e $+\mathrm{m}=33 \%$ daqueles sem $\mathrm{CClH})$.

A presença de grupo executor de controle de $\mathrm{IH}$, em contrapartida, diferencia estatisticamente no nivel de $3 \%$ de significância( $p=0,03)$, as instituições. Apreendem os melhores resultados, os hospitais dotados do grupo (Hospitais com grupo executor de controle de $\mathrm{IH}-+\mathrm{m}=100 \%$; hospitais sem grupo executor de controle de $\mathrm{IH}$ $+m=40 \%$ ).

Quanto à uma aproximação das instituições de uma situação que poderia se considerar como desejável no que se refere à uma estrutura de biossegurança para agentes biológicos na prática assistencial em hospitais, pelo menos no que tange à presença dos itens considerados para fins do estudo, os resultados mostram-se pouco promissores. 
Na tabela 7 ilustramos a frequêencia em percentagem de itens presentes em cada uma das instituiç̃es, em ordem decrescente e, na seqüência, podemos visualizar graficamente a distribuição dos hospitais categorizados pelas variáveis utilizadas no estudo e perfilados, com o contraponto de um hospital (figura sempre em preto), no qual todos os itens concernentes a estrutura aqui delimitada estariam presentes.

Tabela 7 - Porcentagem de itens presentes - existência de infraestrutura, normas e rotinas para biossegurança para agentes biológicos em cada um dos hospitais. Itabuna BA, 2001 .

\begin{tabular}{|c|c|c|c|c|c|c|c|c|}
\hline Hospital & $\begin{array}{l}\text { Porte } \cdot / \mathrm{N}^{\circ} \\
\text { de Leitos }\end{array}$ & $\begin{array}{c}\text { Esfera } \cdots \\
\text { Administrativa }\end{array}$ & \begin{tabular}{|l|} 
Tipo de \\
Hospital.....
\end{tabular} & $\begin{array}{c}\text { Clientela } \\
\text {..... }\end{array}$ & \begin{tabular}{|} 
Predominio \\
da Clientela \\
\end{tabular} & \begin{tabular}{|l|} 
Corpo \\
Clinico \\
\end{tabular} & \begin{tabular}{|c|} 
Localizaçào \\
.......*
\end{tabular} & $\begin{array}{c}\text { Percentual de } \\
\text { existência dos itens } \\
\text { considerados \% }\end{array}$ \\
\hline L. & $G(153)$ & $\bar{P}$ & $\bar{G}$ & $\mathrm{~S}$ & $S$ & $\mathrm{~F}$ & 1 & 66.7 \\
\hline $\mathrm{D}$. & $M(147)$ & $F$ & G & $T$ & C & $\mathrm{F}$ & 1 & 66.7 \\
\hline $\mathrm{O}$ & $P(12)$ & $\mathrm{P}$ & $\bar{G}$ & $S$ & $S$ & $\mathrm{~F}$ & 0 & 52,9 \\
\hline C & $P(24)$ & $\mathrm{Pr}$ & $\mathrm{G}$ & $S$ & $\mathrm{~s}$ & $F$ & $\mathrm{O}$ & 47,0 \\
\hline$T *$ & $G(175)$ & $F$ & $E$ & $T$ & $S$ & $\mathrm{~F}$ & 1 & 44,4 \\
\hline$G^{*}$ & $M(61)$ & $\mathrm{F}$ & $E$ & $\bar{S}$ & $\bar{S}$ & $\mathrm{~F}$ & 1 & 35,3 \\
\hline $\mathrm{U}$ & $M(70)$ & $\mathrm{Pr}$ & G & $S$ & $S$ & $A$ & l & 35,3 \\
\hline 1 & $P(50)$ & $\mathrm{F}$ & G & $T$ & $\mathrm{~S}$ & $F$ & $\mathrm{O}$ & 31,2 \\
\hline $\bar{E}$ & $M(53)$ & $\mathrm{P}$ & G & $S$ & $S$ & $\mathrm{~F}$ & $\mathrm{O}$ & 29,4 \\
\hline$k$ & $P(44)$ & $\mathrm{Pr}$ & $G$ & $T$ & $S$ & $F$ & $O$ & 29,4 \\
\hline A & $P(43)$ & $\mathrm{Pr}$ & $\bar{G}$ & $T$ & $S$ & $F$ & $\mathrm{O}$ & 29.1 \\
\hline$N$ & $M(70)$ & $\operatorname{Pr}$ & $E$ & $T$ & S & $\mathrm{F}$ & 1 & 23.5 \\
\hline $\mathrm{Z}$ & $M(110)$ & $F$ & $\mathrm{G}$ & $\mathrm{S}$ & $S$ & $F$ & $\mathrm{O}$ & 23,5 \\
\hline $\mathrm{J}$ & $P(30)$ & $P$ & G & $S$ & $S$ & $\mathrm{~F}$ & $\mathrm{O}$ & 18.7 \\
\hline$M$ & $P(30)$ & $P$ & G & $S$ & $S$ & $F$ & $\mathrm{O}$ & 18,7 \\
\hline$F$ & $P(50)$ & $\mathrm{Pr}$ & $\mathrm{G}$ & $\mathrm{PC}$ & $C$ & $A$ & 1 & 17,6 \\
\hline W & $M(68)$ & $\mathrm{P}$ & $G$ & $S$ & $\mathrm{~S}$ & $F$ & $\mathrm{O}$ & 17,6 \\
\hline $\bar{R}$ & $P(30)$ & $\mathrm{P}$ & $\bar{G}$ & $S$ & $S$ & $F$ & $O$ & 12,5 \\
\hline $\bar{x}$ & $M(110)$ & $\mathrm{Pr}$ & G & $T$ & C & $\mathrm{A}$ & 1 & 12,5 \\
\hline$S$ & $P(36)$ & $\mathrm{P}$ & $\overline{\mathrm{G}}$ & $S$ & $S$ & $\mathrm{~F}$ & $\mathrm{O}$ & 11.7 \\
\hline $\mathrm{V}$ & $P(24)$ & $\mathrm{P}$ & $\mathrm{G}$ & $S$ & $S$ & $\mathrm{~F}$ & $O$ & 11.7 \\
\hline $\mathrm{H}$ & $P(21)$ & $\mathrm{P}$ & $G$ & $S$ & $S$ & $F$ & $\bar{O}$ & 5,9 \\
\hline $\mathrm{B}$ & $P(42)$ & $P$ & $\bar{G}$ & $S$ & $S$ & $F$ & $\mathrm{O}$ & 0,0 \\
\hline $\mathrm{P}$ & $M(61)$ & $F$ & $G$ & $T$ & $S$ & $F$ & $\mathrm{O}$ & 0.0 \\
\hline $\bar{Q}$ & $P(17)$ & $P$ & $\mathrm{G}$ & $S$ & $S$ & $F$ & $\bar{O}$ & 0.0 \\
\hline
\end{tabular}

* Hospital Campo de estágio $\quad$ ** $\mathbf{P}=$ Pequeno; $\mathbf{M}=$ Médio; $\mathbf{G}=$ Grande $\quad * * * \mathbf{P}=$ Público; $\mathbf{P r}=$ Privado; $\mathbf{F}=$ Filantrópico $* * * * \mathrm{G}=$ Geral; $\mathrm{E}=$ Especializado ****** S=SUS: $C=$ Convenios

***** $\mathbf{T}=$ Todas (Particular. Convênios, SUS); $\mathbf{P}=$ Particular; $\mathbf{C}=$ Convènios *******A=Aberto, $\mathbf{F}=$ Fechado 


\section{Figura 2}

\section{Dispersão dos hospitais agrupados conforme porte -} Itabuna-Ba. 2001.

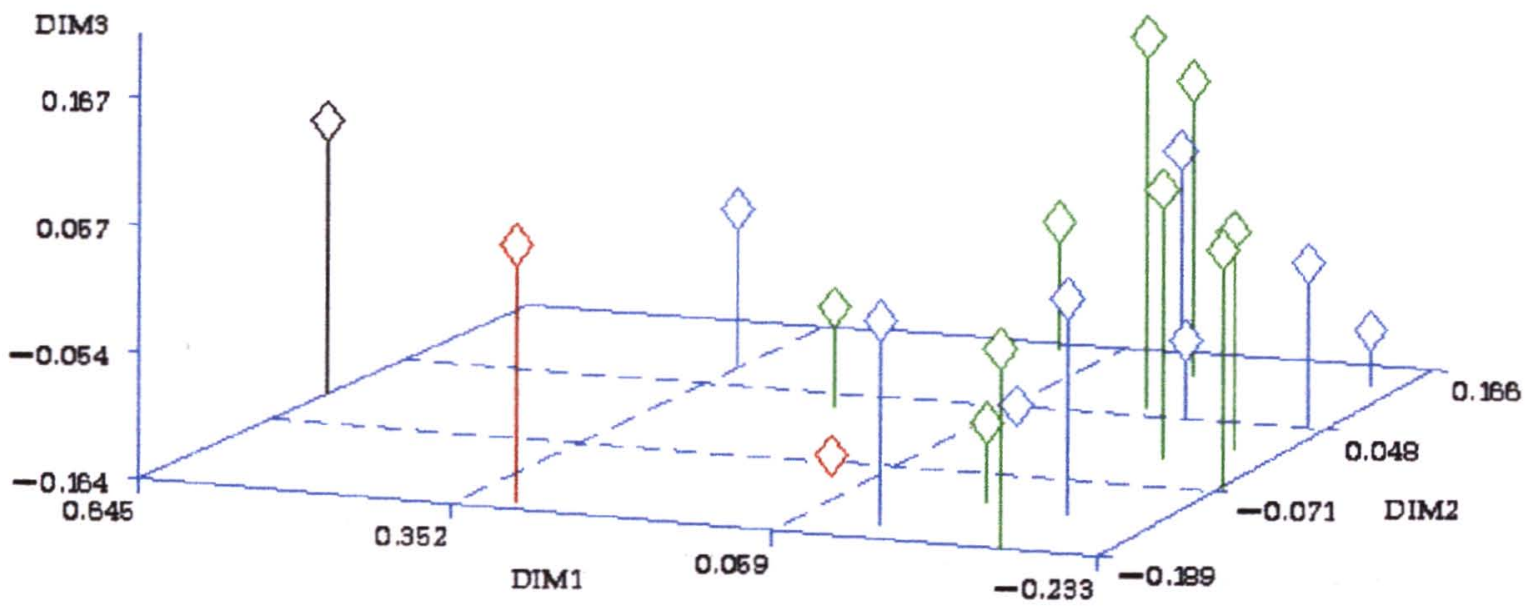

\section{Figura 3}

\section{Dispersão dos hospitais agrupados conforme vinculação administrativa/status financeiro - Itabuna-Ba. 2001.}

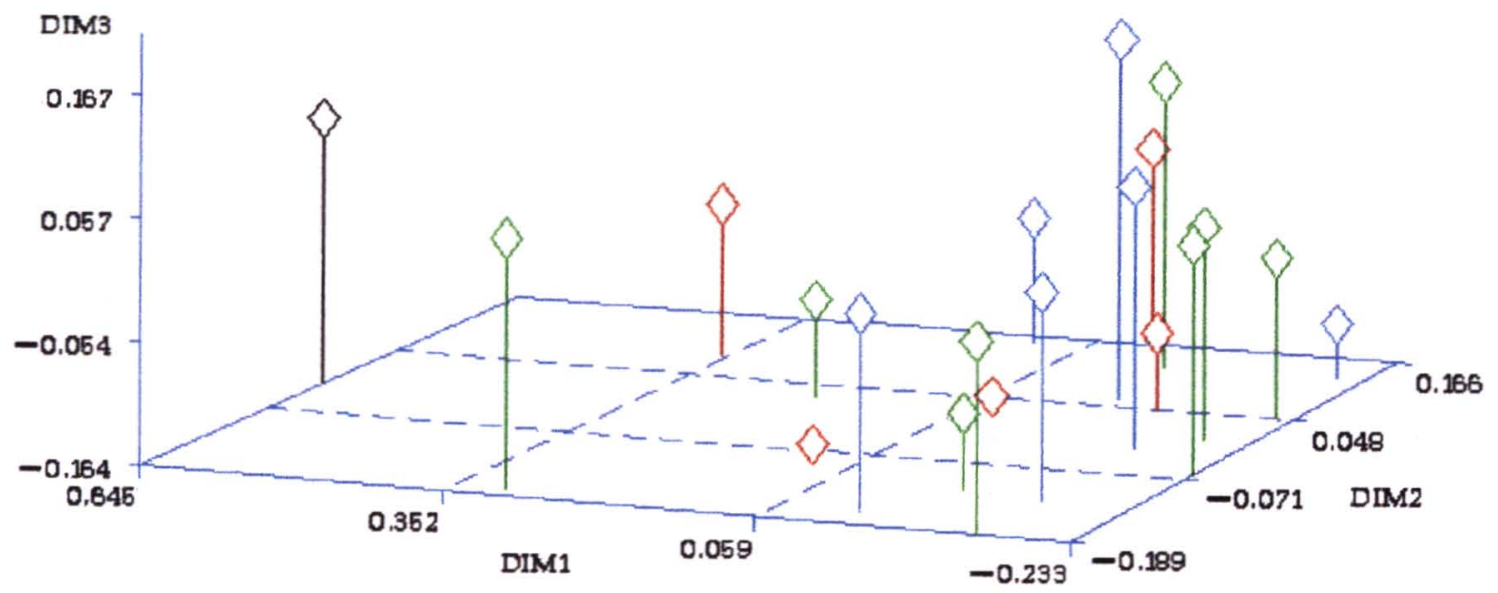

verde: publico - azul: privado.

vermelho: filantropico - preto: referencia coordenadas: PROC MDS - SAS. a Dartir da matriz de distancias simples. excluidos a hospitais B H P O. 
Figura 4

Dispersão dos hospitais agrupados conforme tipo de atendimento geral ou especializado - Itabuna-Ba, 2001.

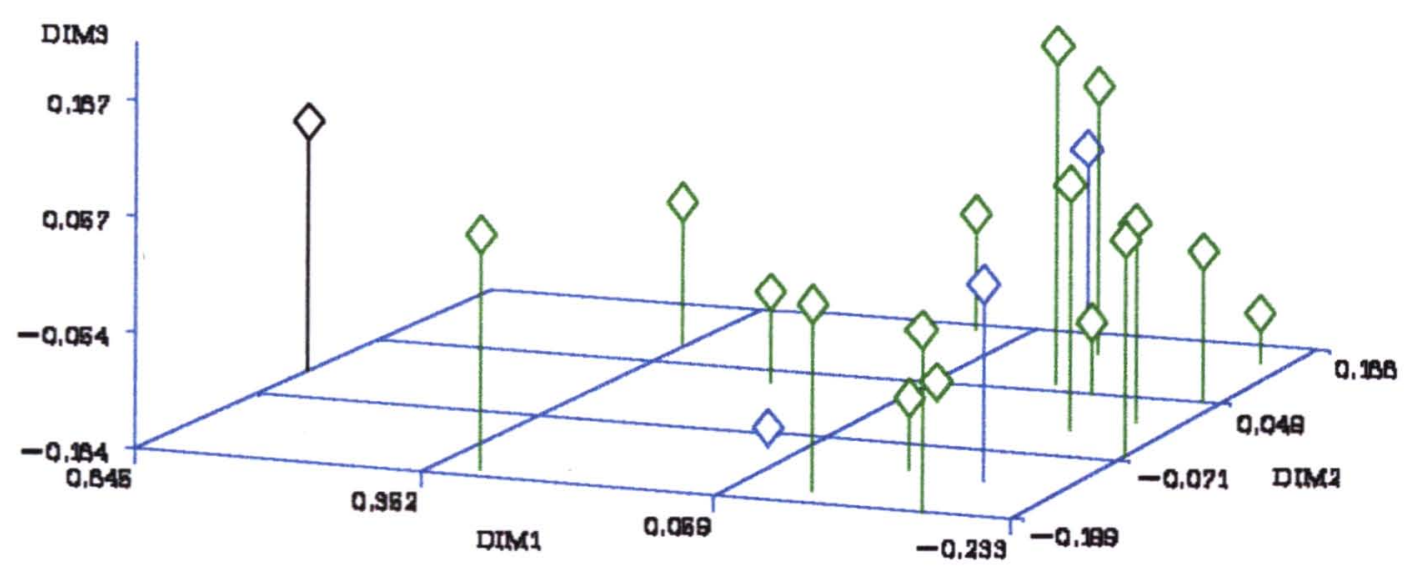

vardai garal - axuli espectaltzado.

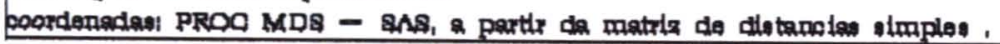

preto:

Figura 5

Dispersão dos hospitais agrupados conforme Tipo de Clientela atendida - Itabuna-Ba, 2001.

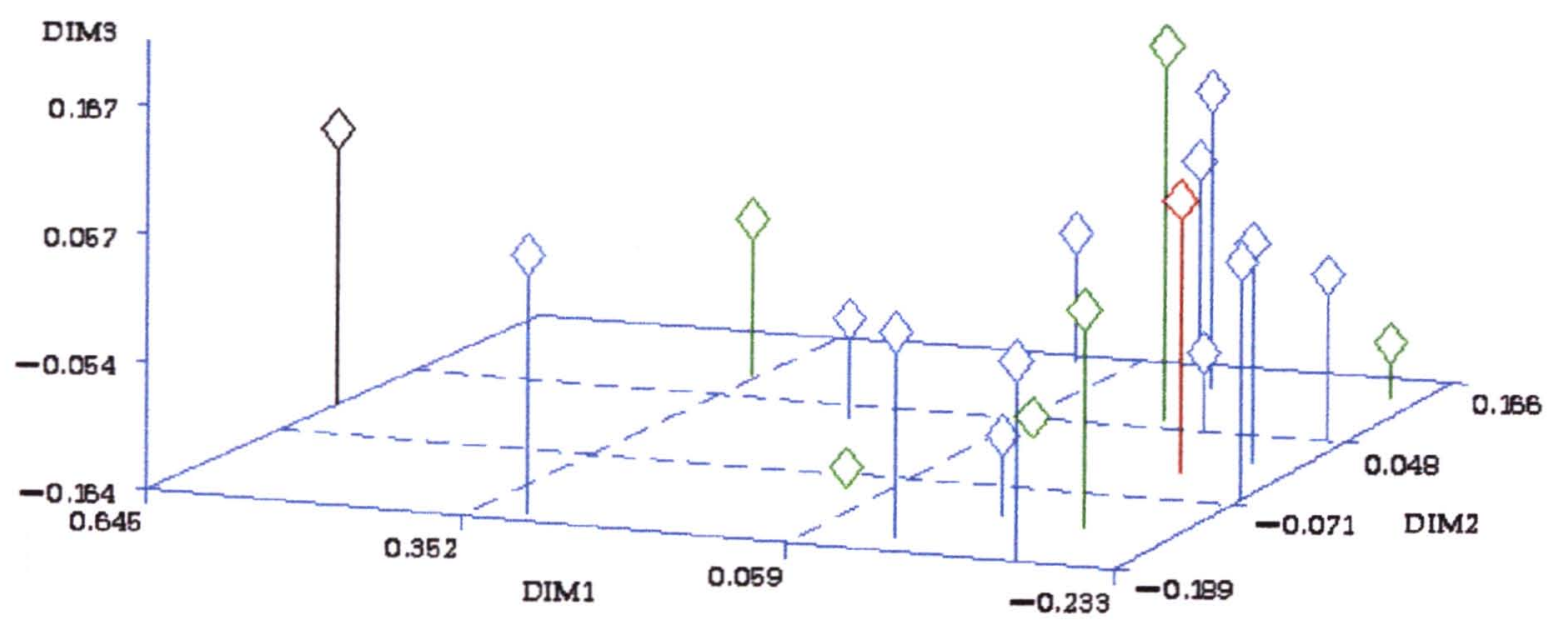

verde: geral - 2zul: sUS - vermelho: particular e convenios. 


\section{Figura 6}

\section{Dispersão dos hospitais agrupados conforme corpo clínico aberto / fechado - Itabuna-Ba. 2001.}



verde: aberto - azul: fechado.

preto: referencia.

coordenad2s: PROC MDS - 8A8, a partir da matriz de distancias simales. excluidos es hos pitais B H P O.

\section{Figura 7}

Dispersão dos hospitais agrupados conforme localização aeoaráfica - Itabuna-Ba. 2001.

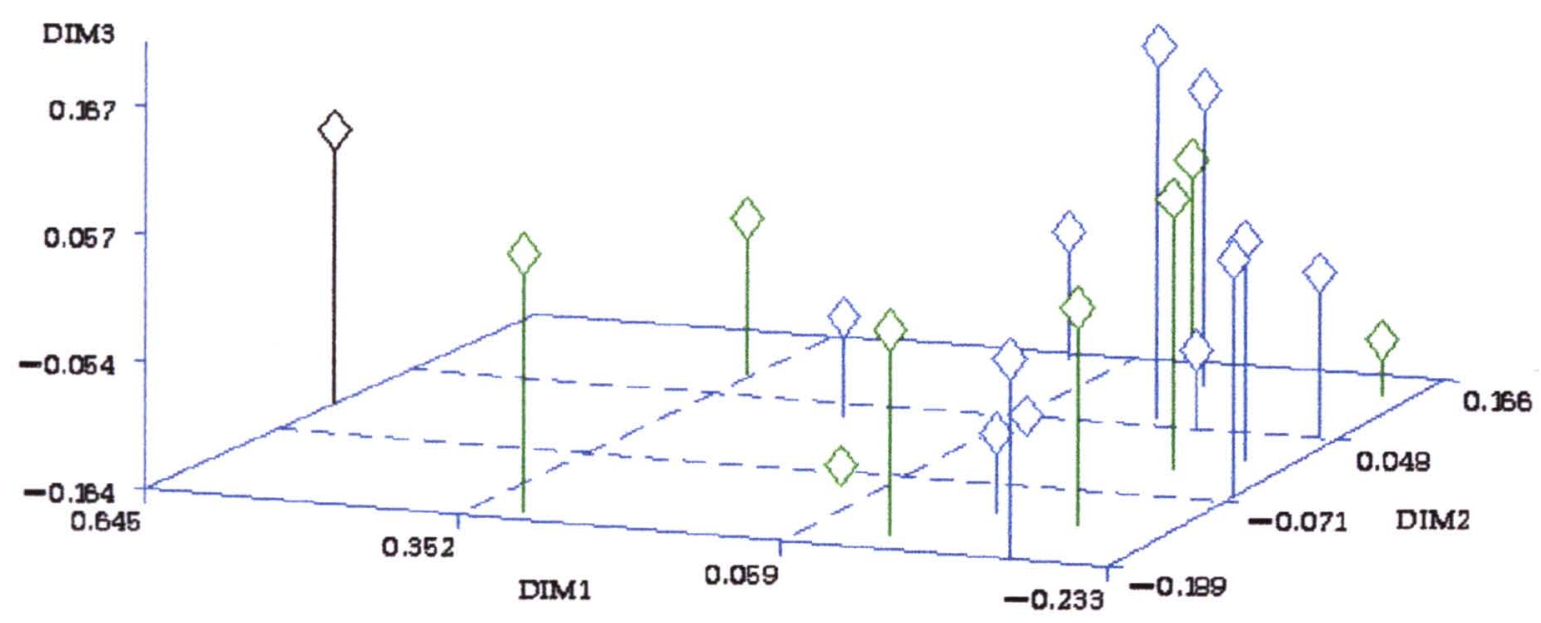

verde: itabuna - azul: outro municipio.

preto: referencia.

coordenadas: PROC MDS - SAS a partir da matriz de distanclas simples excluidos as hospitais B H P Q 


\section{Figura 8}

\section{Dispersão dos hospitais agrupados conforme constituição enquanto campo de ensino - Itabuna-Ba, 2001.}

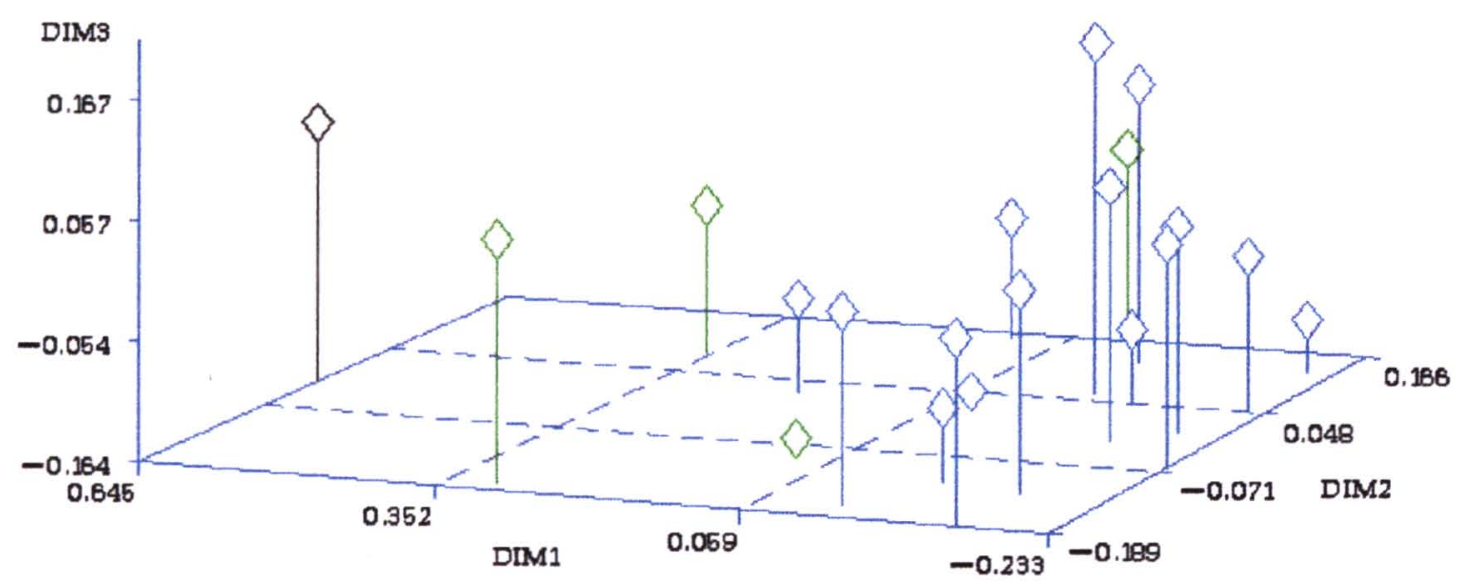

verde: campo de ensino - azul: nao. 
Figura 9

Dispersão dos hospitais agrupados conforme existência de Comissão de Controle de Infecção Hospitalar - Itabuna-Ba,

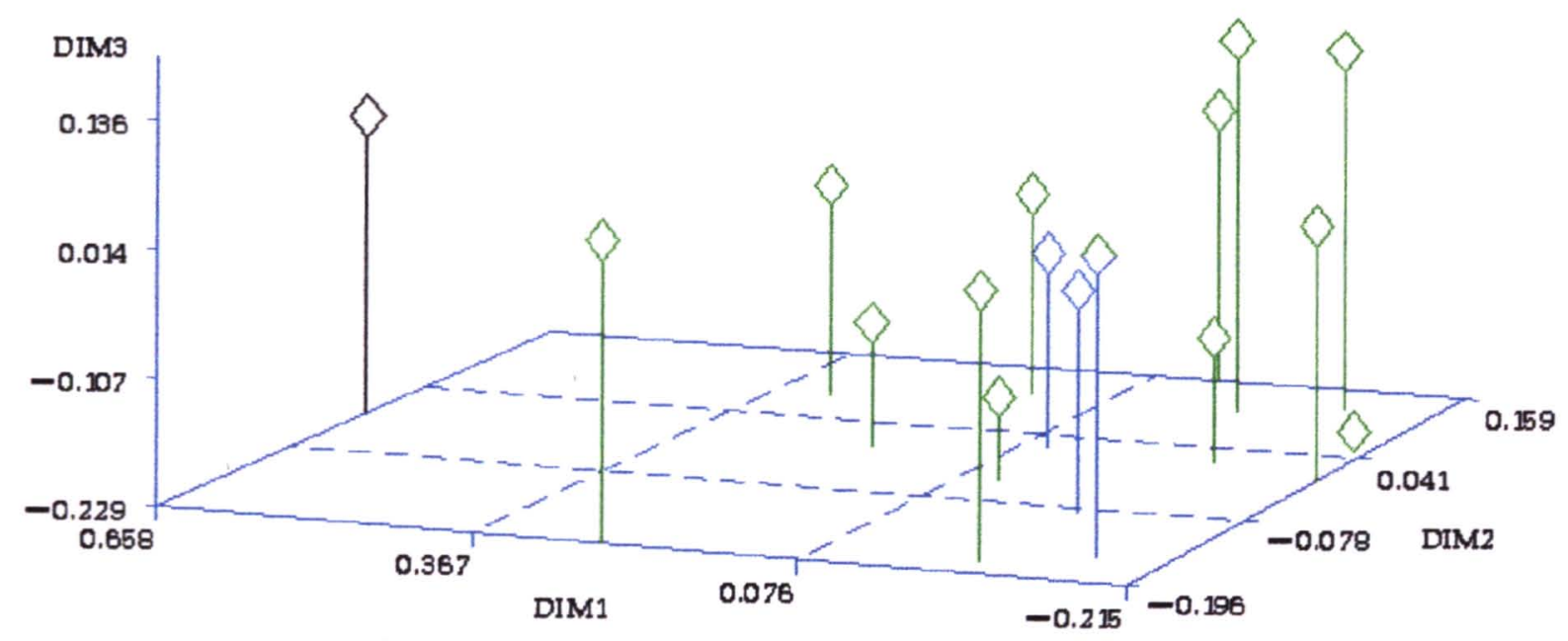

verde: com comissao - azul: sem comissao.

preto: referencia.

ceordenadas: PROC MDS - SAS a partir da matriz de distancias simples. excluidos os hospitais B H P Q R WL

Figura 10

Dispersão dos hospitais agrupados conforme existência de Grupo Executor de Controle de Infecção Hospitalar - Itabuna-Ba, 2001.

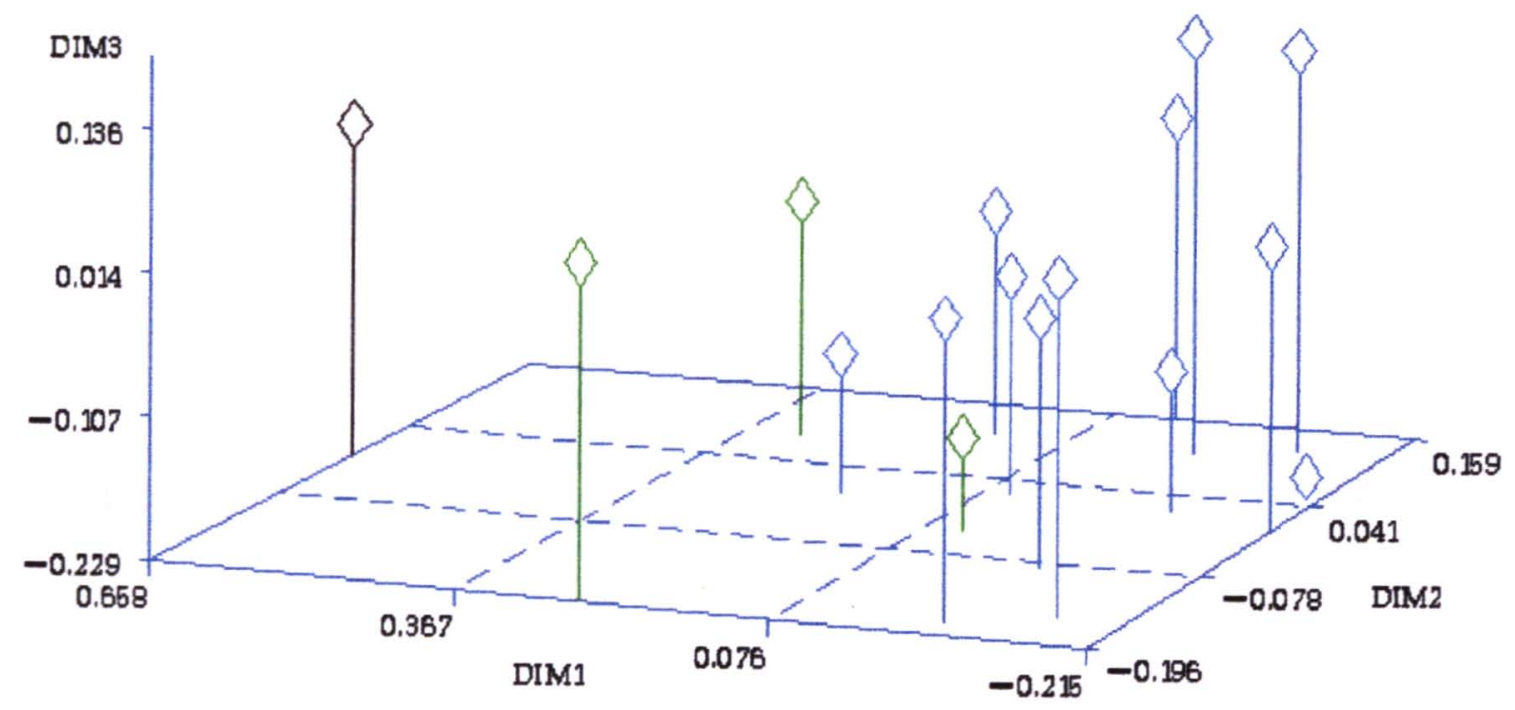

verde: com servico - azul: sem servico.

preto: referencia.

coordenadas: PROC MDS - SAS a partir da matriz de distancias simples, excluidos os hospitais B H P Q R WL 


\section{DISCUSSÃO}

\subsection{Infra-estrutura organizacional dos hospitais, nos aspectos relativos à biossegurança - As comissões de controle de infecções e as comissões internas de prevenção de acidentes}

Sobre a infra-estrutura de biossegurança nos hospitais, inicia-se com a discussão acerca da situação 'regional das Comissões de Controle de Infecção Hospitalar (CCIHs), e das Comissões Internas de Prevenção de Acidentes (CIPAs), posta a importância desses órgãos na conformação de uma adequada estrutura de biossegurança nos hospitais. A primeira por ter sob os seus auspícios a responsabilidade sobre normatizações afetas aos riscos biológicos em hospitais e a segunda por seu papel na defesa dos aspectos atinentes à saúde do trabalhador .

Assim chama-nos à atenção os modestos números de presença dos referidos órgãos nas instituições estudadas. Dos vinte e cinco hospitais investigados somente dezenove $(76,0 \%)$ possuem CCIH e somente três $(12,0 \%)$ possuem CIPA .

Embora não tenhamos encontrado estudos referentes à presença de CIPAs em hospitais, no que diz respeito à presença de $\mathrm{CCIH}$, podemos dizer que os dados mostram-se abaixo do que demonstram estudos desenvolvidos em outras localidades nacionais em que pesem as especificidades regionais. OLIVEIRA(1997), por exemplo, detectou a presença do órgão em $92,0 \%$ das cidades de Campinas e região. GONTIJO JÚNIOR (1991), por seu turno, verificou em Belo Horizonte a existência de CCIH em todas as instituições hospitalares da cidade. PEREIRA E MORIYA (1995), se bem que em estudo adstrito a hospitais universitários, verificaram a existência de $\mathrm{CCIH}$ em $94,5 \%$ das instituições.

Por outro lado quando nos atemos aos nossos dados verificamos maior precariedade da presença dos órgãos nos hospitais públicos, instituições que em tese deveriam servir como agências diferenciadas no que diz respeito ao controle de infecções e também no referente à uma estruturação mínima de cuidados à saúde do trabalhador. 
Vale ressaltar,contudo, que a maioria dos hospitais públicos estudados $(83,3 \%)$ constituise de instituições de pequeno porte, para as quais a Portaria 2.616(BRASIL 1998) faculta a presença de $\mathrm{CCIH}$, embora preveja o estabelecimento de consórcios com serviços de maior porte para o trato das questões relativas ao controle das infecções hospitalares. Esses mesmos consórcios inexistem, entretanto, nas instituições em apreço.

Do ponto de vista da organização das CCIHs existentes, observamos, por outro lado, que a sua maioria restringe a sua composição à três componentes, mais presentes o médico e a enfermeira, e essa última responsabiliza-se por quase todas as atividades relativas à prevenção e controle das IHs. Também os dados mostram- se diferentes de outros estudos. Todavia, devemos levar em conta que a maioria de hospitais aqui estudados trata-se de instituições de pequeno e médio porte, o que pode explicar composições mais modestas dos respectivos órgãos. Somente à título de ilustração PEREIRA E MORIYA (1995) encontraram variação no número de componentes de três a vinte profissionais por $\mathrm{CCIH}$, sendo que a maior freqüência foi da composição com seis à oito pessoas.

Estudos outros que reproduzam realidade mais aproximada à detectada aqui não foram encontrados na literatura, mas é possível que os dados reflitam parte substantiva da realidade nacional, abstraidos os casos dos maiores centros e das especificidades dos hospitais de ensino.

Observamos que as comissões em estudo não dispõem, em sua maioria (quase 90\%), sequer de estatuto, ainda que boa parte delas tenham sido implementada há mais de quatro anos o que desvela a problemática da normatização mínima até sobre o próprio funcionamento dos respectivos órgãos e, consequentemente sobre as ações por eles desenvolvidas.

No tocante às reuniōes das Comissões, importantes mecanismos de trocas de experiências, de difusão de conhecimentos e de tomada de decisões, podemos dizer serem elas consideradas bem pouco freqüentes na realidade analisada. Em seis dos hospitais $(31,6 \%)$, elas ocorrem em periodos que ultrapassam seis meses, o que se 
desveste até de sentido, ainda mais se considerando o corpo reduzido de pessoal que se dedica, pelo menos parcialmente, às atividades e a suposta necessidade de se trocar minimamente idéias sobre os rumos das problemáticas que lhe são afetas, dentre elas certamente as referentes à temática da biossegurança.

Em respeito à experiência dos componentes das CCIHs que, conforme depreendemos, restringem-se praticamente apenas aos enfermeiros, a exceção dos dois hospitais providos de grupos executores de controle de $\mathrm{IH}$, que dispõem de médicos em dedicação parcial, verificamos que uma boa parte dos enfermeiros, sete $(36,8 \%)$, portanto do total dos profissionais em tela, têm experiência em $\mathrm{CCIH}$ de até um ano o que também demostra fragilidade na composição das organizações. Essa realidade é mais contundente nos hospitais públicos, cujo percentual fica em $87,5 \%$.

Ainda que não tenha sido objetivo aprofundarmo-nos em todas as atividades desenvolvidas pelas CCIHs, mas particularmente nas suas caracteristicas de conformação que tomam parte e influenciam nas ações institucionais afetas às medidas de biossegurança, detectamos que as atividades desenvolvidas pelos órgãos mais citadas recaem sobre a vigilância epidemiológica das $\mathrm{IH}$ e, ação subseqüente a essa, elaboração de planilhas dirigidas em particular aos órgãos superiores, no caso em apreço, à própria Sétima Diretoria Regional de Saúde da Bahia. Apenas três enfermeiros $(15,8 \%)$ referiram, como parte de suas atividades à frente da $\mathrm{CCIH}$, a educação continuada de profissionais e uma $(5,3 \%)$, a implementação de isolamentos de pacientes.

Dados que chamam à atenção quando sabemos que se inclui dentre as mais importantes atividades das CCIHs a educação continuada dos profissionais para a minimização dos riscos relativos às infecções hospitalares para os pacientes, e dos próprios riscos ocupacionais aos agentes biológicos, tema deste trabalho. Cabe a observação de que nenhuma das instituições investigadas dispõe de setor ou de profissionais voltados para o treinamento em serviço.

Também a modesta referência à implementação de isolamentos constitui-se emblemática da situação dos hospitais em respeito à prática em questão. Compreendendo-se os enfermeiros atuantes nas CCIHs, pela posição que ocupam, em 
tese, como os mais bem preparados para, conjuntamente com a equipe assistente, implementarem, quando necessário, isolamento de pacientes, pode-se supor que a prática pode vir se dando sem a necessária qualidade.

A problemática da pouca participação das CCIHs nas indicações de isolamento não pode ser vista, contudo, como situação específica de nossa realidade. GONTIJO JÚNIOR (1991), registra, por exemplo, em $11 \%$ de $85 \mathrm{CCIHs}$ de Belo Horizonte, a participação dos referidos órgãos na indicação e supervisão de isolamentos.

No tocante à realização de programas de educação continuada, também GONTIJO JÚNIOR (1991), na mesma pesquisa, chegou a resultados de somente $8 \%$ das instituições confirmam a atividade, percentual inclusive menor que os aqui encontrados.

Especificamente ao preparo dos enfermeiros das $\mathrm{CClHs}$ em assuntos referentes à biossegurança, verifica-se aqui, outrossim, que apenas nove $(47,4 \%)$ realizaram curso/treinamento que contemplaram conteúdos do assunto em pauta.

Podemos dizer que esse é um dado que certamente tem reflexos na presença dos demais itens de estrutura de biossegurança nos hospitais. Conforme será melhor discutido adiante, a presença de $\mathrm{CCIH}$ desvela resultados bastante modestos em respeito à presença dos indicadores aqui utilizados .

Situação que pode ser considerada como digna de nota é a de que além de reduzido, o número de enfermeiros atuantes nas CCIHs estudadas que tiveram acesso a atualizações relativas ao tema, é ainda constituído por uma maioria de profissionais atuantes em hospitais privados e filantrópicos, contrariamente aos próprios hospitais públicos.

Nossos dados contrastam com estudo de OLIVEIRA (1997) que argüindo sobre o treinamento prévio dos profissionais atuantes nos grupos executores de controle de $\mathrm{IH}$, sem, entretanto, tratar especificamente de temas referentes à biossegurança, chegou a resultados, para os hospitais de Campinas e região, que é nos hospitais públicos que se 
registram os melhores resultados percentuais relativos ao preparo dos componentes das CCIHs.

Não encontramos, na literatura, trabalhos que tenham buscado estudar a formação dos

profissionais atuantes nas CCIHs, no tocante especificamente à biossegurança, que confirmem ou refutem os números sob análise. Possivelmente, por se constituir o assunto relativamente recente ou até mesmo porque o tema, em geral, é tratado no conjunto de demais itens relativos à atualização de pessoal para atuar à frente das CCIHs. Porém, os estudiosos são unânimes em confirmar, a importância do preparo prévio e da atualização constante dos seus membros, quando da avaliação dos mesmos órgãos (OLIVEIRA 1997; GONTIJO JÚNIOR 1991; PEREIRA e MORIYA 1995; PRADE et al1995).

Se, de um lado, a situação dos hospitais da região estudada, no que se refere à organização das CCIHs, não se mostra das mais promissoras, não é menos verdade que as Comissões Internas de Prevenção de Acidentes, praticamente inexistentes (estão implementadas em apenas três - 12\% das instituições), também não desfrutem de melhor situação. Conquanto tenhamos nos limitado à questão da existência de uma noção mínima acerca de biossegurança por parte de pelo menos um de seus membros, os resultados mostraram-se pífios.

Assim, os dados conjuntos das CCIHs e das poucas CIPAs, as quais poderiam ter um papel coadjuvante de importância para a implementação e cobrança de uma estrutura apropriada de proteção contra os riscos biológicos, demonstram fragilidades que merecem atenção por parte dos formuladores de políticas intra e extra-institucionais.

\subsection{Presença de normas escritas acerca de biossegurança nos hospitais}

Sobre a presença de normas escritas relacionadas a aspectos da biossegurança, aqui a título de análise inicial circunscritas às precauções universais/padrão, verificamos resultados pouco alentadores nos hospitais estudados, posto que foram detectadas em apenas três (12\%) das instituições visitadas, uma de grande porte, outra de médio e uma 
última de pequeno porte, as duas primeiras representadas por hospitais filantrópicos e a última por entidade pública.

Uma possibilidade de explicação para a quase ausência de normatizações nos hospitais acerca das precauções padrão talvez possa ser dada em parte por constituírem-se boa parte dos hospitais estudados, de pequeno porte( $56 \%$ ). Esses hospitais, de acordo com a literatura, apresentam maiores dificuldades em receber as normas dos órgãos de direito e adaptá-las às suas respectivas realidades. Acerca disso cabe observação de CELENTANO et al. (1987), que concluíram, a partir de avaliação empreendida pelo CDC, em amostra de 444 hospitais americanos, que os hospitais com até 49 leitos( de pequeno porte, portanto) possuiam menor probabilidade de adotar as normas elaboradas pelo respectivo órgão. O próprio autor explica o fato, atribuindo-o, também à menor probabilidade dos funcionários desses hospitais considerarem as recomendações aplicáveis às instituições nas quais desenvolvem suas atividades; à rotatividade de pessoas que se dedicam à $\mathrm{CCIH}$, aliada às características próprias desses mesmos profissionais. Tais características coincidem com os resultados ora apresentados, como menor experiência e baixa freqüência a cursos de aperfeiçoamento.

As reflexões de CELENTANO embora possam ser utilizadas para explicar em alguma medida os resultados aqui apresentados, por si só, não dão conta, entretanto, da sua totalidade, posto que a problemática da inexistência por escrito das precauções universais/padrão não está circunscrita no presente estudo apenas aos pequenos hospitais, mas também a entidades de médio e grande porte, cujos percentuais de presença do quesito ora sob análise foram respectivamente de $11,1 \%$ e 50,0\%, índices bastante abaixo do desejável.

Também não se verificam diferenciações entre os hospitais agrupados de acordo com suas caracteristicas jurídico-financeiras, se pública, privada ou filantrópica para a presença da citada normalização .

Chama à atenção, por outro lado, que os hospitais públicos, mais diretamente ligados aos órgãos formuladores de políticas de prevenção e controle de infecções hospitalares e 
também de medidas de biossegurança, apresentem graves debilidades no que se refere à presença de normalizações.

Pouco mais alentadora é a constatação de que os hospitais que se prestam a atividades de ensino apresentem-se com resultados melhores e com diferenças estatisticamente significativas dos seus congêneres que não se prestam à aludida atividade. De igual modo, percebemos diferenciação nos hospitais segundo a existência de grupo executor de controle de IH o que demonstra que esses órgãos colaboram para uma melhor sistematização das normas afetas à biossegurança, pelo menos na nossa realidade e em respeito ao item aqui abordado.

Não se pode perder de vista, entretanto, que embora distinções entre grupos de hospitais com e sem grupo executor de controle de IH e mesmo entre os que se prestam ao ensino, os resultados mostram-se, no geral, muito pobres.

Observamos que conquanto não se busque comparação de realidades tão diversas, vale a pena citar estudo de HERSEY e MARTIN (1994) que detectaram, em amostra de 34 hospitais americanos, presença de normas escritas para a proteção da equipe para sangue e secreções, em 100,0\% das instituições, o que demonstra o quão atrasados estamos em matéria de presença nos hospitais de sistematização das medidas preventivas mais básicas relativas à biossegurança.

No que tange à presença de normatização por escrito acerca das precauções baseadas na transmissão, podemos afirmar que o quadro é ainda mais precário nas instituições estudadas. Detectamos que apenas dois hospitais (8,0\% das instituições), um de grande e outro de médio porte, o primeiro público e o segundo filantrópico as dispõem.

Note-se que nossos dados acerca da presença de normatizações por escrito para isolamento de pacientes encontrados em somente 8,0\% dos hospitais apresentam-se muito diferentes e aquém dos encontrados por OLIVEIRA (1997) em hospitais do interior paulista, cujo percentual foi de $43,0 \%$ das instituições visitadas, índice esse ainda assim considerado pela autora como modesto. 
Em relação à realidade de outros países pode-se citar HUSKINS et al. (1996) que assinalam que a maioria dos hospitais americanos tem acesso às normas para isolamento de pacientes.

Os autores supracitados, ressaltando adicionalmente a importância da presença das normas de isolamentos nos hospitais referem que mesmo quando essas estão presentes nas instituições, o que em verdade não ocorre, cumpre-se repetir, à contento na realidade aqui estudada conforme explicitam os dados, elas não têm probabilidade de serem efetivamente utilizadas, se não estão disponíveis para a equipe que assiste os pacientes, se a responsabilidade pela determinação da necessidade de precauções não está claramente definida e se a CCIH/Grupo executor de Controle de Infecção não supervisiona e reforça o seu emprego.

Assim, afora o aspecto de se encontrar quantitativo restrito de instituições com normatizações escritas para as precauções ora em pauta, chamou-nos também a atenção, a observação de que, para os próprios enfermeiros entrevistados, que em sua maioria acumulam as funções de coordenadores de enfermagem e de membros mais atuantes das CCIHs, e ainda para os próprios profissionais atuantes exclusivamente nos poucos grupos executores de controle de IH existentes, não parece haver clareza sobre os tipos e as diferentes indicações de precauções aqui sob análise ou, pelo menos, conhecimento da sua nomenclatura atualizada.

Para ilustrar essa observação, tomemos o exemplo de que os enfermeiros, em geral, relacionaram como infecções com indicação de isolamento de contato doenças que vão da hepatite, sem especificar o tipo, ou exemplificar situação, à meningite, à AIDS e à tuberculose. No concernente às doenças para as quais implementam-se, nos hospitais, precauções por gotícula, 68,0\% das entrevistadas não souberam responder à indagação, $20,0 \%$ indicaram a tuberculose, 4,0\% relacionaram a AIDS e o mesmo percentual indicou a herpes zoster e, demonstrativo de grave desconhecimento acerca de doenças transmissiveis, a doença pulmonar obstrutiva crônica. No tocante às precauções aéreas ou por aerossóis, houve, contudo, maior confluência de respostas com correção e as indicações recaíram sobre a tuberculose e o sarampo. 
Em que pese a possibilidade de viés de entendimento dos entrevistados da questão posta, não podemos nos furtar de inferir que a situação constatada pode ser um indicativo da precariedade da própria implementação de isolamentos nos hospitais e conseqüências a elas inerentes, sumariados na imprecisão, custos adicionais e riscos potenciais aos usuários e profissionais.

Por outro lado se percebe nesse contexto o fraco preparo dos enfermeiros para atuarem à frente das CCIHs, no que diz respeito à própria qualificação e também à experiência profissional que, conforme vista, em particular nos hospitais públicos se mostra modesta.

Concordamos com THOLINSON et al. (1993) que consideram de suma importância um programa de treinamento em serviço para os próprios enfermeiros das CCIHs e de enfermeiros experientes no controle de infecção para a adoção de determinadas práticas e padrões pelos demais trabalhadores de saúde dos hospitais.

A importância da existência de enfermeiros com domínio dos conhecimentos acerca das precauções e isolamentos à frente das CCIHs pode ser ilustrada em boa medida pelo estudo de PEREIRA e MORIYA (1995) que afirmam que para metade das instituições por elas estudadas as dificuldades de se fazer cumprir as medidas uniformemente pela equipe assistencial são a resistência na implementação das precauções e a falta de preparo ou desinteresse em implementar as técnicas $(28,39 \%)$ por essa mesma equipe.

Somente à título de ilustração posto que não tratamos diretamente desse assunto citamos CELENTANO et al. (1987) que em estudo também desenvolvido nos Estados Unidos, mostram que as normas relativas a isolamentos haviam, à época, sido completamente lidas pela maioria dos componentes das $\mathrm{CCIHs}$ dos hospitais, independente do porte das instituições.

Não é possivel se afirmar que os enfermeiros de nosso estudo não tenham pelo menos lido as normas mais atuais, mas as dúvidas suscitadas, conforme citado, permite inferir que é bem possivel que esses profissionais, na sua maioria, não teve acesso às bibliografias e normatizações nacionais pertinentes. 
De todo exposto convém citarmos, todavia, que depreendemos das visitas aos serviços, que somam-se ao suposto desconhecimento dos enfermeiros entrevistados acerca das precauções baseadas na transmissão, também deficiências relacionadas às estruturas físicas e materiais dos hospitais. Para ilustrar, cumpre-nos citar que ao argüirmos os enfermeiros acerca das preconizações hospitalares, independentemente da presença das normatizações por escrito, em somente $84 \%$ das instituições ,os enfermeiros referiram como prática nas instituições nas quais exercem o seu ofício, a indicação de quarto privativo ou coorte de pacientes acometidos pelos mesmos microorganismos, no caso das precauções de contato. $\mathrm{O}$ uso de luvas pelos profissionais durante o contato direto com pacientes sob o mesmo tipo de isolamento é reportado como usual pelos enfermeiros responsáveis por $72 \%$ das instituições estudadas. A preconização do uso de aventais para o trato direto com os mesmos pacientes é reportado em $56 \%$ das instituições e a recomendação do uso de equipamentos de uso exclusivo para os pacientes sob o mesmo tipo de isolamento recai em $36 \%$.

Para as precauções com goticulas, a referência à recomendação ao emprego de quarto privativo ou coorte de pacientes aparece em percentual de $68,4 \%$ e o uso de máscaras cirúrgicas pelos profissionais, ao prestar cuidados aos pacientes com infecções transmissíveis pela via ora discutida, é informada como preconizada em $47,3 \%$ das instituições.

Em $76 \%$ dos hospitais isolam-se pacientes com suspeita de tuberculose e as referências às práticas utilizadas nas instituições para o fim específico são as seguintes: manutenção das portas dos quartos fechadas: 50\%; manutenção das janelas abertas:56,2\%, facilitação da iluminação solar dos aposentos :37,5\%; uso de máscaras cirúrgicas pelos pacientes quando em deslocamento no hospital:31,2\% e, por fim, o emprego de máscaras $\mathrm{N} 95$ por parte dos profissionais quando em contato direto com os mesmos pacientes ,inexistente em todas as instituições.

No tocante às normatizações escritas relativas ao atendimento de casos de acidentes de profissionais do hospital com materiais pérfuro-cortantes, percebemos neste presente estudo que um número pouco mais expressivo de hospitais as dispõem $(32,0 \%)$, se 
comparados com as relativas às precauções padrão e baseadas na transmissão, mas ainda assim contingente que pode ser considerado distanciado do ideal. Esse fato chama a atenção, levando-se em conta, primeiro que essas normas constituem-se, como de se esperar, em reproduções daquelas publicadas pelo Ministério da Saúde e, segundo que elas se encontram mais nos hospitais filantrópicos $(83,3 \%)$, do que nos próprios hospitais públicos, havendo, inclusive, diferenças estatísticas significativas para a presença do item nos serviços quando subdivididos por categoria jurídico-financeira. Apenas um hospital público, de pequeno porte $(8,3 \%)$, dispõe das referidas normatizações.

Quanto as instituições públicas, uma explicação plausível para a praticamente inexistência de normatizações relativas a condutas frente a acidentes com pérfurocortantes, talvez seja o fato de que esse agrupamento de hospitais compreendam coincidentemente, em sua maioria, na região, conforme já citado, os pequenos serviços para onde se encaminham os clientes de menor complexidade, fazendo com que preocupações com acidentes de profissionais com objetos pérfuro-cortantes sejam menores. Não devemos perder de vista, todavia, que o único hospital público de grande porte e responsável pelo atendimento de pacientes mais complexos se comparados aos dos pequenos nosocômios, não dispõe das referidas normatizações.

Assim, no que tange os hospitais públicos em geral não podemos deixar de registrar que parece ocorrer alguma lacuna na divulgação das instruções normativas por parte dos responsáveis técnicos pela área em nível governamental, posto que teoricamente todas as instituições devem não apenas tê-las disponíveis mas também aplicá-las quando indicado e serem supervisionados pelo poder público quanto à sua aplicação.

Cabe a observação de que todos os hospitais públicos visitados, a exceção de um, à época, em período de credenciamento pelo SUS, dispõem de centro cirúrgico/obstétrico em atividade e boa parte também de pequenos prontos socorros, unidades que, de acordo com a literatura, pela própria natureza e processo de trabalho expõem mais os profissionais à acidentes, isto sem contar com as próprias unidades de internação que também não podem ser desconsideradas. 
Por seu turno, a situação nos hospitais privados é também pouco animadora. Observemos, adicionalmente, que boa parte dessas instituições é de médio porte. Tal constatação faz supor que nesses serviços sejam desenvolvidos números mais expressivos de procedimentos invasivos e, em conseqüência, maiores possibilidades de acidentes, face ao atendimento de pacientes cuja atenção deve ser, pelo menos em tese, mais complexa se comparada com aquela desenvolvida pelos pequenos hospitais.

Para estabelecermos um paralelo com outros estudos que tratem da presença de normatizações acerca de condutas frente à eventuais acidentes com materiais perfuro cortantes tomamos LACERDA (2000) que buscou saber da existência de providências formais em casos de ocorrência de exposição ocupacional à sangue e outros fluidos orgânicos de pacientes em 88 instituições de uma população de acesso de 1586 hospitais.

A autora detectou que em $11,4 \%$ das instituições referiu-se não se dispor de providências formais frente às exposições, em 26 serviços hospitalares $(21,3 \%)$, as providências recaiam sobre a existência de uma ficha/protocolo de profilaxia; em dezessete $(13,9 \%)$, à notificação ao grupo executor de controle de infecções hospitalares; em treze $(10,6 \%)$ o mesmo registro junto à CIPA/CIAT (Comissão Institucional de Acidente de Trabalho); em nove (7,3\%), à notificação ao SESMT (Serviço Especializado de Segurança e Medicina do Trabalho); em oito (6,5\%), ao acompanhamento de sorologia ; em sete (5.7\%), à ficha de notificação; em dez ( $8,1 \%)$, a campanhas de prevenção e palestras.

Os resultados levaram a autora inferir, ainda que reconhecendo seu entendimento de fue percentagem significativa de hospitais tenha citado a existência de protocolo de rofilaxia e de que a maioria dos hospitais tenha relatado algum tipo de providência nos :asos de exposição ocupacional ao sangue e outras substâncias orgânicas de pacientes, jue essas diluíam-se em formas variadas de gerenciamento, fazendo-a crer que em nuitas dessas instituições prevaleça a informalidade nas ações. Note-se, todavia, que mbora os diferentes enfoques das perguntas possam conduzir à viés e dificultar uma 
análise comparativa, nos parece, ainda assim, que os resultados detectados pela autora mostram-se melhores daqueles aqui verificados.

Ressaltamos, contudo, que no caso deste presente estudo trabalhamos com o universo todo de hospitais de uma dada região e a questão foi ainda, dirigida para um único aspecto, a existência de normatização escrita acerca das rotinas pós exposição à acidente com material pérfuro-cortante. No estudo de LACERDA trabalhou-se com questão aberta e com questionário a ser devolvido pelas instituições hospitalares investigadas. Sabe-se que nesse tipo de pesquisa pode haver uma tendência de que as instituições que se julgam em melhores condições respondam às questões ao passo que as outras nem sempre se disponibilizam a fazê-lo.

Fazemos essa observação com o intuito de aventar a possibilidade de que as normatizações acerca dos cuidados relativos às exposições ocupacionais ao sangue e secreções não se encontram universalmente presentes nas instituições nacionais.

Observamos que a realidade por nós encontrada e mesmo a verificada por LACERDA (2000) distancia-se muito, ainda que não caibam integralmente comparações com realidades tão diversas, daquelas citadas por GRIME et al. (2001) que em estudo londrino, verificaram a presença de protocolos escritos para os casos de exposição acidental de profissionais à sangue e secreções, em $93 \%$ das instituições hospitalares pesquisadas.

Observe-se, por outro lado, que além dos baixos percentuais de existência de normatizações para atendimento de trabalhadores do hospital vítimas de acidentes com materiais pérfuro-cortantes, não detectamos neste presente estudo diferenças estatisticamente significantes para o item quando os hospitais são considerados segundo a presença de $\mathrm{CCIH}$, bem como de grupo executor de controle de $\mathrm{IH}$, muito embora as percentagens indiquem melhores resultados para os providos dos respectivos órgãos.

Concordamos com BELTRAMI et al. (2000), quando defendem que é obrigação dos empregadores no concernente à proteção dos profissionais na eventualidade de 
acidentes que envolvam contato com sangue e fluidos orgânicos de pacientes, dispor de um sistema que inclua a presença de protocolos escritos, de facilidades para a realização de exames e profissionais que possam instituir cuidados pós exposição. E, por fim, com BEEKMANN et al. (2001) que referem que os profissionais da saúde, envolvidos com a prática assistencial em hospitais, encontram-se, com freqüência expressiva, indubitavelmente, em risco de injúrias percutâneas e exposições mucosas à sangue e secreções. A prevenção desses eventos deve ser, em conseqüência, ressalta o autor, incluída como alta prioridade nas instituições, em particular, mas não somente, porque a ocorrência de um único caso de transmissão de patógenos pela via supracitada representa em termos de recursos financeiros custos maiores do que o emprego de todas as medidas preventivas combinadas.

\subsection{Realização de treinamentos para normas de biossegurança}

A inclusão do treinamento/educação continuada dos profissionais, como indicador de um adequado aparato de biossegurança no hospital, embasa - se no princípio de que o cabedal teórico e mesmo prático, construído enquanto ainda nos aparelhos formadores das universidades e dos cursos voltados para a formação em nível médio, supera-se freqüentemente de forma rápida, face à incorporação de novas tecnologias e modificações no cenário assistencial.

No caso específico deste estudo, tratamos como treinamentos necessários, com vistas à proteção para agentes biológicos, de início, aqueles relacionados às precauções padrão. Essas em sua maioria, constituem-se de conhecimentos básicos presentes na formação dos profissionais da saúde envolvidos na prática assistencial em hospital, de longa data, como, por exemplo, o uso de luvas para o contato com sangue e secreções de pacientes. Entretanto, por outro lado esse mesmo conjunto de precauções, incorpora, itens relativamente recentes na prática hospitalar, haja vista a própria recomendação do não re-encape de agulhas, bem como o seu descarte em recipientes apropriados e outros, como o uso de óculos de proteção e protetores de face para procedimentos que envolvam a possibilidade de respingo de sangue. 
Mas tão ou mais importante quanto os novos procedimentos, como a modernização dos EPIs dentre outros, é o reconhecimento da modificação da filosofia que as precauções padrão estão a aportar: a de que os cuidados devam ser aplicados no atendimento de todos os pacientes e a de que o objetivo de se empregar as técnicas recomendadas tem dupla via, ou seja, pretende proteger os pacientes e, ao mesmo tempo, os trabalhadores da saúde.

Por sua vez, as precauções baseadas na transmissão, ainda que sintetizem de alguma forma conhecimentos clássicos acerca de isolamentos em hospitais, trazem, em seu bojo, também modificações no raciocínio acerca das formas de veiculação de doenças e meios de proteção do trabalhador mais recentemente difundidas.

Entendemos, então, o treinamento/educação em serviço como forma de atualização de conhecimentos já apreendidos e re-elaborados na prática assistencial e também de revisita à antigos conteúdos, para o caso dos profissionais atuantes há mais anos, buscando "re-preparar-se" para o atendimento a novas/velhas demandas, no caso aqui em apreço, exemplificada pela própria triagem precoce de pacientes suspeitos de tuberculose, além, naturalmente, da incorporação de novos conhecimentos.

Dessa forma, treinamentos acerca das precauções padrão e baseadas na transmissão e medidas que intentem o reconhecimento de quadros que permitam triar com maior rapidez pacientes com eventual infecção tuberculosa parecem dar conta hoje, minimamente, dos principais conhecimentos relativos às medidas de proteção para agentes biológicos de maior importância, do ponto de vista ocupacional na prática assistencial no hospital.

Não fosse apenas a incorporação/re-elaboração de conteúdos e práticas, a educação em serviço, compreendida na sua acepção mais larga, vislumbra ainda a valorização do trabalhador e a depender do modus operandi através da qual é operada, pode colaborar para a própria discussão do papel do profissional e de seu processo de trabalho. Isto, por si só, já se constitui boa parte do que se almeja com as discussões acerca da biossegurança. Entendemos por fim. que uma equipe bem preparada representa elemento estrutural essencial à implementação das medidas aqui estudadas. 
Assim, não há como negar que os resultados encontrados nesta pesquisa, para esse item parecem distanciados do que se poderia considerar como alvissareiros. Apenas dez $(40 \%)$ das instituições estudadas referiram a realização de algum procedimento de educação em serviço, relativo às precauções universais/padrão e nove (36\%) para as precauções baseadas na transmissão. O treinamento com vistas a triagem precoce de pacientes suspeitos de tuberculose, por outro lado, não foi objeto de educação continuada/treinamento/discussão em nenhum dos hospitais visitados.

Observemos que, a princípio, a questão tratava sobre a existência de treinamentos sistematizados, não se incluindo as referências às orientações no dia- a - dia. Nesse caso, para as precauções padrão, verificamos que apenas três (12\%) instituições realizaram treinamento nos moldes em que foi perguntado e, no tocante à precauções baseadas na transmissão, esse número reduz-se à uma única entidade $(4 \%$ dos hospitais).

Assim, considerando que a educação continuada deve-se fazer de múltiplas formas e que a cada instituição cabe buscar a que mais se adeqüe à sua realidade, e, ainda, levando em conta que as equipes em parte expressiva dos hospitais constituem-se diminutas (conforme pode ser visto na tabela 1) levamos em conta como tendo sido realizado ação relativa à educação em serviço também as referências de orientações assistemáticas. De qualquer sorte, os números continuam, ainda assim, bastante longe do que se poderia chamar de promissores.

Quando analisamos as instituições classificadas por porte, verificamos resultados, para a realização de treinamentos, pouco melhores nos hospitais médios e grandes, ainda que sem distinções significativas estatisticamente. No que se refere à esfera administrativofinanceira, observamos tendência de que os hospitais filantrópicos fiquem melhor posicionados, seguidos das entidades públicas e privadas.

Interessante notarmos que os resultados se fazem mais promissores nas instituições campo de ensino, o que pode ser explicado em parte pela presença, nessas instituições, de maior número de enfermeiros, o que de certa maneira facilita o desenvolvimento de atividades de educação continuada. Também os alunos de graduação em enfermagem 
que utilizam esses mesmos hospitais para o desenvolvimento de suas habilidades, são estimulados, sob a supervisão de um ou outro professor, a desenvolverem atividades extensionistas, as quais incluem a realização de treinamentos para os profissionais aí atuantes.

Em contrapartida, não são distintivas a presença ou não de $\mathrm{CCIH}$, muito embora a existência de grupo executor de controle de infecções hospitalares distinga os hospitais com melhores performances. Estes últimos resultados reforçam o que de alguma forma já se viu quando da discriminação das atividades das CCIHs, que estes órgãos operam pouco no treinamento em serviço.

De certa forma isso é até justificado quando se compreende a modéstia das composições dessas organizações, que em geral limitam-se à presença de uma única enfermeira que dedica-se também a outras atividades administrativas e assistenciais, dificultando-se assim outros empreendimentos.

Por outro lado, principalmente nas pequenas instituições não se justificaria a existência de setores específicos para o ensejo das práticas aqui discutidas e assim não parece haver outra alternativa de que as próprias CCIHs sejam melhor providas de apoio técnico e que sejam elas mesmas que liderem a educação em serviço.

Reforça nossa ótica a observação de PEREIRA \& MORIYA (1995) que estão convencidas de que programas educativos devam constar do cronograma de atividades da $\mathrm{CCIH}$ e que uma de suas responsabilidades seria a de fornecer meios que auxiliassem os seus próprios componentes e toda equipe hospitalar para se promover a atualização dos conhecimentos afetos à área e, consequentemente, garantir desempenho condizente com as inovações técnicas e assistenciais.

Os resultados aqui encontrados, contudo, o da pouca expressão das CCIHs no concernente às distinções dos hospitais para a realização de treinamentos em temas afetos à biossegurança, indicam dissonância com o que vaticinam as autoras. 
Digno de nota é a observação do mesmo estudo de PEREIRA \& MORYIA ( 1995) de que a maioria dos treinamentos/reciclagens citados direciona - se à equipe de enfermagem ( 71 referências - 87,65\%), seguidas dos funcionários da limpeza (67 referências $-82,71 \%)$ e da lavanderia $(49-60,49 \%)$, depois os médicos residentes $(37$ - 45,67\%), estudantes de enfermagem (37 - 45,67\%) e estudantes de medicina ( 30 $37,03 \%$ ). O treinamento do corpo clínico do hospital é referido por dezenove instituições $(23,45 \%)$, pouco abaixo dos funcionários do serviço de manutenção e funcionários do laboratório (22 referências cada-27,16\%).

Também neste presente estudo verificou-se tendência de que os treinamentos se dirijam mais à equipe de enfermagem. Observamos que todos os treinamentos referidos foram direcionados à esse grupo profissional, em particular para os técnicos e auxiliares. Em apenas uma instituição citou-se a realização de reciclagem incluindo conteúdos relativos às precauções padrão para trabalhadores da higienização, as demais categorias não são sequer citadas.

Neste sentido concordamos com LACERDA (2000) que discorrendo sobre a problemática da alta percentagem de profissionais, indistintamente de categorias profissionais que expõem-se ocupacionalmente, refere que é inadmissivel que as ações atinentes à educação continuada, sejam elas executadas através de campanhas, palestras e cursos de conscientização, limitem sua clientela aos trabalhadores da enfermagem.

Todos os profissionais envolvidos na prática assistencial estão, em menor ou maior grau, expostos aos riscos biológicos. Diversos estudos vem sendo empreendidos, por exemplo, para verificar a freqüência de exposição à sangue e secreções de pacientes, com resultados divergentes, ao se apontar as categorias que mais se expõem em termos de número de exposições e sua tipologia. Há variações que vão dos auxiliares de enfermagem, enfermeiros, cirurgiões, anestesistas e pessoal da limpeza, dentre outros.

Os autores são unissonos, todavia, quando enfatizam que as precauções devem ser divulgadas com o objetivo de promover, conjuntamente com outras ações, a redução da exposição dos profissionais aos riscos biológicos e uma das formas de divulgá-las diz respeito ao treinamento em serviço ( LINNEMANN et al. 1991; LAPIDES 1993; 
SOUZA 1999). Por exemplo, nos Estados Unidos, lei federal obriga, os hospitais a instituírem programas de treinamento que tratem da proteção dos trabalhadores contra a exposição a patógenos veiculados pelo sangue .

Objetivando um paralelo da realidade aqui encontrada relativa a treinamentos para práticas de biossegurança pode- se citar BEEKMANN et al. (2001) que em estudo de corte transversal desenvolvido em 153 hospitais de atenção secundária na sua maioria, de pequeno (até cem leitos) e médio porte (maior que cem e menor que 250), para os padrões americanos, localizados fora das regiões metropolitanas dos Estados de IOWA e Virgínia, Estados Unidos, verificaram que todas as instituições realizam pelo menos um treinamento anual para a equipe de enfermagem . Observaram, contudo, que menos da metade das instituições pesquisadas, consideraram como obrigatório o treinamento das equipes médicas.Analisando, por outro lado, as médias de equipes treinadas. por ocupação, verificaram uma taxa de $95 \%$ quando consideram as equipes de enfermagem e limpeza e $27 \%$ para os staffs médicos.

De acordo com os autores, em vários serviços, os médicos não são considerados como empregados das instituições e, em conseqüência, não são treinados pelo hospital. Verificaram também que os treinamentos acerca das precauções padrão são mais freqüentemente oferecidos para os funcionários recém admitidos do que aos demais. Por outro lado. pelo menos $70 \%$ dos hospitais estudados referem oferecer, aos trabalhadores, informações que tratam de riscos ocupacionais advindos de contato com sangue, pelo menos uma vez ao ano, por outras metodologias que não o treinamento formal.

Do exposto depreende-se no contexto americano, como até esperado, ainda que consideremos as limitações apuradas pelo autor, realidade bem mais aproximada do ideal e uma ação bem mais efetiva por parte do Estado no concernente a preocupação com a capacitação de pessoal relativa às normas de auto- proteção dos profissionais atuantes em serviços de saúde.

Apreende-se ainda, em contrapartida, que também em outras realidades o profissional médico é o menos atingido pelos programas de treinamento, seja em medidas de 
controle de infecções hospitalares, seja especificamente relativa às medidas de biossegurança, pelo menos nas aqui consideradas.

Ponto que não pode ser esquecido é a questão da necessidade de treinamentos que tratem da importância do diagnóstico precoce da tuberculose, conquanto o risco de transmissão ocupacional da doença varie consideravelmente entre as muitas instituições, face a prevalência da doença na comunidade, o tipo de clientela atendida pelas diferentes instituições, bem como o número de doentes de tuberculose eventualmente atendidos anualmente. Nesse sentido os resultados da presente pesquisa mostram situação preocupante, uma vez que não conseguimos detectar, em nenhuma instituição, qualquer iniciativa de atualização profissional relativa ao assunto.

Observamos, contudo, que autores nacionais e estrangeiros quando discutem a reemergência da tuberculose como um grave problema de saúde pública são unânimes em afirmar que corroboram para o risco de exposição de profissionais da saúde à infecção, o atraso no diagnóstico da doença em pacientes e a rápida instituição da terapia, resultantes indubitavelmente da falta de atualização profissional acerca do tema.

Para ilustrar, citamos MENZIES et al. (1995) que fazem referência a quatro coortes retrospectivos relativos ao assunto. Tais autores verificaram atraso médio de seis dias no diagnóstico da doença, na metade dos pacientes, o que resultou na exposição de 27 a 44 trabalhadores para cada um dos respectivos usuários, atrasos esses atribuídos em boa parte ao desconhecimento dos médicos sobre a doença.

Também ilustra a problemática da falta de treinamento de pessoal concernente ao atendimento de pacientes com suspeita de tuberculose, trabalho de WHITE et al. (1997) que verificaram que em $25 \%$ dos casos, o isolamento é implementado para pacientes com quadros incompatíveis com o preconizado e em $66 \%$ dos casos compatíveis, esse é implementado com atraso ou nem mesmo empregado. Diante do encontrado, os autores chamam à atenção para a necessidade de medidas que se referem ao aprimoramento dos conhecimentos das equipes hospitalares acerca da tuberculose como forma de reduzir a contaminação dos trabalhadores de saúde. 
Para ilustrar a gravidade de não estarmos em nossas instituições nos ocupando com treinamentos afetos à triagem precoce de pacientes com tuberculose, afim de reduzirmos os riscos de disseminação intra hospitalar da infecção, cumpre-nos citar MESSMER et al. (1998). As pesquisadoras observaram após o desenvolvimento de estudo casocontrole que após a introdução de treinamento em serviço para enfermeiros em dado hospital o número de casos suspeitos para os quais foram instituídos isolamentos, elevou-se em 50\%, com redução das possibilidades de disseminação da doença nas instituições hospitalares nas quais atuam.

Em suma, abstraído o consenso de que cada instituição deva conhecer e direcionar suas ações de capacitação para as problemáticas que mais a afetam, não seria redundante ressaltar, mais uma vez, a relevância de que os hospitais se voltassem para a importância das práticas que não obstante essenciais para o próprio atendimento com qualidade e segurança da sua clientela, conferem ainda proteção da saúde do seu quadro de colaboradores.

Neste sentido MARQUES (2000), cita que as medidas de precauções e isolamentos necessitam da ampla cooperação da equipe hospitalar. Os obstáculos para sua implementação são inúmeros, alerta a autora: falta de espaço físico, de materiais, de proteção, de conhecimento técnico. Segundo a autora, dos itens, o mais importante, todavia, ainda que consideradas as dificuldades, constitui-se na conscientização plena dos envolvidos.

\subsection{Realização de registros concernentes à biossegurança}

Observamos no presente estudo que apenas sete $(28,0 \%)$, dos vinte e cinco hospitais estudados, dispõem de mecanismos de registros de acidentes de profissionais com materiais pérfuro-cortantes. Conforme visto, resultados pouco melhores são encontrados nos hospitais de grande e médio porte, embora cumpra-nos registrar que ainda assim, a rotina é pouco difundida dentre as instituições, independente de tamanho em termos de número de leitos. 
Explicação dos próprios enfermeiros responsáveis pelas instituições para a não existência de registros dos acidentes em pauta, em particular nas instituições pequenas, é a sua ocorrência diminuta, o que não justificaria dispêndio de tempo e esforços para a prática ora analisada. Também digno de nota é que essa mesma razão é apresentada pelas instituições de médio e mesmo pelas de grande porte, onde obteve-se a informação de que o número de acidentes não parece ser, na ótica dos entrevistados, objeto de preocupações.

Tais observações embora fundamentadas na prática diária e certamente com correção em alguns dos hospitais, podem levar a crer que não se está levando em conta, com a devida importância, a reconhecida problemática da sub-notificação de acidentes da natureza aqui pesquisada, objeto de diversos estudos nacionais e internacionais (SOUZA 2001; TANDBERG et al. 1991; RABAUD et al. 2000; RODRIGUEZ et al. 1999; BREVIDELLI 1997). Sub notificação essa que nos hospitais de pequeno e também de médio porte podem ocorrer até pela errônea crença de que, nessas instituições, o fato de os pacientes serem supostamente de menor complexidade, constituem-se em menores riscos para a veiculação de agentes infecciosos de importância ocupacional.

A suposição supra citada respalda-se, de alguma forma, em pesquisa de MAC COY et al. (2001) que analisando os resultados de amplo estudo sobre o acompanhamento da aderência às precauções padrão em hospitais nos estados de IOWA e Virgínia, nos Estados Unidos, observaram que os líderes dos serviços de menores portes acabavam promovendo, em suas instituições, um falso senso de segurança nos trabalhadores, em vista da concepção de baixa complexidade dos pacientes atendidos.

Frente ao que observaram, os autores ressaltam que as equipes atuantes em hospitais de menor porte e, em especial, seus administradores, devem ser lembrados da importância da aderência às medidas preconizadas e, ainda, que as exposições e acidentes podem ocorrer em qualquer instituição, independente de tamanho ou nivel de complexidade do seu atendimento. 
Observamos, por outro lado, neste presente estudo, que em todas as instituições que mantém registros de acidentes com materiais pérfuro-cortantes, esses são realizados somente nos períodos matutino e vespertino, de segunda a sexta-feira, quando estão presentes as enfermeiras dos grupos executores de controle de $\mathrm{IH}$, nos hospitais que os dispõem, ou a enfermeira/coordenadora que responde pela $\mathrm{CCIH}$, o que certamente corrobora para a subnotificação e ainda distorções na percepção de demanda por registro dos eventuais casos ocorridos no período noturno e nos finais de semana.

De igual modo também o fato de que nem todas as instituições, conforme já discutido, realizam treinamento em serviço, relacionado a temas de biossegurança, pode colaborar para o desconhecimento dos profissionais acerca da importância de notificar os acidentes, mesmo naquelas instituições cujas administrações estão preocupadas em registrá-los.

Convém destacarmos que em nossa pesquisa, apenas instituições que dispõem de $\mathrm{CCIH}$ e/ou grupo executor de Controle de IH ocupam-se dos referidos registros. Isso permitenos inferir que é necessário haver um aparelhamento estrutural mínimo para que determinadas práticas sejam implementadas, o que de alguma maneira justifica a inexistência dos referidos registros nos serviços hospitalares que não dispõem sequer de $\mathrm{CCIH}$ formalmente investida, ainda que, pelo menos teoricamente, a questão da anotação e acompanhamento de acidentes deva constituir-se em atribuição específica dos órgãos responsáveis pela saúde dos trabalhadores.

Por outro lado, é praticamente senso comum entre os pesquisadores nacionais e internacionais, que os registros institucionais são necessários ao conhecimento da real ocorrência dos eventos, de forma a prover meios para um trabalho mais sistematizado nos próprios hospitais, incluindo-se uma melhor definição epidemiológica de contato com sangue e secreções, bem como da adoção de medidas preventivas e análise de sua eficácia (BELTRAMI et al. 2000)

HENDERSON (2001), por exemplo, enfatiza que em uma era na qual a palavra de ordem é melhorar a qualidade dos serviços de saúde, entender, inclusive 
numericamente, as exposições ocupacionais dos profissionais atuantes nos serviços hospitalares constitui-se num grande desafio.

De igual modo ao modesto número de hospitais que ocupam-se de registar as ocorrências de acidentes de profissionais com materiais pérfuro-cortantes (28\%), o registro de cobertura vacinal para hepatite $B$ dos trabalhadores atuantes nas instituições também não se constitui em prática corrente nos hospitais estudados. Apenas cinco deles $(20 \%)$ referem dispor de registro de profissionais que foram vacinados. Não se detecta, por outro lado, quanto a esse acompanhamento, diferenças estatisticamente significativas dentre os grupos de instituições, quando subdivididos por porte ou por entidade mantenedora. Chama a atenção que nenhuma das instituições filantrópicas, que em outros itens apresentaram resultados pouco melhores que os demais, procedem ao controle da situação vacinal dos profissionais nelas atuantes.

Também não verificamos diferenças para esta mesma conduta entre os hospitais com e sem $\mathrm{CCIH}$ e mesmo entre os que dispõem ou não de grupo executor de Controle de $\mathrm{IH}$, o que nos parece demonstrar fraca atuação desses órgãos no assunto aqui abordado.

É possível que a baixa preocupação das instituições hospitalares, através de seus representantes, com o registro de cobertura vacinal relacione-se com a dinâmica de vacinação dos profissionais da saúde no Brasil. Observamos que, em nosso País, o Ministério da Saúde disponibiliza gratuitamente as vacinas para a hepatite $\mathrm{B}$ e o gerenciamento dos referidos imunobiológicos fica a cargo das instâncias das secretarias municipais de saúde, as quais são demandadas, para a vacinação dos profissionais, pelos respectivos hospitais. Cumpre às respectivas secretarias registrar o quantitativo de doses utilizadas para proceder à reposição de seu estoque. Não cabe aos órgãos, contudo, o controle da situação vacinal dos empregados de cada hospital.

Desse fluxo, depreendemos que caberia aos respectivos serviços hospitalares no caso de se interessarem pela situação vacinal de seus colaboradores, proceder ao registro dos profissionais que foram vacinados, bem como o respectivo número de doses recebidas. Supõe-se assim que os hospitais que não assumem para si o registro de cobertura da vacina deixa somente a cargo dos profissionais neles atuantes a responsabilidade por sua 
imunização ou pelo menos confiam na cobertura conferida pelas ações do poder público, o que de certa forma constitui-se num risco haja vista outras atribuições dos órgãos responsáveis pela vacinação para a hepatite $\mathrm{B}$.

Permitimo-nos contudo referir que a existência de registros de cobertura vacinal nos hospitais constitui-se num indicativo da qualidade estrutural das instituições no que se refere à proteção da saúde de seus trabalhadores. Primeiro, pela importância da proteção conferida pela vacina e, segundo, pela responsabilidade da instituição concernente a ocorrência de acidentes com materiais biológicos contaminados na ausência de proteção vacinal, a qual é custeada pelo próprio Estado.

Assim, quando analisamos conjuntamente as informações do modesto número de hospitais que registram a cobertura vacinal de seus colaboradores e os reduzidos números de treinamentos em serviço nas instituições estudadas, em particular os concernentes às precauções padrão, muito embora não tenhamos abordado, no caso dos treinamentos, o caso especifico de esclarecimentos sobre a importância da vacina, interrogamos, ainda que em alguma medida nos afastando do escopo deste estudo, se de fato os trabalhadores atuantes nos hospitais campos da pesquisa vem sendo adequadamente vacinados. Isso porque, se os profissionais não estão suficientemente esclarecidos, nem tampouco as instituições providenciam um controle da situação vacinal, permite-se uma ambiência para que a prática ocorra de forma assistemática e, consequentemente, possibilita a situação de que nem todos sejam vacinados ou pelo menos de que nem todos recebam todas as doses necessárias.

Pudemos observar, por outro lado, que nos hospitais nos quais se refere proceder ao registro de cobertura vacinal, esse acompanhamento restringe-se em praticamente, conforme nos informaram os respondentes, ao acompanhamento da situação do pessoal da enfermagem. Parece problemática a situação de categorias outras que realizam atividades que também podem colocá-las em risco. Exemplo disso são os trabalhadores que realizam atividades de higienização hospitalar e que podem estar desassistidos até porque pelas características próprias da sua inserção institucional podem, por lapsos de controle, não serem incluídos numa eventual programação de vacinação. É problemática 
até mesmo a categoria médica, especialmente a dos cirurgiões, em freqüente contato com sangue, que não obstante possivelmente com maior acesso aos meios de informação, pelo menos quando comparados aos demais profissionais aqui citados, podem não estar tendo a atenção merecida por parte das administrações institucionais no que se refere à sua imunização.

Pesquisa de RAMSEY e GLEEN (1996), ilustram, em certa medida, a validade da suposição supramencionada quando verificam, em estudo comparativo conduzido nos Estados Unidos, em 1991 e 1993, elevação na aderência por parte de profissionais da saúde, à vacinação para a hepatite $\mathrm{B}$, disponivel desde 1982 para uso em hospitais, de $61,4 \%$ para $82,5 \%$, após a implementação nos hospitais das precauções universais/ padrão, da obrigatoriedade dos serviços oferecerem a vacina gratuitamente a partir de 1991, e ao estabelecimento de melhores medidas de controle da situação vacinal dos profissionais.

Citamos também THOMPSON e NORRIS (1999), que em estudo desenvolvido em hospitais australianos verificaram em 69 instituições amostradas no Estado de Victória, que somente $27(39 \%)$ dos serviços procediam análise da cobertura vacinal para a hepatite $B$ de seus profissionais. Observe-se que os dados encontrados pelos pesquisadores citados apresentam-se mais promissores que os aqui detectados $(20 \%$ de existência de registro de cobertura vacinal) mas ainda assim os autores concluem pela necessidade de melhorias no sistema de informações hospitalares que permita melhor seguimento sobre a situação de vacinação dos trabalhadores. Observaram ainda que os próprios dirigentes hospitalares listaram, como barreiras para a implementação à contento de um bom nível de vacinação contra a hepatite $B$, dentre outros, a inexistência de um sistema de registro confiável.

No que concerne a mapas de riscos ambientais para a prevenção de acidentes de trabalho, não foram encontrados no estudo aqui apresentado, em nenhuma das instituições visitadas, mesmo nas de grande porte e nas que dispõem de CIPA.

Malgrado os resultados surpreendam pela constatação de suposta despreocupação nos hospitais de sinalizar, através de recursos gráficos, os locais, situações e fatores que 
podem gerar riscos aqui, no caso específico, aos agentes biológicos nos parece compreensível, posto que se trata a elaboração de mapas de risco, de assunto relativamente recente pelo menos para as instituições de saúde.

Também não é profícua a literatura que trata do tema, indicando que possivelmente, a obrigatoriedade legal da execução de mapas de risco não tem despertado maiores discussões até mesmo nos meios relacionados às infecções hospitalares e às próprias CIPAs.

De qualquer forma, parece de relevância na análise da qualidade dos serviços de saúde, que se leve em conta a elaboração de mapas de riscos institucionais. Isso, posto que, ao pressupor ampla discussão com os trabalhadores, a sua confecção remete minimamente para o despertar do interesse aos riscos que o trabalho em saúde pode conferir, bem como para mecanismos que possam minimizá-los. Os mapas constituem-se ainda em alertas visuais que podem colaborar com a aderência às práticas preventivas como também para o próprio aperfeiçoamento do sistema de registros de acidentes ocupacionais envolvendo materiais biológicos.

A elaboração de mapas de risco pode se prestar ainda, enquanto instrumento dos trabalhadores para apontar e cobrar dos empregadores necessidades de implementação de medidas corretivas relacionadas ao ambiente e ao processo de trabalho.

Pode acontecer, todavia, de o recurso aqui discutido reduzir-se a mais um cartaz, dentre os muitos já existentes nas várias instituições de saúde, com o risco de ser utilizado, contra o trabalhador e não a seu favor, se não acompanhado de adequada educação continuada, disponibilidade de equipamentos de proteção individual e das citadas modificações no processo de trabalho como relação adequada corpo de enfermagem e leitos, médicos e número de atendimentos, cargas horárias e remunerações minimamente condizentes, infra-estrutura física compatível, adequados programas de vacinação e acompanhamento de profissionais acidentados, dentre outros fatores.

De acordo a Portaria do Ministério do Trabalho n. ${ }^{\circ}$ 05, de 17 de agosto de 1992 e atualizada pela Portaria 24, de 1994, o mapa de riscos deve ser elaborado pela CIPA, 
ouvidos os trabalhadores envolvidos no processo produtivo e com a orientação do Serviço Especializado em Segurança e Medicina do Trabalho - SESMET, quando houver. Considera-se indispensável, portanto, a participação de pessoas expostas aos riscos cotidianamente (BRASIL 1994a). A obrigatoriedade do mapeamento se encontra em pleno vigor e sua não elaboração, bem como afixação, nos locais de trabalho, pode implicar em multas à instituição empregadora, de acordo com a legislação. Deve ainda ser atualizado anualmente, com a renovação dos membros participantes da CIPA.

De acordo com LIMA E OLIVEIRA (1987), um dos determinantes do quadro atual de saúde do trabalhador no Brasil que é considerado precário, recai, dentre outros elementos de ordem estrutural, sobre a desinformação dos próprios trabalhadores a respeito dos riscos existentes nos ambientes de trabalho, capazes de se constituírem em agravos à saúde. Para os autores, é consenso entre os estudiosos que, ao baixo nível de informação, alia-se a sua conseqüente fragilidade organizacional, o que os impede de desempenhar, à contento, o papel que lhes cabe na promoção e proteção de sua saúde.

Por sua vez, a CIPA (Comissão Interna de Prevenção de Acidentes), quando existente, embora se constitua em oportunidade importante para o trabalhador se informar à respeito dos riscos presentes, capazes de ensejar a ocorrência de agravos à sua saúde, de um modo geral, por diversas razões, não vem cumprindo o seu papel na melhoria dos níveis de saúde nos ambientes de trabalho, ressaltam os autores. Em vista disso para colaborar com a modificação desse quadro aqueles pesquisadores propõem que os treinamentos dos representantes dos empregados, nas CIPAS, devam ser trabalhados com metodologias participativas e com elaboração de mapas de riscos incluídos na programação.

\subsection{Atenção médica admissional e rotinas de imunização profisssional}

A realização de exames médicos dos trabalhadores engajados nas atividades hospitalares não se constitui em rotina obrigatória na maioria das instituições visitadas. Ainda que tenhamos nos restringido somente à questão do exame admissional, observamos que apenas sete $(28 \%)$ hospitais confirmam a prática. Verificamos também 
que os serviços não se distinguem estatisticamente, quando agrupados pelas várias características aqui utilizadas, mesmo quanto ao porte, nem tampouco por categoria administrativo-financeira, muito embora chame a atenção que em apenas um dos doze hospitais públicos, confirme-se a exigência em pauta.

Entretanto como defende SIQUÉRIA (2001), nas atividades hospitalares assistenciais e laboratoriais, onde a exposição a agentes biológicos mostra-se constante, é imprescindivel a realização de minucioso exame admissional para detectar fatores de imunodeficiência e susceptibilidade aos agentes biológicos prevalentes. Assim, os dados encontrados, aliados à observação do autor, remete à reflexão do quão pouco assistidos encontram-se os trabalhadores dos hospitais sob análise e ainda à inferência dos possiveis riscos a que se submetem os profissionais e também as próprias organizações hospitalares quando não têm os devidos cuidados com a saúde de seus colaboradores.

Observamos que, adicionalmente ao modesto número de instituições que tem como prática a exigência de exame médico para a admissão de novos empregados, em nenhum dos hospitais que exigem o cumprimento do protocolo, que normalmente é realizado por médico do trabalho credenciado, se soube afirmar se o histórico vacinal faz parte do exame. Depreendemos daí que o exame circunscreve-se mais a uma rotina com fins de comprovar se o pleiteante ao cargo está apto ou não ao trabalho, do que propriamente a um elemento coadjuvante de importância às práticas preventivas relacionadas ao exercício laboral em meio a riscos.

Verificamos, ainda, muito embora esta análise não se albergue ao escopo deste trabalho, descumprimento pela maior parte das instituições, daquilo que institui a NR n. ${ }^{\circ}$, da 3.214 de 1978 (BRASIL 1978), atualizada pela portaria 25, de 1994. Essa portaria estabelece a obrigatoriedade de elaboração e implementação de Programa de Controle Médico de Saúde Ocupacional - PCMSO, por parte de todos os empregadores e instituições que admitam trabalhadores como empregados regidos pela Consolidação da Leis do Trabalho - CLT. Essa exigência é uma realidade, a exceção de um hospital, em todos os serviços aqui pesquisados. O PCMSO tem o objetivo de promover a preservação da saúde do conjunto de seus trabalhadores, deve ter caráter de prevenção, 
rastreamento e diagnóstico precoce dos agravos à saúde relacionados ao trabalho, inclusive de natureza subclínica, além da constatação da existência de casos de doenças profissionais ou danos irreversíveis à saúde. Planejado e implementado com base nos riscos à saúde o PCMSO deve incluir, entre outros, a realização obrigatória dos exames médico admissionais e periódicos.

De acordo também com a mesma norma, o documento supra mencionado tem que discriminar o número e a natureza dos exames médicos, incluindo avaliações clínicas e exames complementares, bem como estatísticas de resultados considerados anormais.

Demonstrativo do quanto as instituições aqui pesquisadas encontram-se aquém do ideal no que concerne à realização de exames médicos aqui em tela, podemos referir que além da importância do cumprimento da legislação vigente a problemática dos riscos ocupacionais, em particular daqueles relacionados aos agentes biológicos nos hospitais, tem alentado discussões inclusive sobre a necessidade do próprio aperfeiçoamento dessas mesmas normas legais afetas às medidas de proteção à saúde especificamente dos trabalhadores atuantes em hospitais (REVISTA PROTEÇÃO 2002).

O Conselho Regional de Medicina de São Paulo (CREMESP) editou, por exemplo, a Resolução 90/2000, que trata, com maior especificidade, dos riscos biológicos e da obrigatoriedade das instituições proverem meios de franco acesso dos profissionais médicos que nelas exercem suas atividades, a equipamentos de proteção adequados, a imunização contra agentes biológicos, tais como os da hepatite $\mathrm{B}$, gripe e para demais doenças evitáveis por vacinação e, em casos de acidentes do tipo pérfuro-cortante com material potencialmente contaminado, acesso às medidas de quimioprofilaxia. $\mathrm{Na}$ aludida resolução, que se circunscreve à prática médica do Estado de São Paulo, os estabelecimentos ou serviços de saúde, públicos e privados, deverão providenciar a realização de exame médico periódico adequado para cada risco ocupacional específico, com o objetivo de prevenir ou diagnosticar precocemente agravos à saúde dos médicos atuantes nas respectivas instituições e, adicionalmente, que os estabelecimentos, por meio de seus responsáveis são obrigados a informar aos profissionais, os riscos ocupacionais existentes nas suas atividades, os resultados dos exames aos quais foram 
submetidos, bem como aqueles relativos às avaliações ambientais nos locais de trabalho (SÃO PAULO 2000).

Cabe, contudo, a observação de que certamente as discussões e conseqüentes legislações pertinentes busquem um ideal que nem sempre é atingido num curso rápido no tempo. De qualquer forma há um mínimo necessário ao qual as instituições não podem se furtar de cumprir, dentre os quais, nos parece, deve se afigurar o exame médico admissional.

Editorial da revista Infection Control And Hospital Epidemiology de 2001, assinado por HENDERSON (2001), ilustra como contraponto que mesmo em paises considerados mais desenvolvidos o cenário da atenção ao trabalhador de saúde atuante sob risco biológico não é dos mais promissores quando, em alusão à uma pesquisa americana, cita que um a cada oito hospitais estudados não oferece acompanhamento médico contínuo dos trabalhadores hospitalares submetidos a riscos biológicos.

Em nosso estudo, sobre a existência de rotina de imunização dos profissionais contra a hepatite B , verificamos que somente nove (36\%) das instituições referem tê-la. Porém não ocorrem distinções significativas para o item, quando os hospitais são subdivididos por diversas características empregadas para fins da pesquisa, nem mesmo por porte ou esfera administrativo-financeira, nem tampouco segundo a existência de $\mathrm{CCIH}$, muito embora tenhamos observado que os hospitais filantrópicos e privados referiram-se mais afirmativamente à prática do que os próprios hospitais públicos.

Diferenças significativas são, contudo, detectadas quando os hospitais são classificados em gerais e especializados, com melhores resultados para os últimos, de acordo com a sua constituição enquanto campo de ensino e existência de grupo executor de controle de $\mathrm{IH}$, cujos resultados mostram-se mais promissores para as instituições providas dos respectivos órgãos.

Observamos que no primeiro caso, os hospitais especializados aqui estudados constituem-se todos voltados para a atenção à mulher, em particular no seu ciclo gravidico puerperal e à criança. Tal contexto faz com que os profissionais atuantes nas 
instituições sejam naturalmente mais afeitos ao tema vacina, pelo menos as concernentes às imunizações dos próprios usuários. Assim pode-se supor que a lida com o assunto influencie, de algum modo, os responsáveis pela condução das ações hospitalares ao que toca ao controle de infecções com a preocupação também relacionada à vacinação dos profissionais. Mister ressaltar que duas das três instituições especializadas são utilizadas como campo de ensino prático.Esse fato pode explicar, pelo menos em parte, os melhores resultados auferidos também por este último agrupamento de hospitais.

Relativo à presença de grupo executor de controle de infecção hospitalar nas instituições, já se espera naturalmente resultados menos modestos do que naquelas desprovidas da respectiva organização, posto que presume-se que, em se tendo profissionais atuantes exclusivamente com o controle de infecções, as rotinas atinentes à proteção dos trabalhadores aos riscos biológicos se façam mais presentes.

Cabe a observação que levamos em conta como dispondo de uma rotina de imunização, a manutenção de uma regularidade na demanda e acompanhamento por parte das instituições da vacinação dos profissionais nelas atuantes. Esse entendimento se deu por duas razões. Primeiro, por existir norma do Ministério da Saúde em respeito ao assunto. Norma essa que se refere às doses necessárias e seus intervalos e, segundo, pelo fato de caber às secretarias municipais de saúde a disponibilização gratuita dos imunobiológicos para os serviços.

Cumpre-nos citar que, além dos nove hospitais nos quais referiu-se um acompanhamento mais de perto da vacinação dos seus profissionais, mais seis instituições, quatro públicas (três de pequeno porte e uma de médio porte) e duas instituições privadas, pequenas, referiram que também os profissionais nelas engajados receberam vacina contra hepatite $B$ em campanhas realizadas pelas secretarias municipais, ainda que sem a participação ativa dos próprios empregadores. O percentual de instituições hospitalares cobertas de alguma maneira pela vacinação passa, então, para a região, consideradas também as informações destes últimos hospitais, a $60 \%$, ou 
seja, quinze instituições de um universo de vinte e cinco. Nas demais entidades, não se soube informar se os profissionais nelas atuantes foram ou não vacinados.

Depreende-se assim, grosso modo, que a questão não se circunscreve, no caso específico dos hospitais aqui estudados, tanto no acesso dos profissionais à vacina propriamente, posto que conforme já citado esta é oferecida de forma gratuita pelo poder público, mas numa assistematização de oferta e acompanhamento, pelo menos no que concerne às instituições enquanto empregadoras, o que pode remeter à baixa cobertura em áreas de risco, desorganização e custos adicionais ao Estado.

Nossa preocupação com os modestos números aqui encontrados acerca de rotina de vacinação contra hepatite $B$ nos hospitais estudados, tem como base algumas publicações dentre as quais podemos citar LEE et al.(1997) que em estudo desenvolvido na Flórida - Estados Unidos, com 255 profissionais atuantes em unidades de emergência, verificaram que $78 \%$ dos profissionais haviam sido completamente imunizados para hepatite $B$ e dentre as razões mais referidas pelos não vacinados para não terem recebido a vacina figurava problemas com as escalas de vacinação $(23 \%)$ e a falta de tempo (20\%), embora outros motivos importantes tenham sido também elencados como por exemplo o medo de contrair a doença com o próprio imunobiológico $(26 \%)$.

Na mesma direção de nossa preocupação com a assistematização no controle vacinal por parte dos empregadores hospitalares podemos referir também STROFFOLINI et al. (1998), que em estudo desenvolvido na Itália, no qual compara a cobertura vacinal contra a hepatite $B$ entre profissionais atuantes em hospitais das cidades de Nápolis, Ferrara e Roma, verificaram que a razão mais referida pelos profissionais não vacinados para não terem se submetido à imunização recaía sobre falhas numa oferta mais ativa da vacina nas instituições.

Também ilustra a problemática da falta de maior sistematização na imunização de profissionais atuantes em hospital contra a hepatite $B$, trabalho nacional de MIRANDA et al. (1993) desenvolvido em hospital do Estado de Santa Catarina, no qual se observou que de 123 profissionais atuantes na instituição, amostrados e entrevistados, 
apenas quatorze $(11,38 \%)$ completaram o número de doses de vacinas contra a hepatite $\mathrm{B}$, conforme o recomendado, por dificuldade de obtenção da terceira dose.

Corroboram ainda com a tese da importância do envolvimento institucional com a vacinação de seus trabalhadores, os resultados de levantamento da Secretaria Municipal de Saúde do Estado do Rio de Janeiro, no qual se constatou a notificação de 1310 acidentes ocupacionais com materiais pérfuro-cortantes na presença de sangue e secreções entre Janeiro de 1997 e Agosto de 1998, em 49 unidades de saúde (Postos e centros de saúde e hospitais). Dos profissionais acidentados somente $37,6 \%$ eram vacinados contra a hepatite $B$, não obstante a disponibilidade gratuita da vacina nos centros de saúde do município (RAPPARINI 1998).

PASTERNACK et al. (1991), em contrapartida, referem que chegaram a resultados satisfatórios quanto à aceitação e extensão da cobertura vacinal, com programa de vacinação contra a hepatite B implantado no Hospital da Real Sociedade Portuguesa de Beneficência em São Paulo. De 554 indivíduos selecionados para receberem a vacina, $520(93,6 \%)$ completaram todo o programa. Um resultado, de acordo com os autores, comparável com as melhores séries internacionalmente publicadas, atribuidos pelos pesquisadores à execução da vacinação de forma sistematizada no próprio local de trabalho, durante o expediente.

Por outro lado, em referência especificamente aos quantitativos da presença de rotinas hospitalares de vacinação para hepatite B em hospitais, podemos citar dados, a título de comparação com os nossos índices, situados em 36\%, que contrastam, para melhor, com os percentuais aqui alcançados.

BELTRAMI et al. (2000) referem, por exemplo, pesquisa da OSHA, desenvolvido ainda em 1990, nos Estados Unidos, que detectou a presença das referidas rotinas em $91,0 \%$ dos hospitais nos quais se empreendeu o estudo.

THOMPSON e NORRIS (1999), procedendo pesquisa no Estado de Victoria, na Austrália verificaram, numa amostra de $30 \%$ dos hospitais públicos, privados, de pequeno, médio e grande porte, de ensino ou não, incluindo-se instituições localizadas 
em grandes e pequenas cidades, que $91 \%$ dos hospitais ofereciam vacina contra hepatite B para seus trabalhadores e 86\% dispunham de normas escritas acerca da rotina de vacinação de seus profissionais contra o HBV. Os autores observaram, todavia, que em várias instituições havia maior clareza quanto aos protocolos pós- exposição à hepatite $B$ do que propriamente de uma rotina de imunização dos profissionais. Isso porque, ao procederem uma análise qualitativa das normas existentes, puderam perceber que apenas $24,13 \%$ dos documentos considerados pelos dirigentes hospitalares como protocolos de vacinação de fato o eram. Os demais referiam-se a medidas pósexposição, informações genéricas sobre vacinação, instruções acerca de práticas seguras de trabalho e material educacional. Os resultados da pesquisa levaram os autores a concluírem que existiam falhas e inconsistências nas rotinas de imunizações de profissionais para a hepatite B nos hospitais estudados, o que certamente levaria ao insucesso na proteção dos profissionais para a doença.

Em sintese, depreendemos da literatura pertinente, que nossos achados, embora absolutamente não alvissareiros no que concerne à presença mais efetiva das instituições no que concerne a rotina de vacinação para a hepatite $\mathrm{B}$ dos trabalhadores nelas engajados, possivelmente façam parte de um contexto pouco mais generalizado.

No que concerne à realização de PPD periódico em profissionais não reatores envolvidos na prática assistencial em áreas consideradas de risco para a tuberculose como prontos-socorros, nos quais se incluem áreas de inaloterapia, ambulatórios clínicos e até outros mais específicos, presentes em pelo menos duas instituições hospitalares, como setores de broncoscopia, observamos, no presente estudo, que a prática não se constitui rotina em nenhum dos hospitais pesquisados, dado esse que ilustra que a problemática da tuberculose ocupacional não parece fazer parte das preocupações nos serviços visitados.

Embora não tenhamos dados que permitam comparar a realização dos referidos exames em instituições nacionais com vistas à uma programação de prevenção de tuberculose ocupacional, cumpre nos citar as reflexões de SIQUÉRIA (2001) que lembra que a doença é prevalente em nosso meio e vem aumentando sua incidência relacionada ao 
crescimento do número de casos de concomitância com o HIV e às dificuldades clínicas, propedêuticas e terapêuticas. $\mathrm{O}$ autor chama a atenção ainda para o fato de que, nos hospitais, além de ser comum a demora em se estabelecer o diagnóstico e instituir as medidas de isolamento corretas e de tratamento adequado, praticamente inexistem programas de controle da tuberculose que incluam rotinas e procedimentos adequados à proteção eficaz do trabalhador. Complementa que, por ocasião da admissão de funcionário ao emprego em hospital que envolva contato direto com pacientes, recomenda-se a realização de PPD e, se o resultado for negativo, a aplicação da vacina BCG, exceto nos imunodeprimidos e grávidas.

SCHNEIDER (1996), de igual modo, defende a realização do PPD admissional, por considerá-lo como ponto de partida para a detecção dos trabalhadores susceptíveis à doença e também para a determinação da sua incidência, desconhecida nos trabalhadores de saủde dos hospitais nacionais. As finalidades da realização do PPD são, para esse estudioso, identificar os indivíduos não reatores (susceptíveis), vaciná-los e rastrear os reatores (naturais/vacinados) e investigá-los, verificando se estão ou não infectados. Devem ser incluídos na análise todos os trabalhadores que têm possibilidade de contato direto e frequiente com pacientes em unidades de internação: médicos, equipe de enfermagem, técnicos de laboratório, pessoal da limpeza e auxiliares de nutrição (copeiras). O autor ressalta ainda que, considerando o período da validade da vacina $\mathrm{BCG}$, de dez a quinze anos e que esta é ministrada às crianças aos sete anos de idade, $80 \%$ da população vacinada que tem atualmente mais de vinte e dois anos, está teoricamente desprotegida da enfermidade. Tendo-se em conta que a idade de se empregar é comumente após os dezoito anos, o autor conclui que no Brasil, $80 \%$ da população vacinada que trabalha nos hospitais é atualmente susceptível à infecção. Somando-se a esse percentual, reflete o pesquisador, os $20 \%$ de vacinados que não tiveram resposta protetora e os que não se vacinaram, tem-se a possibilidade de $100 \%$ dessa população encontrar-se atualmente exposta aos riscos comunitários e ocupacionais da infecção.

Corroboram com assertiva da importância da realização de PPD em profissionais atuantes em serviços de saúde as próprias recomendações da OSHA, nos Estados 
Unidos, que postula que os hospitais americanos proceda à realização de PPD admissional e a cada seis meses, para os trabalhadores de saúde em freqüente contato com pacientes com tuberculose ou em atividades de alto risco de exposição, como unidades que realizam broncoscopias, laboratórios e prontos socorros e, segundo, faça teste anual para os demais profissionais .

SEPKOWITZ et al. (1997), enfatizam que a realização de PPD constitui-se na pedra angular de um programa de controle de tuberculose, não obstante as dificuldades inerentes à aplicação e interpretação dos exames. Os mesmos autores enfatizam que, nos Estados Unidos, a própria conversão tuberculínica é considerada uma "injúria ocupacional" e que tem que ser notificada aos órgãos de direito.

Cumpre referir RAAD et al. (1989), em contrapartida, que chamam a atenção para o fato de que, embora a maioria das instituições americanas venham incluindo o PPD anual para suas equipes hospitalares, há que se lembrar das próprias recomendações do CDC e da American Thoracic Society, que estabelecem que a necessidade da continuidade da realização de PPD periódico precisa ter como base a incidência da tuberculose na instituição e na comunidade, bem como na taxa institucional de conversão. Isso quer dizer, resumem os autores, que em hospital que raramente admite pacientes com tuberculose e atende à uma comunidade com uma baixa prevalência de infecção tuberculosa, PPD anual dos funcionários não deve ser indicado. Isso porque o próprio $\mathrm{CDC}$, refletem os autores, estabelece que os profissionais não necessitam repetir o PPD, se a incidência de tuberculose na comunidade e no hospital mostra-se muito baixa e se o funcionário não tiver sido exposto a nenhum caso de tuberculose confirmada. Destacam ainda, em suma, que estudos de custo-benefício devam ser empreendidos antes da instituição da prática como rotina.

De todo o exposto vale dizer que embora tenhamos nos restringido à análise da realização ou não de PPD periódico de funcionários com vistas a promoção de um contexto favorável à prevenção da tuberculose ocupacional nos hospitais visitados, e que nossos resultados mostraram-se pouco alentadores, ainda assim outros elementos devem fazer parte de uma análise mais consubstanciada do tema em foco, dentre eles 
certamente afiguram-se estudos de prevalência da doença na comunidade a que servem os hospitais sob análise bem como a própria prevalência da infecção nos pacientes atendidos nas mesmas instituições hospitalares.

\subsection{Isolamentos de pacientes}

Verificamos que nenhuma das instituições incluídas neste estudo dispõe de infra estrutura física específica para a instalação de isolamento de pacientes. Quadro que demonstra frágil situação dos serviços hospitalares relativa ao atendimento de pacientes com doenças transmissíveis, independentemente das categorias dos serviços, sejam eles públicos, privados, filantrópicos, de pequeno, médio ou grande porte, dirigidos ao atendimento geral ou especializado e, ainda, dispondo ou não de organizações que intentem o controle das infecções hospitalares ou, em outras palavras com ou sem $\mathrm{CCIH}$ ou grupo executor de controle das mesmas infecções e, consequentemente, também debilidade à proteção dos profissionais da saúde envolvidos com a assistência de pacientes para os quais o procedimento é indicado. Assim a inexistência das referidas acomodações remete à três possibilidades quando do atendimento de pacientes cujo isolamento é indicado, a primeira delas recai sobre tentativas de adaptações nas ambiências que nem sempre constituem-se das mais adequadas, haja vista as próprias limitações de infra estrutura física dos aposentos como quartos sem porta, sem janelas, dentre outras, a segunda recai sobre a não instalação dos cuidados e a terceira sobre a tentativa, nem sempre com sucesso, de transferência dos pacientes para outros hospitais. Observamos que todas as alternativas podem colocar em risco os profissionais assistentes e mesmo os próprios pacientes.

Por outro lado, cumpre-nos observar complementarmente que embora não se disponha de infra estrutura compatível, em $76 \%$ dos hospitais referiu-se isolar pacientes com quadro de tuberculose.

Os dados detectados levam-nos a afirmar que a situação regional dos hospitais em estudo mostra-se aquém inclusive de outras realidades nacionais no que diz respeito à existência mesma de melhor infra-estrutura para a instituição dos referidos isolamentos. 
Demonstra-se ainda divergente no que diz respeito à própria diferenciação hospitalar que toca às categorias dos serviços.

Embora não tenhamos muitos estudos que tratem da presença de isolamentos em hospitais, pesquisa de OLIVEIRA(1997), por exemplo, desenvolvido na região de Campinas - SP, demonstra constituir-se esse setor como importante na diferenciação dos tipos de hospitais. Nesse trabalho a autora constata tendência de que os hospitais públicos detenham os melhores resultados.

Em nosso estudo, ao contrário, todas as instituições se nivelam na absoluta ausência desse importante aparato de proteção tanto dos usuários como também dos próprios trabalhadores hospitalares. Cabe ainda a observação de que pudemos constatar nas visitas aos hospitais que pelo menos um deles, público, de grande porte, dispõe de aposentos que permitiriam perfeitamente ajustes para subsequente uso como isolamentos. Não se observou, contudo, nenhuma iniciativa nesse sentido, o que nos leva a crer que parece que esse também não é um aspecto que vem preocupando os dirigentes hospitalares.

Sobre a importância de que se leve em conta as estruturas atinentes aos isolamentos na configuração de um aparato de adequado controle das infecções em hospitais tanto no sentido de proteção dos usuários mas também, conforme já referido dos profissionais atuantes nos serviços, tomamos as observações de HUSKINS et al. (1996) que afirmam que o sistema de isolamento que inclui os aspectos relativos à sua infra-estrutura é componente essencial de qualquer programa de controle de infecções hospitalares. Ponderam, contudo, que reveste-se de importância a sua adequação às características das instituições.

Não seria redundante ressaltarmos que no caso de nossos resultados não se verificam sequer tentativas de adequação às características das instituições mas, registramos mais uma vez, a completa ausência das infra estruturas em tela.

Também PONCE DE LEON e FRAUSTO (1997), enfatizam, muito embora tratando mais especificamente de normas, a importância de que o isolamento seja determinado 
de acordo com as possibilidades de cada instituição. Ressalvam, todavia, que em países em desenvolvimento, a falta de recursos mais básicos faz com que a adequação da prática seja quase impossível, aumentando o risco de transmissão de doenças aos trabalhadores de saúde. Permitimo-nos referir assim que a realidade por nós encontrada vem ao encontro do que ponderam aqueles autores.

\subsection{Desempenho geral dos hospitais quanto à presença do conjunto de itens considerados para fins de análise da estrutura concernente à biossegurança nas atividades assistenciais.}

Não obstante devamos levar em conta as limitações, conforme já citado, de se criteriar elementos que possam, no seu conjunto, configurar a qualidade da estrutura de biossegurança na prática assistencial em hospitais podemos, contudo, face aos resultados, afirmar que a precariedade da organização hospitalar nos serviços pesquisados é evidente.

Quando tomamos as médias de presença dos itens aqui levados em conta, verificamos que, mesmo dentre os hospitais mais bem posicionados, ou seja, aqueles que detém maior número de assertivas positivas aos itens considerados para fins de estudo, os resultados não chegam nem a $70 \%$ de presença dos itens e, ainda, somente duas instituições aproximam-se dessa média. Três outras instituições apresentam médias entre $52 \%$ e $44 \%$ e as demais não alcançam nem $40 \%$ de presença dos itens considerados.

Evidenciamos, todavia, diferenças estatisticamente significativas quando os hospitais são classificados por porte, com tendência a serem maiores os percentuais de presença dos itens conforme maiores as instituições. Já por características jurídico-financeiras, os melhores resultados são para os hospitais filantrópicos, seguidos dos privados e, por último, dos públicos. 
Esse modesto desempenho dos hospitais vinculados diretamente ao poder público pode ser explicado, em parte, pela coincidência de que a maioria dessas instituições constituam-se em serviços de pequeno porte, que, na análise por número de leitos, obtiveram também os resultados mais modestos. As citadas instituições são ainda, na sua grande maioria, aquelas localizadas fora da cidade de Itabuna as quais obtiveram, de igual modo, os piores resultados.

Como resultante desses fatores apontamos a possibilidade de dois efeitos. O primeiro deles relativo à menor complexidade de atendimento nas instituições pequenas, o que permite deduzir uma falsa idéia de baixo risco e, por conseguinte, maior fragilidade organizacional. $\mathrm{O}$ outro relativo ao distanciamento dos maiores centros, com as dificuldades inerentes ao acesso às informações por parte dos profissionais seja através de freqüência a cursos ou mesmo a bibliografias atualizadas.

Observamos, também, que é igualmente nas instituições de pequeno porte que menos se encontram CCIHs formalmente instituídas e quando existentes é nelas que verificamos menor tempo de experiência dos enfermeiros nos referidos órgãos, bem como menores percentagens de treinamentos de suas lideranças em biossegurança. Os próprios consórcios em substituição à CCIH, possibilidade prevista na Portaria MS 2.616, são inexistentes. Esses elementos podem colaborar para a maior fragilidade institucional relativa ao assunto aqui em tela.

Cumpre nos citar, entretanto, que quando analisamos a própria presença de CCIH enquanto subsídio para a implementação de normas e rotinas afetas à biossegurança nos hospitais, não conseguimos detectar diferenças estatisticamente significativas entre os serviços com e sem o respectivo órgão, ainda que haja uma tendência de resultados pouco melhores nos nosocômios providos da estrutura em foco.

Em respeito aos hospitais filantrópicos, que na análise geral obtiveram os melhores resultados, convém destacarmos que pelo menos duas dessas instituições, são as que mais obtiveram investimentos, em particular em tempos que a economia local gozava de situação de destaque relacionada aos lucros auferidos pela exportação de cacau. Assim, supomos que construiu-se um patrimônio organizacional, no geral mais bem arranjado 
do que nos demais serviços e que esses investimentos permitem ainda hoje, aliados certamente a outros apoios governamentais, através de programas específicos, não obstante as reveses sofridas pela economia, dar continuidade à uma relativa qualidade assistencial e, via de conseqüência, também nos aspectos da biossegurança aqui considerados.

Por outro lado, se diferenciam das demais, as instituições que se prestam às atividades práticas de cursos de formação e aperfeiçoamento de pessoal da saúde. Assim, podemos aventar que tais serviços, conquanto não se constituam exatamente em hospitais universitários, se beneficiam, de alguma forma, no que se refere à uma melhor estrutura de biossegurança, de suas relações com o ensino. O maior número de treinamentos de pessoal presentes nessas instituições, alguns deles conduzidos pelo próprios discentes, pode ser ilustrativo.

Registre-se, contudo, que a própria escolha das instituições campos de ensino para a saúde, pauta-se, em geral, na seleção dos serviços mais bem providos estruturalmente.

Em contrapartida, os hospitais não se distinguem quando analisados sob o prisma do tipo e predomínio da clientela atendida, bem como do corpo clínico aberto ou fechado. A razão para isso talvez recaia, no primeiro caso, à inexpressiva interferência dos pacientes nas estruturações dos serviços, ainda mais se levarmos em conta que uma estrutura de biossegurança diz mais respeito, pelo menos numa visão mais restritiva do assunto, aos profissionais do que propriamente aos pacientes. Já é praticamente senso comum que os usuários dos serviços de saúde do país têm pouca ou nenhuma interferência sobre até mesmo o seu próprio atendimento, a não ser em aspectos de hotelaria quando clientes em serviços privados. Não é esse o caso dos hospitais aqui em estudo, posto que somente uma das instituições restringe sua atenção a pacientes cujas fontes pagadoras são de convênios privados e pagamentos particulares. Nessa mesma instituição os resultados gerais da estrutura aqui estudada foi inclusive abaixo da média dos demais hospitais, o que reforça a tese de que o tipo de paciente atendido em respeito à fonte pagadora nenhuma influência tem sobre a estrutura de biossegurança, pelo menos na realidade aqui estudada. No segundo caso, ou seja, no que se refere ao corpo 
clínico dos hospitais serem abertos ou fechados, supomos explicação ainda mais direta. Nos parece que os médicos pouco se preocupam com a questão da organização hospitalar relativa à biossegurança. Isso determina que as consequiências sobre o aporte estrutural dos hospitais relativo à biossegurança, em respeito ao tipo de corpo clínico sejam nulas.

Em compensação, a existência de grupo executivo de controle de infecção hospitalar diferencia, com alguma acurácia, as instituições quanto a presença de normas e rotinas em respeito à biossegurança, detendo os melhores resultados conforme já descrito, aquelas que dispõem do grupo. Mister levarmos em conta, entretanto, que as instituições que possuem grupo executivo de controle de $\mathrm{IH}$ são exatamente as instituições maiores. Duas delas filantrópicas, que na análise por vinculação jurídicofinanceira, mostraram-se com resultados pouco mais promissores, apresentam número mais expressivo de trabalhadores, localizam-se na cidade polo da região estudada e são responsáveis pelo atendimento de pacientes de maior complexidade, elementos que não obstante não devessem atuar com relevância na adoção das práticas que visam a proteção dos trabalhadores, posta a importância de que todos os serviços independentemente de suas características mais especificas necessitam dispor de uma estrutura mínima em respeito à questão, podem corroborar para os resultados ora encontrados. Não se invalida, contudo, pelo contrário, que os grupos executores de controle de I.H diferenciam com significância os hospitais no que se refere a essa mesma estrutura. Os resultados demonstram que nos hospitais que dispõem dos respectivos grupos executivos estão mais presentes as normas de biossegurança consideradas para fins do estudo, são desenvolvidos mais treinamentos, existe maior preocupação com os registros, conforme a análise item a item pôde ilustrar.

Também nessas instituições estão presentes as CIPAs, muito embora não tenhamos detectado nenhuma ação propositiva desses órgãos, no que se refere à biossegurança, em especial para agentes biológicos, vide o exemplo da própria elaboração de mapas de risco de sua responsabilidade inclusive legal porém inexistentes nos serviços. 
Conquanto não se tenhamos encontrado trabalhos que comparem as instituições no que se refere especificamente à biossegurança concernentes às estruturas dos serviços, levando-se em conta as características dos hospitais aqui estudados, é possível traçarmos um paralelo com estudos que tratem do controle das infecções hospitalares, mais presentes na literatura.

Dentre eles está o de OLIVEIRA (1997) que conseguiu detectar existência de diferenças nos padrões para controle de infecção, conforme diferentes estratos de categorias hospitalares. Verificou, ao contrário do achados do presente estudo que os hospitais públicos apresentam bom desempenho e qualidade nas atividades de controle de infecção. Encontrou ainda diferenças significativas, com melhores resultados para os serviços hospitalares estatais, quando analisou normatizações mínimas e infra-estrutura de setores, como, por exemplo, dos isolamentos.

A contraposição dos dados de OLIVEIRA e os nossos talvez se explique pelas peculiaridades dos hospitais estudados ainda que agrupados sob uma única denominação- hospital público. Observamos que no caso do estudo da pesquisadora em apreço as médias obtidas pelos hospitais aí classificados possivelmente tenham sido majoradas pela presença de um grande hospital público referência com melhor estrutura e universitário. No caso de nosso estudo, os hospitais públicos, constituem-se, na sua maioria, conforme já citado, de pequeno porte e localizados em pequenas cidades do interior. Além disso pudemos observar apresentam lacunas importantes não somente no que diz respeito à biossegurança, como na falta de médicos, infra estrutura física, em geral precária, quadro de pessoal deficitário dentre outros.

Do exposto podemos afirmar que embora importante a definição de características que permitam diferenciar as instituições, as peculiaridades regionais e dos serviços não podem ser subestimadas.

Também OLIVEIRA detectou melhor desempenho no geral e, especificamente na presença de treinamentos dos componentes dos grupos executores de controle de $\mathrm{IH}$ e de normas nos hospitais universitários, conforme em parte já anunciamos aqui anteriormente. Em nosso estudo, conquanto não se possa categorizar os hospitais que se 
prestam ao ensino como propriamente universitários, porque eles não o são de fato, de igual modo conseguimos detectar diferenciação entre aqueles utilizados pelas instituições de ensino e os demais, conforme referido.

Se nos aspectos concernentes às características dos hospitais no que diz respeito ao seu status jurídico, os resultados por nós encontrados divirjam daqueles de OLIVEIRA, no que toca ao porte das instituições observamos dados também confluentes. A autora identifica um padrão, a dos hospitais menores de 50 leitos, que diferencia significativamente as instituições e chama a atenção pela modéstia, no que concerne ao desempenho relativo à organização das atividades de controle de infecção, presença de normas e infra-estrutura para a viabilização desse mesmo controle. No presente estudo, também as maiores dificuldades no que diz respeito à existência de adequada estrutura de biossegurança são verificadas nas pequenas instituições.

De igual forma CELENTANO et al. (1987), em estudo sobre a difusão e adoção das recomendações do CDC para a prevenção e controle de infecções hospitalares em hospitais americanos encontram diferenças significativas entre grupos de hospitais, observando desempenhos menos adequados nas instituições de pequeno porte. Para os mesmos autores, enquanto a adoção média das medidas cresce na proporção do tamanho dos hospitais, a magnitude das diferenças não se mostra elevada quando se analisam itens em separado, resultados que guardam alguma semelhança com os resultados aqui encontrados. 


\section{RESULTADOS - ESTUDO DO PROCESSO DE TRABALHO - ADESÃO ÀS PRÁTICAS DE AUTO-PROTEÇÃO ENVOLVIDAS NAS PUNÇÕES VENOSAS}

Os resultados encontrados concernentes às práticas de auto-proteção (biossegurança) envolvidas nos procedimentos de punções venosas, delimitados com fins de análise de aspectos referentes ao processo de trabalho, conforme explicita DONABEDIAN (1986), são aqui apresentados.

De início dispomos os achados referentes a cada uma das três instituições nas quais foram procedidas as observações. Posteriormente, seguem tabulação referente aos dados, por unidades observadas nos mesmos hospitais, e menção às aderências aos procedimentos realizados pelas diferentes categorias profissionais e outros itens como: tempo de formação desses profissionais; características do procedimento, enquanto realizado em situação de emergência ou não; conhecimento prévio por parte dos profissionais, do diagnóstico do paciente submetido ao procedimento; idade dos usuários dos serviços e formas de remuneração hospitalar pelo atendimento.

Demonstramos assim na tabela 8 a adesão à prática de lavagem das mãos antes da realização de acessos venosos, uso de luvas, descarte imediato de agulhas, não reencape de agulhas e lavagem das mãos após os procedimentos, nos três hospitais estudados.

Observamos que existem, pelos testes estatísticos empreendidos, diferenças estatisticamente significantes no nível de $0,1 \%(p=0,001)$ entre os hospitais, no que se refere à lavagem prévia das mãos, detendo o melhor resultado o hospital $T$, especializado no atendimento materno-infantil e no qual circunscrevemos nossas observações às unidades de atendimento às crianças. Chama-nos a atenção, todavia, além das diferenças estatísticas de aderência à prática em pauta entre as instituições, os seus modestos percentuais em todos os três hospitais. 
Resultados confluentes com a prática da lavagem das mãos através dos quais também se demonstram diferenças estatisticamente significantes, no nível de $0,1 \%(p=0,001)$ entre as três instituições, com resultados de igual modo, melhores para o hospital $\mathrm{T}$, afigurase a prática do uso de luvas de proteção por parte dos profissionais. O uso de luvas, entretanto, mostra-se ainda menos contumaz que a própria lavagem das mãos.

Com respeito ao descarte imediato de agulhas, também observamos diferenças estatisticamente significativas, no nível de $0,2 \%(p=0,002)$ nas adesões por parte dos profissionais entre os hospitais.

Entretanto, contrariamente ao detectado para a lavagem das mãos antes dos procedimentos e ao uso de luvas para o emprego de técnicas, resultados mais promissores foram encontrados nos hospitais D e L, dirigidos ao atendimento geral e exclusivo de adultos.

Igualmente ao verificado com o cumprimento da lavagem de mãos, uso de luvas e descarte imediato de agulhas após procedimentos de punções, também observamos que o cumprimento da preconização do não re-encape de agulhas ocorre com diferenças estatisticamente significativas, aqui no nível de $0,4 \%(p=0,004)$ de significância entre os hospitais.

Mais uma vez, os hospitais mais bem posicionados são aqueles dirigidos ao atendimento geral e de adultos (hospitais $\mathrm{D}$ e L) a despeito do hospital $\mathrm{T}$, dirigido à assistência materno infantil e nos quais nos ativemos a observações em unidades destinadas aos cuidados de infantes.

Quando se analisa, a prática de lavagem das mãos, por parte dos profissionais, após a realização dos procedimentos de punção, no geral, observamos diferenças estatisticamente significativas no nível de $0,3 \% \quad(p=0,003)$. Resultados mais apropriados, ainda que modestos, são encontrados no hospital $\mathrm{T}$. 
Tabela 8 - Adesão às práticas de auto-proteção em procedimentos de acesso venoso de pacientes, por profissionais de saúde, em três hospitais da cidade de Itabuna. Itabuna-Ba. 2002.

\begin{tabular}{|c|c|c|c|c|c|c|c|c|c|c|c|c|c|c|c|}
\hline \multirow{3}{*}{ Hospitais } & \multicolumn{3}{|c|}{ Lavagem prévia das mãos } & \multicolumn{3}{|c|}{ Uso de luvas } & \multicolumn{3}{|c|}{$\begin{array}{l}\text { *Descarte imediato de } \\
\text { agulhas }\end{array}$} & \multicolumn{3}{|c|}{ Não re-encape } & \multicolumn{3}{|c|}{$\begin{array}{l}{ }^{* *} \text { Lavagem das mãos após } \\
\text { procedimentos }\end{array}$} \\
\hline & \multicolumn{2}{|c|}{$\operatorname{Sim}$} & \multirow{2}{*}{$\begin{array}{l}\text { Total } \\
* * *\end{array}$} & \multicolumn{2}{|c|}{$\operatorname{Sim}$} & \multirow{2}{*}{$\begin{array}{c}\text { Total } \\
* * *\end{array}$} & \multicolumn{2}{|c|}{$\operatorname{Sim}$} & \multirow{2}{*}{$\begin{array}{l}\text { Total } \\
* * *\end{array}$} & \multicolumn{2}{|c|}{ Sim } & \multirow{2}{*}{$\begin{array}{c}\text { Total } \\
* * *\end{array}$} & \multicolumn{2}{|c|}{ Sim } & \multirow{2}{*}{$\begin{array}{l}\text { Total } \\
* * *\end{array}$} \\
\hline & $\mathrm{N}^{\circ}$ & $\%$ & & N. ${ }^{\circ}$ & $\%$ & & N. ${ }^{\circ}$ & $\%$ & & N.o & $\%$ & & N. ${ }^{\circ}$ & $\%$ & \\
\hline D & 48 & 30.8 & 156 & 19 & 12,2 & 156 & 79 & 94,0 & 84 & 76 & 90.5 & 84 & 48 & 32,6 & 147 \\
\hline $\mathbf{L}$ & 56 & 46.7 & 120 & 13 & 10.8 & 120 & 53 & 84,1 & 63 & 45 & 71.4 & 63 & 46 & 40,3 & 114 \\
\hline $\mathbf{T}$ & 43 & 68.2 & 63 & 27 & 42.9 & 63 & 22 & 68.7 & 32 & 20 & 62.5 & 32 & 35 & 59.3 & 59 \\
\hline Total & 147 & 43.4 & 339 & 59 & 17.4 & 339 & 154 & 86.0 & 179 & 141 & 78.8 & 179 & 129 & 40.3 & 320 \\
\hline
\end{tabular}

* Consideramos como descarte imediato, a situação na qual uma vez finda a punção, essa foi seguida de imediato descarte de agulha antes de se encadear qualquer outra atividade. Não levamos em conta, todavia, se a agulha foi ou não re-encapada antes do descarte.

** O número de lavagem de mãos após a realização dos procedimentos de punção não coincide com o número de procedimentos de punções realizadas, porque em dezenove oportunidades, por interferência do meio, não foi possível observar se o profissional lavou ou não as mãos após a execução da punção.

*** Número total de procedimentos observados 
Procedendo-se à análise da adesão às preconizações relativas às medidas de autoproteção durante a realização de punções venosas, em diferentes setores dos hospitais, verificamos, para a lavagem das mãos antes dos procedimentos, percentuais expressivos em berçário (91,3\% de lavagem prévia das mãos) e UTE - unidade de atendimento especial pediátrico $(100,0 \%)$, devendo-se registrar, entretanto, que o número de eventos observados nessa última unidade, muito diminuto (apenas dois), não permite maiores aprofundamentos.

Observemos ainda na tabela 9 que a prática da lavagem prévia das mãos apresentou-se mais contumaz, para os procedimentos realizados nos prontos socorros $(41,8 \%)$ do que nas unidades de internação $(33,7 \%)$. As diferenças de adesão à prática entre as unidades ocorrem com significância estatística menor que $0,1 \%(p<0,001)$.

Verificamos o mesmo fenômeno para o uso de luvas para a realização dos procedimentos em apreço. Novamente, no berçário e na UTE, a prática mostra-se mais freqüentemente empregada, com respectivamente, 65,2 e 100,0\% de presença, a despeito das alas de internação $(23,6 \%)$ e prontos-socorros $(9,3 \%)$.

No concernente ao descarte imediato de agulhas após os procedimentos, observamos que esses ocorrem com diferenças estatisticamente significativas, em níveis menores que $0,1 \%(p=0,001)$, quando se analisa as técnicas nas diferentes unidades. Aqui, todavia, os melhores indices são observados nos prontos socorros $(94,8 \%)$ e UTE pediátrica $(100,0 \%)$, seguidos pelo berçário $(86,7 \%)$ e alas de internação $(63,8 \%)$.

Verificação parecida ocorre com a técnica de não re-encape de agulhas após o uso. Uma vez mais, resultados mais aproximados do ideal são encontrados nos prontos socorros e UTE pediátrica. Berçário e alas de internação apresentam-se com percentuais similares para o evento. 
Tabela 9 - Adesão às práticas de auto-proteção em procedimentos de acesso venoso de pacientes, por profissionais da saúde, em três hospitais da cidade de Itabuna, de acordo com diferentes setores hospitalares. Itabuna-Ba, 2002.



*número total de procedimentos 
No que diz respeito à lavagem das mãos após a realização dos procedimentos em foco, invertem-se os indices de adesão. Observamos, contudo, diferenças estatisticamente significativas em níveis de $0,1 \%(p=0,001)$. Berçário e UTE pediátrica apresentam melhores adesões $(85,7 \%$ e $100,0 \%$, respectivamente), seguidos, com relativa distância, da aderência à prática observada nas alas de internação $(37,9 \%)$ e prontos socorros $(36,2 \%)$.

Quando nos atemos às adesões às práticas, conforme tabela 10, nos diferentes setores dentro de um mesmo hospital, verificamos que no hospital D, embora sem distinções estatisticamente significantes, maiores percentuais de lavagem das mãos previamente aos procedimentos, ainda que ressaltemos os modestíssimos resultados, no pronto socorro do que na ala de internação de pacientes. O mesmo ocorre, nos hospital L e T se bem com diferenças estatisticamente significantes, com níveis menores que $1 \%$ $(p<0,01)$.

No hospital T, destacam-se, conforme já citado, o berçário e UTE, seguidos, com distância razoável, pelo pronto socorro e setor de internamento infantil.

O uso de luvas, ao contrário, mostra-se menos freqüente nos prontos socorros do que nas alas de internamento, nos hospitais $D$ e $L$, com diferenças estatisticamente significantes, nos níveis de $3 \%(p=0,03)$ e $7 \%(p=0,07)$, respectivamente. No hospital $\mathrm{T}$, também se mostram com diferenças estatisticamente significantes, menor que $1 \%$ $(p<0,01)$ as adesões ao uso de luvas entre os setores. Maiores percentuais de aderência são verificados no berçário e UTE seguindo-se as alas de internamento e por último o pronto socorro.

Observamos ainda que o descarte imediato de agulhas ocorre com diferenças estatisticamente significantes, nos niveis de $8 \%(p=0,08)$, menor que $1 \%(p<0,01)$ e $4 \%$ $(p=0,04)$, respectivamente para os hospitais $\mathrm{D}, \mathrm{L}$ e $\mathrm{T}$, quando comparados, os seus respectivos setores, internamente. 
Tabela 10 - Aderência a práticas de auto-proteção envolvidas nos procedimentos de punção venosa nos diferentes setores dos hospitais estudados. Itabuna-Ba. 2002.

\begin{tabular}{|c|c|c|c|c|c|c|c|c|c|c|c|c|c|}
\hline \multirow{3}{*}{ Ilospitais } & \multirow{3}{*}{ Práticas } & \multicolumn{3}{|c|}{ Ala de Internação } & \multicolumn{3}{|c|}{ Pronto socorro } & \multicolumn{3}{|c|}{ UTI pediátrica } & \multicolumn{3}{|c|}{ Berçário } \\
\hline & & \multicolumn{2}{|c|}{$\operatorname{Sim}$} & \multirow{2}{*}{$\begin{array}{c}\text { Total } \\
*\end{array}$} & \multicolumn{2}{|c|}{ Sim } & \multirow{2}{*}{$\begin{array}{c}\text { Total } \\
*\end{array}$} & \multicolumn{2}{|c|}{ Sim } & \multirow{2}{*}{$\begin{array}{c}\text { Total } \\
*\end{array}$} & \multicolumn{2}{|c|}{ Sim } & \multirow{2}{*}{$\begin{array}{c}\text { Total } \\
*\end{array}$} \\
\hline & & N. & $\%$ & & N. ${ }^{\circ}$ & $\%$ & & N. & $\%$ & & $\mathrm{~N} .^{\circ}$ & $\%$ & \\
\hline \multirow[t]{5}{*}{ D } & Lavagem prévia das mãos & 2 & 18,2 & 11 & 46 & 31.7 & 145 & - & - & - & - & - & - \\
\hline & Uso de luvas & 4 & 36,4 & 11 & 15 & 10.3 & 145 & - & - & - & - & - & - \\
\hline & Descarte imediato de agulhas utilizadas & 7 & 77.8 & 9 & 72 & 96.0 & 75 & - & - & - & - & - & - \\
\hline & Nào re-encape de agulhas & 7 & 77.8 & 9 & 69 & 92.0 & 75 & - & - & - & - & - & - \\
\hline & Lavagem das mãos após realização dos procedimentos & 4 & 36.4 & 11 & 44 & 32.3 & 136 & - & - & - & - & - & - \\
\hline \multirow[t]{5}{*}{$\mathbf{L}$} & Lavagem prévia das mãos & 11 & 24.4 & 45 & 45 & 60.0 & 75 & - & - & - & - & - & - \\
\hline & Uso das luvas & 8 & 17.8 & 45 & 5 & 6,7 & 75 & - & - & - & - & - & - \\
\hline & Descarte imediato de agulhas utilizadas & 16 & 66.7 & 24 & 37 & 94.9 & 39 & - & $\cdot$ & - & - & - & - \\
\hline & Nào re-encape de agulhas & 12 & 57.1 & 21 & 33 & 78,6 & 42 & - & - & - & - & - & - \\
\hline & Lavagem das mãos após realização dos procedimentos & 16 & 36.4 & 44 & 30 & 42.9 & 70 & - & - & - & - & - & - \\
\hline \multirow[t]{5}{*}{$T$} & Lavagem prévia das mãos & 17 & 51.5 & 33 & 3 & 60,0 & 5 & 2 & 100.0 & 2 & 21 & 91.3 & 23 \\
\hline & Uso das luvas & 9 & 27.3 & 33 & 1 & 20,0 & 5 & 2 & 100,0 & 2 & 15 & 65.2 & 23 \\
\hline & Descarte imediato de agulhas utilizadas & 7 & 50.0 & 14 & 0 & 0.0 & 1 & 2 & 100.0 & 2 & 13 & 86.7 & 15 \\
\hline & Não re-encape de agulhas & 8 & 57.1 & 14 & 1 & 100,0 & 1 & 2 & 100.0 & 2 & 9 & 60.0 & 15 \\
\hline & Lavagem das mãos após realização dos procedimentos & 13 & 40.6 & 32 & 2 & 50.0 & 4 & 2 & 100.0 & 2 & 18 & 85.7 & 21 \\
\hline
\end{tabular}

*Número total de procedimentos 
Nas duas primeiras instituições, as maiores adesões são observadas nos prontos socorros, a despeito das alas de internação. No último, os melhores resultados são verificados no berçário, em contraponto aos setores de internação. No pronto socorro e UTE, o número de eventos observados foi muito diminuto para permitir uma análise mais acurada.

Por outro lado, o não re-encape de agulhas, embora mais observado no pronto socorro do que no setor de internamento, não ocorre com diferenças estatisticamente significativas no hospital D. Diferenças no nível de $9 \%(p=0,09)$ é calculada para o hospital L, que, igualmente ao verificado no hospital D, apresenta maiores percentuais de adesão à técnica preconizada, no pronto socorro em contrapartida ao setor de internamento de pacientes.

No hospital T, a adesão observada em relação a técnica em foco não ocorre com discrepância entre os diferentes locais de atendimento na instituição, diferente da prática da lavagem das mãos após a realização dos procedimentos que ocorre com diferenças estatisticamente significativas, em níveis menores que $1 \%(p<0,01)$ e cujos percentuais mostram-se bem mais arrojados no berçário $(85,7 \%)$ e UTE (100,0\%), sempre lembrando a baixa qualidade amostral desse último setor.

Nos hospitais D e L, ao contrário, não se detectam diferenças estatisticamente significativas dentre os setores, para a lavagem das mãos após os procedimentos de punções venosas de pacientes.

Analisando os procedimentos realizados pelas diferentes categorias profissionais, cujas percentagem de adesões podem ser visualizados na tabela 11, verificamos que a lavagem das mãos antes do empreendimento ocorre com diferenças estatisticamente significativas, no nivel de $2 \% \quad(p=0,02)$ para as classes consideradas, ou seja, os profissionais médicos, enfermeiros e auxiliares e técnicos de enfermagem.

Mister, contudo, levarmos em conta a modesta amostra de eventos observados para enfermeiros e médicos, conforme já citado. De qualquer sorte, cumpre-nos referir que 
$77,8 \%$ dos procedimentos levados a cabo por enfermeiros foram precedidos da lavagem das mãos, contra $42,9 \%$ dos eventos empreendidos por auxiliares e técnicos de enfermagem e $0 \%$ dos levados a efeito por médicos.

Para o uso de luvas, também verificamos diferenças estatisticamente significativas, aqui em níveis menores que $1 \%(p<0,01)$. Somente quatro procedimentos foram realizados por médicos (duas instalações de intra caths e duas punções com gelco) e em todos foram utilizadas luvas pelos profissionais. Observamos a execução de nove procedimentos por enfermeiros e em três $(33,3 \%)$ verificamos o uso do EPI.

Os procedimentos de punção presenciados foram realizados, com forte preponderância, pelos auxiliares e técnicos de enfermagem, conforme já citado e o uso de luvas para essa categoria profissional foi de somente $15,9 \%$.

Concernente ao cumprimento da preconização de se descartar de imediato as agulhas utilizadas nas punções venosas, detectamos diferenças estatisticamente significativas, no nível de $13 \%(p=0,13)$, entre as categorias profissionais. Nos dois únicos procedimentos médicos para os quais cabiam essa providência, elas não foram executadas, mas as foram nas seis $(100,0 \%)$ empreendidas pelos enfermeiros.

Dos procedimentos que demandavam o descarte de agulhas, 86,5\% foram realizados corretamente pelos auxiliares e técnicos de enfermagem, ou seja, executadas as punções, as agulhas foram prontamente descartadas.

No tocante à adesão à preconização de não re-encape de agulhas após a realização de procedimentos envolvendo acessos venosos, não detectamos, pelos testes estatísticos empreendidos, diferenças significativas entre as categorias profissionais. Os dois únicos procedimentos médicos observados, os quais envolviam a preconização, foram executados com correção, o mesmo se dando com as seis técnicas executadas pelos enfermeiros.

Os procedimentos realizados por auxiliares e técnicos de enfermagem estavam corretos no aspecto atinente, em $77,3 \%$ das oportunidades observadas. 
Tabela 11 - Aderência a práticas de auto-proteção envolvidas em procedimento de punções venosas, por diferentes categorias profissionais em hospitais da cidade de Itabuna. Itabuna-Ba.2002.

\begin{tabular}{|c|c|c|c|c|c|c|c|c|c|c|c|c|c|c|c|}
\hline \multirow{3}{*}{$\begin{array}{l}\text { Categorias } \\
\text { profissionais }\end{array}$} & \multicolumn{3}{|c|}{ Lavagem prévia das mãos } & \multicolumn{3}{|c|}{ Uso de luvas } & \multicolumn{3}{|c|}{ Descarte imediato de agulhas } & \multicolumn{3}{|c|}{ Não re-encape de agulhas } & \multicolumn{3}{|c|}{$\begin{array}{l}\text { Lavagem das mãos após } \\
\text { procedimentos }\end{array}$} \\
\hline & \multicolumn{2}{|c|}{ Sim } & \multirow{2}{*}{$\begin{array}{c}\text { Total } \\
*\end{array}$} & \multicolumn{2}{|c|}{ Sim } & \multirow{2}{*}{$\begin{array}{c}\text { Total } \\
*\end{array}$} & \multicolumn{2}{|c|}{ Sim } & \multirow{2}{*}{$\begin{array}{c}\text { Total } \\
*\end{array}$} & \multicolumn{2}{|c|}{ Sim } & \multirow{2}{*}{$\begin{array}{c}\text { Total } \\
*\end{array}$} & \multicolumn{2}{|c|}{ Sim } & \multirow{2}{*}{$\begin{array}{c}\text { Total } \\
*\end{array}$} \\
\hline & $N^{0}$ & $\%$ & & $\mathrm{~N}^{\circ}$ & $\%$ & & N. ${ }^{\circ}$ & $\%$ & & $\mathrm{~N}^{\circ}$ & $\%$ & & N. ${ }^{\circ}$ & $\%$ & \\
\hline $\begin{array}{l}\text { Auxiliares/Técnicos de } \\
\text { Enfermagem }\end{array}$ & 140 & 42,9 & 326 & 52 & 15.9 & 326 & 148 & 86,5 & 171 & 133 & 77,7 & 171 & 123 & 39,9 & 308 \\
\hline Enfermeiros & 7 & 77,8 & 9 & 3 & 33,3 & 9 & 6 & 100,0 & 6 & 6 & 100,0 & 6 & 4 & 44,4 & 9 \\
\hline Médicos & 0 & 0 & 4 & 4 & 100,0 & 4 & 0 & 0 & 2 & 2 & 100,0 & 2 & 2 & 66,7 & 3 \\
\hline Total & 147 & 43.4 & 339 & 59 & 17,4 & 339 & 154 & 86.0 & 179 & 141 & 78.7 & 179 & 129 & 40.3 & 320 \\
\hline
\end{tabular}

* número total de procedimentos 
A lavagem das mãos após a execução dos procedimentos em foco neste estudo também não ocorreu com diferenças significativas entre as categorias profissionais cujos procedimentos puderam ser observados.

Observemos que a baixa qualidade amostral dos procedimentos analisados, em particular os executados pelos médicos, mas também pelos enfermeiros, atuam certamente de forma a não dimensionar, a contento, os resultados.

Quando se atém, por outro lado, à aderência às práticas preconizadas, levando em conta o sexo dos profissionais, não detectamos diferenças estatisticamente significativas, exceto para a lavagem das mãos após a realização dos procedimentos em foco, observada com maior freqüência e com distinção significativa no nível de $15,0 \%$ $(p=0,15)$ pelos testes estatísticos empreendidos, para os eventos executados por profissionais do sexo feminino. Dos 320 procedimentos observados, 260 foram executados por profissionais do sexo feminino e em $42,3 \%$ das oportunidades, foram observadas a lavagem das mãos. 60 procedimentos foram executados por profissionais do sexo masculino e, em apenas $31,7 \%$ das oportunidades observou-se a higienização em pauta.

No geral, também o tempo de formado dos profissionais não se mostra elemento distintivo na adesão às práticas aqui estudadas. Chama-nos à atenção, entretanto, que os profissionais que se formaram entre cinco à dez anos apresentam-se mais aderentes à lavagem das mãos antes dos procedimentos, com diferenças estatisticamente significativas, no nível de $1,4 \%(p=0,014) \cdot 75,0 \%$ dos profissionais com tempo de formado de cinco à dez anos tiveram média individual de adesão à prática, superior à mediana $(+\mathrm{m})$ obtida pelo conjunto das médias individuais do respectivo grupo de profissionais . Para os profissionais formados há menos de cinco anos o $+\mathrm{m}$ foi igual a $40 \%$ e há mais de dez anos $+\mathrm{m}=38 \%$.

A freqüência da lavagem das mãos antes da realização dos procedimentos mostrou-se, por outro lado, numericamente mais expressiva e com distinções estatisticamente 
significativas, em niveis menores que $1 \%(p<0,01)$, quando conhecidos os diagnósticos dos pacientes por parte dos profissionais (Tabela12).

As demais medidas como uso de luvas, descarte imediato e não re-encape de agulhas, bem como a lavagem das mãos após a realização dos procedimentos não se apresentaram com distinções estatisticamente significantes, conhecidas ou não as condições diagnósticas dos usuários dos serviços de saúde submetidos aos procedimentos em estudo.

Em respeito à lavagem das mãos antes da realização de punções venosas, não se verificaram distinções estatisticamente significativas, quando levado em conta o caráter de urgência ou de rotina dos procedimentos, muito embora resultados mais promissores tenham sido observados nas situações mais rotineiras, conforme tabela 12

Quanto ao uso de luvas, ao contrário, foi observado uso mais freqüente nas emergências do que nas punções rotineiras, havendo ainda, distinções estatisticamente significativas em níveis menores que $1 \%(p<0,01)$, quando comparadas as duas situações. Observamos, contudo, que as agulhas são mais prontamente descartadas em situações de rotina do que em urgências, com diferenças significativas no nivel de $6 \%(p=0,06)$.

Em contrapartida, a prática preconizada de não se re-encapar as agulhas, mostrou-se, ainda que sem distinções estatisticamente significativas, mais adotada em situações de punções emergenciais do que nos procedimentos mais rotineiros.

Fenômeno similar, embora com distinções estatisticamente significativas, no nivel de $9 \%(p=0,09)$, foi observado para a lavagem das mãos após a realização dos procedimentos, sendo que a prática mostrou-se mais contumaz pós realização de punção em situação de emergência do que de rotina. 
Tabela 12 - Procedimentos envolvendo o emprego de medidas de auto-proteção de acordo com o conhecimento ou não do diagnóstico do paciente, condição de execução do procedimento (Rotina/Urgência), tipo de remuneração hospitalar pelo atendimento em hospitais da cidade de Itabuna. Itabuna-Ba. 2002.

\begin{tabular}{|c|c|c|c|c|c|c|c|c|c|c|c|c|c|c|c|c|c|c|}
\hline \multirow{3}{*}{ Procedimentos } & \multicolumn{3}{|c|}{$\begin{array}{l}\text { Conhecimento do } \\
\text { diagnóstico }\end{array}$} & \multicolumn{3}{|c|}{ Diagnóstico desconhecido } & \multicolumn{3}{|c|}{ Rotina } & \multicolumn{3}{|c|}{ Urgência } & \multicolumn{6}{|c|}{ Forma de remuneração hospitalar pelo atendimento } \\
\hline & \multicolumn{2}{|c|}{ Adesão } & \multirow{2}{*}{ Total } & \multicolumn{2}{|c|}{ Adesão } & \multirow{2}{*}{ Total } & \multicolumn{2}{|c|}{ Adesão } & \multirow{2}{*}{ Total } & \multicolumn{2}{|c|}{ Adesão } & \multirow{2}{*}{ Total } & \multicolumn{2}{|c|}{ Convènio SUS } & \multirow{2}{*}{ Total } & \multicolumn{2}{|c|}{$\begin{array}{c}\text { Outros } \\
\text { convênióos** }\end{array}$} & \multirow{2}{*}{ Total } \\
\hline & $\mathrm{N}$ & $\%$ & & $N$ & $\%$ & & $N$ & $\%$ & & $\mathrm{~N}$ & $\%$ & & $\mathrm{~N}$ & $\%$ & & $\mathrm{~N}$ & $\%$ & \\
\hline $\begin{array}{l}\text { Lavagem das mãos antes da realização dos } \\
\text { procedimentos }\end{array}$ & 114 & 50.0 & 228 & 33 & 29,7 & 111 & 143 & 44,1 & 324 & 4 & 26,7 & 15 & 135 & 44,5 & 303 & 12 & 33.3 & 36 \\
\hline $\begin{array}{l}\text { Uso das luvas para a realização dos } \\
\text { procedimentos }\end{array}$ & 44 & 19.3 & 228 & 15 & 13,5 & 111 & 51 & 15,7 & 324 & 8 & 53,3 & 15 & 57 & 18,8 & 303 & 2 & 5.5 & 36 \\
\hline Descarte imediato de agullas utilizadas & 98 & 86.7 & 113 & 56 & 84,8 & 66 & 146 & 87,4 & 167 & 8 & 66,7 & 12 & 134 & 84,8 & 158 & 20 & 95.2 & 21 \\
\hline Nào re-encape de agulhas & 90 & 77.6 & 116 & 51 & 80,9 & 63 & 131 & 78.4 & 167 & 10 & 83.3 & 12 & 120 & 75.9 & 158 & 20 & 95,2 & 21 \\
\hline $\begin{array}{l}\text { Lavagem das mãos após a realização dos } \\
\text { procedimentos }\end{array}$ & 86 & 40.0 & 215 & 43 & 40.9 & 105 & 120 & 39,2 & 306 & 9 & 64.3 & 14 & 117 & 41.0 & 285 & 12 & 34,3 & 35 \\
\hline
\end{tabular}

*numero total de procedimentos

**Convènios Privados/Pagamentos particulares 
Característica dos pacientes atendidos, no que diz respeito à forma de remuneração do hospital pelos serviços, se beneficiário do SUS ou de convênios privados/pagamentos particulares, não atua de forma estatisticamente significativa na adesão à prática da lavagem prévia das mãos à realização de procedimentos por parte dos profissionais. Verificamos, todavia, diferenças estatisticamente significativas no nível de $6 \%(p=0,06)$ para o uso de luvas. A prática, ainda que ocorrendo modestamente, mostrou-se mais freqüente para o atendimento de pacientes cuja fonte pagadora é governamental (SUS). Cabe a observação, entretanto, que o tipo de procedimento para os quais mais se observaram o emprego de luvas (punção por intra cath e com agulhas tipo gelco), também foi mais utilizado em pacientes do SUS, dado este que de certa maneira justifica, pelo menos em parte, os resultados observados.

Não constatamos, em contrapartida, diferenças estatisticamente significativas para a característica em foco, quando se atém ao descarte imediato das agulhas. Mas as práticas, se distinguem no nível de $5 \%(p=0,05)$ de significância, quando se trata do reencape de agulhas. Observamos maior correção nos procedimentos após atendimento de paciente de convênios privados do que usuários do Sistema Único de Saúde (SUS). Vale ressaltar que verificamos maior freqüência de punções com escalpe nos pacientes de convênios privados e para esse tipo de apetrecho, o emprego do re-encape mostrouse também, no geral, menor. Por sua vez, a lavagem das mãos após punções não ocorre, de forma distinta quando do atendimento de um ou outro grupo aqui considerado.

Já a idade do paciente afigura-se, em contrapartida, como elemento que distingue de forma estatisticamente significante, ao nível de $0,1 \%(p=0,001)$, os eventos de lavagem das mãos antes dos procedimentos de punções observados no escopo deste trabalho, sendo a aderência à técnica inversamente proporcional à faixa etária, conforme tabela 13.

Acontecimento similar ocorre com o uso de luvas por parte dos profissionais para a realização das práticas. Observemos porém que ocorre uma inversão em termos percentuais, quanto à adesão à prática para as faixas etárias superiores à 20 anos, 
mostrando-se o uso de EPI com freqüência proporcional à idade do usuário dos serviços.

O descarte imediato de agulhas também se apresenta de forma diferente estatisticamente, no nivel de $1,5 \% \quad(p=0,015)$, quando se tem em conta os procedimentos executados de acordo com as faixas etárias dos pacientes. Contrariamente as técnicas anteriormente apresentadas (lavagem das mãos e uso de luvas), obsẹva-se haver uma tendência para a adesão à prática correta diretamente proporcional às idades dos pacientes. A mesma tendência de igual modo, com distinções estatisticamente significantes, ao nível de $0,9 \%(p=0,009)$, é observada para a prática do não re-encape de agulhas.

A exemplo da lavagem prévia das mãos, também a lavagem pós realização dos procedimentos mostra-se mais freqüente quando se trata de atender às crianças do que os jovens e adultos, diferenças estatisticamente significativas ao nível de 1,2\% $p=0,012)$. 
Tabela 13 - Procedimentos realizados por profissionais de hospitais da cidade de Itabuna envolvendo o emprego de medidas de autoproteção de acordo com a faixa etária dos pacientes. Itabuna-Ba. 2002.

\begin{tabular}{|c|c|c|c|c|c|c|c|c|c|c|c|c|c|c|c|}
\hline \multirow{3}{*}{ Medidas de auto proteção } & \multicolumn{3}{|c|}{ Menor que um ano } & \multicolumn{3}{|c|}{ De um a 12 anos } & \multicolumn{3}{|c|}{$\begin{array}{l}\text { Maior que } 12 \text { e menor } \\
\text { que } 20 \text { anos }\end{array}$} & \multicolumn{3}{|c|}{ De 20 a 60 anos } & \multicolumn{3}{|c|}{ Maior que 60 anos } \\
\hline & \multicolumn{2}{|c|}{ Sim } & \multirow{2}{*}{$\begin{array}{c}\text { Total } \\
*\end{array}$} & \multicolumn{2}{|c|}{$\operatorname{Sim}$} & \multirow{2}{*}{$\begin{array}{c}\text { Total } \\
*\end{array}$} & \multicolumn{2}{|c|}{ Sim } & \multirow{2}{*}{$\begin{array}{c}\text { Total } \\
*\end{array}$} & \multicolumn{2}{|c|}{ Sim } & \multirow{2}{*}{$\begin{array}{c}\text { Total } \\
*\end{array}$} & \multicolumn{2}{|c|}{$\operatorname{Sim}$} & \multirow{2}{*}{$\begin{array}{c}\text { Total } \\
*\end{array}$} \\
\hline & N. ${ }^{\circ}$ & $\%$ & & N. ${ }^{\circ}$ & $\%$ & & N..$^{\circ}$ & $\%$ & & $N^{\circ}$ & $\%$ & & N. ${ }^{0}$ & $\%$ & \\
\hline $\begin{array}{l}\text { Lavagem das mãos antes da realização dos } \\
\text { procedimentos }\end{array}$ & 28 & 70 & 40 & 14 & 60,9 & 23 & 12 & 44.4 & 27 & 63 & 37.9 & 166 & 30 & 36.1 & 83 \\
\hline Uso das luvas para a realização dos procedimentos & 19 & 47,5 & 40 & 8 & 34,8 & 23 & 5 & 18.5 & 27 & 18 & 10,8 & 166 & 12 & 14.4 & 83 \\
\hline Descarte imediato de agulhas utilizadas & 16 & 76.2 & 21 & 6 & 54,5 & 11 & 9 & 90 & 10 & 85 & 91,4 & 93 & 38 & 86,4 & 44 \\
\hline Nào re-encape de agulhas & 13 & 61.9 & 21 & 6 & 50 & 12 & 7 & 70 & 10 & 74 & 82.2 & 90 & 41 & 89.1 & 46 \\
\hline $\begin{array}{l}\text { Lavagem das mãos após a realização dos } \\
\text { procedimentos }\end{array}$ & 22 & 59.4 & 37 & 13 & 59.1 & 22 & 6 & 23.1 & 26 & 57 & 36.5 & 156 & 31 & 39.2 & 79 \\
\hline
\end{tabular}

*número total de procedimentos 


\section{DISCUSSÃO - ESTUDO DO PROCESSO - ADERÊNCIA ÀS PRÁTICAS DE AUTO-PROTEÇÃO NAS VENIPUNÇÕES.}

Observar o modus operandi dos profissionais, debitadas todas as limitações inerentes ao tipo de estudo e também do corte transversal necessário para se dar conta de uma compreensão mínima do "como" os profissionais incorporam ou não ao seu dia-adia preconizações, permite, em alguma medida, visualizar o "entremeio" entre as questões estruturais das instituições hospitalares exploradas na primeira parte deste estudo e os discursos dos profissionais da saúde engajados nestas mesmas instituições, acerca de temas da biossegurança, conforme será visto adiante.

Dessa forma, o tema lavagem das mãos antes da realização de procedimentos com os pacientes, muito embora medida mais para proteção dos próprios usuários dos serviços do que propriamente forma de auto-proteção dos profissionais da saúde, não pode deixar de ser discutido face à sua importância enquanto dimensionamento da incorporação de ações protetoras contra infecções em hospitais.

Assim, observamos, neste trabalho, que a prática da lavagem das mãos antes da realização dos procedimentos aqui analisados, as venipunções, não se faz de forma universal. Essa constatação, entretanto, não se constitui em prerrogativa deste estudo.

A lavagem das mãos embora veementemente difundida há dezenas de anos como imprescindível à prevenção de infecções em hospitais quase nunca se apresenta com os níveis de adesões desejáveis conforme documentam diversos trabalhos.(PITTET et al 1999; HARRIS et al 2000).

Neste estudo, detectamos que os procedimentos de punções venosas foram precedidas pela higienização das mãos em $43,4 \%$ das oportunidades. A título de estabelecermos um paralelo com a literatura, cabe a observação de que trabalhos têm demonstrado que as taxas de aderência à lavagem das mãos para o desenvolvimento de cuidados com pacientes apresentam-se quase sempre em níveis menores que $50 \%$ 
(HARRIS et al. 2000). Todavia, essas pesquisas, em geral, tratam da aderência à prática nos cuidados com os pacientes, sem, contudo, focar uma técnica específica. $\dot{E}$ possível que, se ativessem à pratica de punções venosas, os resultados fossem melhores.

Do exposto, importa ressaltarmos que os resultados aqui encontrados, embora dentro do que se pode chamar de "esperado", ou pelo menos nos limites do que a literatura tem trazido, mostram-se, ainda assim, pouco alvissareiros.

Observamos ainda no presente estudo, distinções estatisticamente significativas entre os três hospitais nos quais se desenvolveu o trabalho e os maiores percentuais de aderência à prática foram observados em hospital no qual nos ativemos a unidades destinadas ao atendimento de crianças.

Detectamos também, que a lavagem prévia das mãos aos procedimentos ora em tela atinge percentual praticamente ideal no berçário. Nos prontos socorros todos nos quais empreendemos as observações, verificamos aderências de 41,8\%. Resultados esses, melhores do que aqueles detectados nas unidades de internação, com $33,7 \%$.

Os resultados aqui encontrados possivelmente podem ser explicados, em parte, pelas peculiaridades dessas unidades de atendimento nos hospitais pesquisados. Isso porque o berçário destina-se prioritariamente ao tratamento de recém nascidos de alto risco, foi recentemente equipado, submetido a reformas estruturais e o pessoal treinado especificamente para a lavagem das mãos. Nenhum profissional e nem mesmo os visitantes, são autorizados a adentrar nas instalações da unidade sem adotar o respectivo cuidado. A própria infra-estrutura do setor configura-se como elemento facilitador à prática em questão, visto que se dispõe, logo na entrada do alojamento das crianças, pia com saboneteira sempre provida, pelo menos nos períodos nos quais se procederam as observações afetas à este estudo, de sabão liquido e papel toalha.

Quando nos atemos aos prontos socorros e unidades de internação das instituições hospitalares nas quais empreendemos o estudo, detectamos, por outro lado, dinâmicas particulares. Nos primeiros setores, a infra-estrutura fisica, ainda que 
absolutamente não ideal, aproxima-se mais do razoável do que as unidades de internação. Em dois dos prontos socorros, um destinado ao atendimento de adultos e o outro ao de crianças e gestantes, estão presentes pias nos postos de enfermagem. bem como nas próprias salas de atendimento com recipientes apropriados para sabão liquido (embora alguns periodos desprovidos de conteúdo) e papel toalha (também alguns periodos sem a devida reposição). Num terceiro pronto socorro, embora inexistam pias nos lugares destinados ao atendimento, o posto de enfermagem é bastante próximo, à exceção do local onde ficam os pacientes em observação no aguardo de internação.

Em contrapartida, as unidades de internamento de pacientes caracterizam-se, por uma infra-estrutura ainda mais precária, no tocante à disponibilidade de pias. Nos três hospitais pesquisados, essas estão localizadas nos postos de enfermagem, que por sua vez ficam a razoável distância dos quartos dos pacientes. Uma ou outra enfermaria até dispõe de pias, mas essas são utilizadas com pouca freqüência. Em nenhum dos dias em que empreendermos as observações, existiam nessas pias, sabões e meios de se secarem as mãos.

Observemos que os dados aqui levantados, no que diz respeito à aderência à lavagem das mãos em diferentes setores hospitalares, coadunam com os resultados de FREEMANN (1993). Esse autor constata que a adesão à lavagem das mãos é maior em setores fechados, onde pias e produtos utilizados para a respectiva higienização são mais acessiveis, do que nos setores abertos nos quais o acesso a esses mesmos elementos se faz mais complexo.

No que se refere ao dimensionamento de pessoal, pudemos observar que as escalas de auxiliares e técnicos de enfermagem dos quais mais procedimentos foram observados neste estudo, apresentam-se pouco mais elastecidas nos prontos socorros, se comparadas àquelas direcionadas ao internamento de pacientes, com um quantitativo médio de funcionários de quatro componentes para um atendimento de cerca de cinqüenta pacientes por período. Nas unidades de internação o número de pacientes por funcionário fica em torno de oito, no caso dos adultos e seis na unidade pediátrica. Cabe complementarmente a observação de que no caso dos atendimentos 
nos prontos socorros alguns circunscrevem-se apenas a consultas médicas enquanto nas unidades de internamento a relação enfermagem/paciente mencionada prevê a administração de cuidados integrais a todos os pacientes. Esses mesmos pacientes quase todos, altamente dependentes.

As características dos pacientes atendidos nos prontos socorros estudados mostramse peculiares. Não obstante, logicamente, o atendimento de emergências, proporção não desprezivel de atenções volta-se para problemas que não são classificados propriamente como emergenciais, como cefaléias, mal estares gástricos, indisposições relacionadas à dengue, dentre outros de naturezas parecidas.

PITTET et al (1999) detectaram em respeito a setores de atendimento de pacientes, melhores adesões à prática da lavagem das mãos em unidades de internação do que em Centro de Terapia Intensiva. Verificaram ainda que a percepção de muito trabalho a desenvolver reduz substancialmente a freqüência na aderência à prática em questão, o que de certa forma respalda nossa tese de que as especificidades das unidades de internamento observadas neste presente estudo, em respeito à carga de trabalho, influenciam na aderência ao cuidado em foco.

Em respeito aos resultados que demonstram maiores adesões à lavagem das mãos pelos enfermeiros, embora ressaltando a modéstia amostral de nossos achados, podemos supor que em parte elas se devam à maior conscientização dos profissionais acerca da importância do cuidado, mas também em parte ao processo de trabalho diferenciado se comparado aos auxiliares e técnicos de enfermagem. Ou seja, nos hospitais estudados, a realização de procedimentos por parte dos enfermeiros é mais ocasional ,posto que suas atividades direcionam- se mais às atividades burocráticas. Assim é de se esperar que ao desenvolver uma ação mais esporádica se empregue as medidas preconizadas.

De igual modo ao aqui apresentado, se bem que comparações aprofundadas não se permitam, vez que as proporções de eventos observados são expressivamente diferentes, bem como a própria tipologia destes mesmos eventos, podemos citar novamente PITTET et al. (1999), que também detectaram maior aderência à 
lavagem das mãos por parte dos enfermeiros a despeito de médicos e outros trabalhadores de enfermagem.

Consideramos que seja possivel que a adesão à lavagem das mãos previamente aos procedimentos de venipunção, desenvolvidos em caráter de rotina e por profissionais com tempo intermediário de formação, a despeito dos recém formados, ocorra em função de um maior sentimento de segurança.

Essa inferência respalda-se nas observações de GODIN et al. (2000), que referem, de posse de resultados de estudo com enfermeiros também acerca de venipunção, que profissionais que não expressam autoconfiança em suas habilidades apresentam dificuldades em aderir às precauções universais/padrão.

Por seu turno, conhecer o diagnóstico do paciente, pode indicar que o profissional teve um tempo mínimo de reflexão antes de desencadear os cuidados com o paciente, tempo esse que the permitiu inclusive lavar as mãos antes da realização do procedimento. Entretanto, isso é mais válido para os atendimentos realizados nos prontos socorros, haja vista que a possibilidade de se conhecer o diagnóstico dos pacientes em unidades de internamento é reconhecidamente maior, posta a maior frequêencia de contato.

No que diz respeito à menor adesão aos procedimentos de auto-proteção por profissionais formados há mais tempo, não parece haver explicação plausivel, muito embora diversos trabalhos confirmem essa constatação.

Em contrapartida, os resultados aqui verificados no referente à lavagem das mãos por parte dos profissionais quando da execução de punções venosas, levando-se em conta a idade dos pacientes, vêm ao encontro também dos dados de PITTET et al. (1999), que também observaram maior aderência à lavagem das mãos em unidades pediátricas, a despeito dos serviços de atendimento de adultos.

Observemos que os índices de aderência à prática de lavagem das mãos após a realização dos procedimentos seguem, por seu turno, praticamente a mesma lógica observada para a higienização prévia aos procedimentos. 
O emprego da referida medida de auto-proteção não ocorre, por outro lado, com distinções estatisticamente significativas, quando executadas as punções pelas diferentes categorias profissionais, mas há uma tendência de que os profissionais do sexo feminino apresentem-se mais aderentes à prática, assim como dentre os com tempo de formado entre cinco e dez anos, se comparados àqueles com menor e maior tempo ao período citado.

Interessante notarmos que a adesão à prática em foco mostrou-se mais freqüente nas situações cujas punções foram consideradas como emergenciais, do que nas de rotina, diferentemente do observado para a lavagem das mãos antes da realização dos procedimentos.

Talvez a maior gravidade da situação explique uma maior preocupação com a autoproteção posto que desperte mais nos profissionais a consciência acerca dos riscos.

Porém, é oportuno darmos relevo que não foram encontrados trabalhos de sorte a embasar ou refutar essa suposição, que tratem da lavagem das mãos especificamente após a realização de procedimentos e que intentem dimensionar o sentimento de auto-proteção por parte dos profissionais, conferido pela prática em questão.

Somente como ilustrativo do cenário da aderência à lavagem das mãos pós procedimentos de venipunções, cumpre-nos citar ROURKE e READ (2001), que, em pesquisa com profissionais atuantes em hospital do Reino Unido, verificaram que apenas $42,0 \%$ deles disseram proceder à lavagem prévia e após a realização de punções e 45,0\% afirmaram lavar as mãos somente após a realização do procedimento.

Convém ressaltarmos que a adesão média de lavagem das mãos após punções venosas encontrada no presente estudo foi de $40,3 \%$, dado esse que, cotejado com os do estudo supracitado de alguma forma, guardam coerência.

Analisando a aderência ao uso de luvas para a realização de punções, observamos prática confluente com a lavagem das mãos na distinção dos três hospitais investigados. É também no hospital que procedemos observação nas atividades afetas 
ao trato com crianças que o uso do equipamento de proteção individual em foco é mais utilizado, embora o emprego do dispositivo possa ser considerado, no geral, baixo.

A constatação de que o uso de luva se faz mais presente nos cuidados com crianças pode levar a crer que o dispositivo seja utilizado, pelo menos para essa clientela, com o intuito maior de proteção do paciente do que propriamente enquanto equipamento de auto-proteção para o profissional.

Cumpre-nos enfatizar que a aderência ao uso de luvas para as técnicas de punções se faz bastante menor ( $9,3 \%$ das oportunidades) nos prontos socorros, do que nas unidades de internamento, diferentemente dos resultados encontrados para a lavagem das mãos antes e após a realização dos procedimentos.

Uma possibilidade de explicação para tal fenômeno talvez seja, mais uma vez, as diferentes dinâmicas desses dois tipos de unidades. No caso dos prontos socorros, o número de punções é maior do que nas unidades de internação. Acresce-se o fato de que, em geral, um ou dois profissionais, no caso dos auxiliares e técnicos de enfermagem, ficam responsáveis pela medicação dos pacientes e, consequentemente, pela maioria dos procedimentos afetos às punções venosas. Esses dois fatores remetem à um quadro de um sem número de procedimentos realizados pelo mesmo profissional. Isso talvez o afaste da prática de a cada procedimento calçar luvas. Observamos também que número muito expressivo de punções realizadas nos prontos socorros são executadas com agulhas tipo escalpe, para as quais o emprego de luvas, pudemos observar, constitui-se praticamente nulo.

Notemos, por outro lado, que nas unidades de internação, o número de punções é reconhecidamente menor, sendo realizado. salvo exceções, de forma menos seriada que nos prontos socorros.

Também não podemos deixar de citar que, embora tenhamos notado a presença de estoque de luvas descartáveis nas unidades pesquisadas durante os períodos em que foram empreendidas as observações, isso não quer dizer que estas seriam suficientes e repostas à contento, na hipótese de todos virem a usar os EPIs, para todos os 
procedimentos para os quais são indicadas. Além disso, não podemos deixar de levantar a hipótese da existência de um "acordo" implícito entre os profissionais e o hospital, relativa à economia no uso dos dispositivos em foco.

De acordo com NAING et al. (2001), problemas administrativos como estoques irregulares de luvas foi mencionado por $46 \%$ dos sujeitos de estudo empreendido pelos autores, em hospital tailandês, como elemento restritivo à adesão ao apetrecho. Os pesquisadores observaram também $44 \%$ de referência à indisponibilidade dos EPIs nas unidades de emergência.

Nossos dados, acerca do emprego de luvas para a execução de punções, de acordo com os diferentes tipos de unidades nos hospitais, são coerentes com os resultados de ADEGBOYE et al. (1997), que verificaram, em trabalho empreendido em complexo hospitalar de 500 leitos, localizado no sudeste da Nigéria, que as unidades ambulatoriais e de emergência apresentavam-se com as terceiras maiores percentagens de trabalhadores que referiam uso esporádico de luvas.

Ainda quanto à literatura que trata do emprego de luvas aqui discutido cabe-nos citar KACZAMAREK et al. (1991), que afirmam com base em estudo desenvolvido em 26 instituições hospitalares americanas, que o seu uso , embora importante não se demonstra universal. Os autores verificaram, por exemplo, aderência ao uso de luvas em $92,3 \%$ das punções arteriais, $77,6 \%$ das oportunidades de inserção/manutenção de agulhas para a infusão de soros e em 70,6\% em inserções de cateteres venosos. Detectaram ainda que maiores aderências, em particular desses últimos procedimentos, ocorreram em localidades cujo número de atendimentos anuais de pacientes com AIDS constituía-se maior.

Confrontando com os dados desses autores, notamos que a aderência ao uso de luvas aqui encontrado, no geral, $17,4 \%$ mostra-se substancialmente menor que os verificados por eles, na realidade americana, há pelo menos dez anos atrás.

Ressaltamos ainda que, neste presente estudo, detectamos que o uso de luvas é mais contumaz em situações cuja punção se dá como de emergência $(53,3 \%)$, do que nas consideradas rotineiras $(15.7 \%)$, o que pode denotar uma vez mais preocupação dos 
profissionais com a auto-proteção quando do atendimento nas primeiras condições. Cumpre citarmos, todavia, que as situações de emergência demandam o emprego de punções mais reconhecidamente relacionadas ao uso de luvas, como a introdução de intra caths e a instalação de agulhas tipo gelco.

O tipo de procedimento empreendido possivelmente também explique as diferenças de adesão ao uso de EPI, quando comparadas as aderências dos profissionais ao uso de luvas segundo suas categorias. Apesar dos modestos números absolutos, $100 \%$ dos médicos usaram luvas para as punções que realizaram (dois intra caths e dois gelcos). Para os enfermeiros, a adesão ao uso de luvas foi de $33,3 \%$ e dos nove procedimentos observados, dois deles eram punções com gelco. Os auxiliares e técnicos de enfermagem, por seu turno, foram observados realizando a maior parte dos procedimentos, incluindo-se punções com escalpes para os quais o uso de luvas mostrou-se baixo $(10,5 \%)$.

Todavia, em contraponto aos resultados aqui verificados, cumpre-nos referenciar YENTIS et al (1993) citado por GODIN et al (1998, p 413), que observaram que médicos raramente ou nunca calçam luvas durante a inserção de cateteres venosos.

ROURKE \& READ (2001), por seu turno, em trabalho desenvolvido em hospital universitário de 1.200 leitos do Reino Unido, com a aplicação de questionário a médicos, enfermeiros, estudantes de medicina e flebotomistas, verificaram que $48 \%$ dos sujeitos quando argüidos sobre o uso de luvas para punções venosas, afirmam empregar sempre o EPI e $27 \%$ não as utilizavam ou as calçavam apenas ocasionalmente.

O'ROURK et al. (2000), em outro estudo, chegou a percentual de $39 \%$ de anestesistas de hospital irlandês, que sempre empregavam luvas para a inserção de cateteres venosos.

Acerca de enfermeiros NAING et al. (2001), detectaram aderência ao uso de luvas em procedimentos de punções venosas para coleta de sangue de $27 \%$. Verificaram ademais indicativo de utilização seletiva do EPI, mais relacionada ao trato com 
pacientes considerados como de grupos de risco ou casos suspeitos de AIDS, do que com os demais usuários do serviço hospitalar.

Diferentemente, nossos resultados indicam que conhecer ou não o diagnóstico do paciente não se mostra quesito a diferenciar a atitude dos profissionais relativa à adesão ao uso de luvas para a execução de punções. Tal dado pode ser visto como elemento positivo, na medida em que, de algum modo, desvela que o profissional parece não fazer um juízo de valor concernente ao diagnóstico do paciente para a decisão de usar luvas, o que vem ao encontro das preconizações das precauções universais/padrão.Não podemos deixar de frisar, entretanto, a baixa aderência, no geral ao uso do EPI.

Há que se registrar, por outro lado, que não se observaram situações nas quais as punções fossem demandadas por pacientes sabidamente infectados por vírus de veiculação sangüínea. Desse modo, não podemos descartar a hipótese de que, se o usuário fosse reconhecidamente portador de vírus dessa natureza, as atitudes dos profissionais em respeito ao uso de luvas pudessem ser diferentes.

No que diz respeito à preconização do descarte imediato de agulhas após a realização de punções, observamos percentuais de adesão relativamente próximos ao que poderia se considerar adequados. Há, entretanto, diferenciações nas adesões entre os hospitais e, nesse caso, a instituição mais direcionada ao atendimento preponderante de crianças se afasta mais do ideal.

Explicação plausivel para o evento talvez seja o fato de que ao se lidar com crianças se tenha maiores dificuldades de uma vez findo o procedimento se deslocar para o descarte do material. Isso porque pudemos perceber que, ao término das punções de infantes, os auxiliares e técnicos de enfermagem, em particular, encadeiam, com relativa freqüência, outros cuidados com esses pacientes ou com outros. Também não podemos deixar de indicar como plausivel a possibilidade de que a noção de risco se faça menor quando do atendimento de crianças.

Colabora com essa prática de não se descartar imediatamente os pérfuro-cortantes o fato de os recipientes destinados ao seu acondicionamento localizarem-se fora dos 
ambientes nos quais são realizados os procedimentos, ou seja, estão sempre nos postos de enfermagem que, particularmente nos casos das enfermarias, distanciam-se razoavelmente entre si.

Conflui para a conformação deste quadro a constatação de que, quando comparados os descartes das agulhas nos diferentes setores dentro de cada hospital, há diferenças de adesão em todas as instituições, sendo as alas de internação as que apresentam os resultados mais modestos.

Em dois prontos socorros onde empreendemos as observações, os recipientes destinados ao descarte de pérfuro-cortantes estavam presentes no posto de enfermagem e também nas respectivas salas de atendimento. Em um deles, a existência dos recipientes restringia-se ao posto de enfermagem, mas o distanciamento dos locais onde se procediam os cuidados com os pacientes era visivelmente menor do que os observados nas enfermarias de internamento. No berçário e unidade de atendimento especial (UTE), o recipiente também encontravase somente no posto de enfermagem, mas tratam-se essas unidades de setores fechados e de menor dimensionamento físico.

Cabe o adendo de que consideramos como existente a presença de qualquer recipiente com fim específico de descarte de pérfuro-cortante nos hospitais. Nem todas as unidades hospitalares dispunham, contudo, de caixas tipo IPT conforme o recomendado, já outras as dispunham somente em alguns plantões. Em boa parte das observações, os recipientes destinados ao fim em discussão eram constituidos por garrafas plásticas, frascos de desinfetantes, dentre outros. Essa situação foi mais freqüentemente observada nas unidades de internamento de pacientes do que nos prontos socorros e unidades fechadas, a exemplo do berçário e UTE.

Ainda sobre o descarte imediato de agulhas pós punção, verificamos que essas são mais prontamente descartadas, como até esperado, em situações de rotina do que de urgência. Por outro lado, quando nos detemos sobre o aspecto do descarte imediato das agulhas pós realização de punções segundo as categorias profissionais, detectamos, embora levando-se em conta os modestos números, que os enfermeiros 
apresentam-se mais aderentes à prática do que os auxiliares e técnicos de enfermagem.

Isso pode ser explicado, em parte, pela conscientização dos profissionais quanto a medidas de biossegurança, mas também pela especificidade de seu processo de trabalho, conforme já citado. Os enfermeiros, nos hospitais estudados, envolvem-se muito mais com atividades administrativas do que propriamente assistenciais, sendo assim, realizam menos procedimentos invasivos nos pacientes. Desta forma, quando os executam, possivelmente têm melhores condições de seguir as preconizações, posto que parecem realizar procedimentos em série com menor freqüência.

Os médicos, por outro lado, apresentaram baixa adesão à prática de descarte imediato de agulhas, embora não se possa esquecer, de igual modo, o modestíssimo número de procedimentos observados levados à efeito por esses profissionais. Nesse caso, a baixa aderência ao que se preconiza, explica-se pela rotina de trabalho instituida. Quando esses profissionais executam práticas invasivas, a exemplo das punções venosas em geral, os auxiliares e técnicos de enfermagem ou mesmo os enfermeiros ficam responsáveis pela organização dos materiais, seja no pré ou no pós punção, e os médicos, especificamente nas unidades em apreço, ficam desincumbidos de descartar imediatamente as agulhas utilizadas.

No tocante à prática de não re-encapar agulhas, essa vem sendo bastante debatida e investigada, particularmente a partir de meados da década de noventa, quando as preocupações com os acidentes pérfuro-cortantes enquanto mecanismos de contaminação de profissionais, com vírus de veiculação sangüinea (AIDS, hepatites $\mathrm{B}$ e C, particularmente), começam a tomar corpo. Até então, a técnica rotineira era a de, uma vez findos os procedimentos com agulhas, encadear o seu imediato reencape antes de se descartar ou encaminhar os materiais para re-esterilização.

Os resultados que aqui detectamos demonstram que, em certa medida. as preconizações mais atuais já se fazem substantivamente presentes na prática, ainda que não universalmente acatadas, posta a adesão média encontrada de $78,33 \%$, com 
diferenças estatisticamente significativas quando comparados os três hospitais nos quais se empreendeu o estudo.

Interessante notarmos que ainda concernente a esse aspecto, o hospital $\mathrm{T}$, no qual nos ativemos às unidades pediátricas foi o que apresentou os resultados mais modestos de adesão $(60,6 \%)$.

Quando tomamos as diferentes unidades dos hospitais, verificamos que o berçário, o qual para quase todas as demais medidas sempre apresentara as melhores taxas de aderências aos itens aqui observados, mostrou-se para a técnica em pauta, abaixo da média de todas as unidades, aproximando-se mais dos setores de internamento de pacientes $(60,0 \%)$, setores esses que para os demais itens sempre se apresentaram mais deficitários.

Esses resultados podem estar relacionados à menor perspectiva de risco quando do atendimento de crianças. Por outro lado, salvo o percentual de 100\% de adesão verificado na UTE, mas que não tem confiável valor estatístico face à modéstia amostral, é nos prontos socorros que apresentam-se os resultados mais alvissareiros ( $87,2 \%$ de aderência à prática de não re-encapar agulhas após uso). É possível, portanto, que os profissionais atuantes nos prontos socorros estejam mais conscientizados da importância da recomendação em apreço.

Também é provável que a estruturação física desses últimos setores, pelo menos quando comparados às alas de internamento, colabore com a prática em questão. Mister lembrar que nos prontos socorros, por conta de suas estruturações físicas, os recipientes coletores de agulhas encontram-se mais próximos às áreas de realização dos procedimentos aqui estudados. Isso pode, consequentemente, atuar como estímulo ao descarte imediato das agulhas sem prévio re-encape. Não podemos negar, todavia, que o tipo de agulha que observamos uso preponderante nos prontos socorros do estudo, os escalpes, deva ter suas influências na maior adesão à técnica no setor em questão, por suas específicas características.

Em relação aos procedimentos realizados pelos profissionais subdivididos por categorias não observamos, por outro lado, diferenciações estatisticamente 
significativas para a preconização sob análise, (ainda que percentuais mais modestos, $77,7 \%$ de aderência sejam detectados para os auxiliares e técnicos de enfermagem, quando comparados com os $100 \%$ observados para os médicos e enfermeiros), o que indica que a importância de não se re-encapar agulhas já é item de conhecimento das diferentes categorias profissionais.

Outro ponto é que o tempo de formado desses mesmos profissionais não se mostrou elemento a diferenciar a aderência à prática preconizada, diferentemente de alguns estudos prévios que detectam tendência de os profissionais formados há mais tempo terem maiores dificuldades de adesão à prática, face ao fato de não terem sido treinados durante seus respectivos períodos de formação.

Em estudo de BECKER et al. (1990), por exemplo, desenvolvido em quatro hospitais de grande porte dos Estados Unidos, verificou que, a despeito da implementação de normas escritas acerca das precauções universais, quase um terço dos trabalhadores entrevistados, incluindo-se médicos, enfermeiros e auxiliares e técnicos de enfermagem, não discordavam que re-encapar agulhas conferiria auto-proteção, ao contrário do que a literatura indica. Dos entrevistados, $50 \%$ também acreditavam que re-encapar agulhas promoveria maior proteção para os próprios colegas e, por fim, $34 \%$ indicava preferir re-encapar as agulhas a descartá-las sem capas ainda que em recipientes específicos.

Chamou a atenção dos autores o fato que menos da metade dos profissionais discordassem que há que se re-encapar as agulhas no caso dessas serem utilizadas em pacientes com diagnóstico firmado para AIDS, sendo os médicos mais enfáticos em apresentar sua discordância.

Procedendo, à paralelo, inspeção dos recipientes destinados ao descarte de materiais pérfuro-cortantes, puderam constatar que a percentagem de agulhas re-encapadas foi sempre maior que $25 \%$ e em boa parte dos serviços analisados o re-encape excedeuse a $50 \%$. Perceberam ainda que a realidade apresentava-se melhor em um dos hospitais campo de pesquisa, que havia desenvolvido previamente ao 
empreendimento do estudo, uma intensiva intervenção educacional na instituição, relativa ao tema em foco.

WILLIAMS et al. (1994), por seu turno, com o objetivo de dimensionar a aderência às práticas de não re-encape de agulhas por parte de profissionais atuantes em instituição hospitalar, verificaram que os pesquisados relatavam re-encape de agulhas em percentagens que variavam de $11 \%$ a $57 \%$ após os procedimentos de injeção intra-muscular, introdução de cateteres venosos, retirada de sangue de artérias e veias e administração de medicamentos endovenosamente.

HENRY et al. (1992), em estudo observacional, detectou 50\% de re-encape de agulhas em unidade de emergência de hospital universitário e $5 \%$ de descarte de agulhas não re-encapadas em locais inapropriados, dentre eles o lixo comum.

Os mesmos autores repetiram o mesmo tipo de estudo em 1994, em dois hospitais comunitários, verificando resultados pouco mais animadores para o re-encape, mas distante do ideal. Observaram também que 6,2\% das agulhas desprotegidas eram deixadas próximas ao leito dos pacientes ou desprezadas de igual modo ao verificado no estudo anterior, em lixo comum (HENRY et al. 1994).

Pesquisa mais recente de O'ROURK et al. (2000), com anestesiologistas atuantes em hospitais da Irlanda, verificaram que $56 \%$ da amostra de 105 respondentes às questões levantadas, referiram re-encapar algumas vezes agulhas utilizadas durante seu exercício profissional.

Estudo nacional de BREVIDELLI (1997), levado a efeito em hospital universitário paulista, demonstra $46 \%$ de acidentes com agulhas, relacionados a práticas inapropriadas de manipulação. Por descarte em local inapropriado; dessas 13,1\% levando-se em conta somente a equipe de enfermagem, 10\% ao re-encape de agulhas e 1,3\% ao desconectar a agulha da seringa. No caso de outros profissionais (médicos, pessoal de limpeza, pessoal administrativo), 39,7\% por descarte dos pérfurocortantes em local indevido, 3,7\% ao re-encapar agulhas e 1,5\% ao desconectar as agulhas da seringa. 
Analisando adicionalmente os conteúdos dos recipientes destinados ao descarte de pérfuro-cortantes, BREVIDELLI verificou ainda $50 \%$ das agulhas re-encapadas. Por outro lado, procedendo à análise temporal de incidência de acidentes por materiais pérfuro-cortantes, embora considerando que a ocorrência relacionada à prática de reencapar agulhas se mantivesse, na opinião da autora, ainda alto, a pesquisadora detectou queda dos citados eventos entre os anos de 1992 e 1996, possivelmente relacionado à implementação em 1992 das normas relativas às precauções universais/padrão no hospital campo de sua pesquisa.

Ressaltemos que neste presente estudo detectamos índices, que podem ser considerados como razoáveis no que diz respeito à aderências ao descarte imediato de agulhas em recipientes destinados ao fim específico e não re-encape de agulhas o que indica que o conhecimento das preconizações já se faz presente nos serviços investigados.

Entretanto, na prática, presenciamos, situações que, não obstante o suposto esforço dos profissionais em se autoprotegerem, podem colocar a si próprios e a outros em risco. Situações dentre as quais cabe-nos destacar, conforme já citado, o uso de recipientes de descarte adaptados presentes cotidianamente em todas as unidades pesquisadas do hospital. Afora este aspecto cabe-nos citar a superlotação dos recipientes, também constante durante os períodos compreendidos pelo estudo. 


\section{AS PERCEPÇÕES DOS PROFISSIONAIS ACERCA DO CONTAMINAR-SE E PRESERVAR-SE}

Levando-se em conta o conceito de biossegurança enquanto conjunto de normas e procedimentos considerados seguros e adequados à manutenção da saúde, em atividades de risco de aquisição de doenças profissionais e também da compreensão da biossegurança antes que uma disciplina no sentido estrito mas como um campo de realização de práticas técnicas e sociais destinadas a conhecer e controlar os riscos que o trabalho em saúde pode aportar ao meio e à vida (TEIXEIRA e VALLE 1998), consideramos importante estudar, além de elementos estruturais e aspectos do processo de trabalho relacionados ao tema, conforme visto nos capítulos anteriores, as percepções acerca de temas afetos ao contaminar-se e preservar-se para os profissionais de saúde imersos no dia-a-dia da assistência.

Para nos aproximarmos desse intento, construímos, a partir dos depoimentos apresentados pelos profissionais às nossas indagações, os discursos do sujeito coletivo, conforme proposto por LEFÈVRE et al. (2000).

Para cada uma das indagações, emergiram, então, um ou vários discursos, na medida em que existem no imaginário social, um ou vários sentidos para um mesmo tema.

A tarefa de construção dos discursos não se constituiu, no entanto, em tarefa fácil, não pela complexidade mesma do método, mas pela necessidade de meticuloso cuidado de, ao compô-los, não desfigurar sentimentos, minar conteúdos e, consequientemente, sentidos. Sentido enquanto elaboração social, por meio do qual as pessoas - na dinâmica das relações sociais historicamente datadas e culturalmente localizadas - constroem os termos a partir dos quais compreendem e lidam com as situações e fenômenos à sua volta (SPINK e MEDRADO 2000). 


\subsection{Sobre o risco de contaminar-se/contagiar-se}

Uma aproximação das representações sociais dos sujeitos da pesquisa, sobre o contaminar-se/preservar-se passa, necessariamente, pela busca de seu entendimento acerca de envolvimento ou não de riscos de contaminação e contágio pessoal nas atividades laborais que desenvolvem nos hospitais. Risco compreendido como a possibilidade de ocorrência de um resultado desfavorável, de um dano ou de um fenômeno inadequado (BARBOSA 1990).

Assim, para uma primeira questão norteadora, qual seja, "Suas atividades de rotina, no hospital, envolvem, de algum modo, algum risco de contaminação/contágio pessoal", praticamente todos os discursos produzidos mostram-se afirmativos, ainda que convirjam para direções diferentes. As idéias centrais captadas das falas dos profissionais médicos, por exemplo, são as abaixo agrupadas.

Quadro Síntese - Suas atividades de rotina envolvem, de algum modo, algum risco de contaminação ou contágio pessoal? ( Profissionais médicos)

Idéias Centrais

\begin{tabular}{|c|c|c|c|}
\hline $\begin{array}{l}\text { O risco decorrente do } \\
\text { ambiente (manipulação } \\
\text { de sangue, secreções, } \\
\text { materiais pérfuro- } \\
\text { cortantes e a flora } \\
\text { hospitalar). }\end{array}$ & $\begin{array}{l}\text { O risco decorrente do } \\
\text { contato com pacientes } \\
\text { desconhecidos e } \\
\text { portadores de doenças } \\
\text { infecto- contagiosas. }\end{array}$ & $\begin{array}{l}\text { O risco decorrente } \\
\text { da negligência na } \\
\text { auto-proteção. }\end{array}$ & $\begin{array}{l}\text { O risco dependente } \\
\text { das condições } \\
\text { imunológicas dos } \\
\text { profissionais. }\end{array}$ \\
\hline
\end{tabular}


Da idéia central, o risco decorrente do ambiente, para a qual se dirigem boa parte das falas dos profissionais médicos, abstraiu-se o Discurso do Sujeito Coletivo (DSC) abaixo.

\section{DSC dos médicos}

O risco é direto, o risco é diuturno. Realmente corremos muito risco de infecção. Trabalha-se com material cortante, com bisturi. Muitas vezes, você entra em contato com osso. As vezes o osso, com a parte aguda, fura a luva. Isso é bem freqüente. Em algumas oportunidades, de vasos que são rompidos, saem esguichos de sangue para o rosto da gente. Isso é comum acontecer. Cair no rosto, na testa, na boca. Acontece demais. Na emergência, depara-se com pacientes com sangramentos por diversas causas, por tiro, por facada. Na sala de parto, entra-se em contato com muito sangue e muita secreção. Tem as manobras de ressuscitação, entubação e ainda pacientes com ferimentos infectados, fora o próprio meio hospitalar. Os staphylococcus super resistentes, as pseudomonas, as klebsiellas, a escherichia coli, que são bactérias realmente de ambiente hospitalar, já resistentes, por causa do uso dos antibióticos e manipulação inadequada dos pacientes.

Entrevistados $1,2,3,4,6,7,8,9,10,11,12,13,14,17,20$.

Observamos que trata-se de falas enfáticas, sem nenhuma dúvida, "o risco é direto, o risco é diuturno". "Realmente corremos muito risco de infecção".

O discurso se abre, depois, para uma explicação desse risco. Risco todo depositado no ambiente insalubre do hospital e nos procedimentos e técnicas nele desenvolvidos, o material cortante, o bisturi, o osso, o sangue que jorra nos rostos, a abundância das secreções emitidas pelos pacientes acolhidos nas emergências, nas salas de parto, nas cirurgias.

Depreendemos, pois, que os profissionais pensam no risco que estará no sangue, nas secreções, no ambiente pródigo de bactérias super resistentes, algumas delas resultado do próprio ato médico - o uso muitas vezes indiscriminado e abusivo dos antibióticos. 
Num segundo discurso, revela-se o risco decorrente do contato com pacientes desconhecidos e portadores de doenças infecto-contagiosas.

\section{DSC dos médicos}

Lida-se com pacientes que não se sabe a origem. Pacientes de outras cidades. Pacientes com doenças sexualmente transmissíveis. Pacientes com meningite, tuberculose, hepatite. Pacientes com AIDS. E nem sempre se sabe que esses pacientes são portadores dessas afeç̧ões. Trabalha-se com pacientes de risco em potencial. Na maioria das vezes não se sabe, não se conhece muito bem, a história dos pacientes que chegam, às vezes, sem acompanhantes, sem uma pessoa da familia. As vezes fica-se um bom tempo sem ter qualquer informação sobre o paciente. Quando um paciente quebra uma perna, você não sabe se ele tem tuberculose, se ele tem sifilis, se ele tem AIDS, se ele tem hepatite. Você vai operar.

Entrevistados 2,4,8,14,15,19

Denota-se, desse segundo discurso, a preocupação com o desconhecido. O paciente que não se sabe a origem e que, portanto, não se sabe o que tem. "São pacientes de risco em potencial", pairando, então, dúvidas sobre até que ponto esses não poderiam se constituir em carreadores de microorganismos e de doenças - meningite, tuberculose e, principalmente, AIDS.

Esse discurso tem confluência com o que refere CZERESNIA (1997), para quem a epidemia da AIDS como um novo acontecimento epidêmico atualizou, no final do século $\mathrm{XX}$, a vivência trágica das epidemias, evidenciando como a vida invade o conhecimento de forma incontrolável. Para a autora, a radicalidade da experiência dessa epidemia fez detonar processos subjetivos e arcaicos, reavivando no imaginário social, as imagens simbólicas da "peste". A AIDS, ao mesmo tempo em que foi representada como "doença transmissível", o foi também como "doença contagiosa". O contágio é uma das imagens mais fortes da idéia do outro como fonte de ameaça e perigo, suscitando um medo genérico em que o contato é percebido como possibilidade de agressão. 
A noção de contágio, continua a autora, está justamente relacionada à vivência do medo, exasperação, negação do outro, lembrando as atitudes antigas de populações ameaçadas pela peste, como as de fuga, expurgos e isolamento .

Não obstante essa apreensão de certa forma exacerbada, principalmente com relação à AIDS, conforme veremos com até mais ênfase em alguns discursos mais adiante, há que referirmos que de fato esse vírus, bem como os da hepatite $\mathrm{B}$ e $\mathrm{C}$, principalmente, constituem em problemática para os profissionais de saúde, particularmente aqueles que, conforme depreendemos dos próprios discursos, lidam com sangue e materiais pérfuro-cortantes.

Embora como referem diversos pesquisadores já citados no escopo desse trabalho, a preocupação com os riscos de aquisição de infecções, principalmente através do sangue, seja relativamente recente e desencadeado, como frisa CZERESNIA, pela AIDS, não se pode furtar de referir que o risco ocupacional atribuído a patógenos veiculados pelo sangue tem sido documentado como um dos piores problemas nos ambientes de saúde. Para exemplificar podemos ilustrar que nos Estados Unidos, aproximadamente 6.500 e 9.000 trabalhadores de saúde são expostos a fluídos corpóreos infecciosos durante o trabalho. Essas exposições resultam em pelo menos 200 mortes anuais por hepatite $B$ e os profissionais de saúde têm um risco dez vezes maior de exposição ao mesmo vírus do que a população em geral. (CORSER 1998). Tais dados justificam em alguma medida as apreensões dos profissionais médicos aqui entrevistados.

Todavia observamos que o risco de se adquirir o HIV constitui-se significativamente menor que o HBV. O espectro de doença fatal e a imagem de doença incurável, envolta de mistério, conforme veremos adiante nas falas dos entrevistados, contribuem, contudo, para a maior importância atribuída à AIDS no cenário hospitalar e a sua expressão mais contundente nos discursos aqui apreendidos.

Não podemos deixar de lembrar também para ilustrar o cenário no qual estão imersos os profissionais envolvidos com a assistência à saúde, em particular nos meios hospitalares, que a Hepatite $\mathrm{C}$ também constitui-se em problema de saúde dos 
profissionais da área, com um risco estimado de até 7\%. Igualmente transmitida pelo sangue e secreções, ganha importância principalmente pela indisponibilidade de imunização e profilaxia pós exposição eficaz contrariamente até a realidade da AIDS. Tem sido assim denominada e divulgada nos meios científicos como a epidemia invisivel (LACERDA 2000).

Observamos que até mesmo esse último tipo de denominação agora dado à hepatite $\mathrm{C}$ e cunhada pelos próprios profissionais da saúde, podem acabar, a exemplo do ocorrido com a própria AIDS, num momento ou noutro, por desencadear como bem expressa CZERENIA, sentimentos de maior apreensão nos profissionais atuantes nos meios hospitalares.

Endossando a fala dos entrevistados, agora no que diz respeito à veiculação dos vírus aqui abordados, citamos JAGGER et al. (1998), para o qual as injúrias percutâneas constituem-se de fato nas mais importantes formas de transmissão, notadamente as agulhas utilizadas para fins diagnósticos e terapêuticos, de sutura, lâminas de bisturi. Não causa assim estranheza que boa ênfase seja dada nos discursos ora sob análise à esse cabedal todo de apetrechos enquanto temíveis modos de se adquirir uma doença infecciosa nos campos hospitalares.

Também ao encontro do discurso dos médicos vem os achados do mesmo pesquisador quando constata que as exposições ocupacionais desses profissionais ocorrem com mais freqüência nas cirurgias cardiovasculares, gerais e ortopédicas e a referência de WILLIANS et al. (1994), quando cita que as unidades de emergência reúnem as condições e práticas que expõem, com maior freqüência, os profissionais ao sangue.

Outros setores médicos são considerados de risco à exposição ao sangue, dentre elas as unidades de ginecologia e obstetrícia, dada a natureza das atividades aí desenvolvidas, conforme citado por AHMAD et al. (1998).

Cabe nossa observação que foram os profissionais atuantes nesses tipos de unidades que foram os mais loquazes na expressão do risco que correm em função de suas atuações. 
Observamos, por outro lado, que no discurso médico convive, embora mais ênfase seja dada às viroses de veiculação sangüínea, representadas principalmente pela AIDS e hepatites, e seus modos e ambiências mais factíveis de transmissão, doenças menos up to date como a sífilis e a tuberculose.

É emblemática a frase: "quando um paciente quebra uma perna, você não sabe se ele tem tuberculose, se ele tem AIDS, se ele tem hepatite" ao que permitimo-nos inferir que tem razão a referência uma vez que doença antiga, a tuberculose, de certa forma controlada, retorna paulatinamente ao nosso meio, tendo como principais fatores determinantes, aqueles de ordem estrutural, como a falta de sistemas públicos eficazes, a piora dos programas de controle da doença e a expansão da epidemia da AIDS (KRITSKY et al. 1998).

Complementamos que segundo BRITO (1998), a transmissão nosocomial da tuberculose já é conhecida há algumas décadas e os profissionais de saúde têm risco mais elevado de contrair a infecção que a população em geral. A importância atual da doença é um reflexo do aumento do número de casos na comunidade havendo ainda, fatores que corroboram com a ocorrência nosocomial: a demora na suspeita e no início do tratamento; demora na identificação laboratorial dos pacientes bacilíferos, resistentes ou não aos tuberculostáticos; ausência de estrutura para isolamento do paciente bacilífero; e a não utilização, por parte de profissionais de saúde, da proteção respiratória nos casos em que há indicação, conforme já discutimos na análise da estrutura dos hospitais no concernente à biossegurança.

Sentimos, todavia, nos discursos, que ainda que relacionada com afecções cujas representações foram bastante expressivas, que a tuberculose enquanto risco ocupacional não mereceu tanta ênfase ou, em outras palavras, a tuberculose, não faz parte do imaginário médico com grande força enquanto risco ocupacional.

É possível que o que constatamos se relacione à representação social de menor contundência da doença para os médicos aqui entrevistados e, talvez a própria modéstia de contatos com pacientes tuberculosos experimentadas pelos profissionais. Observamos, contudo, que nossa tendência é a de acreditar mais na primeira 
hipótese, haja vista que não dispomos de dados que comprovem que os médicos venham convivendo mais com a problemática das hepatites e AIDS, em termos de números de pacientes que atendem do que com a problemática da tuberculose.

Embora não tenhamos disponíveis pesquisas que tratem do assunto em foco especificamente com a categoria médica mister citar como ilustração estudo de OLIVEIRA (1996), sobre as representações sociais de trabalhadores de enfermagem atuantes em hospital de referência para a doença. A autora descreveu núcleo temático intitulado "a face negra da tuberculose". Na pesquisa, os entrevistados, argüidos sobre seus conceitos da infecção, a caracterizaram como "doença grave que antigamente só matava pobre e que hoje em dia mata qualquer um".

Bactérias outras, super resistentes, por outro lado, como staphylococcus, pseudomonas, klebsiellas e a escherichia coli, incluem-se no repertório médico como riscos biológicos em potencial para os profissionais durante o desenvolvimento de suas atividades no hospital. Conquanto não tenhamos dados que comprovem diretamente esta possibilidade, muito embora constitua-se em senso comum a composição de uma flora diferenciada nos profissionais atuantes em nosocômios, a realidade da multi resistência das bactérias nas instituições nacionais é incontestável e tem causas múltiplas. Dentre essas, nunca é demais ressaltar, figura a indicação abusiva dos antibióticos pelos próprios médicos; o grande número de preparações farmacêuticas de uso sistêmico compostas por mais que uma droga; e políticas pouco efetivas de controle de uso de antimicrobianos nos hospitais que indicam lacunas estruturais no controle de infecções (PANNUTI e GRINBAUM 1995).

Um terceiro discurso médico refere-se ao risco decorrente da negligência na autoproteção.

\section{DSC dos médicos}

É a falta de cuidado. Todos do grupo da saúde também temos muita culpa disso, porque facilitamos. Não lavamos as mãos. As vezes a gente deixa de ter alguns cuidados de prevenção, assim de uso de material.

Entrevistados 8,13. 
Este discurso expressa o que de alguma forma já foi observado em vários estudos conforme já referido na introdução deste trabalho acerca da baixa aderência às medidas preventivas. O que diferenciamos aqui é que os próprios profissionais admitem que estão em risco pela inobservância das medidas preventivas. LARSON e KRETZER (1995), por exemplo, numa revisão de literatura de dez anos, identificaram 37 estudos descritivos, com o objetivo de mensurar a aderência de profissionais de saúde a determinadas práticas, como a lavagem das mãos e uso de barreiras de proteção. Os resultados foram desanimadores admitem as autoras, com percentagens de aderência muito baixas, na maioria dos estudos. Também PITTET (2001), afirma que, a despeito dos avanços no controle das infecções hospitalares e da epidemiologia, a histórica mensagem de Semmelweis acerca da importância da lavagem das mãos, ainda não é consistentemente interiorizada na prática médica. A aderência à prática da lavagem das mãos, para se ter uma dimensão do problema, é ainda inaceitavelmente baixa e variável de acordo com a categoria profissional e com condições estruturais das instituições. $O$ autor complementa, para ilustrar, que a maioria dos estudos concluem por aumento transitório da aderência após implementação de certas práticas, como educação em serviço e depois tendência à queda na adesão. DEJOY et al. (1996), por seu turno, enfatiza que, a despeito da importante disseminação dos conhecimentos e dos esforços empreendidos pela OSHA, nos Estados Unidos, acerca das precauções universais/padrão, a aderência está sempre aquém do minimamente satisfatório.

Todos os autores são, contudo, unânimes em afirmar a importância, para o alcance de melhores resultados relativos ao assunto, de uma visão multidisciplinar que levem conta inclusive os sentimentos dos profissionais relativo ao assunto.

Um quarto discurso médico acerca do risco aos agentes biológicos durante o desenvolvimento de atividades no hospital, diz respeito ao risco dependente da resistência imunológica de cada profissional. 


\section{DSC dos médicos}

Depende muito da resistência individual de cada um. O fato do médico atender sempre esse tipo de pessoas, cria um pouco, gera no corpo, tipos de anticorpos que já defendem naturalmente o médico, de certos tipos de doenças. Dependemos mais da auto-defesa do organismo do que do contágio dessas pessoas.

Entrevistados : $15,16,18$

Embora não possamos negar o papel da resistência imunológica na proteção a doenças infecciosas, não há como nos furtarmos de destacar que esse tipo de afirmação pode ser preocupante, na medida que seja vista como uma minimização dos riscos por parte dos profissionais médicos. Chama-nos à atenção, a pretensa crença de que o contato regular com os microorganismos os torne necessariamente protegidos. Conforme veremos adiante há uma discurso médico que explicita deliberadamente, não se adotar medidas de auto-proteção para agentes biológicos durante o desenvolvimento de atividades no hospital.

A visão, todavia, de que o fato de exercer as atividades laborais em meio dioturnamente impregnado de agentes potencialmente infecciosos, conferiria suposta imunidade aos agentes biológicos não se constitui em prerrogativa de nossos entrevistados. LINS (1998), por exemplo, em estudo com auxiliares de enfermagem, também detectou esse tipo de representação acerca da imunidade a doenças infecciosas. Tal representação é conferida pelo trabalho contínuo em hospital e é expressa pelo seguinte conteúdo, verbalizado por um dos profissionais entrevistados pela autora: "Eu também não me preocupo mais com esse negócio [risco ocupacional]. Acho que já estou imune".

Observamos, entretanto, que tratam-se os sujeitos do estudo supra mencionado, de auxiliares de enfermagem, para os quais até se admite esperar sentimentos dessa natureza posto que entendemos a possibilidade de que sua formação profissional nem sempre se faz de forma aprofundada.O discurso ora em apreço foi emitido, todavia, por profissionais médicos, dos quais se espera conhecimentos mais bem engendrados. 
Os enfermeiros, a exemplo dos médicos, também apresentam um discurso no qual relacionam o risco de contaminar-se/contagiar-se, particularmente ao contato com sangue e secreções dos pacientes, com ênfase nos materiais pérfuro-cortantes. Esse discurso é até esperado, em função da divulgação mais sistemática, sobremaneira nos últimos anos, dos riscos decorrentes dos acidentes com esse tipo de material na veiculação de agentes biológicos como o HIV e as hepatites B e C, dentre outros patógenos. As idéias centrais, contudo, conforme melhor visualizadas no quadro a seguir, circulam em quatro temáticas principais. Segue-se ao quadro, o discurso mais recorrente, conforme citado.

Quadro Síntese - Suas atividades de rotina envolvem, de algum modo, algum risco de contaminação ou contágio pessoal? (Profissional enfermeiro)

\section{Idéias Centrais}

\begin{tabular}{|c|c|c|c|}
\hline $\begin{array}{l}\text { O risco decorrente } \\
\text { do contato com } \\
\text { sangue, secreções, } \\
\text { doentes com } \\
\text { infecções e } \\
\text { acidentes com } \\
\text { pérfuro-cortantes. }\end{array}$ & $\begin{array}{l}\text { O risco decorrente } \\
\text { da falta de equipa- } \\
\text { mentos de proteção } \\
\text { individual. }\end{array}$ & $\begin{array}{l}\text { O risco decorrente } \\
\text { do desconhecimen- } \\
\text { to do diagnóstico } \\
\text { do paciente. }\end{array}$ & $\begin{array}{l}\text { O risco decorrente } \\
\text { da negligência na } \\
\text { auto-proteção. }\end{array}$ \\
\hline
\end{tabular}

Idéia central- O risco decorrente do contato com sangue, secreções, doentes com infecções e acidentes com Pérfuro-cortantes.

\section{DSC dos enfermeiros}

Há o risco direto de contaminação através do sangue ou de outras secreções do paciente e doenças infecto- contagiosas que podem ser transmitidas aos profissionais, além de materiais pérfuro-cortantes.

Entrevistadas $1,2,3,4,6,7,8,9,10$.

Para entendermos as representações dos enfermeiros acerca do risco que entendem correr durante o desenvolvimento de suas atividades, vale a pena uma incursão no histórico das preocupações com a contaminação acidental de profissionais da área da saúde com vírus veiculados pelo sangue que se desencadeiam a partir de 1981, com os primeiros relatos de casos de pacientes acometidos pela AIDS e que culminam 
com diversos estudos a princípio nos EUA, e também nas Instituições nacionais, buscando-se dimensionar a ocorrência de acidentes com materiais pérfuro-cortantes, considerados os mais problemáticos na veiculação ocupacional de agentes patogênicos pelo sangue. Assim, em trabalho de revisão de estudos que versam sobre acidentes com materiais pérfuro-cortantes, desenvolvidos logo proximamente aos primeiros relatos da doença AIDS, por exemplo, ROWE e GIUFFRE (1991), verificaram que 60 a $90 \%$ de acidentes em centros médicos ocorreram no pessoal da equipe de enfermagem. LEVINE e GODOY (1992), afirmam que os profissionais mais expostos a agentes biológicos transmitidos por via sangüínea, no hospital, são de fato os da equipe de enfermagem, seguidos pelos médicos, em especial os cirurgiões, pessoal de laboratório, de lavanderia e limpeza.

Também no Brasil boa ênfase ao tema foi dada, vários estudos desenvolvidos e ampla divulgação nos meios hospitalares. Assim é de se supor que o assunto sangue e materiais pérfuro-cortantes venha à baila quando o assunto é risco de contaminação/contágio nos meios hospitalares.

Depreendemos também, das falas dos enfermeiros, um segundo discurso que diz respeito ao risco de contaminação/contágio pessoal decorrente da falta de infraestrutura e equipamentos de proteção individual nas instituições.

Idéia Central - O risco decorrente da falta de equipamentos de proteção individual

\section{DSC dos enfermeiros}

Tem-se pouco material. A questão da capa, óculos, máscaras. A gente tem bastante deficiência em relação a isso. A gente tem máscara, mas em pouquíssima quantidade, o que não dá para a equipe toda. A qualidade do material, questão da luva e tal que não são de boa qualidade. Procura-se uma luva para fazer uma punção e não acha. As aspirações são feitas sem óculos. Os materiais pérfurocortantes são desprezados em locais inadequados. Muitas vezes, o funcionário vai desprezar material, ele se fura, se contamina. A estrutura do hospital não permite que se proteja adequadamente. Não se tem isolamentos.

Entrevistadas 5,9,11,13. 
Esse é um discurso sintomático, que revela as condições de infra estrutura dos hospitais estudados e, extensivamente, parte substancial das instituições nacionais que, salvo exceções de entidades privadas dirigidas a usuários de maior poder aquisitivo e uma ou outra instituição pública privilegiada em termos de dotações orçamentárias, vêm enfrentando reduções de investimentos em manutenção e conservação de equipamentos e instalações, haja vista inclusive a pulsão tecnológica no campo da terapêutica que está cada vez mais a exigir constante incorporação de novos produtos tecnológicos e equipamentos médicos de diagnóstico, implicando em altos investimentos em determinada área, a despeito de outras.

Não causa estranheza, em conseqüência, que os enfermeiros expressem o risco que correm em função da falta de materiais e equipamentos de proteção individual. Em verdade o risco é visto aqui enquanto limitações das condições objetivas de trabalho.

Para ilustrar essa percepção podemos citar TAKEDA (1996), que refere ser infreqüente a preocupação das administrações hospitalares com aspectos relacionados à proteção, promoção e manutenção da saúde de seus empregados. Situação essa de extrema contradição, posto que um lugar que se presta a salvar vidas e recuperar a saúde das pessoas é o mesmo lugar que favorece o adoecer daqueles que nela trabalham. Há também que aludirmos os problemas organizacionais, que muitas vezes conferem lacunas desnecessárias, sob o argumento da economia de recursos. Um dos exemplos é a compra de materiais mais baratos, mas de qualidade duvidosa. Tal atitude acaba gerando, muitas vezes, ao contrário do esperado, custos ainda maiores, além, obviamente, da exposição de profissionais a riscos desnecessários .

Um outro discurso dos enfermeiros diz respeito ao risco de contaminação/contágio decorrente do desconhecimento do diagnóstico do paciente. Esse discurso assemelhase, em parte, ao discurso dos médicos que referem ver riscos no atendimento de pacientes desconhecidos. No caso dos enfermeiros, a ênfase apreendida é no contato de prazo razoável com o paciente, durante sua internação e a surpresa com um eventual diagnóstico de doença infecto-contagiosa. É emblemática a frase: "O 
paciente vai ser diagnosticado muito tempo depois que a gente teve contato. $O$ paciente está ali com uma tosse e tal, então a gente não desperta".

Idéia central - O risco decorrente do desconhecimento do diagnóstico do paciente

\section{DSC dos enfermeiros}

O paciente vai ser diagnosticado muito tempo depois que a gente teve contato. $O$ paciente está ali com uma tosse e tal, pode ser uma provável TB, então a gente não desperta, ou, às vezes, o médico, o que é pior, saber e não dizer.

Entrevistadas 9,12.

Esse repertório, nos parece, de alguma forma, direciona-se para a problemática da pauperização dos conhecimentos relativos às formas de transmissão das doenças e à sua débil difusão no meio hospitalar e também à uma certa visão de espectador dos enfermeiros, ou dito de outra forma, transparece uma representação de relativa alienação, o que nos leva a algumas indagações. Não obstante ser privativo ao profissional da medicina, o estabelecimento do diagnóstico médico e tratamento, sem entrarmos aqui nas discussões de cunho mais corporativos, não caberia também aos demais profissionais envolvidos na assistência e, em especial aos enfermeiros, estar preparados para o desenvolvimento de um raciocínio clínico mínimo que lhes permitisse identificar eventuais casos de doenças transmissíveis e, em subseqüência, instituir medidas para sua proteção, entendidas aqui como isolamentos apropriados, e de sua equipe?

E ainda, estariam os enfermeiros perfeitamente cientes acerca das precauções que incluem cuidados padrões, de uso universal, independente dos diagnósticos dos pacientes?

Voltando ao discurso, chama-nos a atenção, por outro lado, a alusão dos enfermeiros ao "médico saber [o diagnóstico] e não dizer". Ao que permite-nos indagar: como se dá a integração das equipes nessa situação tão singular, na qual todos os envolvidos necessitam da mesma proteção? A representação dos enfermeiros parece dar como normal esse tipo de atitude. O discurso ora em pauta, malgrado sua 
sutileza, parece merecer discussões que ultrapassam o tema desse trabalho, para ganhar contornos outros, inclusive relacionados à deontologia e à ética.

Para finalizar, há um quarto discurso dos enfermeiros, o qual relaciona o risco à suposta negligência profissional na auto-proteção.

Idéia central - O risco decorrente da negligência na auto- proteção

\section{DSC dos enfermeiros}

Às vezes, a gente não tem assim aquele cuidado. É tanta coisa que você não tem tempo e, às vezes você não leva tão à sério.

Entrevistada 12 .

Para discutir esse discurso acreditamos ser válida uma pequena incursão nas palavras de DEJOURS (1992). O autor categoriza os riscos, para fins de estudar os efeitos do trabalho sobre os trabalhadores, em três niveis: o risco real, suposto e residual. $O$ primeiro é caracterizado como aquele que está na esfera de controle ou responsabilidade do empregador. Enquadra-se aí, no caso desse estudo, as condições decorrentes das inadequações de infra-estrutura . O segundo, o risco suposto, como o próprio nome anuncia, é aquele que se supõe como de conhecimento dos trabalhadores, configurados pelos ensinamentos, campanhas de prevenção, dentre outros. Por fim, o risco residual é aquele de total responsabilidade do indivíduo - o profissional conhece o risco, dispõe da infra-estrutura necessária à sua proteção, mas não se protege.

O risco decorrente da negligência na auto-proteção, idéia central apreendida do discurso dos enfermeiros, incluir-se-ia nessa última categoria proposta por DEJOURS, o risco residual - "As vezes você não leva tão a sério", anunciam os enfermeiros.

Conforme já citado, a problemática da aderência às práticas de proteção contra infecções é bastante complexa e deve ser abordada sob diferentes enfoques. A maioria dos autores está convencida de que as abordagens que levam em conta as características individuais da pessoa talvez sejam as mais indicadas. 
De todo modo, vários estudos comprovam não haver confluência entre o conhecimento das medidas de proteção e seu emprego na prática. Estudo brasileiro de SOUZA (1994), detectou, por exemplo, que a percentagem de enfermeiros e de auxiliares de enfermagem que conheciam, à época, as precauções universais, era significativamente maior do que os que as aplicavam, caracterizando o que a autora denominou de displicência.

Necessário, no entanto, analisarmos a suposta displicência, aqui no caso especifico de nossos entrevistados, à luz de questões mais de fundo.

Observe-se que os enfermeiros trazem para si a responsabilidade de não levar "tão $a$ sério" mas fazem referência explícita ao "é tanta coisa para fazer". Em decorrência disso, faz-se necessário refletirmos acerca da carga de trabalho imposta aos enfermeiros. Certamente se essa carga de trabalho se faz desproporcional ao tempo, algumas práticas deixarão de ser realizadas, principalmente as menos "visiveis", "as menos contundentes", "as menos cobradas" e até mesmo aquelas que, em tese, possam lesá-los mais que aos seus próprios pacientes, a exemplo das práticas de auto-proteção. Não se constitui novidade que as condições de trabalho dos enfermeiros na maioria das instituições nacionais, não são satisfatórias, realidade esta não diferente, absolutamente, daquela vivenciada pelos profissionais sujeitos deste estudo: vários pacientes sob sua responsabilidade, diferentes atividades gerenciais $\mathrm{e}$ assistenciais desenvolvidas ao mesmo tempo; rodízios, plantões, cargas horárias extenuantes. Seria redundante ressaltar que todos esses fatores corroboram para práticas não condizentes com algo próximo do ideal na auto-proteção. Isso é tão verdadeiro, que é expresso como natural nas produções discursivas. "É tanta coisa que você não tem tempo".

Se de um lado, os médicos são enfáticos ao expressar os riscos biológicos a que estão submetidos durante o desenvolvimento de suas atividades no hospital e, de outro, os enfermeiros os admitam igualmente com relativa veemência, também os auxiliares e técnicos de enfermagem mostram-se incisivos em respeito ao assunto. 
Observamos, todavia, que enquanto o discurso médico versa com maior ênfase sobre a problemática do sangue e do desconhecimento da história pregressa dos pacientes na constituição dos riscos biológicos nos hospitais, e os próprios enfermeiros destacam também o sangue e, particularmente os problemas de infra-estrutura hospitalar na constituição do risco, os discursos dos auxiliares e técnicos, embora de igual modo façam referência ao sangue e secreções, apresentam o risco, preponderantemente, como uma situação bem mais pulverizada. O fragmento de discurso aqui compilado dá essa medida "Todo trabalho direto com o paciente já tem risco de contaminação, não tem jeito ", "os profissionais já correm risco desde a hora que adentram o hospital", "Tem contaminação porque é um hospital".

Quadro Síntese - Suas atividades de rotina envolvem de algum modo, algum risco de contaminação ou contágio pessoal? (Auxiliares e técnicos de enfermagem)

\section{Idéias centrais}

\begin{tabular}{|c|c|c|c|c|}
\hline $\begin{array}{l}\text { O risco inerente } \\
\text { ao contato com } \\
\text { o paciente, suas } \\
\text { secreções, e ao } \\
\text { ambiente } \\
\text { hospitalar. }\end{array}$ & $\begin{array}{l}\text { O risco decorrente } \\
\text { do desconhecimento } \\
\text { do diagnóstico do } \\
\text { paciente. }\end{array}$ & $\begin{array}{l}\text { O risco } \\
\text { decorrente da } \\
\text { negligência na } \\
\text { auto-proteção. }\end{array}$ & $\begin{array}{lr}\text { O risco } \\
\text { decorrente da } \\
\text { ineficácia e a } \\
\text { falta dos EPIs. }\end{array}$ & $\begin{array}{l}\text { Não se corre } \\
\text { risco. }\end{array}$ \\
\hline
\end{tabular}


Idéia central - O risco inerente ao contato com o paciente, suas secreções e ao ambiente hospitalar.

\section{DSC dos auxiliares e técnicos de enfermagem}

Todo trabalho direto com pacientes já tem risco de contaminação, não tem jeito. Os profissionais já correm risco desde a hora que adentram ao hospital. Tem contaminação porque é um hospital. Tem-se contato direto com paciente, paciente com problema pulmonar, com infeç̧ão respiratória, tuberculose, hepatite, HIV, e outras mais. Procedimentos tipo aspiração, pode respingar na boca, nos olhos. $E$ também a manipulação de materiais, caso das agulhas, material cortante. Tem que tomar cuidado para não espetar o dedo nos escalpes. Tem que se proteger principalmente do xixi, das eliminações e sangue também, essas coisas todas que a gente manuseia.A gente lida com sangue tanto da operação ou dos curativos, às vezes o paciente está com dreno.Tem as paridas, os lençóis. Puérpera é igual sangue. Porque a gente posiciona as pacientes, punciona veia, tem a tipagem, essas coisas.Pacientes acidentados, sangrando muito. Pegamos pacientes graves, a maioria com infecções, hepatite, meningite, DPOC. Existe, sempre existe o risco. A gente usa todos os nossos métodos e cuidados. Tem a máscara que nós usamos, a luva, mas mesmo assim não é suficiente.

O discurso em tela, ainda que venha a tratar de temas também presentes nas representações dos demais profissionais, nos parece, ser indicativo de que o imaginário social desses profissionais acerca dos riscos mostra-se peculiar. $O$ fato de situar o risco como inexorável pode calcar nos profissionais um medo exacerbado no desenvolvimento de suas atividades, gerando stress desnecessário, insegurança, bem como uma atitude defensiva em relação aos pacientes. Ou então, numa atitude oposta, mas igualmente problemática, um conformismo tal que possa levá-lo a desconsiderar a necessidade de se adotar medidas de auto-proteção. Vejamos: "todo trabalho direto com pacientes já tem risco de contaminação, não tem jeito". 
Outro discurso apreendido foi o do risco decorrente da falta de cuidado. Os profissionais entendem que o risco existe, na medida em que não adotam as medidas preventivas indicadas, ou seja, parecem assumir como de sua responsabilidade uma eventual contaminação/contágio, ainda que façam alusão a condições estruturais adversas - "as vezes se relaxa mesmo" - "em outras tem pouca gente ou não dá tempo da urgência, na pressão".

Idéia central - O risco decorrente da falta de cuidado

\section{DSC dos auxiliares e técnicos de enfermagem}

Envolve risco se não se tomar cuidado. Só se eu próprio não me proteger. Depende de ter cuidado, trabalhar com cuidado, para que nada, se houver alguma coisa venha te contaminar. No caso de puncionar veia sem luva. As vezes tem risco, porque eu mesmo não uso luvas para certos procedimentos, punção na veia com luva não dá. Ás vezes, a gente no corre-corre, uma agitação tão grande, que às vezes a gente esquece até de calçar uma luva. Muitas vezes é culpa da gente. A gente entra no dia a dia e termina esquecendo coisas básicas que é usar uma luva, se proteger, uma máscara. Às vezes se relaxa mesmo. Em outras tem pouca gente ou não dá tempo, na urgência, na pressão.Porque é tirando um paciente da sala e colocando outro.

Entrevistados 3,8,12,14,17,20,27,33.

LINS (1998), também capta, sentimentos semelhantes aos aqui apresentados acerca do envolvimento de riscos durante o desenvolvimento de atividades laborais, entrevistando auxiliares de enfermagem, conforme pode ser confirmado pelas falas: "acidente de trabalho vai ocorrer quando a pessoa trabalha sem paciência"; "A gente se contamina quando trabalha rápido"; "risco de trabalho é ser imprudente ou não dar atenção às orientações de perigo e por não agir com precaução "; "Risco é não ter conhecimento de certos materiais que vai utilizar".

Depreendemos dessas falas que os profissionais, além de perceberem os riscos que correm, não culpam a outrem pela a exposição a esses riscos, senão a si mesmos. 
Mister enfatizarmos que, embora seja desejável a postura de valorizar a questão da não adoção das medidas preventivas como elemento importante na constituição do risco, não podemos perder de vista os elementos estruturais nominados por alguns autores como risco real, como DEJOURS (1992), ou seja, os riscos cujo controle está na esfera de ação do empregador e, portanto, de sua responsabilidade.

SUAZO (1999), dissertando sobre acidentes de trabalho, que de algum modo relaciona-se com o tema de nosso estudo, refere que em decorrência da submissão e desinformação sobre aspectos básicos acerca da atividade laboral, por parte dos trabalhadores, ou adaptação às condições inadequadas, é comum a ocorrência de acidentes. Enfatiza ainda que, muitas vezes, o trabalhador assume inteira responsabilidade sobre o ocorrido, atribuindo-o à sua imperícia, mesmo que o evento tenha sido provocado pela falta de condições ambientais ou pela questão da desorganização do trabalho, dentre outros.

A perspectiva de se ter o próprio trabalhador como foco das causas de acidentes que lhe acontece é discutida ainda por autores como DELA COLETA(1991) citado por SUAZO(1999, p13), que refere que tanto os próprios trabalhadores, como os empresários, membros do governo, técnicos em segurança, tendem a explicar a ocorrência dos acidentes de trabalho como resultante de características negativas dos trabalhadores tais como brincadeiras, descuidos, desatenções, despreparos, incapacidades e outras. $\mathrm{COHN}$ et al. (1985), por sua vez, afirmam que, especialmente em nosso país, a atribuição da culpa aos empregados pela ocorrência dos acidentes ocupacionais, é evidente. Citam as próprias campanhas que induzem os trabalhadores a acreditarem que são os responsáveis (únicos) pelos eventos e LAURELL e NORIEGA (1989), vão além, quando insistem que o termo "risco ocupacional" pressupõe elementos isolados entre si, na dinâmica global do processo de trabalho, o que não é verdadeiro na prática. Os autores defendem, em contrapartida, o emprego da categoria carga de trabalho como elementos do processo de trabalho, que inter-atuam entre si com o corpo do trabalhador, gerando os processos de adaptação que se traduzem em desgaste. 
Ilustrativo do contexto dos emitentes do discurso aqui sob análise citamos LACERDA (2000), para quem a dinâmica de organização dos hospitais, embora um setor típico terciário no que se refere à produção de serviços, se assemelha muito ao setor secundário (produção de bens industriais), quando analisada sob o prisma da variedade de processos de trabalho, com suas divisões técnicas e sociais bem estabelecidas. Divisões essas que favorecem diferentes valorizações das distintas forças de trabalho, nas quais o médico detém papel hegemônico e a enfermagem debate-se com a sua própria divisão interna inerente à categoria, na qual o enfermeiro fica com a função de líder, mas sem as benesses positivas de efetiva liderança, e os demais membros da classe como executores.

Some-se ao quadro, a ênfase na quantidade de produção (o discurso sob análise é bastante ilustrativo dessa condição - "[...] às vezes a gente no corre-corre, uma agitação tão grande [...] em outras tem pouca gente ou não dá tempo, na urgência, na pressão [...]" e a alienação produzida nas categorias mais relacionadas ao fazer, do que ao pensar - "[..] a gente entra no dia-a-dia e acaba esquecendo coisas básicas".

Um terceiro discurso, também dos auxiliares e técnicos de enfermagem, diz respeito ao risco decorrente do desconhecimento do diagnóstico do paciente, alusão também presente, conforme já discutido, nos discursos dos médicos e enfermeiros, ainda que com enfoques diferentes.

Idéia central: O risco decorrente do desconhecimento do diagnóstico do paciente

\section{DSC dos auxiliares e técnicos de enfermagem}

A gente nunca sabe o que o paciente tem, pode ser algo contagioso. Depois é que a gente vai saber. De repente, o médico pede os exames e chega resultado positivo para tuberculose, depois de muito tempo que a gente ficou exposto.Paciente de pronto socorro vai chegando e a gente não conhece. $\dot{E}$ paciente com meningite. Então a gente fica exposto porque nunca sabe.

Entrevistados 9,10,12,13,14,26,38,41. 
O foco do discurso dos auxiliares e técnicos é que eles nunca sabem o que os pacientes têm e que quando passam e vem saber, o contato com o paciente já vem se fazendo há muito tempo. Esse é um discurso que certa forma desvela a problemática de possível lacuna no estabelecimento de uma suspeita diagnóstica por parte dos médicos, seguida da demora na realização de exames complementares e obtenção dos resultados e mesmo até na fragilidade de informações existentes nos prontuários dos pacientes. Também demonstra a própria desorganização do processo de trabalho dos auxiliares e técnicos de enfermagem, que, em tese, hão que ser supervisionados pelos enfermeiros, responsáveis pela elaboração dos planos assistenciais de enfermagem para os pacientes. Ora, permitimo-nos dizer, se existe um plano de assistência estruturado, levando-se em conta as condições e necessidades dos pacientes, nos parece prescindir-se da obrigatoriedade de um resultado de exames em mãos para se por em prática medidas de proteção, salvo condições bastante específicas.

Fica também patente no discurso ora sob análise, uma tendência dos profissionais de valorizarem a adoção de medidas preventivas quando conhecidos os diagnósticos dos pacientes. Essa atitude contraria o que preconiza, conforme já ressaltado, as precauções universais/padrão, que tratam mais especificamente dos agentes veiculados pelo sangue e secreções, fonte maior para riscos biológicos em hospitais, e cuja essência recai sobre a assertiva de que os cuidados devam ser empreendidos independentemente de diagnóstico.

Conteúdos semelhantes ao discurso ora em discussão, dos auxiliares e técnicos de enfermagem, também foram verificados por LINS (1998), para as mesmas categorias profissionais. Vejamos o exemplo de conteúdo verbalizado e compilado do trabalho da pesquisadora: "Na admissão do paciente, sem diagnóstico sempre, descobre-se que este é portador de doença infecciosa. Já passamos muitos dias, sem nenhuma proteção com o paciente"

Necessário citar, contudo, que alguns autores já se interpõem à visão das precauções universais/padrão e a pouca ênfase nos diagnósticos dos pacientes, quando defendem que o recurso de conhecer previamente o cliente e, consequentemente, identificar 
aqueles de risco, deveria fazer parte do conjunto das estratégias de prevenção dos riscos biológicos porque passam os trabalhadores da saúde nos hospitais, aspecto que não vem sendo, na opinião dos próprios pesquisadores, considerado na literatura pertinente (LACERDA 2000).

É possivel, entretanto, que conquanto incontestável a importância da construção de melhores históricos e da relevância de se melhor conhecer os pacientes, a definição, a priori, de paciente de risco, possa suscitar questões mais ampliadas, incluindo-se as de ordem ética, que fujam ao legítimo objetivo de melhor proteger o trabalhador.

Voltando ao discurso em discussão, outra questão que se permite colocar é se, uma vez conhecido o diagnóstico do paciente, os auxiliares e técnicos de enfermagem compartilham dessa informação que, em que pese posições em contrário, não se constitui essencial para o emprego de medidas básicas de proteção, mas tem sua importância no seguimento dos pacientes, bem como na incorporação de cuidados específicos.

Visão de SIQUEIRA et al. (1995), explica a relativa alienação abstraída do discurso dos auxiliares de enfermagem, na medida em que considera que as alterações tecnológicas ocorridas no trabalho em saúde têm implicado, de um lado, em um processo mais coletivo, na medida em que as tarefas de um determinado grupo profissional depende do outro e, de outro, numa concentração das atividades mais reflexivas e de maior autonomia em alguns grupos profissionais, havendo uma proporção cada vez maior de trabalhadores com atividades meramente rotineiras e padronizadas.

Observemos que, ainda que os auxiliares e técnicos de enfermagem devam ser providos de acompanhamento de suas atividades, como inclusive postulam as organizações de classe, isso não quer dizer, ao contrário, que eles não devam ter o domínio sobre o seu fazer. Tomemos como exemplo a questão da biossegurança aqui implicada. Um trabalho esvaziado de conteúdo e alienante pode colaborar com uma situação de risco nas instituições hospitalares, na medida em que não se busca, dos 
seus executores, uma compreensão mínima de contexto, que inclui reflexão contínua sobre seus atos e compartilhamento das informações necessárias.

Dos dois últimos discursos dos auxiliares e técnicos de enfermagem acerca da existência de risco biológico durante o desenvolvimento de suas atividades no hospital, um deles refere-se ao risco decorrente da ineficácia dos equipamentos de proteção individual, particularmente da desproteção conferida pelas luvas, quando de acidentes com materiais pérfuro-cortantes .

Conforme já citado neste trabalho, o risco decorrente de acidentes com materiais pérfuro-cortantes tem sido bem documentado. Também tem sido enfatizado que esses acidentes ocorrem com maior freqüência entre os componentes da equipe de enfermagem, ainda que uma análise mais apurada das pesquisas sugira que a incidência e prevalência dessas ocorrências relacionam-se antes com as funções exercidas e os procedimentos realizados, do que propriamente com a categoria profissional (LACERDA 2000). Por outro lado, os autores são unânimes em defender a importância da aderência dos profissionais às medidas preventivas.

Enfatiza-se a lavagem das mãos e o uso de EPIs, onde se incluem as luvas, para as atividades que envolvam a possibilidade de contato com sangue e secreções e evidencia-se que o uso desses mesmos equipamentos não reduz os riscos à zero, mas ajudam na minimização das exposiçôes. No caso em particular das luvas, estas reduzem a quantidade de sangue inoculado em até $75 \%$ e, em conseqüência, o grau de risco de infecção (CHAMBERLAND et al ,1995 citado por LACERDA 2000 $\mathrm{p} 76)$.

A obtenção de melhores resultados na redução dos riscos passam, contudo, por uma conjunção de fatores, dentre eles o uso de equipamentos de proteção individual, realização dos procedimentos dentro das normas de segurança, boa perícia técnica, adequadas condições de ambiência, dentre outras. Essas informações devem ser de domínio dos profissionais envolvidos na assistência hospitalar.

Para ilustrar que o problema do risco biológico não se resume à problemática dos EPIs, ARAÚJO e LACERDA (1997), detectaram, por exemplo, que a principal causa 
atribuída à ocorrência de acidentes envolvendo materiais pérfuro-cortantes, em unidade de emergência, em hospital paulistano, foi atribuída à agitação dos pacientes e à conseqüente dificuldade de realizar os procedimentos sem a ajuda de outro profissional, ou seja, sem a necessária condição de segurança para a situação específica.

Não se pode deixar de levar em conta, todavia, a possibilidade de que, ao se considerar em risco, mesmo com o emprego de EPI, pelo fato de não ter confiança na proteção conferida pelo equipamento. o profissional se afaste da adoção das precauções necessárias. SOUZA (1999), detectou, por exemplo, em estudo empreendido em hospitais da cidade de São Paulo, que em muitos acidentes com materiais pérfuro-cortantes, os acidentados encontravam-se sem luvas, em desacordo às preconizações.

Idéia central- O risco decorrente da ineficácia e da falta de EPIs

\section{DSC dos auxiliares e técnicos de enfermagem}

Mesmo com a proteção da luva, você pode se furar com uma agulha. Na hora de tirar a lâmina do bisturi do cabo, ela pode desconectar e furar a sua mão. Quando você está lavando materiais as luvas são finas, podem perfurar. A luva não é um meio assim de segurança, porque ela passa segurança para a gente, no caso de não se sujar, mas, no caso de se furar, não protege. Não dá essa proteção toda.E falta máscaras, falta óculos, falta...Tem a máscara que nós usamos, mas mesmo assim, não é suficiente. Infelizmente a gente não tem, na hora de trocar o soro, uma luva, mas deveria. Então é um risco.

Entrevistados $12,21,24,34,40$.

Por último, há o discurso que representa aqueles que não acreditam na possibilidade do risco biológico no desenvolvimento de suas atividades, a não ser pelo contato com situações concretas como ilustrado a seguir. 
Idéia central - Não se corre risco

\section{DSC dos auxiliares e técnicos de enfermagem}

Geralmente não. É pouco. Não entro em contato com contaminação em ortopedia. Cirurgia ortopédica não tem contaminação. É muito dificil acontecer. Só se chegar assim uma meningite. Não corre muito risco não. É que a gente atende uma infecção mas é viral mesmo, não tem risco não.

Entrevistados 28,31.

Esse discurso é sintomático de que existe ainda no imaginário dos profissionais a baixa plausibilidade do risco. Isso pode arremeter a comportamentos nos quais a possibilidade de contaminação pessoal não é considerada e, consequentemente medidas de proteção não sejam adotadas. Embora aparentemente essa concepção não se constitua universal, ainda assim, esse tipo de entendimento tem que ser levado em conta como uma realidade na busca de melhores soluções para a problemática do emprego de medidas de biossegurança nas instituições.

\subsection{O proteger-se}

Os discursos médicos sobre o proteger-se de contaminação/contágio nas atividades no hospital foram divididas em três categorias de análise, conforme ilustra o quadro aposto na seqüência.

Quadro Sintese - Você se protege de contaminação e de contágio em suas atividades no hospital? (profissionais médicos)

Idéias centrais

\begin{tabular}{|l|l|l|l|l|}
\hline $\begin{array}{l}\text { A proteção como um } \\
\text { hábito. }\end{array}$ & $\begin{array}{l}\text { A relativa proteção, } \\
\text { dependente das condições } \\
\text { de infra-estrutura do } \\
\text { hospital. }\end{array}$ & $\begin{array}{l}\text { A proteça não rotineira, } \\
\text { dependente do tipo de } \\
\text { paciente. }\end{array}$ \\
\hline
\end{tabular}

A primeira idéia central refere-se à proteção como um hábito. Sua ênfase recai na observância das normas e no uso de equipamentos de proteção individual. 
Idéia central: A proteção como um hábito

\section{DSC dos médicos}

A gente tem o hábito de usar gorro, usar máscara e obviamente luva, para qualquer procedimento, além da rotina natural de lavagem das mãos. Procura-se proteger-se de qualquer contato com sangue de paciente, usando luvas sempre e outros equipamentos de proteção individual, incluindo o óculos que normalmente não tem nos hospitais. Não se encapa agulhas. Faz-se aquilo que se preconiza. Esse negócio de uma vez eu me protejo, outra vez eu não me protejo, não pode ser. Isso tem que ser sempre. E orientar também as pessoas que estão ao nosso redor, que isso é importante. Seja até no andar no hospital sem sapato adequado. Que às vezes "Ah, esse ambiente é muito limpo".

Entrevistados $3,5,10,11,12,14,16,17,19$

Observemos o quanto se ressalta os cuidados com o contato com sangue. Preocupação que certamente tem suas raízes, conforme já visto, na idéia de que este é o meio mais freqüente de veiculação de agentes patogênicos para os profissionais da saúde na atualidade, como as hepatites e o HIV, e também na própria representação social que essas doenças tem para os profissionais conforme já nos referimos. Depreendemos ainda do discurso, que os fundamentos das precauções universais/padrão fazem parte, de algum modo, do universo de conhecimentos médicos: "Esse negócio de uma vez eu me protejo, outra vez eu não me protejo, não pode ser. Isso tem que ser sempre".

A lavagem das mãos é lembrada, adicionalmente, como rotina natural, embora as pesquisas indiquem que na prática, a realidade não aponte tanta naturalidade, conforme teremos oportunidade de ilustrar adiante com estudos que focam a prática médica relacionada ao tema específico.

De outra parte, cita-se EPIs, como o gorro, que não tem nenhuma eficácia na proteção aos profissionais para agentes biológicos, constituindo-se, em verdade, mais como um meio higiênico para proteger os próprios pacientes do que propriamente o profissional. Cita-se também a máscara, que pelo contexto, trata-se do modelo 
cirúrgico para a proteção contra eventuais respingos de sangue e secreções e, em destaque, as luvas, mais uma vez ressaltando a importância atribuída aos agentes biológicos veiculados pelo sangue, principalmente através do contato com as mãos, e, de igual modo, a menção à técnica do não re-encape de agulhas. O óculos de proteção é incluído como artefato de proteção, mas como o grande ausente das instituições hospitalares estudadas, ou seja, a proteção é considerada habitual, mas auto-limitada pelas condições de infra-estrutura. Tal discurso é mais forte na segunda categoria de análise, conforme veremos adiante.

Nesse discurso, depreendemos também uma relativa preocupação com a problemática de manter os membros da equipe informados acerca da importância de instituir as medidas de proteção e, de certa forma, juizo de valor de que não são todos os profissionais que estão suficientemente preocupados com o assunto - riscos biológicos e proteção profissional. A frase aqui compilada ilustra o sentimento apreendido "ah, esse ambiente é muito limpo".

Observemos que o discurso em foco não tem consonância no que diz respeito ao entendimento da proteção como um hábito quando confrontados com dados da bibliografia pertinente, face que a maioria deles detecta baixa adesão às medidas. Isso nos faz supor que os médicos imaginem-se protegendo-se, sem contudo adotar rotineiramente de forma correta as medidas de auto-proteção.

Citemos HENRY et al. (1994), por exemplo, em pesquisa desenvolvida em duas emergências norte americanas nas quais observaram que luvas foram utilizadas apropriadamente em $67,2 \%$ dos procedimentos para os quais eram indicadas, seguidas do uso dos óculos $(50,7 \%)$, máscaras $(16,0 \%)$ e aventais $(15,3 \%)$. Os pesquisadores consideraram, frente aos resultados, que o uso dos equipamentos de proteção individual ocorreu abaixo do esperado ainda que os profissionais os tivessem completamente à disposição. Verificaram ainda, dado dos mais relevantes, que não havia confluência entre o uso referido e o uso objetivamente observado.

MICHALSEN et al. (1997), em pesquisa empreendida em serviços médicos em três regiões americanas, detectaram baixa aderência às medidas de barreira quando analisadas em seu conjunto: $31 \%$ a $38 \%$. Detectaram, todavia, que a referência à 
adoção de determinados cuidados é mais freqüente em detrimento de outros. Registraram, por exemplo, o uso de luvas em $94 \%$ das indicações e adequado descarte de materiais pérfuro-cortantes em $92 \%$ das oportunidades. Em contrapartida, o uso de capas foi considerado baixo - $55 \%$, bem como a prática de não re-encape de agulhas - 56\%. Verificaram também, por regressão logística, que os médicos de maior idade e que se reportaram estar submetidos a maiores pressões no trabalho são os menos aderentes às medidas de auto-proteção. MOORE et al. (1998), estudando a aderência de médicos pediatras às precauções universais em hospital de atenção terciária, nos Estados Unidos, observaram 53,9\%, de um total de 128 procedimentos realizados de acordo com o preconizado pelo CDC. A estatística é considerada pelos autores aquém do desejável. AKDUMAN et al. (1999), por outro lado, procedendo observação de 597 profissionais atuantes em 76 cirurgias em Hospital Universitário do Missouri, Estados Unidos, verificaram uso regular de óculos de proteção por parte de $32 \%$ do staff e dupla luva, em concordância com o preconizado, em $28 \%$ dos componentes envolvidos em cirurgias ortopédicas. EVANOFF (1999), detectou a não utilização de máscaras em 32,2\% dos eventos para os quais eram indicadas, seguidos do não uso de óculos - 22,2\%, aventais - $5,6 \%$ e luvas - 3,0\%, a partir de análise de gravações em vídeos, de procedimentos realizados em unidades de emergência do mesmo hospital.

De todo o exposto, em que pese a firme convicção dos emitentes deste discurso, que trata da proteção como um hábito, não obstante emblemático de um ideário a ser perseguido pelos profissionais e gestores hospitalares, parece mais a representação de um desejo, permitimo- nos expressar, do que uma prática sempre corrente. Isto não quer dizer que o discurso não seja verdadeiro, pelo contrário. Isso quer dizer, nos parece, que existem parcelas substantivas de profissionais que pensam e querem se proteger, mas que os mecanismos nos quais estão inseridos os afastam das práticas recomendadas. Mecanismos esses, alguns já bastantes discutidos pela literatura como os de ordem estruturais e outros pouco menos tratados, mas igualmente importantes, haja vista os de ordem profissional, relacionados com a formação, dentre outros.

Possivelmente, respostas mais bem engendradas sejam passíveis de se conseguir, com estudos que se aprofundem ainda mais nas representações sociais. Não apenas 
nas pesquisas, mas também na sua devolutiva às práticas que intentem a modificação da realidade posta, por exemplo, através das formas de convencimento adotadas na educação formal e em serviço. Melhor dizendo, adoção de abordagens que privilegiem a adoção de boas práticas não restritas à repetição de gestos, mas à sua incorporação enquanto valor.

De um segundo discurso médico, depreendemos, em um sentido diferente do primeiro, que os médicos não estão seguros de que estejam se protegendo ou sendo protegidos de forma eficaz. Convivem, no cenário hospitalar, com os riscos e exercitam seu ofício num ambiente de incertezas. 
Idéia Central - A relativa proteção, dependente das condições de infra-estrutura do hospital, da negligência do profissional e da falta de políticas específicas.

\section{DSC dos médicos}

A proteção é uma proteção relativa. A que a gente aprendeu na escola, acho que não tem. Acho que tem que melhorar muito. No caso, tomamos vacina, né. As três doses para a hepatite B. Procura-se usar luvas mais grossas até em prejuizo do próprio tato, que a gente perde um pouquinho, às vezes calça-se até duas luvas, mas nem sempre o uso de luvas é uma medida eficiente. A máscara também não é. Essa máscara que a gente usa não é apropriada. A gente vê que tem falhas. Observa-se, ainda, que muita gente não tem nem mesmo esses cuidados. Na verdade, uso meus óculos de grau e luvas, mas acontece dela furar. Usamos luvas recicláveis. Cada vez que você recicla essa luva, a porosidade e a elasticidade vai se modificando. Tem a falta de material para urgências. Facilitamos um pouco também. Pega um doente aqui, manipula, o doente chega ali, cheio de secreção e tal, a gente manipula, às vezes pega, não enluva as mãos. É um vicio, um mau vicio. Muitas vezes não se consegue diferenciar aquela paciente que está com doença infectocontagiosa, daquela que não está. Não há um screnning para a AIDS. O próprio governo deveria ter um trabalho na midia, uma politica, fazer uma coisa mais..., como ele fez, tem feito ultimamente em termos de pegar AIDS e tal. Tudo deveria ser diferente, até financeiramente. Os médicos, os auxiliares de enfermagem, saem do trabalho e vão para outro serviço. Então começa a ter descaso no atendimento. A gente tenta se proteger, mas está na mão de Deus.

Entrevistados 1,2,4,6,7,8,9,13,20.

Dos discursos médicos, talvez esse seja o que mais bem traduza o quadro da situação dos profissionais, em meio à realidade hospitalar, no que toca à sua proteção (ou desproteção), vez que sintetiza vários aspectos envolvidos na problemática da biossegurança.

O primeiro deles é concernente ao sentimento de uma proteção relativa, face à precariedade das objetivas condições de trabalho das instituições nas quais atuam. 
Nem sempre se dispõe de materiais de proteção e, quando esses são disponibilizados, não são de boa qualidade. Um segundo tema é o de que junta-se à essa precariedade, um certo descompasso no uso de regras que visam não somente à proteção do paciente sob sua responsabilidade profissional, mas também dos cuidados consigo próprio durante o desenvolvimento de suas atividades. Esse último tema é traduzido nas palavras dos entrevistados como "um mau vicio" ou, de outro modo, na descrição da própria prática "Pega um doente aqui, manipula, o doente chega ali cheio de secreção, às vezes pega, não enluva as mãos".

Esse retrato talvez encontre ressonância com o que afirma WAGENNAR (1990), que refere, ainda que debatendo especificamente sobre a ocorrência de acidentes de trabalho, que os profissionais encontram-se sob risco e isso não implica que eles estejam sendo levados a lhes dar atenção ou ter consciência à respeito.

Conquanto haja variáveis pessoais inerentes, são colocados em situações de risco pelas organizações. Assim, os acidentes que porventura acontecem não podem ser atribuídos à não aceitação ou percepção consciente do risco. Pelo contrário, as ocorrências são frutos de um processo decisório, em que o risco é falsamente omitido, subestimado ou simplesmente aceito. Consequentemente, conclui o autor, as ações de promoção e controle devem estar dirigidas não às possíveis vítimas, mas sim àqueles que nas organizações e na sociedade tomam decisões que vão criar situações em que as "rotinas" acabam tornando-se inseguras.

Outro aspecto que emerge do discurso médico diz respeito à problemática mais macro, que também corrobora para a composição do quadro supramencionado e relaciona-se às políticas de remuneração pelos serviços profissionais. Essas políticas, na ótica dos entrevistados, os afastam de um exercício mais condigno, trazendo conseqüências inclusive para a adoção de medidas de proteção pessoal.

O discurso ressalta que os profissionais têm quase que invariavelmente vários vinculos institucionais. Tal assunto é largamente discutido pela literatura e se assenta, no caso específico do médico, sobre os modos de ascensão e manutenção de 
um certo padrão de vida, com base na quantidade de atendimentos/procedimentos, forma preponderante de organização do trabalho no hospital (LACERDA 2000).

Conseqüentemente, depreende-se do discurso, é possível que os profissionais apresentem-se apressados, cansados, desatentos e, por que não, desmotivados. Conjunção de fatores que pode impelir à prática de auto-proteção mais descuidada e que não é desconsiderada no imaginário médico no que toca ao proteger-se.

Um último aspecto do discurso, refere-se ao imaginário da importância da não realização de triagens sorológicas para HIV de pacientes, enquanto elemento adjuvante no cenário da desproteção durante o desenvolvimento de atividades profissionais no hospital, aqui expresso: "Muitas vezes não se consegue diferenciar aquela paciente que está com doença infecto-contagiosa, daquela que não está. Não há um screening para a AIDS. "

A esse respeito, cabe-nos citar que reconhecer, através de provas sorológicas, infectados pelo vírus HIV é hoje providência continuamente em foco, envolvendo muitos aspectos relacionados com polêmicas éticas, legais, cientificas e políticas. Subsiste, todavia, a discussão quanto à serventia de se testar todos os pacientes admitidos num hospital, como meio apropriado de orientação das diretrizes de controle da infecção em pauta. No que se refere ao uso do exame como medida profilática ao exercicio das atividades dos profissionais de saúde junto aos doentes, constitui-se completamente descabida ainda que constitutiva do imaginário profissional. Primeiro, porque existem as precauções universais/padrão que devem ser utilizadas para o manejo de todos os pacientes independentemente de seus diagnósticos e, depois, porque não há evidências concretas de que a ciência da situação de infecção pelo HIV reduza a incidência de acidentes para a equipe multidisciplinar. (CHOTET et al. 1993, citado por CHOHFI et al. 1995, p.57).

Por último, porque seja pela questão ética, emocional, social ou mesmo científica, não se justifica a testagem compulsória (BRASIL 1993). O próprio Conselho Federal de Medicina, sobre o mesmo assunto também se manifesta contrário: "É vedada a realização compulsória de sorologia para HIV, em especial, como condição 
necessária à internação hospitalar, pré- operatório, [...]" (BRASIL 1993). Por outro lado, o mesmo conselho dispõe: "As instituições deverão propiciar ao médico e demais membros da equipe de saúde condições dignas para o exercício da profissão, o que envolve, entre outros fatores, recursos para sua proteção contra a infecção, com base nos conhecimentos disponiveis a respeito" (BRASIL 1993).

Do exposto percebemos um descompasso entre o que pensam os profissionais, por estarem eles submetidos às agruras do dia-a-dia, e o que manda a ética .

Estudo conduzido por CHOHFI et al (1995)com cirurgiões, demonstra resultados que se coadunam com o discurso médico aqui apresentado sobre a representação social de que a realização de testagem sorológica dos pacientes atuaria como meio eficaz de proteção ocupacional contra o vírus da AIDS. Os autores detectaram que $80,6 \%$ de mais de trezentos médicos entrevistados, de vários níveis de formação, declararam-se favoráveis à prática do exame em todos os pacientes candidatos à cirurgia. Complementam os pesquisadores que alguns cirurgiões que defendem o exame sistemático, justificam sua posição afirmando que os que argumentam contra o teste são clínicos que correm pouco ou nenhum risco, enquanto eles, os cirurgiões, encontram-se nas "trincheiras".

Os mesmos profissionais defendem ainda, ressaltam os autores, que as precauções universais/padrão, são consideradas adequadas apenas na teoria, mas os comportamentos se modificam nas salas de operação, quando o paciente é sabidamente HIV positivo.

Não podemos, contudo, nos esquecer, e aí concordamos com CHOHFI et al que além dos aspectos legais e morais que depõem contra o exame sistemático há ainda o aspecto prático que esta prática pode arremeter, a exemplo dos resultados negativos, na eventualidade de o paciente encontrar-se na denominada janela imunológica. Parece-nos que não seria demais supor que a posse de um resultado negativo poderá conferir à equipe uma sensação de segurança e, eventualmente, lacunas no emprego de medidas de auto- proteção. 
Por fim, voltando aos discursos aqui objeto de estudo, trazemos as falas daqueles que referem não se proteger rotineiramente, ou porque o seu trabalho é desenvolvido em instituição desprovida de recursos, ou porque se entende a adoção de medidas de proteção como distanciamento do paciente, ou porque vinculam a necessidade de proteção apenas ao trato com pacientes sabidamente portadores de doenças infecciosas, como a AIDS, mais uma vez, por exemplo.

Idéia central - A proteção não rotineira, dependente do tipo de paciente

\section{DSC dos médicos}

Normalmente não me protejo. Quando você sabe que o paciente é um aidético e tal, você põe, às vezes, duas luvas, você toma uma precaução, porque podemos nos acidentar numa operação. É a proteção que a gente faz. Proteção assim com material técnico não, porque é um hospital pobre, então se toma os cuidados higiênicos normais, de lavar as mãos. Basicamente só isso, mas distanciamento do paciente, não.

Entrevistados 15,16

Evidentemente que não se trata, esse discurso, de uma sintese que representa uma maioria, pelo menos considerando-se os profissionais aqui entrevistados. Não deixa, contudo, de ser relevante o registro dessa tipologia de sentimento. Primeiro, porque se percebe uma tendência de não se valorar a própria proteção por parte de alguns profissionais, conforme pode ilustrar a frase inicial do discurso "Normalmente não me protejo", ou seja o "normal" é não se proteger. Se aperceber disso nos parece de valia, quando da formulação e implementação de medidas que intentem modificações de comportamentos na prática assistencial. Segundo, porque se depreende que, ao contrário do que as pessoas e grupos imbuídos da elaboração de normas possam estar pensando ou até não se dando conta, alguns profissionais julgam as medidas de auto proteção, e aqui certamente elas se concentram no imaginário apreendido, mais no uso de equipamentos de proteção, que o seu emprego funcionaria como um "distanciamento" do paciente, o que contrariaria princípios médicos. A frase "mas distanciamento do paciente não" nos parece sintomática.. 
Por outro lado, paradoxalmente, o mesmo discurso que traz a questão do suposto distanciamento conferido pela utilização de medidas de auto proteção quando do contato com pacientes é o mesmo que alberga, salvo viés na sua elaboração, o sentido de que cuidados adicionais tenham que ser tomados frente ao conhecimento do diagnóstico do paciente, sobretudo da AIDS, o que denota que os princípios das tão ressaltadas precauções universais/padrão não fazem ainda parte do imaginário da totalidade dos profissionais.

Escapa ainda do discurso uma certa complacência com as condições hospitalares, que, de alguma forma, justificaria prescindir da adoção de medidas de proteção profissional, não obstante a relevante lembrança da importância de medidas higiênicas e o destaque para a lavagem das mãos que nunca é demais ressaltar faz-se digna de nota: "Trata-se de um hospital pobre". Levantamos, então, a questão: Os profissionais vêem como justa a questão de as instituições, por serem supostamente pobres, funcionarem sem o que se considera como minimo de proteção? $\mathrm{Ou}$, esse mínimo há que ser balizado de acordo com as condições do hospital? No que se constitui esse mínimo para o profissional?

Por outro lado, conforme já citado, nos parece que a acepção de proteção, por parte dos entrevistados, restringe-se praticamente à idéia daquela conferida pelos equipamentos de proteção individual. Talvez por um viés da questão levantada, ou possivelmente, pela força exercida por esses equipamentos no imaginário dos profissionais faz-se menção nos discursos apreendidos apenas uma única vez à proteção conferida pelas vacinas disponíveis, como a da hepatite $\mathrm{B}$, por exemplo, e nenhuma àquela auferida pelas conseqüências da triagem de pacientes com quadros compativeis com doenças transmissíveis e instituição precoce de isolamento e tratamento, haja vista o exemplo da tuberculose.

Não seria demasiado repetir que a prevenção e o controle da infecção pelo vírus da hepatite B, no ambiente hospitalar, baseiam-se na adoção de medidas de precauções universais/padrão, que demandam o uso de EPIs, e na vacinação dos profissionais de saúde. 
Para citar a importância dessas medidas, vale referirmos que estima-se que a incidência anual de HBV em profissionais de saúde nos Estados Unidos tenha declinado de 12.000 casos em meados da década de 80, para, aproximadamente, 8.700 casos no inicio da década de 90 (HADLER 1990). Nos casos desta infecção esse declínio tem sido atribuído à introdução da vacina contra a hepatite B, em 1982; a instituição das precauções universais, em 1985; a utilização da profilaxia pósexposição; e, em situações especiais, à triagem sorológica dos pacientes (ROZEMBAUM 1998).

Diversos estudos americanos de soroprevalência realizados antes da disponibilidade da vacina demonstravam que os profissionais de saúde apresentavam taxas de prevalência de infecção pregressa ou atual pelo HBV duas a cinco vezes maiores que a população geral (ROZEMBAUM 1998). A incidência de novos casos de hepatite entre profissionais da saúde susceptíveis ocorriam na taxa de $1 \%$ ao ano, para aqueles com exposição freqüente ao sangue (GIBAS et al. 1992).

Em nações desenvolvidas, os profissionais que exercem suas atividades em hospitais localizados na região urbana, em unidades de assistência terciária, com unidades de hemodiálise, apresentam maior risco de infecção pelo HBV. Tal risco provavelmente se relaciona com a maior exposição ao sangue e à maior prevalência de HBV entre os pacientes aí atendidos.

Em países em desenvolvimento, por outro lado, o risco de infecção pelo mesmo vírus não é uniforme e varia de acordo com a nação, região geográfica, nivel sócioeconômico, dentre outras. Nas áreas de endemicidade moderada e elevada, a maior prevalência de pacientes carreadores de HBV implica em maior risco ocupacional por parte dos profissionais da saúde susceptiveis (ROZEMBAUM 1998).

Ainda que o fulcro de nosso estudo sejam os discursos emitidos pelos profissionais, e que neles não se ressaltam as vacinas, possivelmente até porque elas não se constituam em repertório importante dos profissionais relativo à sua proteção, mesmo assim, nos parece relevante registrar estudos que vêm sendo publicados acerca da aderência dos profissionais de saúde ao imunobiológico em pauta. Em 
certa medida, voltando-nos aos discursos, pode-se supor que a pouca ênfase ao tema pelos médicos e, como veremos adiante também pelas outras categorias profissionais entrevistadas, se relacione à relativo descrédito à proteção do imunobiológico, possivelmente até relacionado ao imaginário da compreensão da vacina enquanto de destinação infantil ou ainda, que os imaginários dos profissionais tendam mais para o registro de ações mais palpáveis do dia-a-dia, como o uso de apetrechos de proteção, ou em última instância, o sentimento de que a vacina não cobre situações, em tese, para eles próprios mais preocupantes, haja vista o caso da AIDS. Essas últimas reflexões não podem, absolutamente, ser entendidas como abstraídas dos dados da pesquisa, mas tão somente de suposições.

Tomemos, então, alguns dados bibliográficos que tratam da aderência por parte dos profissionais à vacinação contra a hepatite $B$ e que levem em conta de alguma forma a valorização do imunobiológico enquanto medida de proteção.

Estudo de GYAWALI et al (1998), por exemplo, demonstra , dentre profissionais acidentados com materiais pérfuro-cortantes, em hospital londrino, em trabalho já citado no presente estudo, uma taxa de trabalhadores previamente vacinados para hepatite $\mathrm{B}$ de $78 \%$ e um índice de apenas $61 \%$ do staff com ciência de sua autoproteção contra o vírus por ocasião do acidente. MIRANDA et al. (1993), em outro tipo de trabalho, realizado em hospital de Santa Catarina, Brasil, com 123 profissionais da saúde, detectaram recusa à vacina por parte de $23(18,69 \%)$ dos indivíduos.

FERRAZ et al. (1991), em contrapartida pesquisando a aderência de profissionais de análises clínicas, observou índice de aceitação das três doses por $87,2 \%$ de 252 indivíduos considerados susceptíveis à doença. PAGLIARI e MELO (1997), por outro lado, ao investigar a cobertura da vacinação dentre estudantes de odontologia, observaram que de um universo de 384 alunos, apenas $22(5,72 \%)$ tomaram as três doses do imunobiológico, conforme o recomendado, antes do início de suas atividades junto aos pacientes. 
Também digno de nota foi a constatação de CHOHFI et al. (1995) que em pesquisa já citada neste trabalho, na qual detectou que mais de oitenta por cento de profissionais médicos por eles entrevistados declararam-se a favor da realização de triagem sorológica para HIV de todos pacientes candidatos à cirurgia, verificaram, paradoxalmente, que metade dos entrevistados, referiu nunca ter sido vacinada contra o vírus da hepatite $B$.

CARVALHO et al. (1998), em estudo transversal com 863 estudantes de Medicina, Odontologia e Enfermagem da UFPe verificaram, em relação à cobertura vacinal, que $49 \%$ dos entrevistados haviam sido vacinados (não houve referência, no entanto, ao número de doses recebidas), 32,4\% afirmaram não ter recebido nenhuma dose do medicamento e $18,5 \%$ não sabiam informar. As motivações para a não vacinação não foram, contudo, exploradas mas pode-se supor que a valorização da vacinação não seja universal. Note-se que quase $20 \%$ dos sujeitos desse último estudo não sabiam sequer informar se haviam ou não sido vacinados denotando o pouco impacto da medida nos seus respectivos imaginários.

LACERDA (2000), em contrapartida, em estudo acerca da exposição à sangue e outros fluidos em centros cirúrgicos nacionais, verificou que $33 \%$ dos profissionais pesquisados relacionaram a vacinação como o recurso mais importante para a prevenção de agravos ocupacionais relativos a agentes biológicos nas suas atividades. Mais, ainda, foi o recurso dos mais citados pelos mesmos profissionais (11\%) para o mesmo assunto, resultados considerados pela autora como expressivos e indicativos de tendência desses à busca, de segurança definitiva e imediata conferida pela vacinação.

O mesmo estudo revela, entretanto, que é também expressiva a importância atribuída pelos profissionais ao conhecimento das informações prévias sobre as condições infecciosas dos pacientes, através do seu histórico $(14,23 \%$ de referências como o item mais importante para prevenção de riscos biológicos relacionados a sangue e fluidos corpóreos) e através de exames diagnósticos (7,69\%). Observemos que esses percentuais somam $21,92 \%$ das referências, conferindo ao item em pauta o segundo lugar em grau de importância para os profissionais. 
Notemos, contudo, que quando se trata de situar os recursos mais citados pelos profissionais, se somados, analogamente, os dois subitens supra mencionados sob uma única denominação, qual seja conhecimento das condições prévias dos pacientes, esse mostra-se mais freqüente que a própria referência às vacinas com a percentagem de $15 \%$ contra os $11 \%$, conforme citado. Embora as diferenças não se constituam, aparentemente, tão grandes, isso pode demonstrar, em certa medida, que a importância atribuída à vacinação pelos profissionais talvez ainda não esteja num patamar que se possa considerar com o destaque compatível à sua relevância, mesmo em estudo com questões objetivas.

De outra parte, a não referência, nos discursos médicos objetos desse trabalho, à triagem precoce e instituição de medidas apropriadas frente a pacientes com quadro indicativo de tuberculose, enquanto medida de proteção para contaminação/contágio nos hospitais, possivelmente ocorra em função de não ser fonte de maiores preocupações a problemática da doença, no imaginário dos profissionais, enquanto risco ocupacional.

Cabe citar, no entanto, que parcela não desprezível dos entrevistados constituiu-se de médicos cirurgiões e obstetras, o que pode ter contribuído para o resultado. Nessas especialidades, por força da própria especificidade, o menor contato com problemas clínicos da natureza da tuberculose, por exemplo, é esperado. Em conseqüência, pode-se entender que determinados assuntos não se constituam em elementos de seu cotidiano e de seu discurso.

De outro lado, o debate sobre a transmissão nosocomial da tuberculose, desconsiderado o período pré-quimioterapia, é relativamente recente. Ressurgiu nos anos 90, motivado pelo aumento da prevalência de doenças nos países desenvolvidos (REZENDE 1996). A título de ilustração, entre 1985 e 1991, a incidência da tuberculose elevou-se de 24 a 34\% na Dinamarca, Itália e Suíça e 18,4\% nos Estados Unidos. Neste último, em algumas cidades, a incidência quase dobrou (MENZIES et al. 1995). Aumento este explicado pelo advento da AIDS, à imigração de indivíduos procedentes de países de alta prevalência e também a deterioração das instituições de 
cuidados à saúde (CDC 1989; DAUGHERTY et al. 1993), conforme já citado. A realidade em países subdesenvolvidos e em desenvolvimento é ainda mais grave.

No Brasil, nos últimos anos, têm sido notificados cerca de 80.000 casos de tuberculose anuais. Em 1994 foram registrados 75,759 casos, sendo 33.190 pulmonares bacilíferos. Esses dados colocam o país como o sétimo colocado em número de casos, depois da Índia, Indonésia, China, Filipinas e Paquistão (REZENDE 1996).

Concomitantemente, não obstante o estabelecimento de estritos critérios de hospitalização e a indicação do atendimento dos pacientes em ambulatórios da rede básica de saúde, esta meta não tem sido atingida e vários fatores tem contribuído para que o atendimento ao paciente com tuberculose retorne ao ambiente hospitalar.

Surtos de tuberculose têm sido descritos em hospitais. Esses surtos são associados, em sua maioria, ao retardo no diagnóstico e na instituição de isolamento respiratório por aerossóis, bem como ao atraso no reconhecimento da resistência à terapêutica (REZENDE 1996). Adicionalmente, altas taxas de conversão ao teste tuberculínico nos profissionais da saúde, também tem sido reportados mesmo em países desenvolvidos.

SEPKOWITZ (1994) relata, por exemplo, caso de hospital de Miami, no qual 21 (35\%), de 60 trabalhadores, tiveram conversão tuberculínica, depois de trabalharem em unidade onde um caso índice de tuberculose ficou internado por 57 horas, e surto ocorrido em 1983, quando um paciente ficou 4 horas em uma unidade de emergência - ocorreram onze conversões tuberculínicas em 112 trabalhadores, cinco dos quais desenvolveram tuberculose ativa.

No Brasil, dados sobre prevalência de infecção e da doença em profissionais são escassos, apesar da questão ter sido retomada nos últimos anos (REZENDE 1996).

BALEY (1990), em estudo realizado no Hospital Universitário de Londrina demonstrou taxa de tuberculose 3,6 vezes maior nos profissionais que na população em geral. REZENDE (1996), em Hospital Universitário de Campinas, chegou à 
prevalência geral de infecção tuberculosa de 57,9\% em profissionais da enfermagem. Em grupo considerado como de alta exposição à tuberculose, a taxa foi de $76,4 \%$ e, entre funcionários com menor contato com a doença (funcionários da manutenção), a taxa chegou a 61,9\%, ambas superiores à da população geral na América Latina e Brasil.

Conquanto o risco de transmissão da tuberculose para os profissionais de saúde varie consideravelmente entre as várias instituições, haja vista a prevalência da doença na comunidade, o tipo de clientela e o número de doentes atendidos anualmente, os pesquisadores, tanto os nacionais quanto os estrangeiros, são unânimes em afirmar que contribuem para o agravamento da questão da transmissão intra-hospitalar da infecção e, conseqüentemente, acometimento de profissionais da saúde, o atraso no diagnóstico seguido de pronta instituição da terapia. MENZIES et al. (1995), fazem referência à quatro coortes retrospectivas que tratam do assunto. Verificaram que houve atraso médio de seis dias no diagnóstico de 40 a $50 \%$ dos pacientes, o que resultou na exposição de 27 a 44 trabalhadores para cada paciente. Os atrasos foram atribuídos ao desconhecimento dos médicos sobre doença, apresentação de manifestações clínicas atípicas pelo doente e falta de infra-estrutura apropriada para a realização do diagnóstico.

SEPKOWITZ (1994), refere que depois de décadas de debate, torna-se claro que os trabalhadores da saúde encontram-se sob risco para o desenvolvimento da tuberculose, infecção e doença. Surpreendentemente, ressalta o autor, essa simples conclusão, tão óbvia agora, tenha levado décadas para ser compreendida. Afirma ainda que, embora o risco da infecção não chegue à zero, mesmo que instituídas todas as medidas preventivas, esse pode ser substancialmente minimizado se os serviços elegerem como prioridade o diagnóstico precoce e o isolamento das pessoas com suspeita da doença.

Lembramos que os serviços são constituídos de pessoas e que merece atenção, a não referência pelos médicos, à questão do diagnóstico precoce e pronta instituição da terapia e isolamento dos pacientes com quadro compativel com tuberculose, enquanto medida de proteção para eventual contaminação/contágio, embora de certa 
forma relativizada pela atualidade do assunto e, em menor instância, pelas especialidades médicas.

É possivel que essas medidas não façam parte do imaginário profissional também pelo fato da doença ter perdido o seu antigo status de doença grave e incapacitante, de alta transmissibilidade, na medida do acesso ao tratamento.

Ainda que não tenhamos encontrado na literatura trabalhos qualitativos acerca das representações médicas sobre a infecção/doença, estudo desenvolvido com outros profissionais de saúde pode ilustrar essa última possibilidade.

OLIVEIRA(1996), em pesquisa acerca das representações dos trabalhadores de enfermagem em hospital do Rio de Janeiro, também já aqui citado detectaram que poucos profissionais referiram medo de adoecer por tuberculose, embora a tenham representado como doença grave. A autora conclui, em vista dos conteúdos verbais expressos por seus interlocutores, que o temor é atenuado quando esses trazem à reflexão a existência da terapêutica eficaz. Destaca algumas falas para ilustrar sua assertiva: "É uma doença grave, se não tratada": "Tem cura, se for tratada a tempo e corretamente"; "É uma doença grave até certo ponto [...] mas no momento que você tem consciência dela e trate como deve ser, com medicação certa, é uma coisa controlável e fácil de tratar".

No que se refere ao discurso dos enfermeiros, nesse nosso estudo, posta a questão se protegem de contaminação/contágio nas atividades desenvolvidas no hospital, estes apresentam duas construções discursivas que se assemelham aos dois mais recorrentes repertórios médicos. Uma relativa à categoria da proteção como um hábito, na qual os profissionais trazem para si a responsabilidade de autoproteger-se e uma outra que expressa a tentativa de se proteger, intento esse limitado pelas condições de infra-estrutura do hospital. Vejamos, então, após o quadro síntese das idéias centrais, a primeira delas.

Quadro Síntese - Você se protege de contaminação e de contágio em suas atividades no hospital? (Profissionais enfermeiros) 
Idéias centrais

\begin{tabular}{|l|l|}
\hline A proteção como um hábito. & $\begin{array}{l}\text { A proteção relativa, dependente das condições de } \\
\text { infra-estrutura do hospital. }\end{array}$ \\
\hline
\end{tabular}

Idéia Central - A proteção como um hábito

\section{DSC dos enfermeiros}

Me protejo sempre. Me passo por chata porque não permito uma punção venosa sem o uso da lava. A gente tem que se proteger, a gente não sabe. Tem algumas coisas que eu me recuso a fazer. Já ouvi dizer deixe de frescura. Proteção com luvas, com máscaras, lavagem das mãos, todos os cuidados. A partir do momento que o paciente adentra a unidade de emergência, só o atendo depois de calçar luvas. Principios básicos a gente aprende que se quiser, a gente torna vicio mesmo. Para o nosso próprio bem.

Entrevistadas 2,4,7,8,9,10,13.

Chama-nos a atenção a consciência dos enfermeiros de que se protegem sempre, ainda que ocasionalmente em condições adversas. Condições essas, a julgar pelas falas, impostas algumas vezes pelos próprios colegas de trabalho. "Deixe de frescura" é sintomático. "Me passo por chata", igualmente. Depreendemos, assim, grosso modo, que a auto-proteção não é compreendida como uma rotina nas instituições, por todos os profissionais, o que explicaria as críticas àqueles que buscam maneiras de se precaverem contra eventuais riscos. Possivelmente aqueles que criticam não vêem tantos riscos nas atividades que estejam desenvolvendo. $\mathrm{E}$ isso poderia ocorrer por lapsos no conhecimento daquele que critica, mas também pelos exageros praticados por aqueles que são criticados.

Uma e outra situação merecem atenção, posto que podem influenciar na implementação de medidas que visem a melhora na adesão a medidas de autoproteção nos hospitais. De um lado, os profissionais que desconhecem os riscos, ou pelo menos sua magnitude, não se protegem e funcionam como exemplos negativos à aderência às medidas e, de outro, aqueles que podem estar a superestimar os riscos e a praticar a auto-proteção como um ritual desprovido de sentido, que pode ser caracterizado como "um exagero". Tomemos uma frase do discurso para ilustrar essa 
possibilidade: "a partir do momento que o paciente adentra a unidade de emergência, só o atendo depois de calçar as luvas".

Para LACERDA (2000), a universalização e massificação das precauções universais/padrão tem gerado, não raro, comportamentos ansiosos de proteção e, paradoxalmente, dificultado a devida tranqüilidade para realizar procedimentos técnicos adequados e seguros e inversão da relação meio-fim, criando, assim, até outros riscos iatrogênicos, além da contaminação da dupla via (trabalhador-cliente e cliente-trabalhador), como exemplos, mãos enluvadas sendo perfuradas durante instrumentação e punção. O resultado prático dessa falta de racionalização dos processos de trabalho, conclui a autora, já é amplamente conhecido: multiplicação e aquisição de barreiras de proteção e seu uso indiscriminado e nem sempre adequado aos fins a que se propõem, principalmente as luvas de procedimento.

Apreende-se, adicionalmente, do discurso, que a auto-proteção vincula-se ao seguimento de princípios básicos aprendidos provavelmente durante a formação profissional, sendo elemento bastante positivo. Bons princípios deveriam constituir o norte de toda formação que se quer da saúde. Princípio entendido, certamente, na acepção larga da palavra, e não num conjunto dogmático de ações.

No discurso dos enfermeiros, a exemplo do discurso médico, ao tratar da sua proteção, se dá ênfase ao uso de equipamentos de proteção individual. Mais uma vez é ressaltado o uso das luvas, apesar da referência às máscaras e lavagem das mãos. A ênfase no uso das luvas parece indicar mais uma vez, a preocupação com os agentes biológicos veiculados pelo sangue, o HIV e as hepatites, que têm como principais portas de entrada as mãos dos profissionais, através dos acidentes com materiais pérfuro-cortantes .

Os enfermeiros não fazem referência à aderência a vacinas, bem como a mecanismos outros que também conferem proteção aos profissionais atuantes em hospitais, como a triagem precoce de pacientes com quadro compativel com infecções e instituição de medidas específicas de isolamento. A acepção de proteção mostra-se, quase que invariavelmente, vinculada ao uso de equipamentos de proteção individual e o elenco 
de apetrechos é feito de forma difusa, tome-se por exemplo : "Proteção com luvas, com máscaras, lavagem das mãos, todos os cuidados".

De qualquer sorte, depreendemos, dos discursos, que medidas de auto-proteção são consideradas importantes pelos profissionais, o que vem ao encontro da literatura, que demonstra que, embora as aderências às medidas de proteção para agentes biológicos estejam muito distantes do que se poderia considerar como ideal, são os profissionais de enfermagem os que mais adotam os procedimentos dentro do recomendado (PITTET et al. 1999; SHARIR et al., 2001) e, ainda que há uma tendência de aumento de adesão às medidas preconizadas após procedimentos que visem maior conscientização.

SAGHAFI et al. (1992), por exemplo, em pesquisa realizada com enfermeiros em hospital universitário, com o objetivo de dimensionar a ocorrência de exposição cutânea à sangue em diferentes procedimentos, bem como as taxas de acidentes com agulhas e prevalência de lesões nas mãos, verificou que $42 \%$ das profissionais, de um total de 565 , expuseram-se ao sangue com as mãos desprotegidas. E ainda, através do exame direto das mãos de cinqüenta enfermeiros selecionados aleatoriamente detectaram que 57\% delas apresentavam lesões agudas ou crônicas. Um ano após a introdução das Precauções Universais no hospital, observaram redução de $27 \%$ da exposição ao sangue com as mãos desprotegidas, embora $46 \%$ das enfermeiras ainda mencionassem o não uso das luvas para procedimentos para os quais eram indicadas.

RAMSEY e GLENN (1996), em estudo desenvolvido com enfermeiros de instituições hospitalares do Tenessee - Estados Unidos, entre os anos de $1991 \mathrm{e}$ 1993, detectaram queda de ocorrência autoreportada de acidentes com agulha em $69 \%$, após a publicação das medidas relativas às precauções universais pela OSHA. Verificaram ainda que também a vacinação dos profissionais para a hepatite $B$ elevou-se significativamente a taxas de $61,4 \%$ para $82,5 \%$. Ressaltaram, contudo, as autoras, que a freqüência de exposição dos enfermeiros ao sangue, sem o uso de proteção, permanecia ainda alta e subnotificada. 
GODIN et al. (2000), em estudo desenvolvido com 156 enfermeiros atuantes em Hospital Regional no Canadá, acerca de aspectos determinantes da aderência às precauções universais, detectaram que das 105 profissionais que reportaram realização de punção venosa em determinado período circunscrito pela pesquisa, $38 \%$ aplicaram as precauções em 8 ou mais 10 pacientes, nos quais o procedimento foi realizado e $16 \%$ as aplicaram em todos os pacientes. As autoras chegaram à conclusão, dentre outras, que, em geral, as enfermeiras tem uma forte intenção de aderir às precauções. A decisão, contudo, de colocá-las em prática, relaciona-se grandemente à percepção de barreiras, aspectos subjetivos e sentimentos pessoais acerca das normas. Para elevar a aderência, asseveram as autoras, é necessário que a percepção dos obstáculos seja reduzida.

No que se refere aos sentimentos pessoais acerca das normas, as pesquisadoras afirmam que se trata mais de um aspecto de ordem, o qual denominam de moral. Ilustram sinteticamente o que puderam perceber da seguinte forma: "Se as enfermeiras acreditam que as pessoas, as quais elas têm em alta conta, como lideranças respeitadas no seu trabalho (colegas, supervisores, membros da $\mathrm{CCIH}$, pacientes bem informados, membros familiares e outros) ou no seu ambiente social, esperam delas a aderência às precauções, elas tendem a ser mais aderentes."

As autoras sugerem, face ao observado, que quando do desenvolvimento de intervenções que visem o incremento da aderência às práticas de auto-proteção, sejam considerados também esses aspectos. Obviamente, completam, que isso não será por si suficiente se as condições objetivas de trabalho também não sofrerem melhorias.

A problemática da indisponibilidade de infra-estrutura adequada no hospital é, coincidentemente, a temática do segundo discurso dos enfermeiros acerca da questão da proteção para agentes biológicos, em nosso estudo. Conforme já discutido quando da apresentação dos discursos médicos sobre sua proteção, assim como dos discursos sobre risco, a referência à força exercida pelo ambiente no emprego das medidas de auto-proteção mostra-se considerável. 
Idéia central - A proteção relativa, dependente das condições de infra-estrutura do hospital

\section{DSC dos enfermeiros}

A gente procura se proteger de acordo com o que se tem em mãos. Na verdade, só se protege entre aspas, com o uso das luvas, máscaras sempre que possivel. Outros equipamentos de proteção individual não se dispãe. Não se tem aventais, capas. É a luva mesmo, quando dá tempo. Porque, às vezes, nem luva a gente está usando. Pronto socorro é um negócio complicado, a questão da biossegurança, por causa do tempo e também por problemas nos materiais. Luva sem talco, por exemplo, não entra na mão de ninguém. Ninguém consegue calçar. Ai tira a luva, vai sem luva mesmo. De médico à técnico de enfermagem.Eu tento sempre estar de máscara, mas aqui dentro é tão quente. Por outro lado, às vezes, a gente também se passa.

Entrevistadas $1,3,5,6,11,12$.

O discurso é claro ao desvelar que embora haja um suposto esforço dos profissionais para se autoprotegerem, esse esforço é frustrado pela falta de condições infra estruturais do hospital, ou seja, emprestando-se as próprias palavras do discurso emitido "Só se protege(m) entre aspas". Refere que não se dispõe de equipamentos básicos como aventais, capas e óculos para a lida com situações elencadas pelos nossos próprios interlocutores e pela literatura especializada, como das mais problemáticas, em especial pelo contato com sangue e secreções, as unidades de emergência, por exemplo. Além da falta mesma de alguns paramentos, o discurso indica que ocorre a oferta descontinuada de outros: "máscaras sempre que possivel", é ilustrativo.

Acresce-se à carência de materiais e equipamentos, o problema do escasso número de profissionais para o atendimento dos pacientes ou pelo menos problemas relacionados ao processo de trabalho, implícitos no fragmento " [...] quando dá tempo". E, como elemento adjuvante, que revela as mazelas administrativas que acabam por interferir na tentativa de autoproteger-se dos profissionais, figura a oferta de equipamentos de má qualidade - "Luva sem talco, não entra na mão de ninguém". Ou seja, quando os equipamentos são oferecidos estes ainda são 
disponibilizados de maneira a dificultar ou até mesmo impedir o seu uso. - "ninguém consegue calçar, ai tira a luva, vai sem luva mesmo".

Evidentemente que, num ambiente com esse estado de coisas, algumas vezes até se dispondo do material mínimo necessário, ele acaba não sendo utilizado - "às vezes a gente se passa". E as próprias iniciativas de se instituir medidas um pouco mais complexas, certamente são coibidas. Assim barreiras situacionais que se tornam crônicas, levam a crenças pessimistas e à baixa motivação para a adoção de comportamentos preventivos, conforme refere DELA COLETA (1995) citado por SOUZA (2001, p157).

A literatura que trata da aderência às medidas de auto-proteção pelos trabalhadores dos hospitais é bastante vasta, particularmente as internacionais, algumas delas já citadas no escopo deste estudo. Muitos artigos trazem a problemática da influência do ambiente na adesão às medidas. O cerne, todavia, dessa influência centra-se muito mais na gravidade do doente atendido, na emergência da situação, nos efeitos negativos dos sabões nas mãos dos profissionais, que os desestimulam a sua lavagem, no número de pias aquém do ideal, que desencorajam, de igual modo, a adesão, à contento, de procedimentos importantes, e outros dessa natureza, do que propriamente da falta real e inequívoca de equipamentos de proteção individual, o que pode ser explicado pelas diferentes realidades dos países e locais onde os estudos são realizados.

Também na literatura nacional que trata especificamente da biossegurança em hospitais brasileiros, a problemática das condições materiais não se apresenta, salvo exceções, assim tão contundentes quanto a apreendida dos discursos aqui analisados. Observemos, todavia, que os estudos, em sua maioria, são conduzidos principalmente em instituições localizadas nos grandes centros urbanos que, ainda que apresentando, em tese, mais riscos biológicos por sua própria natureza, devem apresentar condições infra-estruturais mais adequadas. Condições essas, entretanto, que certamente não devem corresponder à condição média hospitalar do país. De qualquer forma, limitações de infra estrutura são registradas. 
SOUZA (2001), por exemplo, em estudo sobre biossegurança em hospital universitário de Goiânia, abstraiu algumas falas dos enfermeiros entrevistados para explicar a ocorrência de acidentes com materiais pérfuro-cortantes na ausência de equipamentos de proteção individual, falas essas aqui transcritas:

"Nossa luva é de tamanho " $p$ " e quase sempre temos disponiveis para uso apenas luvas " $M$ " $e$ " $G$ ";

"Tentamos mudar o recipiente (coletor de agulhas), mas não tínhamos recursos para isso";

"A CCIH padronizou o uso de óculos, mas ainda não conseguimos disponibilizá-los para todos".

ALMEIDA FILHO (1999), em trabalho entitulado "A liberdade e o compromisso no agir do enfermeiro frente à situação de risco de contaminação", desenvolvido no setor de emergências de hospital público de grande porte da cidade do Rio de Janeiro, registrou depoimentos dos enfermeiros sobre o problema da carência de equipamentos de proteção individual: "Os únicos materiais que nós temos, fornecidos pelo hospital, são as luvas e as máscaras, ainda assim essa última é do tipo comum, não possui filtro adequado, para maior proteção. Outros materiais como óculos, quem tem é porque adquiriu por conta própria". "No serviço público é bom enfatizar, que se está sempre muito exposto. O material que nos é fornecido para trabalhar é insuficiente para se manter as normas de biossegurança [...] e de péssima qualidade".

SOUZA (1999), em investigação empreendida em cinco hospitais da cidade de São Paulo também acerca de acidentes com materiais pérfuro-cortantes, retrata, a problemática da infra-estrutura no que se refere à carência de recursos humanos e à alta carga de trabalho imposta aos profissionais de enfermagem em hospitais públicos e também privados.

Do seu trabalho compilamos, igualmente, alguns depoimentos, a título de ilustração:

“[...] No dia que eu fui acidentada, faltaram muitos funcionários, dai, a gente fica só em dois, um na medicação e o outro nos cuidados, fazendo outras coisas. A 
enfermaria estava lotada, cheia de pacientes e tinha esse com HIV, quando fui fazer uma medicação, me piquei. Mas é isso, excesso de serviço [...]";

"[...] Estava agitado o plantão e isso atrapalha psicologicamente, você acaba executando muitas tarefas e sobrecarrega o funcionário";

"O problema é o excesso de serviço, às vezes você dá plantão de 12 horas e, quando chega no final, que você já deu tudo de si, bem cansada, acontece o acidente";

"[...] Foi falta de pessoal, a gente tem que acelerar, trabalhar rapidinho, senão não dá tempo de fazer as coisas, e acontece esse tipo de acidente, ai falta a atenção por falta de funcionário";

"No meu caso não foi falta de orientação nem de material, foi estresse por ter muito serviço e poucos funcionários".

No que tange à carência de recursos materiais, a mesma autora encontrou referência a problemas nos hospitais públicos e em setores dos hospitais privados destinados ao atendimento de pacientes cujas fontes de pagamento pelo serviços eram recursos provenientes do SUS. Nos hospitais públicos, as citações à falta de material, conforme registra a pesquisadora, centraram-se particularmente nos óculos de proteção, dado de relativa confluência com os nossos, vez que embora nestes últimos, os discursos apresentem um sortimento maior de carências materiais, há também o foco sobre esses equipamentos, considerados inexistentes nas instituições.

As mensagens extraídas do trabalho de SOUZA (1999), são as a seguir apresentadas.

"acho que a única coisa que falta são os óculos";

" na enfermaria não tem óculos de proteção, só na UTI";

"todo material é descartável, mas às vezes falta luva e você tem que economizar",

“às vezes falta luva, mas depois aparece, é por causa da greve". (de depoente de hospital público, em greve à época da realização da entrevista). 
Sobre a realidade do hospital privado nos setores de atendimento aos pacientes do SUS, conforme dados de SOUZA (1999), podemos ilustrar conforme abaixo:

"Seringa descartável só para particular e convênio, no setor de pacientes do SUS, as seringas são de vidro e as luvas são re-aproveitadas. Apenas para pacientes internados no isolamento com hepatite, HIV ou outra doença infecciosa, tem tudo separado";

"No setor onde trabalho, as luvas são lavadas, só nos casos de HIV, hepatite, eles dão as descartáveis":

"Como a seringa é de vidro, não tem jeito, você tem que reencapar a agulha para poder desconectá-la e desprezá-la".

Essas últimas narrativas ilustram uma situação que, permite-nos dizer, resvala-se na ética e nos próprios princípios de equidade norteadores do SUS, quando explicitam a existência de diferenciação na prestação de um mesmo serviço àqueles que pagam diretamente ou através de seus convênios privados, e àqueles que remuneram indiretamente através dos recursos provenientes dos contribuintes. Observemos que, muito embora não tenhamos a pretensão de abrir aqui parêntese para discussão mais aprofundada do assunto, não se trata, no caso em apreço, apenas de prestar um serviço diferenciado, de maior conforto para o primeiro grupo, mas de colocar em risco a saúde do segundo, bem como daqueles que deles tratam, o que se constitui em um assunto também atinente à biossegurança.

De igual modo, os discursos dos enfermeiros deste presente trabalho podem estar igualmente a desvelar um problema ético, à medida que desenham uma prestação de assistência à saúde sem a devida segurança. Não apenas um problema de ordem ética, mas também de ordem legal, se configurado o descumprimento das normas regulamentares que versam sobre as obrigações dos empregadores acerca da disponibilização dos equipamentos de proteção individual aos trabalhadores.

Se, hipoteticamente, ao contrário do que pensam os enfermeiros, as instituições acreditam que vêm oferecendo as minimas condições de infra-estrutura para a auto- 
proteção dos profissionais e esses não estão se dando conta que estariam suficientemente protegidos, há um problema de falta de confluência entre as partes. Até mesmo essa falta de confluência prejudica sobremaneira a implementação de medidas a contento.

Ouvidos os auxiliares e técnicos de enfermagem, esses emitem, sobre sua proteção para agentes biológicos, quatro discursos. Os dois primeiros, ainda que com repertórios lingüísticos com alguma diferenciação, mostram-se coincidentes, em essência, com os discursos médicos e dos enfermeiros.

Quadro Sintese - Você se protege de contaminação e de contágio em suas atividades, no hospital? (Auxiliares e técnicos de enfermagem)

Idéias Centrais

\begin{tabular}{|c|c|c|c|}
\hline \begin{tabular}{|l} 
A proteção como \\
rotina de \\
com os trabalho, \\
disponiveis.
\end{tabular} & $\begin{array}{|lr|}\text { A relativa proteção, } \\
\text { dependente } & \text { das } \\
\text { condições de infra- } \\
\text { estrutura do hospital. }\end{array}$ & $\begin{array}{lr}\text { A } & \text { proteção } \\
\text { dependente } & \text { do } \\
\text { diagnóstico } & \text { do } \\
\text { paciente. } & \\
\end{array}$ & $\begin{array}{l}\text { A } \\
\text { desproteção. }\end{array}$ \\
\hline
\end{tabular}

O primeiro discurso, conforme visualizado no quadro acima, concerne ao cumprimento das normas e ao uso de equipamentos de proteção individual. Equipamentos esses, todavia, limitados praticamente às luvas, mais uma vez ressaltando-se a ênfase nos cuidados com o contato das mãos com sangue e secreções. 
Idéia central - A proteção como rotina de trabalho, com os recursos disponíveis

\section{DSC dos auxiliares e técnicos de enfermagem}

Procura-se usar todos os equipamentos que o hospital oferece e sempre as medidas de segurança, buscando sempre seguir as normas. Atenção é primordial para que não haja contaminação. A gente usa pelo menos o que a gente conhece: luvas. Vai dar banho em paciente, luvas. A gente coloca também uma capa. Dependendo do que está acontecendo com o paciente, a gente põe máscaras. Punção na veia, luva. Para todo procedimento que envolve contato com secreções do paciente, usamos tudo o que for necessário. Sempre, sempre, a luva. Não se faz nada sem usar uma luva e sem lavar as mãos. Mil vezes eu chego perto do paciente, eu lavo as minhas mãos. Todo o procedimento eu estou fazendo de luvas, só não sinais vitais, a não ser portador de HIV, que às vezes é muito comum desconectar o equipo e é bom evitar. Mas sempre de luva e máscara. Ah, a gente se protege, a gente pega uma agulha, quando a gente vai tirar a agulha da seringa,estando usada, a gente não vai pegar na agulha. A gente tem que desconectar aquele negócio da agulha, para poder tirar, para não se contaminar.Escalpe tem que tirar com o máximo de cuidado. E tudo tem um local para a gente colocar, nas caixinhas certas, de botar as coisas usadas, para jogar fora. Ai a gente não tem tempo de se contaminar. Geralmente já saio do posto, por causa das visitas ,já venho com luvas e máscaras. Se acontecer alguma coisa, já estou protegida. Para paciente com odor fétido, máscaras e algodão nas narinas.

Entrevistados 2,3,4,8,10,11,15,16,18,21,22,23,25,26,30,31,36,41.

Denota-se ainda uma acentuação na necessidade de cumprimento de normas, "sempre as medidas de segurança"; "buscando sempre seguir as normas"; "atenção é primordial", "não se faz nada sem usar uma luva e sem lavar as mãos". 
Toda essa ênfase, se de um lado pode indicar o quanto as normas são importantes no imaginário dos auxiliares e técnicos de enfermagem e o quanto isso pode contribuir para a adoção de medidas de auto-proteção, por outro, pode ilustrar o quanto de ações são empreendidas de forma irrefletida, porque simplesmente são normatizadas - "sempre, sempre a luva". "Não se faz nada sem usar uma luva e sem lavar as mãos". Não se negando a importância comprovada dessas medidas como proteção dos profissionais, há que se buscar que elas sejam empreendidas com a devida compreensão do risco envolvido nas diferentes ações na assistência aos pacientes, sob pena de serem reduzidas a obrigações destituídas de significado, trazendo conseqüências para as pessoas e organizações, essas últimas, sobretudo as relacionadas a custos financeiros.

A fala "Para o paciente com odor fétido, máscaras e algodão nas narinas", exemplifica alguma confusão entre o que deve ser medida de proteção eficaz e o uso arreflexivo de apetrechos. E se formos mais adiante, parece denotar inclusive distanciamento das noções básicas de contágio, de contaminação e de medidas eficazes, ou pelo menos fortemente indicadas como de proteção.

Nesse sentido, não seria redundante referir que a educação em serviço tem papel importante, na medida em que pode promover a desmistificação de alguns (des)conhecimentos já enraizados no imaginário de uma parte dos profissionais, como também o reforço à necessidade do cumprimento das regras, não de maneira pura e simples, mas de modo que os sujeitos as incorporem como valor e suas ações tenham, em conseqüência, sentido. Para ilustrar, tomemos as palavras de GARFIELD (1983), para o qual a alienação separa as conseqüências das atividades exercidas pelas pessoas de suas reais necessidades, intenções e controle.

O segundo discurso dos profissionais de nível médio de enfermagem discorre sobre a busca da proteção como uma tentativa que se frustra na indisponibilidade de alguns EPIs, como, por exemplo, as máscaras, e na qualidade de outros: "a proteção não é bem segura não, porque a luva, quando a gente vai ver, está furada". E ainda nas intercorrências que os pegam desprevenidos. 
Idéia central - A relativa proteção, dependente das condições de infra-estrutura do hospital

\section{DSC dos auxiliares e técnicos de enfermagem}

Tenta-se proteger ao máximo, usando pelo menos o que conhecemos. O que a
gente pode evitar, a gente tenta evitar. A gente se protege assim: luvas, máscara
mesmo é dificil. Ah, não tem, vai chegar. Nisso a gente tem que fazer, dar os
cuidados. A proteção não é bem segura não, porque a luva, quando a gente vai
ver, está furada. Se proteger a gente se protege, mas acontecem intercorrências e
às vezes se está despreparado.Se protege no que pode, calça luvas, máscara. Tem
vezes que a gente recebe o paciente e não sabe a doença dele. Aí já é tarde. A
gente já fez o que tinha que ser feito sem proteção. Porque você se protege de luva
mas e nesse caso? De você se furar?
Entrevistados $1,5,17,19,35,38,40$.

Abstraímos do discurso que pairam dúvidas sobre se o que vêm usando, ou seja, o que conhecem, seria suficiente para conferir a proteção desejável. O "usando" reforça sobremaneira a importância atribuída aos EPIs pelos profissionais.

Ressaltamos, por outro lado, a desconfiança tanto nos aspectos organizacionais das instituições, revelada numa simples e flagrante fala quando se refere à falta de materiais: "Ah, não tem, vai chegar", bem como a própria descrença na real efetividade dos equipamentos, notadamente, conforme relato, das luvas, que constitui-se no que eles bem conhecem e que, às vezes, aparecem danificadas pelo uso e re-uso.

Permitimo-nos inferir que também o período "Se proteger, a gente se protege, mas acontecem intercorrências e às vezes se está despreparado" pode estar a indicar que, para esses profissionais, a proteção não é vista como parte indissociável do trabalho, mas algo a ser acrescentado na medida do contexto. Em suma, a depender do diagnóstico do paciente, do corre-corre do plantão, da disponibilidade de material, enfim, do momento. 
Essa não se mostra uma realidade circunscrita, mas certamente mais abrangente. Pesquisa de LINS (1998), pode ilustrar nossa inferência, com uma frase muito simples, compilada do discurso de uma auxiliar de enfermagem, durante entrevista, e que retrata bem a problemática: "Olha, às vezes não dá nem para você lavar as mãos".

Um terceiro discurso dos auxiliares e técnicos de enfermagem torna visível, assim como depreendido em um dos discursos médicos, a mentalidade do emprego de medidas de proteção adstrito ao conhecimento do diagnóstico do paciente, em flagrante descumprimento ao que preconiza as precauções universais/padrão, que postula cuidados com sangue e secreções de todos os pacientes independentemente de diagnóstico firmado ou presumido.

Idéia central - A proteção dependente do diagnóstico/situação do paciente.

\section{DSC dos auxiliares e técnicos de enfermagem}

Quando a gente sabe o diagnóstico do paciente, a gente se protege. Agora quando não sabe [...]. Quando o diagnóstico sai depois [...], ai fica quase impossivel de se proteger. Em casos de infecções, a gente põe uma luva, uma máscara, uma capa, procura fazer uma assepsia melhor.Quando uma contaminação assim, me protejo com uma roupa especial. Quando o paciente está de hepatite e outras coisas, aí tem que usar luva, máscara, tudo direitinho.Nas enfermarias de pacientes com condilomas a gente entra com capas. Para pacientes aidéticos, a gente tem o cuidadinho de colocar nossas luvas, de colocar nossa máscara.Eu trabalho assim se eu sei que ele é aidético.

Procura-se também falar o mínimo com ele, ter o máximo de cuidado com o acesso venoso dele. Jamais, sabendo que ele é assim, se punciona a sua veia sem colocar luva. Coloco a luva direitinho.

Entrevistados 9,27,28,29,34,39.

Esses resultados divergem dos achados de SOUZA (2001), que detectou que 100\% da amostra dos auxiliares de enfermagem de hospital de ensino de Goiás, 
reconheciam a indicação das precauções padrão/universais para serem aplicadas ao atendimento de todos os pacientes, independentemente do diagnóstico.

Cabe a referência, todavia, que os estudos têm natureza diferente. No estudo de SOUZA (2001), a questão é colocada de forma direta e fechada, o que a permitiu captar objetivamente as respostas afirmativas. Em nosso estudo, de cunho qualitativo, depreendemos de forma indireta e dedutiva, que as precauções padrão não estão tão incorporadas no imaginário dos sujeitos da pesquisa, quanto se quer acreditar. Esse tipo de achado permite mostrar a importância da utilização de diferentes metodologias de abordagem até para um mesmo objeto de investigação. Não queremos negar aqui, todavia, a possibilidade de que os profissionais por nós entrevistados não estejam menos instruidos acerca das citadas precauções, se comparados com os resultados de SOUZA (2001), mas aventar a hipótese de que se tivéssemos utilizado uma metodologia diretiva na abordagem da questão, certamente a sutil constatação que os profissionais se "cuidam" mais quando conhecido o diagnóstico do paciente, talvez não tivesse sido revelada.

Abstraímos ainda do discurso, que as medidas de auto-proteção são desprovidas de um direcionamento também para as precauções baseadas na transmissão, indicadas para pacientes comprovadamente infectados, ou suspeito de sê-lo, com patógenos altamente transmissíveis, conforme preconiza o $\mathrm{CDC}$ e os órgãos de referência nacional.

As afirmativas desvelam que os auxiliares e técnicos de enfermagem desconhecem ou pelo menos não conhecem com a profundidade requerida que, para cada grupo de doenças transmissíveis, recomenda-se o uso de um conjunto específico de precauções e barreiras. Dessa forma, podemos concluir, a partir dos dois fatores, o suposto descumprimento das precauções padrão e o desconhecimento das precauções baseadas na transmissão, podem, certamente, colaborar para o aumento inadvertido à exposição dos profissionais, a riscos biológicos.

Notemos ainda, nos discursos, a flagrante assistematização quando do elenco dos EPIs, dos quais são lançados mão e o primarismo na utilização de certos conceitos. 
"Em casos de infecções a gente põe uma luva, uma máscara, uma capa, procura fazer assepsia melhor";

"Quando o paciente está de hepatite e outras coisas, aí tem que usar luva, máscara, tudo direitinho";

Em meio a esse suposto desconhecimento, afloram práticas fora de propósito: "Para pacientes aidéticos, a gente tem o 'cuidadinho' de colocar nossas luvas (que em tese, para a mànipulação de sangue e secreções têm que ser utilizados para todos os pacientes), "de colocar nossa máscara" (?). "Procura-se também falar o mínimo com ele (?), ter o máximo de cuidado com o acesso venoso dele".

Essas afirmativas flagram a problemática da falta de preparo dos auxiliares e técnicos de enfermagem que acabam em redundar em comportamentos que geram riscos para si próprios e também ao confinamento desnecessário dos pacientes sabidamente portadores de doenças infecciosas a exemplo da AIDS. Dessa forma citamos HENDERSON (1995), que referem que os trabalhadores de saúde devem conhecer os riscos presentes no seu local de trabalho, bem como sua magnitude e receber educação e treinamento sobre medidas efetivas de controle e, ainda, dispor de instrumentos e dispositivos mais seguros para a execução de suas atividades e, acrescentamos, suporte teórico para não tornar as vidas dos pacientes ainda mais difíceis.

Observemos que, embora nossa análise busque dados qualitativos, não se pode deixar de registrar que não foram poucos os entrevistados que colaboraram com suas falas para a configuração desse discurso. Cabe ainda a ressalva de que tratam-se de falas espontâneas. É possível que se questões outras que enveredassem sobre suas práticas fossem postas, outros temas controversos emergissem .

Por último, o discurso daqueles que têm um sentimento de desproteção, porque não tem domínio sobre o acontecimento das coisas no hospital, conforme ilustra a frase aqui compilada: "Tem aquele caso de paciente que está na enfermaria, normalmente, quando o médico vai pedir o exame, está tuberculoso"; ou porque imagina não ter tempo de se proteger ou não tem disciplina para tal, de igual modo 
aqui descrito, "quando se vê, já estamos com a mão; já estamos fazendo isso " ou até mesmo, porque embora reconhecendo o que seria o correto, preocupam-se com os custos adicionais ao hospital se forem empregados determinados equipamentos para sua própria proteção, abstendo, desse modo, de se protegerem, colocando nos céus os seus destinos: "só o Senhor Jesus que protege".

Idéia central - A desproteção

\section{DSC dos auxiliares e técnicos de enfermagem}

A gente está exposto mesmo. Procura se proteger, mas de alguma forma está desprotegido.E também não só a luva adianta. Mesmo porque é uma emergência Você está sempre fazendo as coisas o mais rápido possivel. Não dá tempo de se proteger; você tem que ir logo. Somos até cobrados por isso, mas quando se vê, já estamos com a mão, já estamos fazendo isso. O certo era que se calçasse luva Porque a sirene toca, daqui que você corra para o posto para pegar os materiais, não dá tempo. Aí quando está se esvaindo em sangue...Você tem que conectar ligeiro, é onde você se contamina. Mas também, haja luva! Só o Senhor Jesus que protege. Que não tem como. Tem também aquele caso de paciente que está na enfermaria, normalmente, quando o médico vai pedir o exame, está tuberculoso.

Entrevistados 12,14,20,24,33.

Esse discurso dá mostras de que, para o profissional, o risco é fato consumado e também o é a desproteção. Parece permear as palavras, um sentimento de aceitação cega das condições, a que se inclui, permite-nos citar, o seu próprio desconhecimento. Por outro lado, admite-se que se é "cobrado" para adotar medidas que de certa forma os protegeriam. Mas cobrado por quem? E como?

Talvez essas reflexões tenham que ser juntadas às tantas outras suscitadas, quando do pensar num programa efetivo de biossegurança nas instituições hospitalares. Há que haver formas de apreensão dos conhecimentos nessa área, que ultrapassem à simples obrigação, à simples cobrança, sob pena de que sentimentos como esses ora em tela, em que a aceitação pura e simples parecem dar o tom do discurso, constitua-se na regra e não na exceção. 
É possivel que o aspecto que entendemos como de aceitação seja reflexo da própria condição da enfermagem. Para STEAGALL -GOMES (1986), até pouco tempo atrás, a categoria era educada para a submissão, servidão, resignação e passividade. Até hoje, muitos dos profissionais da área sentem-se felizes em servir, acreditam que seus males vêm por determinação divina e, consequentemente, não se protegem como deveriam. E, ainda, têm o comportamento reforçado pelas instituições que valorizam o histórico sentimento de abnegação, filantropia e caridade dos seus trabalhadores.

Ainda que seja belo e desejável o sentimento de compaixão, não é mais desse profissional que as instituições necessitam, para prestar assistência de qualidade aos pacientes, com segurança, para os seus colaboradores.

\subsection{Significado do proteger-se na ótica dos entrevistados}

Quando questionados sobre o seu próprio significado de proteger-se, a maioria dos médicos e das enfermeiras descrevem-no sobretudo como um conjunto de técnicas a serem empregadas para isolarem-se dos agentes infecciosos. Abstraímos do repertório médico, todavia, cinco idéias centrais e dos enfermeiros dois discursos preponderantes, conforme ilustrado a seguir.

Quadro Síntese - Para você, o que significa se proteger de uma contaminação/ contágio no hospital?

Idéias Centrais - ( Profissionais Médicos)

\begin{tabular}{|l|l|l|l|l|}
\hline $\begin{array}{l}\text { A prevenção de } \\
\text { doenças, através } \\
\text { do uso de técnicas } \\
\text { específicas. }\end{array}$ & $\begin{array}{l}\text { A prevenção } \\
\text { inerente a proteção } \\
\text { trabalho } \\
\text { médico. }\end{array}$ & $\begin{array}{l}\text { A proteção para } \\
\text { como vida. }\end{array}$ & $\begin{array}{l}\text { Os exageros na } \\
\text { outro. }\end{array}$ \\
\hline
\end{tabular}

Idéias Centrais - (Profissionais Enfermeiros)

\begin{tabular}{l}
$\begin{array}{l}\text { Prevenção de doenças, através do uso de } \\
\text { técnicas especificas. }\end{array}$ \\
\hline
\end{tabular}

técnicas específicas. 
Os discursos de ambas as categorias profissionais, relativos à primeira idéia central, logo abaixo, explicitam que os cuidados devem ser tomados porque se desconhece os pacientes. Alguns conteúdos ilustram bem isso: "nem sempre se sabe com que tipo de paciente se está lidando"; "a gente tem que estar atento, ainda mais que você não sabe tudo daquele paciente"; "a gente tem muitos pacientes aparentemente sadios, mas que são portadores de graves doenças".

Idéia central - Prevenção de doenças, através do uso de técnicas específicas

\section{DSC - dos médicos}

Se proteger significa fazer profilaxia da doença. Não levar doença para casa. Proteger minha saúde e da minha família automaticamente. Se isolar, se proteger de algum agente que possa te contaminar, principalmente HIV e outras doenças contagiosas. Hepatite é uma coisa muito freqüente. Cresceu o número de pacientes com AIDS na região. Temos que conhecer a história do paciente e, no contato fisico, já se tem que ir tomando algumas medidas preventivas, fazer exames complementares. A gente tem muitos pacientes aparentemente sadios, mas que são portadores de graves doenças. A gente tem que estar atento. Ainda mais que você não sabe tudo daquele paciente. Tem-se que realizar os procedimentos dentro da técnica. Se o paciente pode transmitir a doença através do suor ou da saliva, por exemplo, tem-se que evitar entrar em contato com essas secreções. Ter materiais de proteção disponível.

Entrevistados $1,2,4,5,6,7,9,11,13,14,17$.

\section{DSC - dos enfermeiros}

Preservar-se significa utilizar-se de normas técnicas adequadas que vão até melhorar a qualidade da assistência, protegendo não só o cliente, mas também a equipe e a sua própria família. Significa evitar riscos de contaminação pessoal, usando equipamentos de proteção individual. Proteção de acordo com o que você vai desenvolver com o paciente. Se é uma doença infecto-contagiosa das vias superiores, ai você vai usar uma máscara para chegar no seu paciente. Nem sempre se sabe com que tipo de paciente se está lidado, então, proteção tem que ser com todo mundo. Quando se fala em todo mundo, diminui o risco.

Entrevistadas $1,2,3,4,5,6,7,8,9,10,11,12$. 
Depreendemos a preocupação, em especial no discurso dos médicos, com uma nova realidade que vêm se modificado e se tornando perigosa - "cresceu o número de pacientes com AIDS na região"; "hepatite é uma coisa muito freqüente".

O discurso dos enfermeiros parece, por outro lado, embora também ressalte de uma forma menos explícita a preocupação com o desconhecimento do que acomete os pacientes, mais ponderados e mais focados na importância da proteção da equipe como um todo e também na qualidade da assistência conferida ao paciente, quando instituídas medidas de proteção.

Os pensamentos dos sujeitos do estudo, por um lado, são perfeitamente confluentes com as regras propostas pela literatura, no que tange às medidas de auto-proteção, isso é, precauções universais/padrão a serem utilizadas no trato com a possibilidade do contato com sangue e secreções de todos os pacientes, independentemente do diagnóstico firmado ou presumido, e as precauções baseadas na transmissão através conhecimento da rota de transmissão dos diversos agentes. Entretanto, por outro, circunscreve a explicação para o emprego, principalmente das primeiras, pela falta de referência pessoal de seus pacientes.

Ainda quando se refere a "todo mundo", nos parece que transpira do discurso que esse "todo mundo" compõem-se de pessoas em suposta distância dos profissionais, ou seja, "para todo mundo" porque não se conhece "todo mundo". Assim surge a questão não respondida : E se supostamente se conhecesse o paciente? O mesmo conjunto de técnicas estaria validado? E mais, o que significa "conhecer"?

Transparece também, veladamente, a idéia de grupos de risco: "Temos que conhecer a história do paciente".

Preocupa-nos que o conceito de universalidade (para "todo mundo") constitutivo do discurso, possa trazer no seu bojo, salvo viés de entendimento, muito da noção de paciente conhecido/desconhecido, ao invés de realmente para todos. Parece-nos que, a partir daí o indesejável salto para as nuances dicotômicas - drogado/não drogado; hetero/homo; educado/deseducado; alto nível social/baixo nível social pode colocar como uma questão aceitável pelos profissionais, para a eleição de quando se 
proteger. Isso, além das implicações diretas dos riscos a que os profissionais poderiam vir a se submeter desnecessariamente, remete ainda à implicação ética da maior gravidade.

Nessa perspectiva, colocamos como questão fulcral, a necessidade do reforço ao emprego das medidas de biossegurança, em particular das precauções universais/ padrão, como forma de melhor aproximar os profissionais e seus pacientes da diminuição dos riscos biológicos. Para tanto essas medidas devem ser de fato de emprego universal, na acepção mesma da palavra, uso para todos. Não podemos deixar de estar alerta para o fato de que uma estratégia "racional" de criação de atitudes positivas em relação à prevenção tem que necessariamente considerar todo complexo de emoções, elaborações mentais, teorias e práticas explicativas do cotidiano que se inserem na constituição das representações sociais dos sujeitos e que atuam, conforme afirma TURA (1997), concretamente nas escolhas e alternativas elaboradas pelos indivíduos diante do risco.

Um segundo discurso médico explicita um significado para o proteger-se, que se aproxima um pouco mais dos modernos conceitos de biossegurança. Podemos dizer que o discurso emitido vem ao encontro do conceito de biossegurança enquanto prevenção da saúde do homem e do meio ambiente. Segurança entendida, conforme cita SCHRAMM (1998), tanto no sentido objetivo - associada à probabilidade aceitável do risco, quanto em sentido subjetivo - associada ao sentimento de bem estar. 
Idéia Central - A prevenção inerente ao trabalho médico

\section{DSC dos médicos}

Antes de qualquer definição do ponto de vista médico, é uma tendência natural de qualquer ser humano, até por questões de higiene, tem que haver o cuidado adequado. Todo mundo que tem naturalmente educação, tem uma formação para se proteger desse tipo de situação. Na formação médica, essa orientação se reveste de aspectos técnicos.

A gente tem a idéia de se proteger primeiro, pela importância, pelo risco, segundo pela, possibilidade de estender esse risco a outros. Você, sendo profissional da saúde, pode funcionar como um vetor. Você tem que insistir que não falte água e sabão no hospital. Que você seja um agente de conscientização das pessoas não ligadas à área de saúde e até de seus colegas. Acima de tudo, ter consciência de que se você adquirir uma infecção "brava" como a hepatite, isso pode até inviabilizar sua atividade profissional.

Entrevistado 10.

$\mathrm{O}$ discurso ao aludir a idéia de proteger-se, confere ainda um sentido político ao papel do profissional da saúde, na medida em que vai além de colocá-lo como um "vetor" ou "vítima" dos microorganismos, mas como agente de mudanças no seu ambiente de trabalho.

Um outro discurso coincidentemente entre os médicos e enfermeiros e também dos auxiliares/técnicos de enfermagem em menor medida, faz menção ao significado de proteger-se como proteção de vida. Embora pouco loquazes, esses discursos intentam uma visão do proteger-se mais abrangente que a adoção das medidas de proteção pura e simples. Vislumbram a proteção como um meio de preservar a saúde e a vida, seus maiores valores. 
Idéia Central - A proteção como vida

\section{$\underline{\text { DSC - dos médicos }}$}

\begin{tabular}{l}
$\begin{array}{l}\text { Se proteger é viver, em outras palavras...Bom ... Eu adoro viver...Eu adoro minha } \\
\text { vida. }\end{array}$ \\
\hline Entrevistados 8,12 .
\end{tabular}

Idéia central - Preservação da vida

\section{DSC - dos enfermeiros}

Me proteger de uma contaminação, na verdade, é preservar minha vida. Preservação de vida. Eu acho que cuidar. Cuidado eu gosto muito. Dar assistência. Mas sei que priorizo também minha saúde, minha vida. Tenho contato com outras pessoas e se eu contaminá-las, estar levando essa contaminação a outras pessoas [...]

Entrevistada 13.

Idéia Central- A proteção, a saúde

\section{DSC - dos auxiliares/técnicos de enfermagem}

Minha saúde que é o principal. Eu tenho, antes de tudo, que gostar de mim. Que gostar de mim. Eu acho que do trabalho também. É, você tem que gostar do que você faz. E você também tem que estar protegendo você e os colegas. Para mim significa "eu". O meu "eu". Eu estou fazendo bem para mim, para o paciente e para o hospital. É a saúde da gente em primeiro lugar.

Entrevistados 12,34,36,39

Um quarto discurso médico refere-se à proteção, não para si próprio mas para o outro. Embora pertinente a referência à proteção como resultante também da condição de saúde de cada um, e mais além, a análise de que, sob condições adversas como os baixos salários, os funcionários estariam menos protegidos face às suas condições nutricionais dentre outras, o discurso explicita um significado de proteger- 
se distante do interlocutor (o médico), o que pode denotar um possível sentimento de invulnerabilidade pessoal aos riscos biológicos.

Idéia central - A proteção para o outro

\section{DSC - Dos médicos}

A primeira coisa é a condição de saúde de cada um. Os funcionários ganham mal, são mal alimentados. Então se ele tiver uma alimentação por dia, ele garante um estado de nutrição.

Entrevistado 15.

O discurso apresentado conflui com o que refere SOUZA (2001), para quem é muito forte ainda a idéia de que o risco é apenas para o outro e nunca para si. Esse sentimento, segundo MENEGHIN (1996), pode ser visto como uma barreira, por parte do profissional em se proteger ou adotar hábitos de precaução.

Esse discurso, em alguma medida é complementado por um quinto e último discurso médico que não imputa exatamente um significado ao proteger-se, mas traça uma breve análise crítica sobre um superdimensionamento dos riscos e a busca de todo um supérfluo aparato tecnológico, que distancia o profissional da saúde do usuário dos serviços. Essa evocação, se de um lado é correta na medida em que se antecipa em uma crítica à paranóia dos riscos, por outro, pode estar a desvelar uma representação, tal como a apreendida do discurso anterior, de invulnerabilidade pessoal aos riscos. Um e outro, a paranóia e o sentimento de invulnerabilidade são problemas para a implementação, a contento, de medidas de auto-proteção. Para ilustrar esse tipo de sentimento recorremos às palavras de OLIEVENSTEIN (1989), que, ao falar da negação da possibilidade de adoecimento, afirma que esse pode representar, para a equipe de saúde, a parte não dita do medo-ódio, que as pessoas têm de ficar, elas próprias enfermas ou, em outras palavras, de uma posição "superior", para outra de "inferiorizado", de determinantes a determinados na relação com os demais. Visualizemos o discurso. 
Idéia central - Os exageros na proteção

\section{DSC - Dos médicos}

Do ponto de vista técnico, se você tivesse que usar a tecnologia que já existe, você teria que atender o paciente como se fosse um astronauta. Não existem esses riscos todos. A incidência de contaminação em pessoas que trabalham na área de saúde, em termos percentuais, é bem pequena. Tomando os cuidados que devem ser tomados principalmente na manipulação de instrumentos cirúrgicos, de agulhas, ai não acontece.

Entrevistado 16.

Por último, o discurso da maioria quase absoluta dos auxiliares e técnicos de enfermagem. De súbito, evidencia-se o embaraço dos sujeitos da pesquisa com a questão e a hesitação na elaboração de uma resposta, depois a descrição, mais uma vez, do ambiente hospitalar impregnado de bactérias, excreções, secreções e riscos, seguida da explicação de que, frente a isso tudo, cuidados devam ser tomados, porque se depende do que se faz . 
Idéia central - $O$ estranhamento da questão, o medo da doença, o ambiente hospitalar impregnado de bactérias, a necessidade do trabalho.

\section{DSC - Dos auxiliares e técnicos de enfermagem}

O que significa? Eh, se proteger...Por que eu me protejo? Porque, olha só, se eu não me proteger, eu vou pegar alguma infecção. Porque, afinal das contas, a gente vive num ambiente contaminado. Num ambiente que está cheio de bactérias e germes. Você se expõe, coloca sua saúde em risco. A gente vai cuidar de um paciente e não sabe que tipo de infecção que ele pode ter. Se proteger é tudo. É em relação às vias aéreas, contra o sangue do paciente, urina, fezes. Esses são mais.É uma proteção para mim e até para o paciente também. Não correr risco, que no caso é da função. Não sei dizer assim propriamente. Porque se a gente adoecer não é bom nem para a gente, nem para o hospital. Porque que eu preciso me proteger? Porque eu dependo do que eu faço! Levar um organismo estranho na roupa para casa, que tem nossos parentes, que podem se contaminar através da gente. Até mesmo quando a gente vai chegando é aquele abraço.E até a contaminação leva à morte. Muita gente pensa assim: Pegar uma doença, ah, eu tenho medo de morrer. Eu tenho medo é de ficar doente. Ficar ali no quarto. Hepatite mesmo como minha colega ficou.

Entrevistados $1,2,3,4,5,6,7,8,9,10,11,12,13,14,15,16,17,18,22,23,24,25,26,27,28,29$, $31,32,33,34,35,37,38,40,41$.

A reflexão sobre o significado de se proteger se confunde com o porquê de se proteger. A tensão cuidado/descuido que se interpõe parece ser mais percebida como uma ameaça do que como um motivo para que se adotem práticas de auto-proteção efetivas. "Porque, olha só, se eu não me proteger eu vou pegar alguma infeç̧ão".

A adoção das medidas de proteção ocorre, em tese, porque adoecer não é visto como bom nem para si próprio, nem tampouco para as instituiçôes na ótica dos profissionais, em flagrante explicitação da preocupação com os supostos prejuizos institucionais com a doença dos seus trabalhadores. "Porque adoecer não é bom nem para a gente, nem para o hospital". 
A impressão que o discurso passa é a de que os profissionais se vêem como peças importantes de uma engrenagem e que, para que essa funcione bem, importa que eles estejam saudáveis, ou pelo menos livres dos riscos que o hospital está sempre a oferecer. Em contrapartida, o discurso descortina também que o mudar de lado, ou seja, desvestir o uniforme de profissional da saúde, para ser um paciente constitui-se motivo de preocupação. Vejamos:

"Muita gente pensa assim: pegar uma doença, Ah, eu tenho medo de morrer. Eu tenho medo é de ficar doente. Ficar ali no quarto. Hepatite mesmo como minha colegaficou".

Por fim, permeia os discursos de todas as categorias entrevistadas acerca da configuração de um significado de proteger-se, a preocupação de não estender os riscos que lhes são inerentes na sua labuta diária nos hospitais, para os entes que lhes são caros: familia, parentes e amigos.

\subsection{As reações frente à possibilidade de contágio/contaminação}

A partir da questão "se você se contaminasse ou se contagiasse durante suas atividades no hospital, qual seria sua reação?", as respostas recaíram em dois núcleos principais: o discurso daqueles que acreditam ter uma por reação pessoal suscitada diante da possibilidade da contaminação/contágio, e daqueles que acreditam enveredar pelo caminho da reação enquanto providências.

A intenção da pergunta era a de perscrutar as reações pessoais no sentido evocado pelo primeiro grupo, para dimensionar o impacto do acontecimento de eventual contaminação/contágio na pessoa do trabalhador da saúde. Todavia às providências a serem adotadas, frente à um fato concreto, não diminuiu a profundidade dos discursos emitidos. Ao contrário, ao nosso ver, acrescentou variável importante, a saber, existem as reações pessoais, elas são relevantes, mas os profissionais também estão pensando, antes de se imaginarem tensos, nervosos, em pânico ou calmos ou outro sentimento, em reações pragmáticas diante da eventualidade levantada. 
Posta a possibilidade de contaminação/contágio pessoal durante as atividades no hospital, os médicos centram-se principalmente no processo de diagnóstico e do tratamento. As respostas apontaram para uma procura difusa: "um colega ou um grupo"; "Todos os possíveis que existissem, iria onde tivesse o recurso buscar o tratamento". Situemos as principais idéias e o primeiro discurso.

Quadro Síntese - Se você se contaminasse ou se contagiasse durante suas atividades no hospital, qual seria sua reação? (Profissionais Médicos)

\section{Idéias Centrais}

\begin{tabular}{|l|l|l|l|l|l|}
\hline $\begin{array}{l}\text { A busca do } \\
\text { diagnóstico e } \\
\text { do } \\
\text { tratamento. }\end{array}$ & $\begin{array}{l}\text { A procura } \\
\text { da CCIH. }\end{array}$ & $\begin{array}{l}\text { O acidente } \\
\text { como rotina. }\end{array}$ & $\begin{array}{l}\text { O susto e a } \\
\text { preocupação } \\
\text { com a suposta } \\
\text { desproteção. }\end{array}$ & $\begin{array}{l}\text { Imprevisíveis } \\
\text { reações. }\end{array}$ & $\begin{array}{l}\text { O } \\
\text { preparo } \\
\text { pessoal. }\end{array}$ \\
\hline
\end{tabular}

Idéia central - A busca do diagnóstico e do tratamento

\section{DSC dos médicos}

Procuraria um colega, ou um grupo para me diagnosticar, porque normalmente a gente não raciocina, se acontece uma coisa dessa com um parente ou consigo próprio. Ia me tratar. Dependente da contaminação, se por acaso fosse contaminado com hepatite $B$, tudo bem, porque somos vacinados, mas se fosse assim uma secreção de um paciente com HIV, primeiro plano era usar logo o coquetel. Logo, logo, em vinte e quatro horas. Saber do seu paciente, se ele tem alguma sorologia positiva, para a partir dai, tomar as medidas necessárias. Mas, inicialmente, fica a coisa do lavar mesmo com água e sabão. Fazer a sorologia para hepatite $B, C$, AIDS. Procurar vacinação ou medicação que pudesse minorar o problema. E até procurar outros meios de tratamento. Todos os possiveis que existissem, iria onde tivesse o recurso, buscar o tratamento.

Entrevistados $1,3,4,6,8,14,17,18,19$

Podemos notar que, mais uma vez, as maiores preocupações recaem, sobretudo, na contaminação/contágio por vírus transmitidos pelo sangue e nos acidentes que os viabilizam. Não se cogita outra possibilidade "inicialmente fica a coisa de lavar mesmo com água e sabão", "fazer a sorologia para hepatite B, C e AIDS". 
As reações ficam, pois, na dependência do tipo de contaminação. Pela primeira vez aparece no discurso médico, o reconhecimento da proteção conferida pela vacina contra a hepatite B: "Se por acaso fosse contaminado com hepatite B, tudo bem. porque somos vacinados". Por outro lado, as tensões aumentam com a possibilidade de contaminação com o HIV: "Se fosse assim uma secreção de um paciente com $H I V$, primeiro plano era usar logo o coquetel, logo, logo em vinte e quatro horas".

Abstraimos, assim, que há no imaginário médico, um certo esboço das condutas que devem ser empreendidas, diante de uma exposição com sangue e secreções, esboço, todavia, ainda demandante de apropriada solidez .

Observamos ainda, que no discurso, não se faz menção à necessária notificação imediata do eventual contágio/contaminação às respectivas chefias e órgãos competentes da instituição, para a adoção das providências cabiveis de registro, indicação precisa de condutas e acompanhamento do profissional, dentre outras. Ao contrário, depreendemos de suas falas que a eventualidade do acidente constituir-seia em um acontecimento de foro individual e as condutas adotadas, seriam por seus próprios colegas, sem envolvimento institucional.

Esses resultados vem ao encontro da constatação de FIGUEIREDO (1992), que afirma que a classe médica não tem o hábito de notificar os seus próprios acidentes. SOUZA(2001), declara, de igual modo, que, na prática, os profissionais de saúde nem sempre procuram os setores específicos em busca de atendimento imediato, quando da eventualidade de um acidente que envolva material biológico.

A prática de não se procurar os órgãos apropriados nos hospitais para a comunicação dos acidentes, remete a dois problemas principais. O primeiro relacionado à instituição das medidas cabíveis de forma sistematizada, em tempo hábil, quando for o caso, e o segundo, ao sub-registro dos dados acerca dos acidentes de trabalho, notadamente daqueles relacionados aos riscos biológicos.

A subnotificação da ocorrência de acidentes, de causas múltiplas, muitas delas existentes por conta do próprio sistema de notificação utilizado no Brasil, que toma o registro enquanto forma de concessão ou não de benefícios previdenciários que 
inviabiliza o conhecimento epidemiológico real dos eventos, dificultando não apenas um trabalho mais aprofundado nas próprias instituições, mas inclusive a adoção de políticas públicas pertinentes. Entende-se o adequado registro como braço importante da vigilância à saúde, e essa, vigilância, por seu turno, não como mera ação da produção de informação, mas, fundamentalmente, conforme MENDES et al. (1999), como intervenção sobre determinantes e condicionantes de problemas de enfrentamento contínuo que incorpora, também, ações de caráter individual.

Em contrapartida, uma outra parte dos médicos emite um discurso que privilegia, como primeira reação, a procura da $\mathrm{CCIH}$ para notificar uma possível contaminação/contágio, bem como para a adoção de providências. Reconhecem na $\mathrm{CCIH}$ o papel de portadora de um cabedal científico que a habilita a adotar, de forma mais apropriada, as condutas pertinentes, como também fornecer as informações necessárias. Chama-nos a atenção que a maior preocupação rebate mais uma vez no acidente com materiais pérfuro-cortantes.

Idéia central - A procura da $\mathrm{CCIH}$

\section{DSC - Dos médicos}

Existe um protocolo. Se você se contamina com pérfuro-cortante existe todo um protocolo na CCIH. Deve-se informar à CCIH. Comunicar a CCIH, porque ela está habilitada não só legalmente, como vai ter as medidas de rotina que são de um acidente.

Entrevistados 5,10,12.

O discurso acima é compartilhado também pela maioria dos enfermeiros e de boa parte dos auxiliares e técnicos de enfermagem entrevistados. Para esses últimos, há, contudo, uma certa falta de direcionamento na busca da possível notificação do ocorrido. Uma maioria refere-se à procura da chefia imediata, gerências, e da direção do hospital. Desconcentração possivelmente explicada pelo fato de não haver em todas as instituições às quais os profissionais estão vinculados, a $\mathrm{CCIH}$, como grupo executivo, muito embora todos os hospitais nos quais procedemos às entrevistas para o estudo qualitativo disponham da $\mathrm{CCIH}$ enquanto órgão legislativo. 
Precede, por outro lado, tanto no caso dos enfermeiros, como dos demais auxiliares e técnicos de enfermagem, à procura dos órgãos respectivos em suas instituições, o emprego de cuidados locais com a área supostamente atingida por sangue e secreções. Medidas estas à julgar pelas falas, em particular no discurso dos auxiliares e técnicos de enfermagem, executadas com um rigor de algum modo desmesurado e que desvela o temor da contaminação: "A gente lava, lava, passa escova e torna a lavar e vai logo jogando álcool".

Por uma questão de organização dos dados, ilustra-se a seguir, todas as idéias centrais dos enfermeiros e dos auxiliares e técnicos de enfermagem, e então, os respectivos discursos concernentes à idéia central ora em questão, em que há congruência entre as três categorias profissionais.

Quadro Sintese - Se você se contaminasse ou se contagiasse durante suas atividades no hospital, qual seria sua reação? Profissionais Enfermeiros

Idéias centrais

\begin{tabular}{|l|l|l|}
\hline A procura da CCIH. & Imprevisíveis reações. & O pânico. \\
\hline
\end{tabular}

Quadro síntese - Auxiliares e técnicos de enfermagem

Idéias Centrais

\begin{tabular}{|c|c|c|c|c|}
\hline $\begin{array}{l}\text { A procura da } \\
\text { CCIH, r de } \\
\text { profissionais e } \\
\text { outros órgãos } \\
\text { institucionais. }\end{array}$ & $\begin{array}{l}\text { A reação } \mathrm{d} \\
\text { medo e d } \\
\text { pavor. }\end{array}$ & $\begin{array}{l}\text { Reações } \\
\text { imprevisíveis. }\end{array}$ & $\begin{array}{l}\text { A } \\
\text { responsabilidade } \\
\text { pessoal. }\end{array}$ & A aceitação. \\
\hline
\end{tabular}


Idéia central - A procura da $\mathrm{CCIH}$

\section{DSC - Dos enfermeiros}

Procurava a CCIH para tentar fazer os exames necessários. Já tem rotinas para esses casos. Mas aqui a gente teve problemas. Uma funcionária se contaminou com pérfuro-cortante, a CCIH foi informada e não adotou providências. Ficou aquele pingue-pongue. Antes lavava o local, passava algum anti-séptico, álcool, álcool iodado.

Entrevistadas $1,2,3,4,5,6,7,8,10,11,13$

Idéia central - A procura da CCIH, de profissionais e outros órgãos.

\section{DSC - Dos auxiliares e técnicos de enfermagem}

Procurava a CCIH para notificar o tipo de infecção quando o paciente está diagnosticado. Ai ela notificava e encaminhava a gente para o tratamento.Porque qualquer tipo de contaminação a gente tem que comunicar a CCIH, aí ela vai ver o procedimento. Primeiro entregava a causa à Deus, depois CCIH. Às vezes, acontece da luva furar. A gente lava, lava, passa escova e torna a lavar e vai logo jogando álcool. Procurava também de imediato o médico para ver o que ele pode fazer, a enfermeira da unidade, a gerência, a direção do hospital para serem tomadas as devidas providencias. Podia procurar um SESPI, a CIPA porque dai elas iam tomar outras providencias, tentar ver como a gente está coberta

Entrevistados $1,3,4,5,6,8,9,14,15,16,18,21,24,25,28,30,32,34,36,38$.

Destacamos que, dentre as enfermeiras que se reportaram à procura da CCIH como reação provável à contaminação/contágio pessoal no hospital citou-se ainda que não fosse este o cerne da questão, a ocorrência de caso de acidente com material pérfurocortante, sem que a $\mathrm{CCIH}$ tivesse adotado as providências cabíveis. $\mathrm{O}$ fato faz tornar visível a falta de clareza institucional de quem de fato responsabilizar-se-ia pelo evento e mais, deflagra no profissional uma desconfiança de sua real cobertura frente à possível eventualidade de um acidente. Vejamos a frase: "A CCIH foi informada $e$ não adotou as providências, ficou aquele pingue-pongue". Esse dado, conquanto não 
se tenha demonstrado recorrente em outras falas, reveste-se de importância porque flagra a fragilidade institucional relativa ao assunto, que não mais poderia se admitir.

Pode-se dizer o mesmo em relação ao discurso dos auxiliares de enfermagem que, não obstante atuarem todos em instituições providas de $\mathrm{CCIH}$, pelo menos enquanto órgãos legislativos, nem sempre demonstram a clareza necessária de quem devem procurar.

De acordo com o preconizado e a literatura ressalta, espera-se que, após qualquer tipo de acidente, o trabalhador procure o serviço próprio da instituição na qual se trabalha, a fim de notificá-lo. Em se tratando de acidente com material biológico, esse é normalmente notificado à $\mathrm{CCIH}$, onde o trabalhador também é atendido. $\mathrm{O}$ atendimento, por outro lado, deve ser realizado por um profissional habilitado que avalie os riscos da exposição e institua as medidas recomendadas para cada caso. Para a eficácia de eventual necessidade de instituição de medicamentos profiláticos, demanda-se que a notificação seja feita com a maior brevidade possível, preferencialmente nas primeiras duas horas após o acidente.

Porém, dificilmente se alcança esses objetivos, se não houver na instituição mecanismos de atendimento contínuo, bem como um programa específico de prevenção. Esse programa deve ser, outrossim, de amplo conhecimento dos trabalhadores e contemplar os cuidados a serem empreendidos no momento do acidente. Um programa efetivo, conclui SOUZA (2001), proporciona maior segurança e melhora a notificação intra-institucional.

Retornando aos discursos médicos, o terceiro discurso desses profissionais, volta-se para a adoção de medidas circunscritas aos cuidados locais, para a ocorrência de acidentes com materiais pérfuro-cortantes na presença de fluídos orgânicos, que depreende-se das falas, constitui-se rotineira. Nota-se ainda que os acidentes não são notificados, nem tampouco adotadas outras providências . 
Idéia central - $\mathrm{O}$ acidente como rotina

\section{DSC - Dos médicos}

Não saberia praticamente onde me contagiei. A não ser que percebesse que me furei numa cirurgia. Você estar fazendo uma cirurgia e um colega furar seu dedo e tal, como acontece. Vocé para, lava a mão e ai? É uma contaminação. Às vezes acontece de você furar uma luva, o que é que se faz... Troca-se a luva, joga-se um soro fisiológico, coloca-se outra luva e continua. Não procuramos saber se o paciente estava contaminado, com isso, com aquilo, com aquilo outro. No inicio a gente tem... mas depois, não sei, parece que a gente relaxa.

Entrevistados 7,11,20.

Parece haver, pelo conteúdo emitido, um certo descrédito de que algo mais possa e deva ser feito. Pelo menos algo que venha trazer algum beneficio. Depreende-se também do discurso. que os profissionais já se preocuparam mais com a questão do acidente com material biológico. As palavras seguintes desvelam um pouco desse sentido: "No inicio a gente tem... mas depois, não sei, parece que a gente relaxa".

Esse estado de coisas nos leva a indagar: os profissionais não estariam convencidos dos riscos? Fazendo uma análise cruzada, depreendemos que os médicos que construíram com suas falas o discurso ora sob análise confirmaram o envolvimento dos riscos durante o desenvolvimento de suas atividades nos hospitais, quando da questão especifica. Registraram também que se protegem de uma forma ou de outra de contaminação/contágio.

O discurso ora analisado pode nos levar à reflexão da plausibilidade de que o envolvimento em inúmeras atividades leve o profissional à não desejar despender tempo com os considerados "pequenos acidentes". Como questão de fundo, talvez esteja o sentimento de que os riscos embora possam existir, não sejam tão expressivos. Também é possivel que os médicos não estejam convencidos da efetividade das condutas pós exposição ou até mesmo as desconheçam, ou não têm segurança de que as instituições nas quais trabalham disponham de infra-estrutura mínima que permita respostas efetivas às suas eventuais demandas. 
Ressaltemos ainda que os médicos sujeitos deste nosso estudo não possuem vínculo empregatício com as respectivas instituições. Nelas desenvolvem suas atividades e são remunerados de acordo com sua produtividade. Esse é um fator que pode, certamente, influenciar na subnotificação de eventuais acidentes. Diversos trabalhos tratam da problemática da subnotificação de acidentes com materiais pérfurocortantes por parte dos profissionais atuantes em hospitais.

Pesquisadores do CDC estimam que nos Estados Unidos, a subnotificação de acidentes de trabalho relacionados especificamente a materiais pérfuro-cortantes chegue a 50 a $80 \%$ (JORNAL DA SBI 1995).

HOFFMAN et al. (1992), em estudo desenvolvido em hospital localizado fora de centro urbano nos Estados Unidos, verificaram taxas de acidentes com agulhas de sutura, consideradas pelos autores como alarmantes entre os médicos. Detectaram ainda importante subnotificação dos acidentes, cuja principal razão recaía na percepção dos profissionais de que a exposição sofrida não seria um risco. TANDBERG et al. (1991), verificaram que apenas 35\% de injúrias percutâneas sofridas em cinco anos por médicos, enfermeiros e técnicos de unidades de emergência americana foram notificados. Os médicos registraram $1 / 8$ dos acidentes sofridos, enquanto os enfermeiros e técnicos notificaram 2/3. Os fatores preditivos para a não notificação foram a baixa percepção do risco, o número de anos de trabalho e a referência à burocracia envolvida no processo de registro. RODRÍGUEZ et al. (1999), em hospital espanhol, detectaram que 66\% dos acidentes ocorridos em um ano com profissionais atuantes na instituição analisada, envolvendo materiais pérfuro-cortantes, não foram registrados. Os elementos que mais se relacionaram à subnotificação foram o tempo de serviço do profissional, o trabalho em unidade cirúrgica e a crença, de igual modo, apreendida nos estudos citados anteriormente, de que os acidentes não envolviam riscos à saúde. SHIAO et al. (1999), em investigação empreendida em dezesseis hospitais de ensino chineses, com uma amostra de 8.645 profissionais médicos, enfermeiros, técnicos e pessoal de suporte, verificaram que $87,3 \%$ sofrera acidentes recentes com material pérfuro-cortante. $81,8 \%$ das injúrias não foram notificadas e a categoria que menos registrou os eventos foi a médica, com uma taxa de sub registro de $85,2 \%$. As razões dadas para o 
não registro foram, de acordo com os pesquisadores, a referência a que o material envolvido no acidente não havia sido usado (34\%); crença de que o acidente não envolvera riscos $(21,7 \%)$; desconhecimento acerca da necessidade de registrar o evento $(14,9 \%)$; referência à falta de tempo $(14,9 \%)$ e sentimento de que consideravam-se imunes à hepatite $\mathrm{B}(12,4 \%)$.

FIGUEIREDO (1992), em estudo desenvolvido em hospital escola de Campinas-SP acerca de acidentes de trabalho sofridos por várias categorias de servidores, verificou como fatores predominantes relacionados a subnotificação, os problemas burocráticos $(50,7 \%)$, o julgamento de que as lesões sofridas eram pequenas $(28,2 \%)$ e a falta de tempo $(10,4 \%)$. No mesmo hospital, pesquisando especificamente a categoria de enfermagem, BENATTI (1997), detectou que 50,5\% dos acidentes ocorridos no período da pesquisa foram notificados por meio da comunicação de acidentes de trabalho (cat) e 49,5\% não foram notificados, havendo diferença estatística entre a notificação dos acidentes entre os profissionais efetivos da instituição, 61,1\% de notificação, e profissionais não efetivos - 36,6\%. A autora acrescenta que em vários casos os trabalhadores desconheciam onde notificar o acidente.BREVIDELLI (1997), por sua vez, procedendo à comparação de relato de ocorrência de acidentes ocupacionais com materiais pérfuro-cortantes envolvendo profissionais de enfermagem e seu respectivo registro no Hospital Universitário de São Paulo, detectou subnotificação da ordem de 51\% .LACERDA (2000), verificou, através de questionários respondidos por várias categorias profissionais atuantes em centros cirúrgicos nacionais, sub-notificação de $74 \%$ das ocorrências de exposição à sangue e outras substâncias corpóreas de pacientes. NAPOLEÃO (1999), em estudo desenvolvido em Hospital de médio porte (69 leitos) de cidade do interior de São Paulo verificou, através de entrevistas com trabalhadores da equipe de enfermagem, que $91,9 \%$ referira ter sofrido e não ter comunicado acidente de trabalho no intervalo de 24 meses prévios à realização da pesquisa. 34\% dos acidentes não notificados estavam relacionados a corte e perfurações com agulhas, bisturis e instrumentos cirúrgicos e $15,6 \%$ à exposição da pele e mucosa a fluídos orgânicos.

As justificativas apresentadas pelos profissionais para não proceder à notificação em $53,1 \%$ dos casos; foram a percepção de que a lesão fora pequena e, portanto, sem 
importância; em $36,8 \%$ houve a alegação de desconhecimento da necessidade de comunicar o acidente e em $6 \%$ a falta de tempo.

SILVA (1996), acresce que uma das razões de subnotificação de alguns acidentes é o receio do acidentado de que o evento não sendo caracterizado, à princípio, como de grande vulto, como picadas de agulha e pequenos cortes, possa suscitar nos próprios colegas e chefias, juizo de valor como o da supervalorização do acontecido pelo acidentado, com fins considerados escusos como conseguir licença de trabalho e outros.

RABAUD et al. (2000), em estudo francês acerca do comportamento de enfermeiros frente à exposição ocupacional à sangue, verificaram que a razão mais alegada para justificar a não notificação de acidente envolvendo o referido fluido orgânico, foi a crença na suficiência da "boa anti-sepsia local" imediatamente após o acidente $(48,5 \%)$. O mesmo trabalho revela ainda que apenas $57 \%$ das vítimas consideraram a importância de determinar a situação sorológica do paciente para HIV e para as hepatites B e C imediatamente após o evento.

De todo o exposto, podemos refletir que, ainda que diferentes as formas de abordagem, os dados obtidos através da produção discursiva aqui analisada guardam congruência com os achados da literatura, os quais permitem-nos inferir que há necessidade de esforços adicionais que visem a melhoria do entendimento dos profissionais, acerca do risco e da relevância de se reportar as exposições acidentais, ainda que as considerem de pequena monta. Outro ponto que merece destaque é que os discursos são enriquecedores, na medida em que são evocados de forma espontânea, refletindo o imaginário profissional sobre o assunto abordado, sem $o$ eventual viés de uma questão dirigida.

Ao que se refere às reações pessoais frente à possibilidade de contaminação/contágio acidental durante desenvolvimento de atividades no hospital, por outro lado, os discursos dos profissionais entrevistados são expressos enquanto sentimentos que vão do susto e pânico à aceitação. 
Os médicos rememoram situações vividas de exposição pessoal à sangue que envolveram medo. Manifestam-se também a respeito da complexidade de como dar satisfações, no meio social, de uma suposta contaminação com o vírus da AIDS, por exemplo. Embora com a visão de que expõem-se ocupacionalmente, a explicação de uma eventual contaminação pode se mostrar, no imaginário médico, também constrangedora, face ao preconceito. Na sua ótica, não haveria lugar, na sociedade, para o entendimento da possibilidade de contaminação no trabalho no caso da AIDS.

Idéia central - O susto e a preocupação com a suposta desproteção

\section{DSC - Dos médicos}

Reação meio de terror, de medo, já vivi uma situação. Por mais que você se previna, pode ser que um dia aconteça. Depois ainda vem aquele preconceito. $O$ cara se contamina com AIDS, depois para você explicar isso. É assustador. Não tem como. Você fica preocupado. Vez por outra estamos lembrando disso. Um médico que atua num centro de referência maior, como, por exemplo, a gente vê em filmes, você vê que eles usam todo um conjunto de procedimentos maior, maior amplitude do que nós usamos.

Entrevistados 2,9,13.

Expressa-se ainda, mais uma vez, a preocupação com a proteção pessoal que é vista como insuficiente, ainda mais se comparada com a empregada em maiores centros. Menciona-se, textualmente, o descompasso da realidade regional com o que se imagina de ideal no que se refere às medidas de biossegurança, conforme o fragmento seguinte pode ilustrar: "Um médico que atua num centro maior, como por exemplo, a gente vê em filmes, você vê que eles usam todo um conjunto de procedimentos maior, e de maior amplitude do que nós usamos". O enfoque de proteção, como se constata claramente no discurso, recai também, sobre o uso de equipamentos de proteção individual.

A explicitação desses sentimentos remete-nos à reflexão acerca da necessidade de que se levar em conta essas variáveis, quando de intervenções que visem a implementação de medidas de proteção nos hospitais, por parte dos gestores. Existe, 
por certo, uma infra-estrutura mínima necessária e há que se alcançar determinados patamares estruturais. Todos os recursos essenciais têm que ser disponibilizados. É possivel, no entanto, pelo que traz o fragmento acima, que os profissionais possam, de algum modo, "romantizar" um pouco o ideário de biossegurança e que, num outro extremo da carência de recursos indispensáveis, vislumbrem a necessidade de um cabedal estrutural, que pode ser supérfluo na realidade na qual atua, sobretudo, no que diz respeito aos EPIs. Isso não quer dizer, absolutamente, que com o que sonham os médicos já não se constitua nesse minimo indispensável, na medida das fragilidades estruturais dos serviços nos quais atuam.

Quando tomados os discursos dos enfermeiros, também eles supõem reação de pânico frente à possibilidade de contaminação/contágio no hospital. Sentimento compartilhado pelos auxiliares e técnicos de enfermagem. Embora manifestem ao menos esses últimos, o medo de doenças outras como a hepatite, as preocupações recaem, sobretudo sobre a AIDS. Os próprios discursos são auto-explicativos: " $a$ doença não tem cura" e "você pode até morrer".

Idéia central - O pânico

\section{DSC - Dos enfermeiros}

\begin{tabular}{l} 
Pânico. Acharia que iria "absorver" aquele tipo de patologia. Ia ficar logo \\
preocupada. \\
\hline Entrevistadas 6,8 \\
\hline
\end{tabular}


Idéia central - A reação de medo

\section{DSC - Dos auxiliares e técnicos de enfermagem}

Você pode até morrer. Ficaria amedrontado. Será que o paciente tem AIDS, será que tem hepatite, será que tem alguma coisa que passe por aqui? Uma reação de medo porque...Acho que se acontecesse, no inicio ia ser um nervosismo. Principalmente se for uma doença assim...vou citar...como o HIV. Até certo pavor porque a gente não sabe se aquele individuo está com uma doença perigosa. A primeira coisa que vem à cabeça é a AIDS. Será que fui contaminado pela AIDS? Eu ia enlouquecer. Ficar muito preocupado, com muito medo. Desesperar, fazer o quê? Eu morro logo, só de preocupação, pronto. Eu morro $\log$.

Entrevistados $2,5,6,10,17,21,33,35,40,41$.

Esses discursos tem confluência com afirmação de SOUZA (1999), de que as reações pessoais após acidentes com materiais pérfuro-cortantes, por exemplo, que envolvem a possibilidade de contato com sangue, são, em parte substantiva das vezes, de raiva, medo e pânico e a AIDS constitui-se, quase que invariavelmente, no maior temor manifestado pelos profissionais.

Alguns relatos, de pessoal de enfermagem que viveu a experiência do acidente são ilustrativas, conforme tomados pela autora supracitada, aqui transcritos.

"Eu falei: Meu Deus! e fiquei muito nervosa, chorei, fiquei muito apavorada. A primeira reação é a de pânico, mesmo que você sabe que o risco é mínimo";

"Na hora eu fiquei assustado, era paciente externo, a gente não sabe se ele tem alguma coisa";

"A reação foi susto, comecei a imaginar os pacientes que estavam lá, para imaginar o que poderia ser": 
"Na hora eu fiquei vermelha, o coração dispara, você fica desesperada. $O$ paciente olhou para mim e falou 'não se preocupe, eu não tenho HIV'. Ai eu fiquei mais tranqüilo";

"Na hora eu fiquei preocupada, o paciente era um rapaz de 23 anos. Ai a mãe dele falou para eu não me preocupar pois ele não saía de casa. Ai me acalmei. $O$ que mais preocupa a gente é a AIDS, a gente até esquece da hepatite, das outras coisas".

SOUZA (2001), de outra parte, perscrutando o que passaria pela mente do profissional, se, de repente, ele se imaginasse perfurando-se com uma agulha utilizada em um paciente sabidamente HIV positivo, verificou que quase todos os relatos de enfermeiros e auxiliares de enfermagem são permeados pelo medo de se contaminar e pelo transtorno emocional.

A autora também buscou saber dos sentimentos experimentados por profissionais que sofreram acidentes com materiais pérfuro-cortantes, independentemente do diagnóstico do paciente. Compilamos, para ilustrar, algumas falas.

"Fiquei muito apavorada sabendo do risco iminente" (Enfermeira);

"Fiquei muito preocupada com medo de ter me contaminado, pois a paciente era cheia de tatuagens" (Enfermeiro);

"Fiquei desesperada, sem dormir. Na hora, pensei que ia morrer e comecei a pensar nas coisas que nunca mais teria oportunidade de ver ou vivenciar. Fiquei num estado de choque" (Enfermeira).

Alguns profissionais de nosso estudo expressaram com relativa certeza, reação de medo frente à possibilidade de contaminação/contágio, outros, ao contrário, referiram dificuldade de preverem como reagiriam à esta possibilidade. 
Idéia central - Reações imprevisíveis

\section{DSC - Dos médicos}

Depende da doença. Claro que tem doenças mais temiveis. Você tem uma AIDS, uma coisa dessas, mas as reações são imprevisiveis. $\dot{E}$ dificil prever isso. Não saberia o que fazer.

Entrevistados 15,20.

\section{DSC - Dos enfermeiros}

A gente pensa que nunca vai acontecer. Não saberia dizer, não. A situação é complicada. Seria uma situação dificil.

Entrevistadas 9,12 .

\section{DSC - Dos auxiliares e técnicos de enfermagem}

Nem sei dizer. A gente está exposto à tudo aqui dentro. Já vi colegas terem problemas de septicemia. A gente está correndo risco de tudo aqui. Eu não sei não, viu! Não sei qual seria minha reação. Eu poderia ficar nervosa.desespero nunca, a gente sempre se preocupa, porque você vê tanta coisa. Ah, não sei, depende da contaminação.

Entrevistados $11,12,13,19,27$

Apreende-se dos discursos e, especificamente daquele proferido pelos médicos, que ainda que os sujeitos expressem dificuldades em prever como reagiriam, os discursos explicitam que essas reações estariam na dependência do tipo de doença em questão. Mais uma vez chama a atenção a AIDS e o seu estigma.

Salta, ainda, aos olhos, o dilema nos sentimentos aparentemente paradoxais entre o expresso pelos auxiliares e técnicos de enfermagem, o de que se está sempre exposto aos mais variados riscos biológicos no hospital : "A gente está exposto à tudo aqui dentro". Também, o sentimento dos enfermeiros de que a possibilidade de contaminação/contágio é uma possibilidade vista como remota. "A gente pensa que nunca vai acontecer". 
Um último discurso médico expressa posição diametralmente oposta àqueles que enfatizam a problemática da AIDS enquanto risco ocupacional, prevendo, ainda, reação de tranqüilidade frente à mínima possibilidade de se contaminar ao desenvolver suas atividades no hospital, ou seja, nas palavras do próprio sujeito "durante o cumprimento do dever".

Idéia central - O preparo pessoal

\section{DSC - Dos médicos}

Quando se fala em contaminação hoje, se pensa logo em AIDS. Infelizmente algumas pessoas ainda pensam que AIDS se pega através do contato fisico. Nada disso é verdade. A AIDS é transmitida somente por via sexual e por transfusão sangüinea. E se acaso eu chegasse a ser contaminado com uma doença desse tipo eu não teria nenhuma revolta por tê-la adquirido tratando de um paciente. Porque eu acho que é meu dever. Eu gosto de atuar como médico.

Entrevistado 16.

Esse discurso é pertinente no que se refere à possibilidade de que os profissionais atuantes nos hospitais possam estar superestimando os riscos a que estão expostos, no particular caso da AIDS. Contudo, mais do que isso, ele pode estar a desvelar um sentimento pessoal, de invulnerabilidade aos riscos e ainda, uma convicção de que contaminar-se/infectar-se durante o desenvolvimento das atividades laborais possa se dar em decorrência natural do ofício, o que não é verdadeiramente o que se espera.

O mesmo discurso, todavia, não aparece solitário na configuração de um cenário no qual inclui-se os discursos de profissionais outros. Assim, observamos que corroboram, em alguma medida, abstraída a questão da AIDS, os conteúdos de dois discursos emitidos pelos auxiliares e técnicos de enfermagem. 
Idéia central - A responsabilidade pessoal

\section{DSC - Dos auxiliares e técnicos de enfermagem}

Reagiria normal. Buscaria saber se eu peguei aquela doença, problema que eu mesma adquiri e não me protegi. Foi uma falta de exigência minha. Fui eu que não tomei cuidado, tinha que procurar me cuidar. Não seria assim nada demais. Seria aquela preocupaçãozinha porque eu não tinha que ter me contaminado. De vez em quando me irrito porque penso assim: Ah, mas não devia ter acontecido isso. Eu acho que fui eu que não me cuidei.

Entrevistados 4,20,22,31,39.

Idéia central - A aceitação

\section{DSC - Dos auxiliares e técnicos de enfermagem}

Todo mundo corre risco. Desde quando você accitou essa profissão, você sabe dos riscos que está correndo, lidando com doentes. Procuraria preservar meus filhos e faria o possível para que aquilo não fosse adiante. Não ia ter muita reação, não, porque a gente que trabalha nessa área pode estar contaminado ou não estar. Nada acontece por acaso. Tudo que acontece na vida tem um porquê.

Entrevistados:23,24,26,29.

Conforme visualizamos nos quadros acima, em um dos discursos, os profissionais vêem-se reagindo com relativa normalidade à uma suposta contaminação/contágio no hospital. Assumem para si, por antecipação, a responsabilidade pelo evento que, sabemos, na hipótese de ocorrência, relaciona-se aos mais variados fatores, principalmente se considerada a problemática das limitações de infra-estrutura dos hospitais, limitações essas evocadas nos próprios discursos já discutidos neste estudo.

As falas revelam uma reação considerada pelos estudiosos do assunto comum dentre os trabalhadores, a de assumir como de sua inteira responsabilidade a ocorrência de acidentes, atribuindo-a, de acordo com SUAZO (1999), à sua imperícia e 
imprudência, mesmo que essa tenha como cenário, problemáticas condições ambientais e de organização do trabalho.

No outro discurso, exprime-se a aceitação de uma possível contaminação/contágio. Entende-se que uma vez abraçada ou "aceita", no próprio dizer do sujeito, a profissão da área de saúde, estabelece-se um inexorável vínculo com o risco, não cabendo maiores reações frente à contingência de uma contaminação, a não ser aceitar e procurar meios para que as coisas não andem adiante. Uma fala de um profissional expressa essa lógica: "Porque a gente que trabalha nessa área, pode estar contaminado ou não estar".

\subsection{Sobre o medo de se contaminar/contagiar}

Para a pergunta "você tem medo de se contaminar/contagiar com algo especial no hospital ? Alguma infecção especifica?", o discurso manifesto por parte expressiva dos médicos é o de que não há lugar para o medo. Mais duas idéias centrais, são ainda apresentadas, o medo na medida do risco e o medo da AIDS, conforme demonstra o quadro a seguir.

Quadro Síntese - Você tem medo de se contaminar com algo especial no hospital? Alguma infecção em especial? (Profissionais Médicos)

Idéias centrais

\begin{tabular}{|l|l|l|}
\hline Não há lugar para o medo. & O medo na medida do risco. & O medo da AIDS. \\
\hline
\end{tabular}


Idéia central - Não há lugar para o medo

\section{DSC-Dos médicos}

Não dá para trabalhar com medo, trabalhar com receio. Tem que acreditar no trabalho que é desenvolvido no hospital. Às vezes, passa pela cabeça. São fatalidades. A gente atender um paciente com meningite e desenvolver uma infecção meningocócica, que pode matar uma pessoa em seis horas, quem sabe em doze horas. Mas isso ai são fatalidades. Medo a essa altura da vida, não. Não se deve fazer restrições, mas se cuidar. Entrou-se nessa profissão se sujeitando à essas coisas. Se acontecer algo, deve ter caráter de normalidade. Se houvesse o medo, não se fazia tantos procedimentos, quantos a gente faz. O médico exerce uma função que... nos coloca muito próximo ai do que se chama DEUS, e se tem a proteção dele.

Entrevistados 5,6,14,15,16,18,19,20.

Nesse primeiro discurso, a própria possibilidade de se adquirir uma infecção é vista como uma fatalidade. O medo constante, caso existisse, constituir-se-ia em um elemento restritivo ao desenvolvimento pleno do trabalho no hospital. A frase seguinte abstraída do discurso dá essa medida: "Se houvesse o medo, não se fazia tantos procedimentos quantos a gente faz".

Admite-se, todavia, mais uma vez, os riscos e a necessidade de se proteger: "Entrouse nessa profissão se sujeitando a essas coisas", "não se deve fazer restrições, mas se cuidar".

Desvela-se, entretanto, num outro extremo, uma outra faceta que, em nossa ótica, pode demandar atenção por parte das lideranças responsáveis pela implementação de medidas de biossegurança nos hospitais. Trata-se de fragmento de discurso que fala da proteção divina, aqui transcrito: "O médico exerce uma função que [...] nos coloca muito próximo ai do que se chama DEUS, e se tem a proteção Dele".

Uma das interpretações para essa metáfora pode ser a simples visão da grandiosidade auto-atribuída ao trabalho médico, o que por si só não parece trazer maiores 
conseqüências para o assunto aqui abordado - a biossegurança -, do contrário. Face a importância de seu trabalho, o médico teria, no seu entendimento, a proteção divina e isso não quer dizer que necessariamente deixaria de adotar medidas de auto-proteção.

Outra possibilidade, contudo, é a do entendimento de que, por desenvolver um trabalho especial, o profissional se consideraria naturalmente protegido de eventuais riscos. Essa segunda alternativa, apartada do excesso, pode interferir na adoção de medidas de biossegurança, pois pode estar a retratar, mais uma vez, uma tendência em se acreditar em invulnerabilidade pessoal, conforme já discutido neste texto.

De igual modo aos médicos, as enfermeiras, relatam que o medo de contaminar-se no hospital não se constitui em elemento que permeie o desenvolvimento de suas atividades. Confirmam que o risco é inerente ao próprio trabalho. Tem-se, segundo elas, um certo receio, uma certa preocupação, pois de acordo com elas próprias, "se está vulnerável" e, assim, tem-se que tentar se proteger ao máximo.

Quadro Síntese - Você tem medo de se contaminar com algo especial no hospital? Alguma infecção em especial? (Profissionais Enfermeiros)

Idéias centrais

\begin{tabular}{|l|l|}
\hline Um certo receio. & O medo da AIDS. \\
\hline
\end{tabular}


Idéia central - Um certo receio

\section{DSC - Dos enfermeiros}

Tem-se receio, uma certa preocupação, porque se está assim, vulnerável, mas não medo. É um risco que se corre diariamente e se tiver medo, não se faz nada. Tem que tentar se proteger ao máximo, de HIV e outros. Para o HIV, não é feito exame como rotina. Há também um número alto de hepatite C. Para o vírus $B$, já somos imunizados. Para o virus $C$ não tem vacina. Tem-se a preocupação com a questão do sangue e derivados, a possibilidade de contaminação é grande. Existem as infecções respiratórias, meningite, tuberculose, mas a preocupação não $\dot{e}$ exacerbada, porque se tenta se proteger. O medo existe, mas na nossa profissão é com ele. AIDS, hepatite, se receia, mas nada que determine o afastamento do paciente. Eu tenho medo da meningite e da hepatite, quando estou com uma seringa, eu fico tensa mesmo, mas medo não, talvez uma certa preocupaçãozinha As vezes, falta um pouco de conhecimento de como é que se contrai as doenças, o que gera o pânico. Então muita gente fica em pânico.

Entrevistadas 1,2,3,5,7,8,10,11,12.

A questão dos microorganismos veiculados pelo sangue põe-se às enfermeiras como motivo de preocupação, pois em sua ótica, é grande a possibilidade de contaminação por esse meio. O HIV é o que desperta as maiores tensões e uma das justificativas é a de que não são realizados, de rotina, nas instituições, exames para a detecção do vírus, o que as obriga a lidar com pacientes potencialmente infectados, desconhecendo-se essa condição. Surpreende-nos, assim, arestas no entendimento das já discutidas precauções universais/padrão, no corpo deste trabalho, arestas que conduz-nos para uma problemática de cunho ético, qual seja a realização de rotina de exame em todos os pacientes, para o HIV.

No mesmo discurso, a hepatite $\mathrm{C}$ também é lembrada como doença numericamente importante, grave e para a qual ainda não se dispõe de vacinas. Citam-se outras infecções, como a meningite e a tuberculose, como fontes pouco menos expressivas de preocupações, mas ainda assim dignas de nota, embora depreenda-se dos 
discursos que considera-se contra essas doenças a proteção pessoal como mais factível.

Finalizando o discurso desses enfermeiros, registra-se o contradiscurso do medo, o qual é explicado pelos sujeitos do estudo, como produto do desconhecimento das formas de transmissão das doenças por parte da própria categoria onde se incluem: "As vezes falta um pouco de conhecimento de como se contrai as doenças, o que gera o pânico. Então muita gente fica em pânico".

Alinhado a esses primeiros discursos dos médicos e dos enfermeiros, afigura-se um segundo discurso médico que, ainda que não seja tão enfático quanto ao primeiro no que se refere à inexistência do medo de contaminar-se/infectar-se durante o trabalho, também o expressa de maneira bastante relativizada.

Idéia central - O medo na medida do risco

\section{DSC - Dos médicos}

A gente sabe do risco. Todo profissional da saúde convive com..., não seria esse medo, mas seria com o risco. Todo mundo que mexe com bactérias, corre risco. O medo vai diminuindo à medida que se vai fazendo e pegando o hábito. Aumenta-se a segurança, diminui o risco. Optou-se por isso, tem que encarar os riscos. Das doenças, a pior, por conta da probabilidade maior, seria a hepatite, particularmente a $C$. As pessoas pensam muito em AIDS, mas a possibilidade de contágio com AIDS, embora exista, é menor e tem situações mais graves. Hepatite $C$ é mais problemática, o paciente de AIDS quando você sabe, já se toma precauções maiores, o de hepatite é mais complicado. Às vezes, não se tem essa identificação porque a hepatite já existe há muito tempo e as pessoas não têm 'a mesma preocupação que tem com a AIDS.

Entrevistados 1,2,11,10,17.

Para os médicos que compartilharam desse discurso, todo o profissional de saúde convive com o risco, que têm que enfrentar, e, se o medo existe, ele vai diminuindo à medida que os profissionais tornam-se mais experientes: "Aumenta-se a segurança, diminui o risco". Ainda neste discurso, também se atribui à hepatite $\mathrm{C}$ a maior 
importância do ponto de vista ocupacional. Primeiro, na ótica dos sujeitos, pela maior probabilidade de transmissão, e depois, por se constituir mais complexa a adoção de medidas preventivas para essa infecção, contrariamente à AIDS.

Igualmente aos demais profissionais sujeitos do presente estudo, também parcela expressiva dos auxiliares e técnicos de enfermagem entrevistados comungam da idéia de que o medo de contaminar-se/contagiar-se, não faz parte da rotina do seu trabalho. Pressupõem que se protegem, tomam os seus cuidados, e assim, como boa parte dos médicos e enfermeiros, estão convencidos de que se houvesse medo não haveria como se manter na profissão.Percebe-se, todavia, que suas falas são impregnadas de uma resignação que possivelmente se relacione à históricas características dessas profissões no trabalho hospitalar, ressaltando-se os valores religiosos(conformismo e submissão) e à vocação( trabalho por amor,satisfação com a profissão).(SIQUEIRA et al 1995).

Nos antecipemos ao discurso propriamente e vejamos alguns conteúdos que vem ao encontro dessa possibilidade: "se acontecer é porque tinha que acontecer"; "você é muito especial e com isso acho muito dificil acontecer"; "se trabalha pensando não em ser contaminado, mas em ajudar o paciente";" tudo acontece de acordo com nossa jornada na vida"; " a gente confia muito com Deus, trabalha com fé Nele mesmo"

Fazem contraponto com o discurso, no qual se expressa o pressuposto de se estar protegido, uma segunda idéia central, mais adiante discutida, a do medo das doenças, conforme mostra o quadro.

Quadro Síntese - Você tem medo de se contaminar com algo especial no hospital? Alguma infecção em especial? (Auxiliares e técnicos de enfermagem)

Idéias Centrais

O pressuposto de estar protegido.

O medo das doenças e a ênfase na AIDS 
Idéia central - O pressuposto de estar protegido

\section{DSC - Dos auxiliares e técnicos de enfermagem}

A gente pressupõe que se protege. Talvez por isso não se tenha medo. Procura-se trabalhar para não se contaminar. Se acontecer é porque tinha que acontecer. Não se vai correr o risco de se contaminar se o que tem que se fazer é ter muito cuidado Você é especial e com isso acho muito dificil você se contaminar. Se trabalha não pensando em ser contaminado, mas em ajudar o paciente. Se houvesse medo não se aceitaria essa profissão. Não há essa palavra: medo. Tudo acontece de acordo com nossa jornada na vida. Nada acontece por acaso. Você tem que se proteger, usar luvas, máscaras, porque se eu já sei que o paciente está com uma doença, então eu vou me prevenir. Se por acaso tiver que pegar uma doença, pega-se em casa tambẻm. Quando a gente trabalha sem medo, a doença não chega para a gente.A gente confia muito em Deus, trabalha com fé Nele mesmo. Quando a gente trabalha confiante em Deus e se protege, nada de ruim vai acontecer.

Entrevistados 1,3,4,6,9,15,17,18,21,22,23,25,26,29,30,31,32,35,38,39.

Se, de um lado é verdade que do discurso de boa parte dos profissionais aqui entrevistados abstrai-se que não há espaço para o medo de contaminação/contágio durante o desenvolvimento de suas atividades nas instituições hospitalares, não é menos verdade que também não são tão poucos aqueles que expressam o seu temor com veemência. Não nos iludamos que a apreensão frente aos riscos biológicos não permeie os meandros do hospital. Daqueles que expressam temerosidade à pergunta "você tem medo de se contaminar/contagiar com algo especial? Alguma infecção em especial?", as respostas são quase uníssonas: da AIDS. 
Idéia central - O medo da AIDS

\section{DSC - Dos médicos}

Com o advento da AIDS, a gente se preocupa muito com isso. HIV, essa é para nós, para todo mundo, principalmente para quem trabalha em centro ciruirgico a mais preocupante. Pelas caracteristicas da doença. Porque não tem prevenção para contaminação com secreção, não tem prevenção. O grande medo são os vírus da hepatite e da AIDS. Para o vírus $B$ a vacina é norma de segurança, mas o vírus da AIDS, enquanto não houver vacina é um medo constante, porque ninguém está livre. A gente sabe que tem esse lance, não é? Essa coisa ai de AIDS, e tem o estigma da doença. A hepatite é realmente um risco, mas há a vacina. O grande terror é o HIV. O HIV é aterrorizante, porque tem todo o problema da doença e da discriminação. Até você provar que "focinho de porco não é tomada", como você fica, como você fica? HIV é um verdadeiro pavor. Pacientes tatuados... Todo tatuado, faz uso de drogas... É um horror a tatuagem. Paciente tatuado, é duas, três luvas.

Entrevistados $3,4,7,8,9,12,13$.

\section{DSC - Dos enfermeiros}

A AIDS é uma doença que não tem cura ainda. Uma coisa que está muito incipiente, um mistério. Existem aquelas medicações básicas, mas que não curam. HIV. HIV! é o principal. Tem a hepatite B também. Mas hepatite não é coisa assim que... É uma coisa que tem. que tem cura, que vai assim..., tem como fazer o tratamento se você tiver. HIV, não. HIV não existe um tratamento. É uma doença muito estigmatizada. Sofre-se muito mais pelo preconceito por ser HIV positivo do que por ter hepatite $B$. A AIDS é a primeira que a gente pensa. A que a gente está mais suscetivel hoje. Uma picada de agulha é muito fácil. E uma luva não dá proteção contra isso.

Entrevistados 4,6,9. 
Idéia Central - O medo das doenças, com ênfase no medo da AIDS

\section{DSC - Dos auxiliares e técnicos de enfermagem}

O HIV é uma coisa que todo mundo tem, tem medo. Não tem esse. Principalmente porque é uma coisa que ainda... não é curável de uma vez, é uma coisa que ainda está em estudo. É tanto que quando tem um paciente que é portador de AIDS, todo mundo fica no maior cuidado, redobra o cuidado e tal, não sei o quê e não punciona veia sem luva de jeito nenhum. O HIV que a gente tem paciente aqui,ou então aquele que é soropositivo e a gente vai saber depois, o receio maior é o HIV. Apesar de que não é só a AIDS, tem a hepatite $B$, mas o medo mesmo sempre é o da AIDS. Porque chega um paciente emagrecido, caquético, a gente logo diz... esse cara é aidético. Ai a gente olha a idade, se está com jeito de droga, a gente olha logo a pele dele, se tem marca, tatuagem, mancha, chama muito a atenção. Se perfurar com um escalpe de um paciente com HIV, hepatite, certos virus... Dá medo de todas as infecções, nenhuma em especial, principalmente do ambiente hospitalar, porque a maioria dos agentes patológicos são resistentes. Tem a meningite, a tuberculose. Tuberculose é uma que morro de medo de pegar, mas a AIDS, essa ai em primeiro lugar. As outras doenças, você tem como se precaver, tem como sarar, a AIDS, não se vê medida para isso.Tem muitos casos de HIV aqui, você assim, bonitinho e tal, sadio aparentemente, quando vem o resultado é um choque. Se disser que não tenho medo, estou mentindo, porque todo mundo tem. Eu tenho, você tem, todo mundo tem.Porque a gente que trabalha na área da saúde não está livre de certas doenças. Será que não está acontecendo comigo e eu estou sem saber? Tenho medo de me contaminar com tudo, hepatite, gangrena, a AIDS pior ainda. Porque de repente aparece um aidético forte ai. Deus me livre, a gente nem sabe porque eles estão no começo, não estão com aparência.E essa doença também, a sifilis, eu tenho assim receio de me contaminar com ela.Porque às vezes, quando a gente é contaminada, as pessoas pensam assim: "Que nada. está saindo com fulano". Já fica imaginando quando é assim uma doença venérea. Ninguém acredita que a gente pegou de alguém no hospital. Como a AIDS também, jä pensam logo que... Também tem os condilomas. A gente redobra os cuidados e avisa: "Oh, tem gente(no quarto) seis.

Entrevistados $2,5,7,8,10,11,12,13,14,15,16,19,24,27,28,33,34,36,40,41$. 
De acordo com os discursos, a AIDS é vista como doença/infecção mais preocupante, tomando-se as próprias palavras dos sujeitos da pesquisa, porque "para ela não há vacina", "não tem prevenção" e "enquanto não houver vacina, vai ser um medo constante", "Existem as medicações, mas que não curam".

Interessante notar que não só os discursos convergem para um mesmo foco, mas também tem praticamente um mesmo repertório vocabular, independentemente da categoria profissional: médicos, enfermeiros, auxiliares e técnicos de enfermagem. A AIDS é vista pelos sujeitos do estudo como doença ainda muito estigmatizada socialmente e, também, produto de sua vivência profissional, percebem que os pacientes são vítimas mais freqüentes do preconceito por ser HIV positivo, do que por ter outra infecção: "Sofre-se muito mais preconceito por ser HIV positivo do que por ter hepatite $B$ ".'(fragmento do discurso dos enfermeiros).

É visivel que a AIDS é a responsável pelo desencadeamento das preocupações com os riscos biológicos ocupacionais, não apenas dos estudiosos do assunto, mas também no imaginário do profissional assistencial da saúde. Trecho do discurso médico é ilustrativo: "com o advento da AIDS a gente se preocupou muito com isso".

Não obstante as indicações da literatura de que o risco de se contaminar com o HIV acidentalmente durante o desenvolvimento das atividades laborais que envolvam o contato com sangue e outras secreções seja significativamente inferior a outros vírus, não parece ser essa a crença dos profissionais: "A AIDS é a primeira que a gente pensa. A que a gente está mais suscetivel hoje".

A idéia do risco por parte dos profissionais, desvincula-se, portanto, de análise da realidade epidemiológica em que se encontram e de conhecimentos mais aprofundados acerca da possibilidade da transmissão ocupacional do vírus. Isso faz supor que o imaginário dos profissionais da saúde, exceções que devem obviamente ser feitas aos mais afeitos ao assunto, no caso específico da doença AIDS, aproximase mais do que seria de se cogitar, ao imaginário leigo. 
Trecho compilado de pesquisa de RISCADO(1998), fragmento este no qual o próprio autor desvela os seus próprios sentimentos nos seus primeiros contados com pacientes portadores do HIV dá uma boa medida de nossa assertiva:

"Como se compreendia um professor universitário, com atuação em hospital-escola, psicólogo, educador da área de saúde, passar por conflitos que se situavam na linha do (des)conhecimento?... Surpreendiamo-nos, muitas vezes, frente aos pacientes com AIDS, com os nossos conflitos, com destacado material onírico e comportamentos paranóico-obsessivos... Não faltavam os constantes, demorados e completos banhos, assim como o constante uso do álcool e detergentes para as assepsias pessoais"

Voltando aos nossos discursos, a discriminação, por outro lado, tanto é vista como um problema para os profissionais da saúde, como parece natural para eles próprios. Vejamos: "O HIV é aterrorizante, porque tem todo o problema da doença e da discriminação. Até provar que 'focinho de porco não é tomada', como você fica, como você fica?" (fragmento de discurso médico).

Para fins de refletirmos que a problemática do medo da AIDS no ambiente hospitalar não se constitui em elemento isolado tomemos as observações de SILVA (1997), que em estudo com enfermeiras de hospital especializado em doenças infecciosas, também observou preocupação de algumas profissionais com uma possível contaminação com o HIV durante o trabalho, conforme desvela trecho de entrevista aqui reproduzido: "[..] se eu pegar AIDS aqui, ninguém vai associar às minhas atividades no hospital, as pessoas vão associar à minha vida [...] pois já ouvimos comentários duvidosos em relação às pessoas que se acidentam. Para as pessoas sempre vai ficar a dúvida [...] vão associar ao meu comportamento sexual [...] $\dot{a}$ minha conduta".

Parece claro que a hipótese de se contaminar ocupacionalmente remete a um problema entendido pelo profissional como complexo, o de provar que não se adquiriu o vírus de forma "pouco louvável", conforme já insinuado em questões anteriores. 
Observemos que ao lado da AIDS, revela-se neste presente estudo, particularmente no DSC dos auxiliares de enfermagem, também a preocupação com a aquisição ocupacional de outras doenças caracterizadas como de transmissão sexual, a sífilis e os condilomas, especificamente. A frase aqui destacada do discurso reforça a suposição de que o julgamento social têm seu peso na representação social dos medos dos profissionais em respeito as doenças que porventura possam adquirir durante seu exercício laboral:

“...e essa doença também, a sifilis, eu tenho assim um receio de me contaminar com ela. Porque às vezes, quando a gente é contaminada, as pessoas acham assim: Que nada, está saindo com fulano. Já fica imaginando quando é assim uma doença venérea"

Abrimos aqui um parêntese para referir que esse conteúdo vem ao encontro do que afirma DOMINGUES (2001), para quem a AIDS e a sífilis se assemelham, no que se refere ao despertar medos e preconceitos, na medida da mesma representação social de vínculo das duas patologias a comportamentos considerados desviantes.

As referências discriminatórias especialmente à AIDS, por outro lado, não são de maneira nenhuma veladas nos discursos aqui estudados, pelo contrário, os sujeitos do estudo lançam mão deliberadamente de conhecimentos truncados que revelam essa discriminação, para ilustrar inclusive a elaboração de uma forma pessoal de "triagem" dos pacientes para a instituição de mecanismo de auto-proteção.

Os discursos dos médicos e dos auxiliares e técnicos de enfermagem são os mais enfáticos. Isto não quer dizer que essa não seja também uma prática das enfermeiras. Elas podem, simplesmente, não tê-la verbalizado.

"Pacientes tatuados [...] todo tatuado, faz uso de drogas". "É um horror a tatuagem". "Paciente tatuado, é duas, três luvas" (fragmentos de discurso médico).

"Porque chega um paciente emagrecido, raquitico, a gente logo diz [...] esse cara é aidético. Ai a gente olha a idade, se está com jeito de droga, a gente olha 
logo a pele dele se tem marca, tatuagem, mancha, chama muito a atenção" (fragmentos de discurso de auxiliar de enfermagem).

Observemos que particularmente esse último fragmento traz em seu bojo a idéia equivocada de que o portador do vírus HIV ou mesmo o doente de AIDS, tem determinadas características que o destacaria dentre os demais usuários dos serviços de saúde. Em suma, os discursos dos profissionais deixam escapar conteúdos que ressaltam o próprio preconceito que eles têm da doença, e também revelam sinais de que a informação, até muito pouco tempo difundida pelos meios de comunicação social, de que somente algumas pessoas estariam expostas aos riscos de contaminação e, portanto, poderiam se infectar, ainda não está completamente superada. Essa observação coincide com dados de TURA (1997), em estudo desenvolvido no Rio de Janeiro, cujos sujeitos do estudo foram jovens estudantes do segundo grau.

No caso aqui em apreço, a situação nos parece de maior gravidade, pois ainda que o fragmento mais contundente tenha sido extraído de fala de profissional de formação técnica, ainda assim trata-se indubitavelmente de discurso de profissional da área de saúde. Porém esse tipo de sentimento é explicado por PAULILO (1999), que refere que a AIDS, fortemente associada ao homo e bissexualismo no passado, passa na seqüência a incorporar outras imagens como a das prostitutas e usuários de drogas injetáveis.

De acordo com CZERESNIA (1997), o próprio conceito epidemiológico do risco foi utilizado de início para definir os grupos atingidos pela doença, inquirindo-se prováveis exposições. Primeiramente descrita em homens homossexuais, a identificação de "fatores de risco" tornou-se ligada ao seu "estilo de vida". Para a autora, o próprio termo risco foi utilizado de um modo que reforçou conotações esteriotipadas de grupos sociais marginalizados. Essa característica diluiu-se relativamente depois, uma vez que os dados de notificação da doença indicaram mudanças importantes na evolução do padrão demográfico de sua disseminação. 
Observamos que de acordo com os números do MAP NETWORK (1997), a primeira fase da epidemia envolveu a transmissão sexual do HIV, identificada primariamente entre homens homossexuais; Em uma segunda fase, ocorre um aumento da transmissão através do uso de drogas injetáveis; Já a fase atual é marcada pela tendência de aumento de disseminação heterossexual, acometimento de grupos mais jovens, de maior paridade sexual (chegando a dois casos masculinos para um caso feminino em algumas partes do país), baixo nível educacional dos infectados e maior disseminação em áreas externas aos grandes centros urbanos.

Por outro lado, o advento dos anti retrovirais e o melhor acesso às medicações pelos indivíduos infectados, também provocou mudanças na "fácies típica" do doente de AIDS que atualmente têm a vida praticamente normal, contrariamente ao que crê o discurso ora analisado: "Porque chega um paciente emagrecido, raquítico, a gente logo diz [...]".

Em síntese, apreende-se dos discursos aqui sob análise, ou pelo menos de parte deles, haver um certo descompasso entre uma realidade que vem se modificando e o domínio desse conhecimento pelos profissionais de assistência à saúde. Essa observação, é absolutamente não generalizável, mas ainda assim, reveste-se de importância na medida em que expõe a problemática da atualização profissional e pode trazer, afora outras, conseqüências relativas à adoção de medidas de autoproteção.

Embora não se encontre na literatura muitos estudos acerca do conhecimento de profissionais da área da saúde a respeito da doença em apreço, exceto uma ou outra pesquisa pontual direcionada a aspectos específicos, que fogem ao escopo do que aqui se discute, pesquisas realizadas com estudantes universitários dessa mesma área, apontam, todavia, para um nível elevado de conhecimentos acerca da AIDS e práticas não condizentes com o alto grau de conhecimento, ressaltando-se inclusive algumas atitudes discriminatórias na assistência ao paciente portador do HIV/AIDS (DESSUNTI 2002). 
Os mesmos trabalhos revelam não haver diferenças significativas entre o conhecimento acerca da doença entre os estudantes das primeiras e das últimas séries dos cursos (DESSUNTI 2002; RISCADO 1998), indicando, para os autores, que a própria universidade não vem contribuindo satisfatoriamente com a difusão do conhecimento e prevenção da doença. RISCADO, por exemplo, demonstra que as informações acerca da AIDS são obtidas pelos estudantes da área de saúde, preponderantemente através da mídia.

Confirmando essa constatação LIMA et al. (2000), em pesquisa sobre o ensino das DST/AIDS em Curso de Medicina, concluem que o assunto é abordado no referido curso, de forma insatisfatória e limitado a seus aspectos clínicos, em detrimento dos aspectos epidemiológicos, psicossociais e culturais.

Estudo de RODRIGUES (2000), desenvolvido com cirurgiões dentistas, traz dado revelador senão de desconhecimento sobre a infecção aqui em discussão, pelo menos das precauções universais, ao demonstrar que $83 \%$ dos sujeitos da pesquisa admitem utilizar procedimentos especiais para atender portadores do vírus. A autora do trabalho cita ainda que, ao contrário do que se poderia supor, os desempenhos mais desfavoráveis relativos ao assunto, são os dos profissionais de faixas etárias mais jovens, ao que ela atribui à possibilidade de que os profissionais com maior tempo de exercício talvez invistam mais em cursos de atualização do que os demais, face ao alcance de condições financeiras mais consolidadas. Os profissionais com tempo mais ampliado de exercício profissional (maior que vinte anos), todavia, apresentam também desempenho bastante modesto em relação ao assunto, justificado, pela autora, pela possibilidade de que, estando mais próximos à aposentadoria, esses dentistas investiriam menos em atualizações.

De acordo com a mesma autora, percebe-se ainda ,quando da realização das entrevistas com os profissionais supracitados, um esforço verbal, retórico dos sujeitos para convencer de que não são incautos e desinformados sobre o assunto em foco. Os conteúdos apresentados, todavia, assevera a pesquisadora, apontam para a incontestável precariedade dos conhecimentos e denotam, com clareza, a insegurança dos profissionais em relação ao novo. 
Ao que indica, também os serviços de saúde não tem colaborado com a modificação de algumas certezas e incertezas dos profissionais neles atuantes acerca de um assunto tão palpitante como é o caso da AIDS. Isso deve trazer, em seu seio, conseqüências para a implementação de medidas de auto-proteção pelos profissionais, durante o desenvolvimento de suas atividades laborais.O próprio discurso ora estudado, que num primeiro momento pode dar a impressão de que as pessoas se cuidam, ampara a constatação de que a assistência pode estar se dando no escuro, quando desconhecidos os diagnósticos dos pacientes. A frase compilada de discurso de auxiliar/técnico de enfermagem mostra bem esse tom: "É tanto que quando tem um paciente que é portador de AIDS, todo mundo fica no maior cuidado, redobra o cuidado e tal e não punciona veia sem luva de jeito nenhum".

\subsection{Sobre os significados da biossegurança}

O assunto biossegurança não desencadeia propriamente um discurso na sua completude por parte dos profissionais atuantes nos hospitais. Em verdade, a questão gera uma certa perplexidade, seguida de ensaios de respostas que enveredam pela tentativa de compreensão etimológica da palavra. Essa averiguação permite-nos afirmar que o tema, pelo menos com esta denominação, não faz definitivamente, parte do repertório dos profissionais.

A dificuldade de emitir juízo acerca do assunto independe, grosso modo, da categoria profissional, se médicos, enfermeiros ou auxiliares e técnicos de enfermagem. É certo, entretanto, que esses últimos expõem mais o seu embaraço em desconhecer o assunto.

Para fins de organização dos conteúdos, agrupamos as falas em torno de duas idéias centrais predominantes, que emergiram para cada uma das categorias profissionais. 
Quadro Síntese - Biossegurança. Essa palavra significa algo para você?

Médicos - Idéias Centrais

\begin{tabular}{|l|l|l|l|}
\hline $\begin{array}{l}\text { Técnicas e equipamentos para a segurança } \\
\text { da vida. }\end{array}$ & $\begin{array}{l}\text { Uma aproximação com a saúde } \\
\text { pública. }\end{array}$ \\
\hline
\end{tabular}

Enfermeiros - Idéias Centrais

\begin{tabular}{|l|l}
\hline Proteção contra infecções. & Proteção no sentido holistico.
\end{tabular}

Auxiliares e técnicos de enfermagem - Idéias Centrais

\begin{tabular}{|l|l|}
\hline Várias idéias. & Condições de trabalho. \\
\hline
\end{tabular}

A idéia de segurança da vida perpassa quase todas as construções discursivas. A resposta da grande maioria dos médicos acerca do significado da biossegurança gravita em torno de procedimentos e meios de se preservar, de assegurar-se, de não contaminar-se com agentes biológicos. Segue abaixo a primeira construção.

Idéia central - Técnicas e equipamentos para a segurança da vida

\section{DSC - Dos médicos}

Biossegurança? Segurança da vida. Viver com segurança na sua vida, no seu trabalho. Trabalhar imaginando que se está exposto. Tratar com o paciente pensando na possibilidade de ele ter uma doença infecto-contagiosa. Ter cuidado com todos os procedimentos e pacientes. Procedimentos, meios, tudo o que se puder utilizar, proceder, implantar para que você se preserve. Assegurar-se de não se contaminar. Segurança para fatores biológicos, embora alguns médicos não acreditem muito nas bactérias. É tudo o que não pode faltar em um hospital. Desde a parte de engenharia até a parte prática mesmo dos cuidados.

Entrevistados $1,2,3,4,5,6,7,8,9,10,11,12,13,14,17,20$.

Observamos que intenta-se uma resposta pouco mais abrangente quando se aborda a questão da engenharia que traz em seu bojo a lembrança da importância dos aspectos da infra-estrutura física hospitalar e chama-nos a atenção mais pelo pitoresco a alusão à biossegurança como "segurança para agentes biológicos" (conceito 
correto) seguida da adversativa "embora alguns médicos não acreditem muito nas bactérias".

Uma segunda abordagem dos médicos tem trânsito na tentativa de aproximação da biossegurança com a saúde pública e com temas, na acepção do profissional, atuais como a ecologia. Faz-se menção a esses assuntos como "coisas 'simples' que poderiam ser feitas (ou pensadas) há anos". Havendo, todavia, ainda muito para ser desenvolvido. Fica a esperança de que chegue com o tempo.

Idéia central - Uma aproximação com a saúde pública

\section{DSC - Dos médicos}

Significa falar em saúde pública, moda no mundo todo: biossegurança, ecologia. De repente se acorda para uma série de coisas. Coisas simples que poderiam ser feitas há muitos anos. É uma coisa que ainda tem muito para ser desenvolvida. Vai chegar com o tempo.

Entrevistados 16,10.

As enfermeiras são mais diretas nos seus conceitos. Descrevem a biossegurança como forma de se proteger de determinados tipos de infecções e ter disponiveis materiais que confeririam essa proteção (equipamentos de proteção individual). $\mathrm{O}$ espirito de liderança conferido pelas atividades gerenciais que desenvolvem aflora quando verbalizam sua responsabilidade de proporcionar à equipe o máximo de proteção e também "cobrar isso dela".

Idéia central - Proteção contra infecções

\section{DSC - Das enfermeiras}

Uma maneira de se proteger de determinados tipos de infecção. Precauções para se evitar contaminação das pessoas. Ter disponivel materiais e ter também a consciencia da necessidade de se proteger a si e aos outros. Proporcionar à equipe o máximo de proteção e, por outro lado, cobrar isso dela.

Entrevistadas: $1,2,3,4,5,6,7,8,10,12,13$ 
Numa segunda perspectiva, o sentido de membro de uma coletividade no trabalho é também realçado pelos enfermeiros. Tenta-se um vôo mais alto para a configuração da biossegurança, ao se traçar um paralelo entre o que se busca, em tese, nas relações com o paciente, o de vê-lo como um todo, para o como a instituição deveria ver os trabalhadores nela engajados, como a antítese de uma máquina, "um ser humano dotado de emoções, sentimentos, necessidades e medos".

Idéia central - Proteção no sentido holístico

\section{DSC - Das enfermeiras}

BIO vem de vida. Assegurar sua vida saudável, não somente na parte fisica, biológica, mas também na parte psicossocial, o todo completo. Temos que ver o paciente como um todo e a instituição tem que ver o funcionário como um todo. $O$ funcionário não é só uma máquina, mas um ser humano dotado de emoções, sentimentos, necessidades, medos. As instituições não trabalham com isso, trabalham na parte do ser humano enquanto mão de obra, enquanto retorno.

Entrevistados 9,11.

Todavia, não é assim, nessa idealização, que as instituições vêem seus trabalhadores, chega-se à conclusão, conforme o fragmento aqui transcrito desvela: "As instituições não trabalham com isso, trabalham na parte do ser humano enquanto mão de obra, enquanto retorno".

Os auxiliares e técnicos de enfermagem, por outro lado, na sua grande maioria, não têm idéia a que o tema biossegurança se refere. As tentativas de respostas vão desde alguma aproximação etimológica como "biologicamente seguro" e "segurança da vida", até uma disparidade vernacular: "Bio significa grande?", passando por um significado tênue de proteção: "Alguma coisa que te protege, que te dá proteção?" Ressaltamos ainda um sentido passivo que compreendem dessa mesma proteção: " $E$ uma maneira das pessoas procurarem te aconselhar, será que é isso?" 
Idéia central - Várias ou nenhuma idéia

\section{DSC - Dos auxiliares e técnicos de enfermagem}

Biossegurança? Nunca ouvi falar. Imagino que seja segurança de vida. Bio significa grande? Segurança total? Biologicamente seguro? Bio-vida, segurança, pronto, segurança de vida. Alguma coisa que te protege. que te dá proteção. É uma maneira das pessoas, procurarem te aconselhar. Será que é isso? Para se proteger ?Eu já ouvi falar essa palavra, mas garanto que eu não entendo nada não. Segurança minha? Se eu sou insegura? Já ouvi falar de segurança,mas bio, não. É ter segurança no que faz, porque se você fizer uma coisa com medo [...] não ter segurança no que faz [...] Ter o máximo de cuidado.Porque a gente não ter segurança...Ai fica dificil a gente ir para a frente. A gente tem que ter segurança para transmitir para o paciente.

Entrevistados $\quad 1,2,3,4,5,6,9,10,11,12,13,14,15,17,18,20,21,22,24,25,26,27,28$,
$29,30,31,32,33,34,36,38,39,41$.

Um último discurso, esse de uma minoria dos auxiliares e técnicos de enfermagem, aproxima-se um pouco mais do sentido da biossegurança.

Idéia central - Condições de trabalho

\section{DSC - Dos auxiliares e técnicos de enfermagem}

Se proteger, ter condições de trabalho. Nada mais é que promovermos a segurança dos profissionais que trabalham na área de saúde ou mexem com produtos biológicos. São as medidas que a gente tem que tomar para a nossa segurança, o uso de luvas, máscaras, aventais. Foi um pouquinho de biossegurança que não tive quando encapei a agulha e é errado, mas o reflexo foi mais forte.

Entrevistados 16,19,23,35,40.

Interessante notarmos que essa última construção traz muito de um senso prático de quem, na labuta diária, sente na própria carne as agruras da vulnerabilidade aos riscos travestidos nos acidentes $\mathrm{e}$ às suas possiveis conseqüências: "Foi um 
pouquinho de biossegurança que não tive quando encapei a agulha e é errado, mas o reflexo foi mais forte".

Cumpre ressaltarmos que nossos achados acerca dos significados de biossegurança para os profissionais de saúde, aqui circunscritos aos médicos, enfermeiras e auxiliares e técnicos de enfermagem, guardam confluência com os resultados da pesquisa de SOUZA (2001), ainda que considerando que os estudos têm diferentes desenhos metodológicos. A autora, argüindo 134 enfermeiros e 92 auxiliares de enfermagem, verificou que $21,7 \%$ deles (49 sujeitos) desconhecem do que se trata a biossegurança. Todos afirmam nunca ter sequer ouvido a palavra em pauta.

Chama ainda a atenção da autora que dentre os entrevistados que confirmam sua total ignorância sobre o assunto, ou pelo menos da terminologia em questão, figuram não apenas profissionais de nível médio, mas também enfermeiros, o que a leva a deduzir que a formação profissional vem se fazendo de forma lacunar, independente do seu grau.

A mesma pesquisadora depreende algumas aproximações com o conceito de biossegurança, embora não completamente estruturados, cujo enfoque maior se dá na sua compreensão, enquanto proteção individual do trabalhador através do uso de equipamentos $(21,7 \%$ dos respondentes) (SOUZA 2001).

Aqui registramos três exemplos retirados do seu trabalho que guardam semelhanças com os nossos dados:

"Conjunto de medidas que visam a proteção do profissional, compreende a informação e a utilização dos equipamentos de Proteção Individual" (Enfermeira);

"Medidas adotadas para se proteger de contaminação e acidentes que possam causar algum dano durante o trabalho" (Enfermeira);

"Relacionado com nossa proteção no trabalho, uso de equipamentos de acordo com procedimento realizado" (Auxiliar de Enfermagem). 
Em contrapartida, um grupo menor de entrevistados no mesmo estudo, 11 profissionais $(4,9 \%)$, todos enfermeiros, avançou um pouco mais, segundo a autora, na definição do termo, enfocando não apenas a proteção do profissional, mas também a do cliente atendido nos serviços de saúde e uma das entrevistadas abordou o tema também como forma de garantir a qualidade no serviço.

RODRIGUES (2000), em estudo sobre as representações sociais de cirurgiões dentistas acerca da utilização de medidas de biossegurança, detectou que chamados à relacionar as palavras que mais se associavam ao tema em pauta, a maioria das evocações recaiu sobre os campos semânticos que seguem com suas respectivas freqüências: esterilização (201), prevenção (121), luvas (54), máscara (49), saúde (44) e óculos(43).

Procedendo à análise dos dados, a autora explica que, embora se observe a existência de um repertório cognitivo que remete aos primórdios da biossegurança ou, ainda, do tradicional controle de infecção, os sujeitos do estudo começam a re-significar essas cognições, a medida em que o tema saúde também aparece. Complementa ainda que, analisando, adicionalmente, as falas dos entrevistados, percebe-se que essas são enriquecidas com significações novas inerentes ao conceito ampliado de biossegurança. Enfim, conclui que percebe-se que começa a acontecer, ao mesmo tempo, uma mudança de significado, em função da história de vida, das pressões sociais e institucionais e das experiências individuais sem, no entanto, se desprezar os valores mais tradicionais.

De outro lado, SOUZA (2001), expressa que em seu estudo, a surpreendeu o fato de nenhum entrevistado ter relacionado a biossegurança com aspectos do meio ambiente, o que a faz supor que, por uma questão cultural, essa problemática não têm sido amplamente discutida, nem mesmo nos órgãos formadores.

Concordamos com a autora supracitada quando refere que os dados de sua pesquisa e, permitimo-nos incluir, também os nossos, colocam à prova a questão da atualização profissional levando-se em conta que, por se tratar a biossegurança em temática de discussão mais recente, seria admissivel não ter sido objeto dos aparelhos 
de formação, pelo menos para aqueles profissionais que se graduaram/formaram antes que as primeiras preocupações com as exposições ocupacionais fossem suscitadas, mas dificilmente se justifica o fato de não ter se constituído em alvo de programas de educação em serviço.

Essas observações permitem-nos argumentar que os sujeitos do estudo de SOUZA, exercem suas atividades profissionais em hospital de ensino que, mesmo que abstraídas todas as dificuldades porque passam as instituições públicas de ensino nacionais, deve se constituir em locus privilegiado no que toca ao acesso às informações atualizadas, ou pelo menos realidade em tese diferenciada.

Isso não justifica por si só, a alienação detectada nas falas de boa parte de nossos entrevistados no que se refere à compreensão da biossegurança, posto que vivemos numa era cujo acesso às informações caracteriza-se por ser mais democratizado do que nunca o foi, pelo menos para as parcelas profissionalizadas, a exemplo dos médicos e dos próprios enfermeiros, mas nos faz supor que eles integram um contexto provavelmente mais generalizado.

Por fim, inferimos que o tema biossegurança parece distante de se configurar em emblema que guie o discurso e, possivelmente, a prática dos profissionais da saúde atuantes em hospitais. Pelo menos daqueles que emprestaram sua voz em resposta às nossas indagações. 


\section{CONSIDERAÇÕES FINAIS}

Posta a ausência de um modelo de avaliação institucional que leve em conta características que contribuam para a configuração de um meio mais seguro de atuação profissional frente aos riscos biológicos e da tese de que as práticas profissionais relativas à auto-proteção dependem também de aspectos estruturais das instituições, acreditamos que o estudo possa lançar alguma luz sobre a problemática da biossegurança .

A partir das questões que nortearam o estudo, quais sejam, como se constitui a estrutura relativa à biossegurança para agentes biológicos nos hospitais; como se dá a incorporação de medidas de auto-proteção por parte dos trabalhadores e, ainda, quais os discursos dos profissionais da saúde engajados nesses mesmos locus, pudemos construir um quadro, passivel de servir de base para o vislumbre de um cenário que possivelmente se faça mais abrangente.

Importante, contudo, ressaltarmos que trata-se de um estudo exploratório e consequentemente demandante de novas investidas.

Ademais, a própria temática da biossegurança constitui-se excepcionalmente atual e multifacetada, o que dificulta a circunscrição de elementos que devam ser levados em conta, quando do intento de se atingir em particular o primeiro objetivo do trabalho. Daí, a dificuldade em criteriarmos itens que possam, no seu conjunto, permitir afirmar que determinado agrupamento de hospitais ou mesmo determinada instituição apresenta-se mais ou menos bem provida de adequada estrutura relativa ao assunto. Observamos que o próprio debate acerca da qualidade mostra-se ainda distante de esgotar todas as possibilidades.

Permitimo-nos afirmar, entretanto, face aos resultados encontrados, que a precariedade das instituições estudadas, no que concerne à biossegurança, é evidente. Ilustrativo é que, tomando-se as médias da presença de itens considerados para fins do estudo, observamos que nenhum dos vinte e cinco hospitais analisados alcança 
indice de assertivas de $70 \%$ de presença de itens. Apenas duas instituições $(8 \%)$ aproximam-se dessa média, três outras (12\%) apresentam percentagens entre 53 e $44 \%$ de presença de itens e as demais (80\%), não dispõem nem de $40 \%$ dos itens em pauta.

Contudo, evidenciam-se diferenças quando os hospitais são agrupados por porte, com tendência de aumento da presença dos itens em proporção do tamanho dos hospitais e também por características jurídico-financeiras dos nosocômios, apresentando melhores resultados os hospitais filantrópicos, seguidos dos privados e, por último, dos públicos.

Conquanto na análise da dispersão dos hospitais tenhamos evidenciado, não obstante as diferenças supra mencionadas, que há uma tendência de que os hospitais distanciem-se de uma situação na qual todos os pontos aqui considerados como importantes estejam presentes e aglomerem-se num amálgama razoavelmente indiferenciado, observamos, ainda assim, que os hospitais pequenos e particularmente os públicos mostram-se, no geral, os mais deficitários na matéria aqui investigada.

Convém ressaltarmos, todavia, que esses hospitais, além do diminuto número de leitos, apresentam também outras características como a especificidade de atendimentos de casos menos complexos, o reduzido número de profissionais neles atuantes e outras fragilidades. Esses elementos podem contribuir para uma maior precariedade em termos também da estrutura concernente ao objeto em apreço.

Essas observações nos impelem a considerar que instrumentos específicos devam ser levados em conta quando do intento de se empreender descrições comparativas entre serviços hospitalares.

Da análise da presença item a item, depreendemos fraco desempenho dos hospitais no geral, quanto à existência de normas escritas, à realização de treinamentos específicos dos componentes da equipe, à baixa presença de registros institucionais relativos a medidas de biossegurança, o mesmo ocorrendo com temas afetos à saúde dos trabalhadores. Por outro lado, embora tenha havido referência em $76 \%$ das 
instituições à implementação de isolamentos para pacientes com tuberculose, nenhum hospital dispõe de acomodações apropriadas para isolamento de pacientes, item necessário à uma adequada estrutura de biossegurança em hospital.

Concernente ao estudo da incorporação de práticas de autoproteção pelos profissionais, que aqui circunscrevemos às venipunções à título de análise do processo, observamos diferenças nas performances entre os três hospitais investigados.

Não podemos deixar de atentar para o fato de que, numa análise cruzada, os dois hospitais que obtiveram os melhores resultados concernente ao estudo da estrutura (Os hospitais D e L), apreenderam, na análise da incorporação prática das medidas de auto proteção (especificamente na lavagem das mãos antes e após os procedimentos de venipunção, bem como o próprio emprego de luvas), resultados mais modestos que o hospital T (o quinto em ordem decrescente no referente a presença em termos percentuais do conjunto de itens analisados).

Os resultados das adesões às medidas relativas ao não re-encape de agulhas, bem como o imediato descarte do apetrecho após o uso, ao contrário, mostraram-se proporcionais ao desempenho das três instituições no atinente à presença do conjunto de itens considerados para a análise estrutural. Observamos ainda que no estudo ponto a ponto dessa mesma estrutura nos hospitais D e L, estavam presentes normas escritas sobre as precauções padrão e foi registrada a ocorrência de treinamentos específicos para as respectivas normas. No hospital $\mathrm{T}$, embora a referência ao treinamento tenha sido positiva, a instituição não dispõe de normas escritas para o assunto em foco.

Ainda que caiba registrar que o estabelecimento de relações de causa - efeito fuja aos propósitos deste trabalho, devemos referir que os resultados supramencionados levam a crer que um indicativo de adequação estrutural (aqui no caso específico, a presença de normas escritas para as precauções padrão), concorre para a realização, com correção, de determinadas práticas por parte dos profissionais. ( $O$ descarte 
imediato de agulhas, bem como o seu não re-encape, mais freqüentemente empregados nos hospitais D e L, constituem-se em exemplos ilustrativos).

Verificamos ainda diferenças nas aderências às recomendações quando comparados os diferentes setores hospitalares, diversidades essas que acreditamos relacionaremse preponderantemente aos distintos processos de trabalho.

Os achados vistos no seu conjunto, nos levam a inferir, adicionalmente, que à construção de um adequado aparato de biossegurança, contribuem elementos estruturais e também detalhes relacionados às especificidades do fazer humano. Base que podemos tomar para endossar nossa suposição é a tendência à maior adesão à lavagem das mãos após a realização de procedimentos de acesso venoso, pelas profissionais do sexo feminino. E, de igual modo, à maior adesão à lavagem prévia e após o mesmo procedimento quando do trato com infantes.

Outro aspecto que merece ser relembrado é o da observação de maior freqüência de lavagem das mãos, previamente à realização de procedimentos de acesso venoso, entre os profissionais com tempo de atuação na área da saúde entre cinco e dez anos do que entre os recém formados e aqueles com mais de dez anos de trabalho.

Ao nosso ver é possível que esses últimos resultados relacionem-se, conforme já discutido, embasando-nos em literatura pertinente, a um maior sentimento de segurança demonstrado pelos profissionais com tempo intermediário de formação quando comparados aos recém formados e tendência a posturas mais inadequadas por parte daqueles que tiveram formação anterior ao advento das precauções universais/padrão.

Embora absolutamente não generalizáveis, os resultados indicam que esses detalhes que acreditamos estarem relacionados a particularidades do fazer humano, merecem atenção.

Daí o relevo do estudo das percepções dos profissionais atuantes nos hospitais sobre temas relativos à biossegurança. Podemos afirmar que os Discursos dos Sujeitos Coletivos, mostraram, na justa medida, os sentidos atribuídos ao contaminar-se 
/preservar-se por parte dos profissionais entrevistados. Sentidos que se diferenciam mais no contingenciamento do fazer diário dos profissionais do que quando tomados na sua inserção nos diferentes hospitais, conquanto não tenha se constituído em objeto do estudo a apreensão dos discursos segmentando-os de acordo com as diferentes instituições.

Isso nos leva a pensar que o discurso espelha a precariedade estrutural praticamente generalizada dos hospitais no que se refere à biossegurança. Refletimos também que a própria representação social dos sujeitos acerca da temática em foco, notadamente marcada por importante dose de alienação, conforme bem expressam as falas, deve ter suas influências sobre essa mesma estrutura.

Ora, indagamos, não parece sintomático que o reconhecimento precoce de pacientes com quadros indicativos de tuberculose, por exemplo, enquanto forma de proteção ocupacional para agentes biológicos, não faça parte das rotinas hospitalares, nem tampouco dos discursos dos profissionais?

Não se pode dizer o mesmo da referência à vacinação contra a hepatite $B$ enquanto meio importante de proteção profissional, quase ausente dos discursos dos profissionais e também prática pouco freqüente (pelo menos no que concerne à uma sistemática) nos hospitais?

Interessante notarmos que os discursos dos profissionais entrevistados confluem, quase todos, para a verbalização do risco diuturno a que estão submetidos. A concepção de proteção centra-se no uso de EPIs, notadamente das luvas. Outras medidas são muito menos lembradas.

Por outro lado, embora razoável parte dos conteúdos discursivos relacionem a autoproteção como rotina inerente às atividades desenvolvidas, nos parece escapar, de boa parte dos discursos, que essa rotina é tanto mais "rotineira" conforme os quadros ou nosologias que os pacientes apresentam. 
É freqüente a expressão do temor a doenças estigmatizantes e estigmatizadas pelos próprios profissionais, conforme desvelam as falas. A AIDS mostra toda sua força nos imaginários e transcende sob a forma de discursos recorrentes.

Mas percebe-se, em contrapartida, que a biossegurança não se constitui em tema corriqueiro no repertório dos trabalhadores, independentemente da sua categoria profissional.

Assim é que, de todo o exposto, permitimo-nos supor que os resultados do presente estudo, admite alocá-lo na concepção teórica de que a sociedade é percebida como fruto de um processo estreitamente relacionado do indivíduo e da sociedade e o comportamento humano, que tem como dado principal o ato social, é concebido não só como comportamento "externo", observável, mas também como atividade "encoberta" do ato. (Haguette,1995).

Em outras palavras, os seres humanos agem com relação ao objeto com base no significado que este tem para eles e o significado deste objeto é derivado da interação entre atores sociais, ou seja, esses significados são modificados através de um processo interpretativo desenvolvido pelas pessoas em interação.

Isso posto, pensamos que a discussão acerca da biossegurança deva ser tanto técnica quanto ética. Isto nos referindo a ética axiológica moderna, conforme definida por MARQUEZ(1996) "Ciência que por meio de valores trata de averiguar a essência da moralidade, uma ciência prática porque estuda a natureza e as propriedades da moralidade dos valores".

Fazer ou não fazer, são decisões presididas pela construção que o sujeito tenha do dever fazer, que por sua vez decorre do dever ideal que se baseia na essência dos valores e mobiliza a vontade do sujeito em ação. Ora, a existência das normas, das razões lógicas para os procedimentos que evitam/reduzem os riscos biológicos a que estão expostos, não é o bastante para fazê-los atentos a essas regras. É necessário que os sujeitos tenham como valor a preservação da vida, da qualidade da vida (da sua própria vida). Não importa se isso resultará em mais trabalho ou mais complexidade do trabalho, que é dele ou de outrém. São, pois, o sentido e a força que tenham sido 
construídos como amálgama do dever fazer que orientam o juízo de valor necessário à tomada de decisão sobre "como deve ser feito", reduzindo os riscos. É, então, uma atitude de compromisso consigo mesmo e com seu juízo social que preside a tomada de decisão de estar atento às regras.

Arriscamos, assim, algumas recomendações que em verdade se constituem mais em reflexões a que nos levam o estudo. A primeira delas e possivelmente a de maior relevância é a de que esforços devam ser empreendidos para que a biossegurança perpasse toda uma nova forma de pensar e agir na área da saúde. Que a matéria ultrapasse a simplista dimensão do uso de meios para a prevenção de acometimentos por agentes biológicos e que seja incorporada como valor, enquanto forma de comportamento seguro ou de uma ação ética.

Para MARQUEZ(1996), a ação ética não se origina da sensibilidade do homem para o valor, mas da vontade devidamente orientada pelo juízo de valor, que tem fundamentos axiológicos e lógicos e, portanto, depende de uma construção tanto afetiva quanto cognitiva.

Daí, nossa segunda recomendação, a de que os aparelhos formadores de recursos humanos em saúde incorporem nos conteúdos de ensino a biossegurança e que os serviços de saúde, em particular os hospitais, estruturas de ensino e aprendizagem por excelência, não descuidem da educação em serviço dos profissionais neles atuantes, relativamente ao assunto em pauta. Redundante ressaltar que o tema é pertinente a todos os profissionais da saúde, independentemente de sua categoria ou posto.

E, por fim, que seja dada atenção pelos formuladores de políticas, à necessidade de uma análise de qualidade das instituições hospitalares, que leve em conta o cuidado também dos seus trabalhadores. Nunca é demais relembrar que as debilidades estruturais dos hospitais nacionais, salvo as exceções de praxe, acumulam-se no curso do tempo. Há que haver um meio termo entre a pulsão tecnológica que torna cada vez mais encarecida a assistência e um tratamento condigno tanto para os usuários quanto para os trabalhadores hospitalares. 
Dentre essas políticas arvoramo-nos a elencar a necessidade de uma definição clara de uma estrutura mínima de biossegurança nos hospitais. Definição esta, construida por especialistas em controle de infecções, profissionais da área da saúde do trabalhador e em bioética e que leve em conta a diversidade da realidade dos hospitais brasileiros.

Recomendamos ainda o estabelecimento de uma política mais arrojada de divulgação de informações atualizadas, principalmente para aqueles serviços hospitalares e seus profissionais que têm sabidamente maiores dificuldades de acesso aos meios mais especializados. Também uma vigilância mais sistemática, pelos órgãos de direito das condições de funcionamento dos hospitais .

Não podemos nos furtar de sugerir, por último, que estudos outros sejam empreendidos, de sorte a permitir confrontação dos dados e aprofundamento de questões aqui não respondidas, com vistas à busca permanente de colaboração com a melhoria da qualidade da assistência hospitalar e da vida dos profissionais atuantes neste locus que desperta tantos sentimentos - bons e maus - o hospital. Este ambiente de trabalho que se concentra no cuidar, sem entrarmos aqui em discussões mais aprofundadas acerca do próprio conceito de cuidado, porém, no cuidar, conforme cita SOUZA(1999), apenas "dos outros". 


\section{REFERÊNCIAS BIBLIOGRÁFICAS}

Adegboye AA et al.Glove utilization and reasons for poor compliance by health care workers in a Nigerian teaching hospital. Tropical Doctor. 1997. 27:93-97.

Ahmad FK et al. The use and failure rates of protective equipment to prevent blood and bodily fluid contamination in the obstetric health care worker. Obstetrics $\&$ Gynecology $1998.92(1): 131-136$.

Akduman $\mathrm{D}$ et al. Use of personal protective equipment and operating room behaviors in four surgical subspecialties: personal protective equipment and behaviors in surgery. Infection Control and Hospital Epidemiology $1999.20(2): 110-123$.

Almeida Filho AJ de. Liberdade e compromisso no agir ético do enfermeiro frente a situações de risco de contaminação. Rio de Janeiro; 1999. [Dissertação de mestrado - EEAN/UFRJ].

[APCIH] Associação Paulista de Estudos Controle de Infecção Hospitalar. Precauções e Isolamento. São Paulo;1999. 50p.

Araújo GA, Lacerda A. Indicadores de causalidade de exposição ocupacional a sangue e outros fluidos corpóreos em equipe de enfermagem de um serviço de emergência. São Paulo; 1997. [Monografia Curso de Graduação- Escola de Enfermagem - USP].

Ayub EBS et al. Abordagem Integrada das Técnicas de Isolamento. In Fernandes AT. Infecção hospitalar e suas interfaces na área de saúde. São Paulo: Atheneu; 2000. p.1020-1025. 
Bahia. Secretaria da Saúde do Estado da Bahia. Portaria 711, de 07 de março de 1996: Normaliza medidas de biossegurança e precauções de isolamento. Diário Oficial do Estado da Bahia, Salvador, 09 e 10 de março, ano LXXX, n. ${ }^{\circ} 16172$ e 16173.

Bahia. Secretaria de Saúde do Estado da Bahia. Superintendência de Regulação, Atenção e Promoção de Saúde/Diretoria de Assistência a Saúde/ Coordenação de Gestão da Qualidade e Avaliação Tecnológica: Padrões de qualidade da assistência para auto-avaliação hospitalar com foco no controle de Infeç̧ão Hospitalar - Portaria 1083; 2001.

Baley M. Occupational HIV infection risk. Lancet. 1990. 335(8697):1104-5.

Barbosa LMM. Glossário de Epidemiologia e Saúde. In: Roquayrol MZ, Almeida Filho N. Epidemiologia e saúde. $5^{\text {a }}$ ed. Rio de Janeiro: Medsi. 1990. 523-559.

Becker MM et al. Noncompliance with universal precautions policy: Why do phisicians and nurses recap needles? American Journal of Infection Control. 1990; 18(4): 232-39

Beekmann SE et al. Hospital bloodborne pathogens programs: Program characteristics and blood and body fluid exposure rates. Infection Control and Hospital Epidemiology. 2001.22(2):73-82.

Beltrami EM et al. Risk and management of blood-borne infections in Health care workers. Clinical Microbiology Reviews. 2000 13(3): 385-407.

Benatti MCC. Acidente do trabalho em um hospital universitário: um estudo sobre a ocorrência e os fatores de risco entre trabalhadores de enfermagem. São Paulo;1997. [Tese de Doutorado - USP]. 
Brasil. Ministério do Trabalho e Emprego. Portaria 3.214 de 08/06/78: NormasRegulamentadoras. www.mte.gov.br/temas/segsau/legislação/normas.

Brasil. Ministério da Saúde. Secretaria Nacional de Ações Básicas de Saúde. Normas e padrões de construções e instalações de serviços de saúde. $2^{a}$ ed. Brasília(DF): Centro de Documentação do Ministério da Saúde; 1983. [Série A: Normas e Manuais Técnicos,3].

Brasil. Ministério da Saúde - Implicações éticas da triagem sorológica do HIV. Brasília. 1993. p.1-28.

Brasil. Ministério do Trabalho e Emprego. Portaria 24 de 29/12/94a. www.mte.gov.br/temas/segsau/legislação/portarias/199 .../port 24.asp/Ação.

Brasil. Ministério do Trabalho e Emprego. Portaria 25 de 29/12/94b. www.mte.gov.br/temas/segsau/legislação/portarias/199.../port 25.asp/Ação.

Brasil. Ministério da Saúde. I Consenso Brasileiro de Tuberculose - Coordenação Nacional de Pneumologia Sanitária. Brasília(DF); Jornal de Pneumologia. 1997 nov-dez.23(6).

Brasil. Ministério da Saúde. Portaria 2.616. Diário Oficial da União. 12/05/1998.

Brevidelli MM. Exposição ocupacional ao vírus da AIDS e da Hepatite B: Análise da influência das crenças em saúde sobre a prática de reencapar agulhas. São Paulo. 1997. [Dissertação de mestrado - EEUSP].

Brito RC. Resistência às drogas anti-tuberculose das cêpas mycobacterium tuberculosis isoladas de pacientes atendidos em hospital geral de referência para tratamento de AIDS no Rio de Janeiro. Rio de Janeiro; 1998 [Dissertação de Mestrado - UFRJ]. 
Cardo D. Absorção de Tecnologia x Mudanças de Comportamento [Palestra proferida no III Congresso Pan-Americano, VIII Congresso Brasileiro e I Congresso de Odontologia de Minas Gerais - Controle de Infecções e Epidemiologia Hospitalar; 2000 nov; Minas Gerais, Brasil].

Carvalho TFA et al. Hepatite B: perfil de proteção em estudantes dos Cursos de Medicina, Odontologia e Enfermagem da UFPE. Revista IMIP 1998 ; 12(2):30-3.

[CDC] Centers for disease Control. Isolation techniques for use in hospitals. US Government Printing office.1975; 76:8314.

[CDC] Centers for Disease Control. Recommendations for preventing transmission of infection with human $\mathrm{t}$ - lymphotropic virus type III/limphadenopathy - associated virus in the workplace. MMWR 1985; 34: 681-95.

[CDC] Centers for Disease Control. Update: Universal precautions for prevention of transmission of human immunodeficiency virus, hepatitis $B$ virus and other bloodborn pathogens in health care settings. MMWR 1988, 37:377-88.

[CDC] Centers for Disease Control. A strategic plan for the elimination of tuberculosis in the United States. MMWR 1989; 38(5-3):1-25.

[CDC] Centers for Disease Control and Prevention. Guidelines for preventing the transmission of mycobacterium tuberculosis in health-care facilities. 1994; 43(RR13):1-133.

Celentano DD et al. Diffusion and adoption of CDC guidelines for the prevention and control of nosocomial infections in US hospitals. In: Infection Control. 1987 8(10):415-423. 
Cervantes C. Hepatite B - Perfil de um patógeno traiçoeiro. Laes Haes. 1996; 18(103):74-6.

Chohfi $M$ et al. O Virus HIV e a cirurgia. Revista de Ciências Médicas PUCCAMP, Campinas, 1995. 4 (2): 55-61.

Cohn A et al. Acidentes de trabalho: uma forma de violência. São Paulo: Brasiliense. Cedec. 1985.

Corser WD. Occupational exposure of healthcare workers to bloodborn pathogens. AAOHNJ. 1998. 46(5):246-52.

Couto RC e Nogueira J M. História do controle de infecção e a situação brasileira In Couto et al. Infeção Hospitalar - Epidemiologia e Controle. Rio de Janeiro : Medsi; 1997. p.1-4.

Cruz C. D. Programa GENES; aplicativo computacional em genética e estatística. Viçosa, UFV, 1997, 442p.

Czeresnia D. Do contágio à transmissão: ciência e cultura na gênese do conhecimento epidemiológico. Rio de Janeiro:Fiocruz;1997, 120p.

Daugherty JS et al. Prevention and control of tuberculosis in the 1990s. Nurs Clin North Am;1993. 28(3):599-611.

De Fillipo $\mathrm{V}$ et al. A universal precautions monitoring system adaptable to any health care department. American Journal of Infect Control. 1992. 20(3):159-63.

Dejoy DM et al. A work systems analysis of compliance with Universal Precautions among Health care works. Health Education Quarterly; 1996 v.23(2):159-174. 
Dejours C. A loucura do trabalho: estudo da psicopatologia do trabalho. São Paulo: Cortez. 1992. 168p.

Dessunti EM. Fatores Psicossociais e comportamentais associados ao risco de DST/AIDS entre estudantes da área de saúde da Universidade Estadual de Londrina. São Paulo; 2002 [Tese de Doutorado - FSP-USP].

Domingues SCA. Representação social da AIDS entre médicos de Vitória/ES. Vitória-ES. 2001 [Dissertação de mestrado - UFES].

Donabedian A. Criteria and standards for quality assessment and monitoring. Qual Rev Bull 1986. p.99-108.

Evanoff $B$ et al. Compliance with universal precautions among emergency department personnel caring for trauma patients. Annals of Emergency Medicine.1999 February; v.33(2):160-165.

Fernandes AT. As bases do hospital contemporâneo: a enfermagem, os caçadores de micróbios e o controle de infecção. In: Fernandes AT. Infecção hospitalar e suas interfaces na área de saúde. São Paulo: Atheneu; 2000. v.1, p.75-127.

Fernandez PF. La Lucha contra la infection hospitalaria. Barcelona: Salvat; 1984. $12 \mathrm{p}$.

Ferraz, MGL et al. Infecção pelo vírus B da hepatite: um risco para o profissional da área de patologia clínica. Revista Brasileira de Patologia Clínica; 1991.27(1):2-5.

Figueiredo R. Opinião dos servidores de um hospital escola a respeito de acidentes com material pérfurocortante na cidade de Campinas-SP. Revista Brasileira de Saúde Ocupacional; 1992. 20.( 76); p.26-33. 
Fitch $\mathrm{K}$ et al. Transmissión accidental del HIV en el ámbito sanitário. Pub Of Seisida; 1993.4(9).

Foucault M. Microfísica do poder. $17^{\mathrm{a}}$ ed. Rio de Janeiro: Graal; 2002. p.39-111.

Freemann J. Prevention of nosocomial infections by location of sinks for handwashing adjacent to bedside [abstract 60]. $3^{\text {rd }}$ Interscience conference on antimicrobial agents and chemotherapy. New Orleans, LA. 1993 October. p17-20.

Garfield J. O trabalho alienado, stress e doença coronariana. In: Nunes ED. Medicina Social: Aspectos históricos e teóricos. São Paulo: Global.1983. p.159175.

Garner JS. The Hospital Infection Control Advision Committee. Guideline for isolation precautions in hospitals. Infect Control and Hospital Epidemiology. 1996. v. 17:54-80.

Garner JS, Simmons BP. Guideline for isolation precautions in hospitals. Infect Control and Hospital Epidemiology; 1983. v.4, p.245-325.

Gerberding JL. Management of occupational exposure to blood - borne viruses. New England Journal of Medicine 1995; 332(7):444-50.

Gibas $\mathrm{A}$ et al. Prevalence and incidence of viral hepatitis in health care workers in the pre-hepatitis B vaccination era. American Journal of Epidemiology. 1992. $136: 603-610$.

Gil AC. Métodos e técnicas de pesquisa social. $5^{a}$ ed. São Paulo:Atlas; 1999. 206p. 
Gilmore DS et al. Category 1,2,3 and 4: a procedure oriented isolation system. Infect Control; 1986; 7:263-7.

Godin $G$ et al. Determinants of nurses' adherence to universal precautions for venipunctures. American Journal of Infection Control; 2000 October. v.28(5):359364.

Gontijo Júnior OM. Avaliação das comissões de controle de Infeç̧ão Hospitalar em Belo Horizonte. Proposta para Incremento da Resolutividade. Belo Horizonte: Fac Med UFMG. 1991 [Tese de doutorado].

Grime PR et al. Pan-themes survey of occupational exposure to HIV and the use of post-exposure prophylaxis in 71 NHS trusts. Journal of Infection 2001 v.42 p.2732.

Gyawali P, et al. Exposure to blood borne viruses and the hepatitis B vaccination status among healthcare workers in inner London. Occup Environ Med. 1998. $55: 570-572$.

Hadler SC. Hepatitis B virus infection and health care workers. Vaccine. 1990. 8:524-8.

Haguette TMF. Metodologia qualitativa na sociologia. Petrópolis(RJ):Vozes. 1995. p.26.

Harris $\mathrm{AD}$ et al. A survey on handwashing practices and opinions of healthcare workers. Journal of Hospital Infection. 2000. 45(4):318-321.

Henderson DK. Postexposure prophylaxis for occupational exposure to hepatitis B, hepatitis c, and human immunodeficiency virus. Surg Clin North America. 1995. $75(6): 1175-87$. 
Henderson DK. Raising the bar: The need for standardizing the use of "standard precautions" as a primary intervention to prevent occupational exposures to bloodborne pathogens. Infection Control and Hospital Epidemiology 2001 $22(2): 70-72$.

Henry $\mathrm{K}$ et al. A comparison of observed and self reported compliance with universal precautions among emergency department personnel at a Minnesota public teaching hospital: implications for assessing infection control programs. Annals of Emergency Medicine. 1992. 21(8):940-6.

Henry $\mathrm{K}$ et al. Compliance with universal precautions and needle handling and disposal practices among emergency department staff at two community hospitals. American Journal of Infection Control 1994; 22(3):129-37.

Hersey JC, Martin LS. Use of infection control guidelines by workers in healthcare facilities to prevent occupational transmission of $\mathrm{HBV}$ and HIV: Results from a national survey. Infect Control and Hospital Epidemiology $1994 ; 15$ (4):243-252.

Hoffman $\mathrm{M}$ et al. Impact of human immunodeficiency virus on medical and surgical residents. Arch Intern Med; 1992 ; 152(9): 1788-96.

Huskins et al. Infection control in countries with limited resources. In: Mayhall. C. G (Ed) - Hospital Epidemiology and Infection Control. Baltimore, Williams I Wilkins. 1996. p.1176-1200.

Jagger $J$ et al. A study of patterns and prevention of blood exposures in OR personnel. AORNJ 1998; 67(5):979-95.

Jornal da SBI. Informativo da sociedade brasileira de infectologia. Acidentes com agulhas merecem atenção cada vez maior .São Paulo. Dezembro 1995. 4(4):1. 
Kaczamarek RG et al. Glove use by health care workers: Results of a tristate investigation. American Journal of Infection Control. 1991 october. 19(5):228232.

Koziol DE e Henderson DK. Nosocomial viral hepatitis in healthcare workers. Hospital Epidemiology and Infection Control. $2^{\mathrm{a}}$ ed. Philadelphia: Glen Mayhall.1999. p.1057-1073.

Kretzer EK, Larson EL. Behavioral interventions to improve infection control practices. American Journal of Infection Control 1998; 26(3):245-253.

Kritsky $\mathrm{AL}$ et al. (orgs.). Tuberculose: do ambulatório à enfermaria. 2. ${ }^{a}$ ed. São Paulo: Atheneu, 1998. p.1-20.

Lacerda RA. Exposição ocupacional ao sangue e a outras substâncias orgânicas de pacientes em unidades de centro cirúrgico de hospitais do Brasil. 2000. [Tese de livre docência - EEUSP]

Lapides M. Emphasize handwashing benefits. Occup Health Sal. 1993. 62(4):72-9.

Larson E, Kretzer K. Compliance with handwashing and barrier precautions. Journal of Hospital Infection 1995; 30 (supppl):88-106.

Laurell AC, Noriega M. Processo de produção e saúde: trabalho e desgaste operário. São Paulo:Hucitec. 1989. p.99-149.

Lee DJ et al. Epidemiology of hepatitis B vaccine acceptance among urban paramedics and emergency medical technicians. American Journal of Infection Control 1997.25(5):421-423. 
Lefèvre $\mathrm{F}$ et al. $\mathbf{O}$ discurso do sujeito coletivo: Uma nova abordagem metodológica em pesquisa qualitativa. Caxias do Sul(RS): Educs; 2000. 138p.

Levine A, Godoy M. Healthcare workers and occupational exposure to AIDS. Nurs Management. 1992. (23(1). 59-60.

Lima DA, Oliveira JC de. A formação de recursos humanos para a CIPA: uma nova abordagem. In: V Congresso da Associação Nacional de Medicina do Trabalho. Brasil: Associação Nacional de Medicina do Trabalho. 1987. p.555-580.

Lima SR et al. Abordagem de DST e AIDS no currículo de medicina da UFPB. Jornada Brasileira de Doenças Sexualmente Transmissíveis 2000. 12(5):87.

Linnemann et al. Effect of educational programs, rigid sharps containers and universal precaution on reported needlestick injuries in healthcare workers. Infect Control and Hospital Epidemiology. 1991. 12(4):214-19.

Lins JFAB de A. Biossegurança: de quem é o compromisso pelo cuidado seguro? Cuiabá;1998. [Dissertação de mestrado - UFSC/UFMT]

Mac Coy $\mathrm{KD}$ et al. Monitoring adherence to standard precautions. Am Journal of Infect Control. 2001. 29(1):24-31.

Map - Monitoring the Aids Pandemic Network. The status and trends of the HIV/AIDS/STD Epidemics in Latin America and Caribbean. 1997. Nov 4-5. Rio de Janeiro, Brazil. Available from: URL:http://www.aids.gov.br/udtv/map-map.htm [1999 set 23].

Marques SR. Infecção hospitalar - medidas preventivas (isolamento e precauções). In: Pediatria Moderna. 2000 v.XXXVI(1/2). Jan-fev p.55:56;58-60;62-63. 
Marquez GSY. Filosofia Moral. Andaluzia:Ceron Impressor. 1991.

Mello JB. Evolução da Cirurgia - Histórico. Iatros 1980; 5(1):10-15.

Mendes EV et al. Distritos sanitários: conceitos-chave in: Distrito sanitário: $\mathbf{O}$ Processo Social de mudança das práticas sanitárias do sistema único de saúde. Rio de Janeiro: Hucitec/Abrasco. 1999. p.159-185.

Meneghin P. Entre o medo da contaminação pelo HIV e as representações simbólicas da AIDS: O espectro do desespero contemporâneo. Revista da Escola de Enfermagem da USP. 1996. 30(3):399-15.

Menzies D et al. Tuberculosis among health care workers. New England Journal of Medicine. 1995 ;332( 2). p.92-98.

Meredith S et al. Are healthcare workers in England and Wales at increased risk of tuberculosis? British Medical Journal. 1996. 313:522-525.

Messmer PR et al. Knowledge, perceptions, and practice of nurses toward HIV+/AIDS patients diagnosed with tuberculosis. The Journal of Continuing Education in Nursing. 1998. 29(3):117-125.

Michalsen A et al. Compliance with universal precautions among physicians. JOEM. $1997 ; 39(2): 130-137$.

Millward S e Thomlinson D. A clinical infection control audit program: evaluation of audit tool used by infection control nurses to monitor standards and assess effective staff training. Journal of Hospital Infection. 1993. 24:219-232. 
Minayo MC. O desafio do conhecimento - pesquisa qualitativa em saúde. $4^{\mathrm{a}}$ ed. São Paulo: Hucitec, 1996. 269p.

Miranda AFB et al. Risco profissional e profilaxia nosocomial de AIDS e hepatite B. Arquivo Catarinense de Medicina; 1993 jan-jul . 22(1/2):55-63.

Moore $\mathrm{S}$ et al. Compliance with universal precautions among pediatric residents. Arch Pediatric and Adolesc Med. 1998;152(6):554-557.

Morgan DR. HIV and needlestich injuries [letter]. Lancet 1990; 335(8700): 1280.

Naing L et al. The prevalence of, and factors related to, compliance with glove utilization among nurses in hospital university of Sans Malaysia. Southeast Asian Journal Tropical Medical Public Health. 2001; 32(3):36-642.

Napoleão AA. Causas de subnotificação de acidentes de trabalho: visão dos trabalhadores de um hospital do interior paulista. Ribeirão Preto(SP). 1999. [Dissertação de mestrado - EEUSP].

Olievenstein O. O não dito das emoções. Rio de Janeiro:Zahar.1989. p.127-138.

Oliveira JR. Saúde, tuberculose e condições de trabalho: Representações dos trabalhadores de Enfermagem. Rio de Janeiro; 1996. [Dissertação de mestrado EEAN-UFRJ].

Oliveira TC. Controle de infecção hospitalar como indicador da qualidade dos hospitais do município de Campinas e região. Campinas(SP); 1997. [Tese de Doutorado - UNICAMP]. 
O'Rourk $\mathrm{M}$ et al. Universal precautions - do Irish anaesthesists comply? Irish Journal of Medical Science. 2000. 169(3):211-214.

Pagliari AV, Melo NSFO. Prevalência da vacinação contra a hepatite $B$ entre estudantes de odontologia da Universidade Federal do Paraná. Revista da Faculdade de Odontolologia de Bauru; 1997 ; 5(1/2):79-86.

Pannuti CS, Grinbaum RS. Global aspects of infection control: part I. An overview of nosocomial infection control in Brazil. Infection Control and Hospital Epidemiology. 1995. 170-174.

Pasternak J et al. Imunoprofilaxia da hepatite B: vacinação em um hospital geral de São Paulo com adequação da metodologia utilizada a nossa realidade sócioeconômica. Revista do Hospital das Clínicas da Faculdade de Medicina da Universidade de São Paulo;1991; 46(1):38-40.

Paulilo MAS. AIDS: Os sentidos do risco. São Paulo: Veras; 1999 (série temas;3)

Penteado EVFB. Tuberculose no ambiente hospitalar: Uma questão da saúde do trabalhador. Rio de Janeiro; 1999. [Dissertação de Mestrado - ENSP]

Pereira MS, Moriya TM. Infeç̧ão hospitalar. Estrutura básica e controle. $2^{\mathrm{a}} \mathrm{ed}$. Goiânia: A/B.1995. 193p.

Pittet D et al. Compliance with handwashing in a teaching hospital. Annals of Internal Medicine. 1999 January. 130(2):126-130.

Pittet D. Improving adherence to hand hygiene practice: A multidisciplinary approach. Emerging Infectious Diseases;2001.7(2):234-240. 
Ponce de Leon SR. Frausto SR. Organizing for infection control with limited resources. In: Wenzel RP(Ed). Prevention and control of nosocomial infections. Baltimore. Williams I Wilkins. 1997. p.85-94.

Prade SS et al. Avaliação da qualidade das ações de controle de infecção hospitalar em hospitais terciários. Revista Controle de Infecção Hospitalar. 1995. 2(2):2640 .

Raad I et al. Annual tuberculin skin testing of employees at a university hospital: A Cost-Benefit Analysis. Infection Control and Hospital Epidemiology; 1989. $10(10): 465-469$.

Rabaud $\mathrm{C}$ et al. Occupational exposure to blood: search for a relation between personality and behavior. Infection Control and Hospital Epidemiology; 2000. $21(9): 564-574$.

Ramsey PW, Glenn LL. Nurses' body fluid exposure reporting HIV testing, and hepatitis $\mathrm{B}$ vaccination rates. Before and after implementing universal precautions regulations.AAOHNJ.1996.44(3):129-137.

Rapparini C. Acidentes ocupacionais por material biológico. Saúde em Foco. Ano VII, n 17. Secretaria de Saúde. Rio de Janeiro; 1998.

Revista Proteção. Uma nova regulamentação. Revista Proteção. No 124. Abril de 2002. Ano XV.p.53.

Rezende MR. Prevalência de Infecção tuberculosa em profissionais do Hospital das Clínicas da Universidade Estadual de Campinas. 1996. [Dissertação de mestrado - UNICAMP].

Ribeiro HP. O hospital: história e crise. São Paulo: Cortez; 1993. 135p. 
Riscado JLS. Aids, prevenção e prontidão profissional: Um estudo sobre comportamento sexual, conhecimento, representações e prontidão profissional com estudantes da área de saúde da Universidade Federal de Alagoas. São Paulo;1998 [Dissertação de mestrado - Pontifícia Universidade Católica de São Paulo].

Rodrigues MP. Representações sociais dos cirurgiões dentistas sobre a utilização das medidas de biossegurança na cidade de Natal; 2000. [Dissertação de mestrado - UFRN].

Rodriguez BE et al. Underreporting of percutaneous exposure accidents in a teaching hospital in Spain. United States. Clin Perform Qual Health Care; 1999 ; 7(2):8891.

Rosen G. O hospital - sociologia histórica de uma Instituição comunitária. In Da polícia médica à medicina social: Ensaios sobre a história da assistência médica. Rio de Janeiro: Graal, 1980. p.335-370.

Rourke C, Read RC. Poor hospital infection control practice in venipuncture and use of tourniquets. Journal of Hospital Infection. 2001. 49:59-61.

Rowe PM, Giuffre M. Evaluating needlestick injuries in nursing personnel. AAOHNJ. 1991. 39(11):503-7.

Rozembaum R. Estudo da prevalência e dos fatores de risco para infecção pelo vírus da hepatite $\mathrm{B}$ e hepatite $\mathrm{C}$ em profissionais da área da saúde. Rio de Janeiro. 1998. [Tese de doutorado - UFRJ]

Saghafi $\mathrm{L}$ et al. Exposure to blood during various procedures: Results of two surveys before and after the implementation of universal precautions. American Journal of Infect Control 1992. 20(2) p.53-57. 
São Paulo. Resolução n. ${ }^{\circ}$, de 21/03/00. Diário Oficial do Estado. Poder Executivo. São Paulo,13/04/00. Seção I, p.62-63.

SAS INSTITUTE INC. SAS/STAT User's Guide. Release 6.03. Cary, NC: SAS Institute Inc, 1988, 1028p.

Schneider LOD. La tuberculosis profesional en los trabajadores de la salud. Salud Ocupacional. 1996. 14(64):4-13.

Schramm FR. Bioética e biossegurança. In: Costa SIF, Oselka G, Garrafa V (coord). Iniciação à bioética. Brasília(DF). CFM.1998. p.217-30.

Sepkowitz KA et al. Tuberculosis and the health care worker: A historical perspective. In: Annals of Internal Medicine;1994. 120. nº 1. p.71-79.

Sepkowitz KA et al. Benefit of two-step PPD testing of new employees at a New York City hospital. American Journal of Infection Control. 1997. 25(3):283-286.

Sharir $\mathrm{R}$ et al. High-level handwashing compliance in a community teaching hospital: a challenge that can be met!. Journal of Hospital Infection. 2001;49:5558.

Shiao JS et al. Prevalence of nonreporting behavior of sharps injuries in Taiwanese health care workers, United States. American Journal of Infect Control; 1999; $27(3): 254-7$.

Silva AMC et al. Precauções e Isolamento. In: Fernandes AT e cols. Infecção hospitalar e suas interfaces na área da saúde. São Paulo: Atheneu, 2000. v.2. 1008-1019. 
Silva A. Trabalhador de enfermagem na unidade centro de material e os acidentes de trabalho. São Paulo;1996.[Tese de Doutorado - USP].

Silva GA. Por detrás das luvas e máscaras: Representações das enfermeiras sobre a Aids. Rio de Janeiro. 1997. [ Dissertação de mestrado - EEAN.UFRJ)

Siqueira et al. O desgaste físico e mental em auxiliares de enfermagem: Uma análise sob o enfoque gerencial. Revista Latino Americana de Enfermagem. 1995. $3(1): 45-57$.

Siquéria EJD. Saúde ocupacional e medidas de biossegurança. In: Martins, M. A. E Cols. Manual de Infecção Hospitalar. Epidemiologia, Prevenção e Controle. 2. ${ }^{a}$ ed. Rio de Janeiro: Medsi. 2001. p.643-673.

Souza ACS. Risco biológico e biossegurança no cotidiano de enfermeiros e auxiliares de enfermagem. Ribeirão Preto(SP). 2001 [Tese de doutorado - EEUSP].

Souza M. Conhecimento e aplicação das precauções universais pelos componentes da equipe de enfermagem de um hospital governamental. São Paulo; 1994. [Dissertação de Mestrado - UNIFESP]

Souza M. Acidentes ocupacionais e situações de risco para equipe de enfermagem: Um estudo em cinco hospitais do município de São Paulo. São Paulo.1999. [Tese de doutorado - UNIFESP]

Spink MJP, Medrado B. Práticas discursivas e produção de sentidos no cotidiano: aproximações teóricas e metodológicas. In: Spink MJP, Organizador. Produção de sentidos no cotidiano: Uma abordagem teórico-metodológica para análise das práticas discursivas. $2^{a}$.ed.São Paulo: Cortez;2000. P.41-61 . 
Steagall - Gomes, DL. Estudo dos riscos à saúde das pessoas que trabalham na enfermagem hospitalar. Revista Paulista de Hospitais. 1986. 34(4/5/6):85-93.

Stroffolini T et al.Hepatitis B Vaccination Coverage Among Healthcare workers in Italy. Concise Communications. Infection Control and Hospital Epidemiology; 1998. 19(10):789-791.

Suazo SVV. Contribuição ao estudo sobre acidentes de trabalho que acontecem aos trabalhadores de enfermagem em hospitais chilenos. 1999 [Tese de Doutorado - EERP-USP].

Takeda E. Tuberculose: Um estudo de sua situação entre pacientes internados e equipe de enfermagem de um Hospital Escola de Ribeirão Preto, São Paulo. 1996.[Dissertação de mestrado - EERP-USP]

Tandberg D et al. Under-reporting of contaminated needlestick injuries in emergency health care workers. Annals of Emergencial Medicine. 1991.20(66):66-70.

Teixeira P, Valle S. Biossegurança - Uma abordagem multidisciplinar. Rio de Janeiro: Fiocruz; 1998. 362p.

Tholinson D et al. A clinical infection control audit program: evaluation of on audit tool used by infection control nurses to monitor standards and assess effective staff training. Journal of Hospital Infection. 1993. 24:219-232.

Thompson SC, Norris M. Hepatitis B Vaccination of personnel employed in victorian hospitals: Are those at risk adequately protected? Infection Control and Hospital Epidemiology. 1999; 20(1):51-54.

Tura LFR. Os jovens e a prevenção da AIDS no Rio de Janciro. Rio de Janeiro. 1997 [Tese de doutorado - Faculdade de Medicina UFRJ]. 
Vianna LG. Semmelweiss e a Febre Puerperal. Jornal Brasileiro de Ginecologia $1983 ; 93(2): 75-76$.

Wagennar WA. Risk evaluation and the causes of accidents. In: Borcherding K,Larichev, OI, Messic KDM. (eds) Contemporary issues in decision making. Amsterdam, North Holland. 1990. p.245-60 [resumo].

Weltman A et al. Disposal related Sharp injuries at a New York City. Teaching Hospital. Infection Control and Hospital Epidemiology 1995; 16(3):168-74.

Whipple AO. História da Cirurgia. In: Davis L. Clínica Cirúrgica. $7^{\mathrm{a}}$ ed. Rio de Janeiro: Guanabara Koogan, 1961. p. 1-121.

White $\mathrm{AH}$ et al. Respiratory isolation in a teaching hospital with low-to-moderate rate of tuberculosis: Compliance with centers for disease control and prevention guidelines for identifying patients who may have active tuberculosis. American Journal of Infection Control. 1997.25 (6.) p.467-470.

Williams $\mathrm{CO}$ et. al. Variables influencing worker compliance with universal precautions in the emergency department. American Journal of Infection Control. $1994 ; 22(3): 138-148$.

Young F. W. Encyclopedia of Statistical Sciences. Jonh Wiley \& Sons, Inc. 1985. V.5. 
ANEXOS 


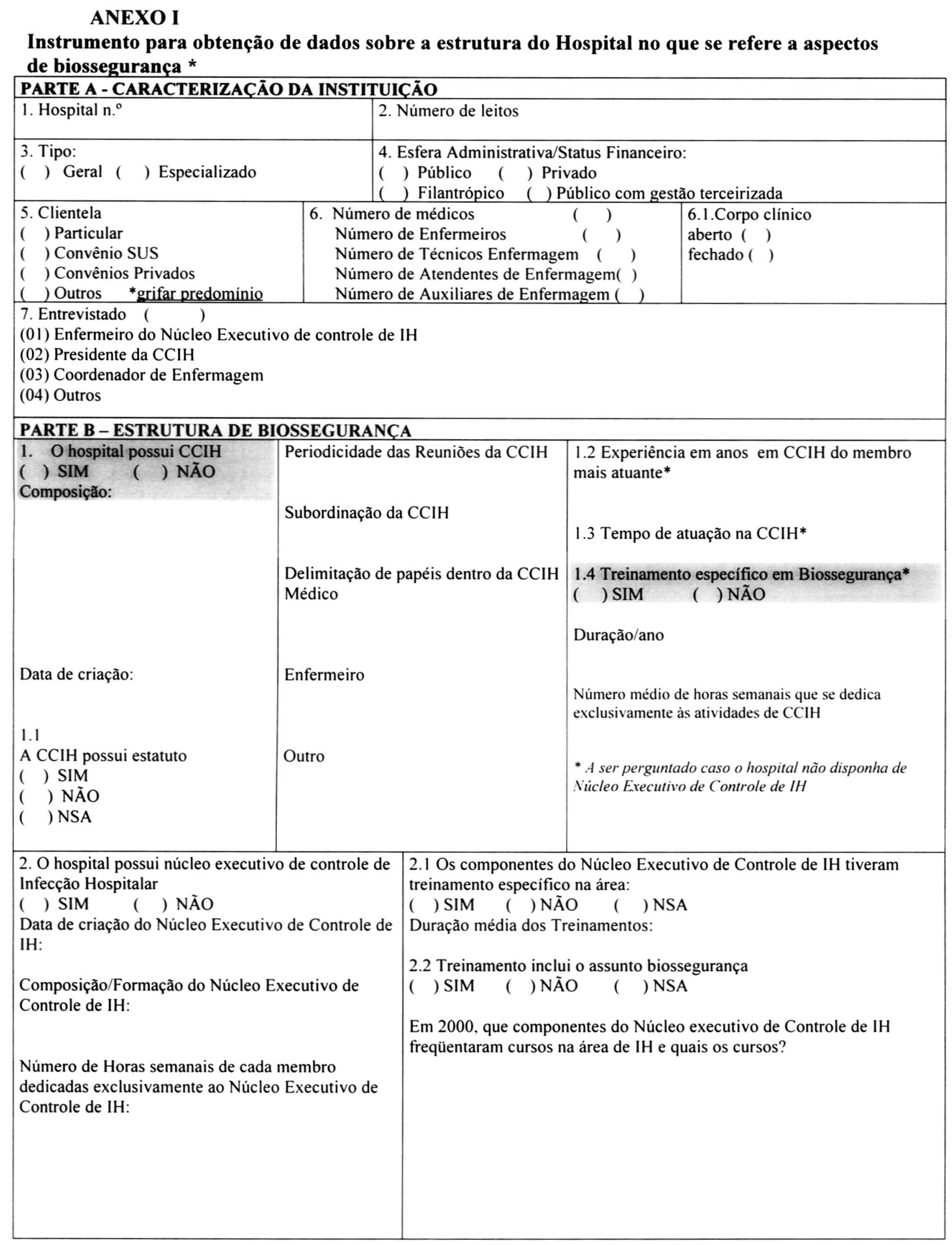


Atividades desenvolvidas pelos componentes do Núcleo Executivo de Controle de IH. Descreva:
Experiência em Controle de Infecção Hospitalar em anos de cada um dos membros do Núcleo Executivo de Controle de IH
3. O hospital possui serviço médico ocupacional ( ) $\operatorname{SIM}($, ) NÃO

3.1 O serviço médico-ocupacional tem estatuto? ( ) SIM ( ) NÃO ( ) NSA

Data de Criação do serviço médico ocupacional

Composição do serviço médico ocupacional

Número de Horas semanais de cada membro dedicadas exclusivamente ao serviço médico ocupacional

Atividades desenvolvidas pelo serviço médico ocupacional. Descreva:
3.2 Treinamento específico na área de biossegurança dos componentes do serviço médico ocupacional

( ) SIM ( ) NÃO

Duração média dos Treinamentos:

Em 2000, que componentes do serviço médico-ocupacional freqüentaram cursos relacionados à área de biossegurança e quais os cursos?

\section{O Hospital possui CIPA: \\ ( ) SIM ( ) $\mathrm{NÃO}$ \\ 4.1 A CIPA tem estatuto? \\ ( ) SIM ( ) NÃO ( ) NSA \\ 4.2 Algum membro da CIPA já foi treinado (freqüentou curso) em biossegurança \\ ( ) SIM ) $\mathrm{NÃO}$ ( ) NSA \\ Duração/Ano}

5. O uso das precauções padrão (também denominadas precauções básicas)

É norma neste hospital?

$$
\text { ( ) SIM ( ) NÃO }
$$

5.1 A norma acerca das precauções padrão, adaptada para o hospital, está escrita?

\section{( ) SIM ( ) NÃO ( ) NÃO SE APLICA}

5.2 Há um sistema de monitoramento do emprego das precauções padrões na prática?

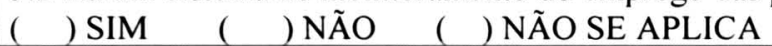

5.3 Há um sistema de Treinamento do pessoal envolvido no N. $^{\circ}$ de treinamentos realizados em 2000: atendimento em relação a essa norma?

( ) SIM ( ) NÃO ( ) NÃO SE APLICA

$\mathrm{N} .^{\circ}$ de treinamentos realizados nos últimos 06 meses:

Percentual aproximado de profissionais treinados por categoria: 


\section{Os procedimentos abaixo elencados}

Lavagem das mãos antes e após contato com o paciente

Lavagem das mãos após retirada das luvas

Lavagem das mãos após contato com sangue, feridas corpóreas, secreções,

excreções

Uso de luvas quando existir possibilidade de contato com sangue, feridas corpóreas, secreções e excreções, membranas mucosas, pele não íntegra

Uso de Máscara para procedimentos que envolvam a possibilidade de respingo

Uso de protetor de olhos para procedimentos que envolvam a possibilidade de respingo

Uso de protetor de face para procedimentos que envolvam a possibilidade de respingo

Uso de avental para procedimentos que envolvam a possibilidade de respingo

Uso de sacos impermeáveis para o transporte de roupas sujas de sangue, líquidos corporais, secreções e excreções

Não desconexão de agulhas das seringas utilizadas

Não re-encape de agulhas utilizadas

Descarte do material pérfuro-cortante em recipientes resistentes (norma IPTN NEA 55)

Preenchimento do recipiente coletor até a linha tracejada

Descarte imediato dos materiais pérfuro-cortantes em recipientes localizado no

mesmo quarto ou aposento que foi realizado o procedimento

6. O Uso das precauções baseadas na transmissão é norma neste hospital?

( ) SIM ( ) NÃO

6.1 As normas acerca das precauções baseadas na transmissão está escrita e adaptada para o hospital?

( ) SIM ( ) NÃO ( ) NÃO SE APLICA

6.2 Há um sistema de monitoramento do emprego das precauções baseadas na transmissão na prática?

( ) SIM ( ) NÃO ( ) NÃO SE APLICA

6.3 Há um sistema de Treinamento do pessoal envolvido, no atendimento em relação às precauções baseadas na transmissão?

( ) SIM ( ) NÃO
Fazem parte das recomendações internas do

Hospital e de rotina

SIM $\mid$ NÃO

Na sua percepção, são seguidos de rotina pelos profissionais de saúde do hospital

\section{SIM $\quad$ NÃO}

\begin{tabular}{l|l|l} 
SIM & NÃO
\end{tabular}




\begin{tabular}{|c|c|c|c|c|c|}
\hline \multirow[t]{2}{*}{ Os procedimentos abaixo elencados } & \multicolumn{2}{|c|}{$\begin{array}{c}\text { Fazem parte das } \\
\text { recomendações } \\
\text { internas do } \\
\text { Hospital e de } \\
\text { rotina }\end{array}$} & \multicolumn{2}{|c|}{\begin{tabular}{|l} 
Na sua \\
percepção são \\
seguidos de \\
rotina pelos \\
profissionais de \\
saúde do \\
hospital \\
\end{tabular}} & \multirow[t]{2}{*}{$\begin{array}{c}\text { Doenças ou condições que se aplicam } \\
\text { os procedimentos de contato neste } \\
\text { hospital }\end{array}$} \\
\hline & SIM & NÃO & SIM & NÃO & \\
\hline
\end{tabular}

\section{PRECAUCCÕES DE CONTATO}

Colocar o paciente em quarto privativo ou comum para pacientes acometidos com a mesma doença ou microorganismo

Usar luvas de procedimento para qualquer contato com o paciente

Retirar as luvas antes de sair do quarto

Usar avental se houver possibilidade de contato das roupas do profissional com área ou material infectante

Retirar o avental antes de sair do quarto

Usar artigos e equipamentos (estetoscópio,

termômetros, etc...) exclusivos para o paciente

\section{PRECAUÇÕES RESPIRATÓRIAS PARA AEROSSÓIS}

Colocar o paciente em quarto privativo

Manter a porta do quarto fechada

Manter a janela do quarto aberta

Facilitar a iluminação pela luz solar

Usar máscara N95 (para o profissional)

Colocar máscara cirúrgica no paciente em deslocamento

\begin{tabular}{|l|l|l|l|l|}
\hline & & & & \\
\hline & & & & \\
\hline & & & & \\
\hline & & & & \\
\hline & & & & \\
\hline
\end{tabular}

\section{PRECAUÇÕES COM GOTÍCULAS}

Colocar o paciente em quarto privativo ou em quarto comum para paciente acometidos com mesmo microorganismo

Usar máscaras cirúrgicas para o contato com o paciente

Colocar máscara cirúrgica no paciente em deslocamento
7. Existe no hospital mapa de riscos biológicos ?
( ) SIM ( ) NÃO
8. O hospital dispõe de um sistema de registro de acidentes de profissionais com material pérfuro-cortante? ( ) SIM ( ) NÃO
Na hipótese afirmativa quem registra?
( ) $\mathrm{CCIH}$
( ) $\mathrm{SMO}$
( ) Núcleo Executivo de controle de infecção hospitalar
( ) Outro
Os registros são realizados nos turnos?
() $\mathrm{M}(\mathrm{l}) \mathrm{V} \quad(\mathrm{l}) \mathrm{N}$

9. O hospital dispõe de um sistema de registro de casos de profissionais do hospital doentes com nexo ocupacional?

( ) SIM ( ) NÃO

Caso positivo, qual o $\mathrm{n}^{\circ}$ de doentes registrados no ano 2000 .
Doenças e/ou condições que se aplicam os procedimentos de precauções respiratórias neste hospital chas e/ou condições que se aplicam os procedimentos de precauções com gotículas neste hospital 


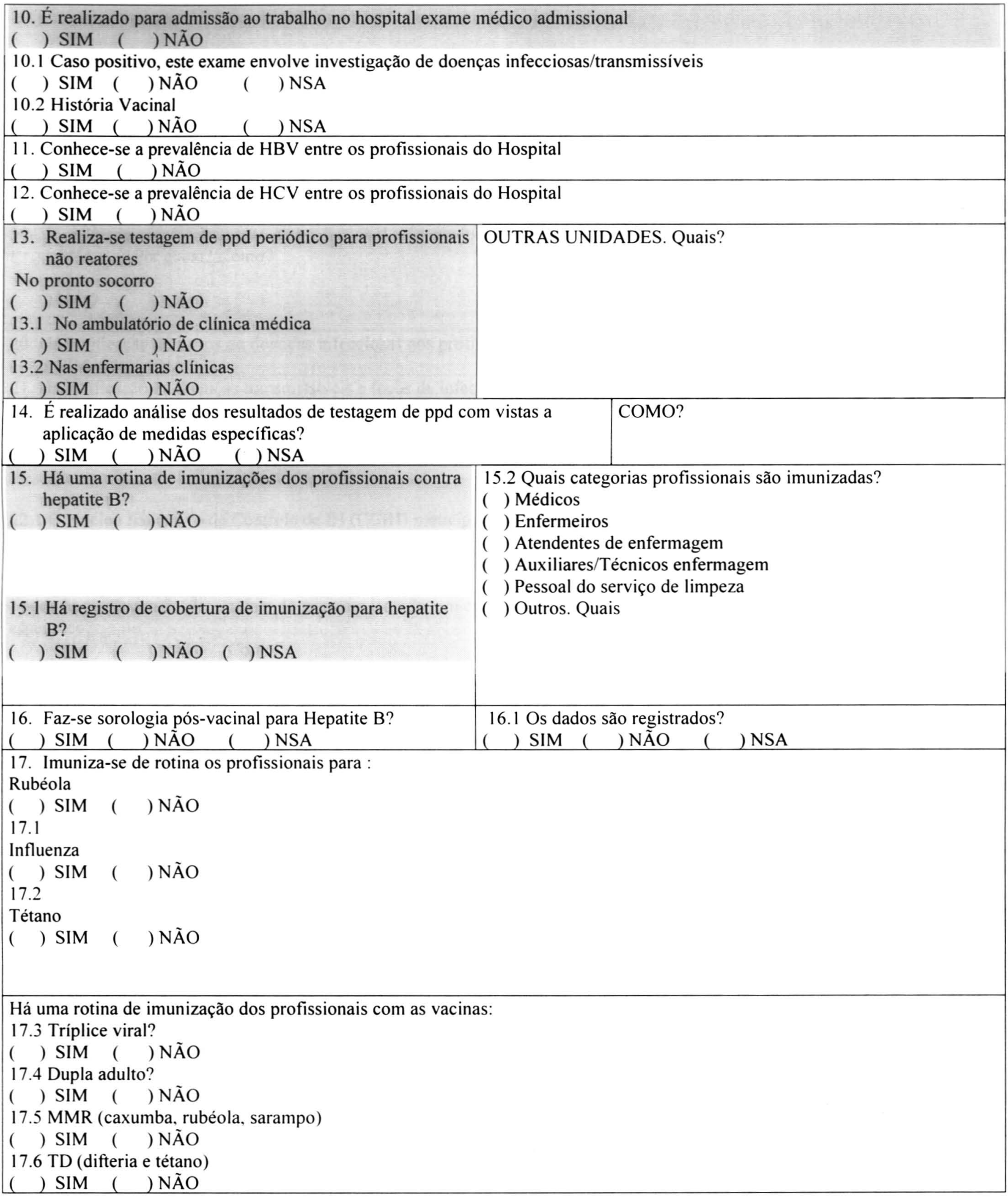




\section{Existe no hospital normas de atendimento para os casos de acidentes de profissionais do hospital com materiais pérfuro- cortantes? \\ ( agulhas, bisturis) \\ ( ) SIM}

19. É realizado acompanhamento de profissional acidentado com material pérfuro-cortante?

( ) SIM Por quem?/Como?

( ) NÃO

20. Há notificação de surtos de doenças infecciosas nos profissionais atuantes no hospital?

( ) SIM ( ) NÃO

21. Há notificação de doenças transmissíveis e focos de infecção nos profissionais atuantes no hospital?

( ) SIM ( ) NÃO

22. O Hospital dispõe de acomodaç̃̃es para isolamentos de pacientes?

( ) $\operatorname{SIM}($ ) NÃO

22.1 O Núcleo Executivo de Controle de IH (CCIH) participa da indicação dos isolamentos?

( ) SIM ( ) NÃO ( ) NSA

22.2 Há um sistema de sinalização para isolamentos?

( ) SIM ( ) NÃO

Todos os profissionais que cuidam do paciente isolado tem conhecimento do conjunto de precauções necessárias ao caso especifico?

( ) SIM ( ) NÃO Como?

22.3 O Núcleo Executivo de controle de $\mathrm{IH}(\mathrm{CCIH})$ supervisiona o uso e as práticas nos isolamentos? ( ) SIM ( ) NÃO ( ) NSA

23. Há, no hospital medidas implementadas para a redução da disseminação intra hospitalar de tuberculose e proteção do profissional de saúde.

( ) SIM-Quais?(por ordem de prioridade)

( ) NÃO

\section{O paciente suspeito de TB é isolado?}

( ) SIM

( ) NÃO

25. Qual é a definição, no seu hospital, de paciente suspeito de tuberculose?

26. Qual é o tempo que, em geral, o hospital obtém o resultado de uma baciloscopia de paciente suspeito de TB? Laboratório que realiza o exame:

27. Neste hospital o uso da máscara N95 pelo profissional de saúde é compulsório, para o trato com os pacientes suspeitos de tuberculose?

( ) SIM ( ) NÃO

28. O uso de luvas para a realização de punções venosas/arteriais é compulsório neste hospital?

) $\operatorname{SIM}()$ NÃO

29. No que se refere a treinamentos específicos

Os profissionais de saúde vinculados a este hospital são sistematicamente treinados para a realização de punção venosa/arterial com o uso de luvas

( ) SIM ( ) NÃO

Quais categorias profissionais foram/são treinadas?

( ) Médicos

( ) Enfermeiros

( ) Aux./ Téc.

Enfermagem

( ) Outros. Quais?
Percentual de profissionais treinados por categoria:

( ) Médicos

) Enfermeiros

) Téc. Enf./Aux. Enfermagem )Outros 


\begin{tabular}{|c|c|c|}
\hline $\begin{array}{l}\text { 29.1 Descarte imediato dos materiais pérfuro-cortantes em } \\
\text { recipientes rígidos, localizados no mesmo quarto ou } \\
\text { aposento onde foi realizado o procedimento } \\
\begin{array}{lll}\text { ) SIM } & \text { ( ) N } \tilde{O} O\end{array}\end{array}$ & $\begin{array}{l}\text { ( ) Médicos } \\
\text { ( ) Enfermeiros } \\
\text { ( ) Aux. / Téc. } \\
\text { Enfermagem } \\
\text { ( ) Outros. Quais? }\end{array}$ & 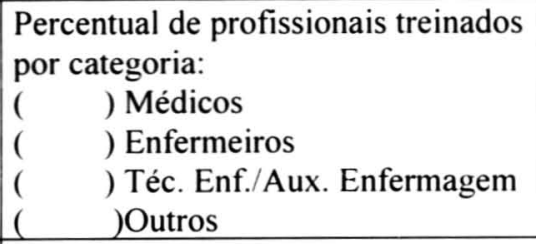 \\
\hline 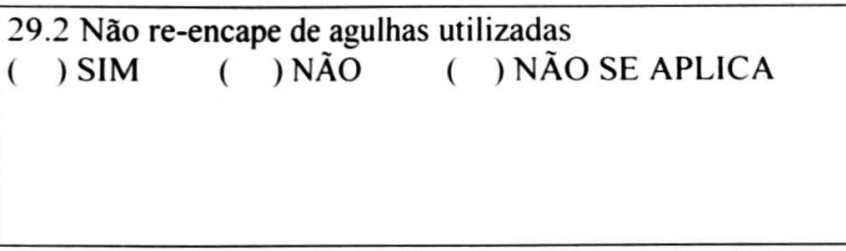 & $\begin{array}{l}\text { ( ) Médicos } \\
\text { ( ) Enfermeiros } \\
\text { ( ) Aux. / Téc. } \\
\text { Enfermagem } \\
\text { ( ) Outros. Quais? }\end{array}$ & 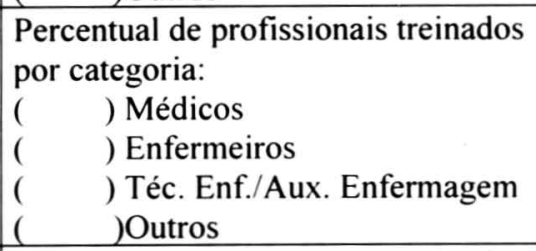 \\
\hline $\begin{array}{l}29.3 \text { Não desconexão de agulhas de seringas utilizadas? } \\
\begin{array}{lll}\text { ( ) SIM } \quad \text { ( ) NÂ }\end{array}\end{array}$ & $\begin{array}{l}\text { ( ) Médicos } \\
\text { ( ) Enfermeiros } \\
\text { ( ) Aux./Téc. } \\
\text { Enfermagem } \\
\text { ( ) Outros. Quais? }\end{array}$ & $\begin{array}{l}\text { Percentual de profissionais treinados } \\
\text { por categoria: } \\
(\quad) \text { Médicos } \\
\left(\begin{array}{l}\text { ( Enfermeiros } \\
( \\
(\end{array}\right) \text { Téc. Enf./Aux. Enfermagem } \\
\text { ( ) Outros }\end{array}$ \\
\hline $\begin{array}{l}29.4 \text { Não preenchimento dos recipientes coletores além da } \\
\text { linha tracejada? } \\
\begin{array}{lll}\text { ( ) SIM } & \text { ( ) NÃO } & (\text { ) NÃO SE APLICA }\end{array}\end{array}$ & $\begin{array}{l}\text { ( ) Médicos } \\
\text { ( ) Enfermeiros } \\
\text { ( ) Aux./ Téc. } \\
\text { Enfermagem } \\
\text { ( ) Outros. Quais? }\end{array}$ & 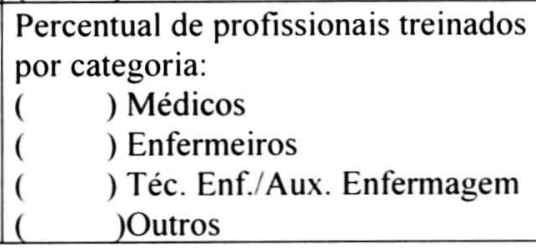 \\
\hline \multicolumn{3}{|l|}{ Quando foi realizado o último treinamento? } \\
\hline \multicolumn{3}{|l|}{ Quantos treinamentos foram realizados no ano $2000 ?$} \\
\hline $\begin{array}{l}29.5 \text { Há treinamento admissional específico para realização } \\
\text { dos procedimentos punção venosa/arterial com o uso de } \\
\text { luvas? } \\
\left.\begin{array}{ll}(\quad) \text { SIM } & (\end{array}\right) \text { NÃO }\end{array}$ & \multicolumn{2}{|c|}{$\begin{array}{l}\text { Caso positivo, quais categorias profissionais são treinadas: } \\
\text { ( ) Médicos } \\
\text { ( ) Enfermeiros } \\
\text { ( ) Auxiliar/Téc. Enfermagem } \\
\text { ( ) Outros. Quais? }\end{array}$} \\
\hline $\begin{array}{l}\text { 29.6 Descarte imediato de materiais pérfuro-cortantes em } \\
\text { recipientes rígidos, localizados no mesmo quarto ou } \\
\text { aposento onde foi realizado o procedimento } \\
\begin{array}{llll} & \text { ) SIM } & \text { ( ) NÃO }\end{array}\end{array}$ & \multicolumn{2}{|c|}{$\begin{array}{l}\text { Caso positivo, quais categorias profissionais são treinadas: } \\
\text { ( ) Médicos } \\
\text { ( ) Enfermeiros } \\
\text { ( ) Auxiliar/Téc. Enfermagem } \\
\text { ( ) Outros. Quais? }\end{array}$} \\
\hline $\begin{array}{l}29.7 \text { Não re-encape de agulhas utilizadas? } \\
\begin{array}{lll}\text { ) }) \text { SIM } & \text { ( ) NÃO }\end{array}\end{array}$ & \multicolumn{2}{|c|}{$\begin{array}{l}\text { Caso positivo, quais categorias profissionais são treinadas: } \\
\text { ( ) Médicos } \\
\text { ( ) Enfermeiros } \\
\text { ( ) Auxiliar/Téc. Enfermagem } \\
\text { ( ) Outros. Quais? }\end{array}$} \\
\hline $\begin{array}{l}29.8 \text { Não desconexão de agulhas de seringas utilizadas? } \\
\begin{array}{lll}\text { ( ) SIM } & \text { ( ) ÃO }\end{array}\end{array}$ & \multicolumn{2}{|c|}{$\begin{array}{l}\text { Caso positivo, quais categorias profissionais são treinadas: } \\
\text { ( ) Médicos } \\
\text { ( ) Enfermeiros } \\
\text { ( ) Auxiliar/Téc. Enfermagem } \\
\text { ( ) Outros. Quais? }\end{array}$} \\
\hline \multicolumn{3}{|c|}{$\begin{array}{l}\text { 30. Os profissionais de saúde vinculados a este hospital são sistematicamente treinados para a triagem precoce de pacientes com } \\
\text { suspeita de tuberculose? } \\
\begin{array}{ll}\text { ( ) SIM ( ) NÃO }\end{array}\end{array}$} \\
\hline \multicolumn{3}{|c|}{$\begin{array}{l}\text { 31. Há, no hospital, estratégias específicas de conscientização profissional para a questão dos riscos ocupacionais para agentes } \\
\text { biológicos? } \\
\begin{array}{ll}\text { ( ) SIM } & (\quad \text { ) NÃO } \\
\text { Qual? }\end{array}\end{array}$} \\
\hline
\end{tabular}


33. Há, no hospital. integração por relatórios entre a CIPA. Medicina do trabalho e Núcleo executivo de Controle de IH (ou $\mathrm{C}(\mathrm{IH})$ ?

(1) SIM () NÀO () NSA

34. Há. no hospital, integração através de reuniões entre a CIPA. Medicina do trabalho e Núcleo Executivo de Controle de IH (ou CCIH)?

() SIM () NÃO ( ) NSA

35. São realizadas auditorias internas para avaliar o cumprimento das medidas de biossegurança?

( ) SIM ( ) NĀO

35.1 Essas auditorias são registradas?

( ) SIM ( ) NÃO ( ) NSA

35.2 Os dados são divulgados?

( ) SIM ( ) NÃO ( ) NSA

36. A partir dos resultados das auditorias internas são implementadas ações corretivas objetivando a melhoria da qualidade dos serviços, no que se refere ao emprego das medidas de biossegurança?

() SIM () NÀO ( ) NSA

37. O Núcleo Executivo de Controle de $\mathrm{IH}($ ou $\mathrm{CCIH})$ é consultado para a indicação de compra de equipamentos de proteção individual?

( ) SIM ( ) NÀO

37. I Na maioria das vezes é atendido?

( ) SIM ( ) NÄO $($ ) NSA

38. O Núcleo Executivo de Controle de IH (ou CCIH) é consultado nos assuntos referentes à estrutura física do hospital? (construções, reformas, adaptações)

( ) SIM ( ) NÄO

38. $1 \mathrm{Na}$ maioria das vezes é atendido?

( ) SIM () NÄO ( ) NSA

39. A quantidade de equipamentos de proteção individual aos profissionais é considerada como suficiente pelo Núcleo Executivo de Controle de IH (ou CCIH)?

( ) SIM ( ) NĀO ( ) NSA

39.1 Na sua percepção, a CIPA considera a quantidade de equipamentos de proteção individual aos profissionais como suficiente. no hospital?

1, SIM $($ ) NÀO, NSA

39.2 Na sua percepçào os funcionários consideram a quantidade de equipamentos de proteção individual como suficiente. no hospital?

$(1)$ SIM NÃO

40. O uso do EPl é supervisionado pelo Núcleo Executivo de Controle de IH (ou CCIH) no hospital?

( ) SIM ( ) NÀO ( ) NSA

Caso positivo. quem supervisiona o uso?

O que ocorre com o funcionário que não esteja usando?

41. O Núcleo Executivo de Controle de $\mathrm{IH}$ (ou $\mathrm{CCIH}$ ) tem apoio administrativo no que se refere a implementação das medidas de biossegurança?

( ) SIM ( ) NÀO ( ) NSA

41. I Na sua percepçăo. o serviço médico-ocupacional tem apoio administrativo no que se refere a ações relativas a medidas de biossegurança.
( ) SIM
) $\mathrm{NÄO}$
( ) NSA

42. A administraçào do hospital cobra do Núcleo Executivo de Controle de IH (ou CCIH) ações especificas no que se refere à implementação de medidas de biossegurança?

() SIM ( ) NÃO ( ) NSA 
43. Os profissionais de saúde do hospital cobram do Núcleo Executivo de Controle de IH (ou CCIH) ações especificas, no que se refere à biossegurança?

( ) SIM ( ) NÃ̃O ( ) NSA

Caso positivo, que açðes são cobradas:

Caso positivo. que categorias profissionais mais reivindicam ações:

44. Na sua percepção. a administração do hospital cobra do serviço médico-ocupacional ações especificas relacionadas a medidas de biossegurança?

( ) SIM ( ) NÃO ( ) NSA

45. Na sua percepçào. os profissionais de saúde do hospital. cobram do serviço médico-ocupacional ações especificas relacionadas a medidas de biossegurança

(1) SIM ( NÄO ( ) NSA

46. Na sua percepção. os profissionais de saúde do hospital, cobram da CIPA ações especificas relacionadas a medidas de biossegurança

( ) SIM ( ) NÃO ( ) NSA

47. O Hospital tem programa de cooperação ou recebe assessoria de algum órgão de referência no que se refere a Biossegurança?

( ) SIM ( ) NÃO Qual?

48. O hospital jả foi visitado pela vigilância sanitária na busca de informaçòes acerca de aspectos do cumprimento das normas de biossegurança?

( ) SIM ( ) NÃO ( ) Não saberia dizer Quando?

49. Do ponto de vista da proteção do trabalhador no que se refere aos riscos biológicos a que pode estar submetido. há alguma ação especifica. nào perguntada. mas considerada relevante que é aplicada pelo hospital?

* Os itens sombreados foram os analisados para a avaliaçào dos hospitais 


\section{ANEXO II}

\begin{tabular}{|c|c|c|c|c|c|}
\hline \multicolumn{6}{|c|}{ INSTRUMENTO II - Ficha de Observação de Procedimento } \\
\hline \multicolumn{6}{|c|}{ ANÁLISE DO PROCESSO } \\
\hline \multicolumn{6}{|c|}{ Procedimento: Acesso venoso / arterial } \\
\hline \multicolumn{2}{|l|}{ 1. Hospital } & \multicolumn{4}{|c|}{ 2. Unidade/Setor } \\
\hline \multicolumn{2}{|c|}{ 3. Procedimento } & 4. Data & \multicolumn{3}{|l|}{ 5. Hora } \\
\hline \multicolumn{2}{|c|}{$\begin{array}{l}\text { 6. Categoria do profissional } \\
\text { Observado }\end{array}$} & \multicolumn{4}{|c|}{$\begin{array}{l}\text { 7. Sexo } \\
\text { ( ) Masculino ( ) Feminino }\end{array}$} \\
\hline \multicolumn{2}{|c|}{$\begin{array}{l}\text { 8. Número de anos de formado do } \\
\text { profissional }\end{array}$} & \multicolumn{4}{|c|}{ 9. Tempo de serviço na área: } \\
\hline \multicolumn{2}{|c|}{ 10. Tempo de serviço na Instituição } & \multicolumn{4}{|c|}{$\begin{array}{l}\text { 11. O diagnóstico do paciente é conhecido pelo } \\
\text { profissional } \\
\begin{array}{llll}\text { () SIM } & \text { ( ) NÂO }\end{array}\end{array}$} \\
\hline $\begin{array}{l}\text { 12. Idade do } \\
\text { paciente }\end{array}$ & $\begin{array}{l}\text { 13. Sexo do } \\
\text { paciente }\end{array}$ & \multicolumn{4}{|c|}{$\begin{array}{l}\text { 14. Categoria do paciente } \\
\text { ( ) SUS ( ) CONVÊNIO } \\
\text { ( ) PARTICULAR }\end{array}$} \\
\hline \multicolumn{6}{|c|}{$\begin{array}{l}\text { 15. Tipo de procedimento } \\
\begin{array}{lll}\text { () Rotina } & \text { ( ) Urgência }\end{array}\end{array}$} \\
\hline \multicolumn{6}{|c|}{ DESCRIÇÃO DO PROCEDIMENTO } \\
\hline & & & & Sim & Não \\
\hline \multicolumn{6}{|c|}{ 1. Lavagem das mãos antes do procedimento } \\
\hline \multicolumn{6}{|c|}{ 2. Uso de luvas para o procedimento } \\
\hline \multicolumn{6}{|c|}{ 3. Descarte da agulha, de imediato } \\
\hline \multicolumn{6}{|c|}{ 4. Descarte da agulha em recipiente rígido } \\
\hline \multicolumn{6}{|c|}{$\begin{array}{l}\text { 5. Re-encape da agulha } \\
\text { 6. Lavagem das mãos após procedimento }\end{array}$} \\
\hline \multicolumn{6}{|c|}{$\begin{array}{l}\text { COMPLEMENTAÇÃO DOS DADOS DE INFRA-ESTRUTURA - } \\
\text { OBSERVAÇÃO }\end{array}$} \\
\hline \multicolumn{6}{|c|}{ 1. Luva Disponível } \\
\hline \multicolumn{6}{|c|}{ 2. Pia próxima } \\
\hline \multicolumn{6}{|c|}{ 3. Sabão dentro do dispensador? } \\
\hline \multicolumn{6}{|c|}{ 4. Disponibilidade de papel toalha } \\
\hline $\begin{array}{l}\text { 5. Recil } \\
\text { e pró }\end{array}$ & $\begin{array}{l}\text { te para descarte de } n \\
\text { o? Quantos metros? }\end{array}$ & terial pé & sponível & & \\
\hline
\end{tabular}




\section{ANEXO III}

\section{Roteiro para a Entrevista com os profissionais de saúde dos hospitais}

01. Fale-me um pouco sobre o que você faz no dia-a-dia no seu trabalho no hospital.

02. Estas suas atividades de rotina envolvem de algum modo, algum risco de contaminação e de contágio pessoal? Fale-me um pouco sobre isso.

03. Você se protege de contaminação e de contágio em suas atividades no hospital? Fale-me sobre isso.

04. Para você o que significa se proteger de uma contaminação/ contágio no hospital?

05. Se você se contaminasse ou se contagiasse durante suas atividades no hospital, qual seria sua reação?

06. Você tem medo de se contaminar/contagiar com algo em especial no hospital? Alguma infecção em especial? Fale-me sobre isso.

07. Biossegurança. Esta palavra significa algo para você?

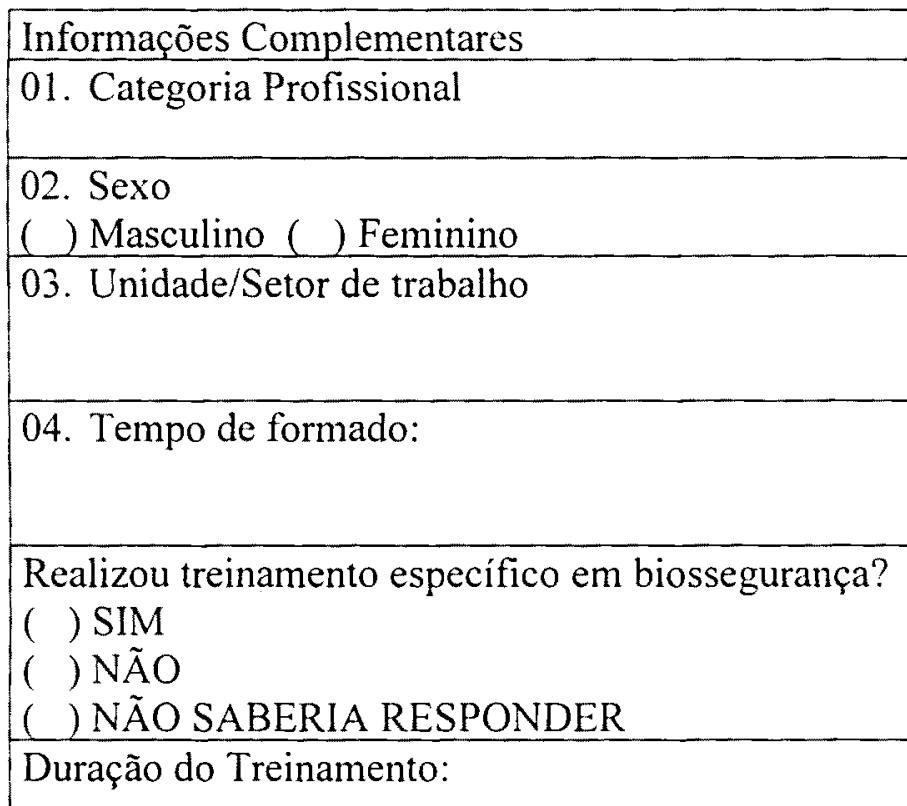

Assuntos abordados: 


\section{ANEXO IV}

\section{Ofício de solicitação de autorização para a Coleta dos Dados}

Prezado (a) Sr (a)

M.D. Diretor (a) do Hospital

Temos a grata satisfação de submeter a V.S. e às instâncias competentes da instituição que dirige, súmula do Projeto de Pesquisa entitulado "Biossegurança para Agentes Biológicos: Um estudo sobre sua implementação e significados do preservar-se e contaminar-se na assistência hospitalar " de autoria da professora Maridalva de Souza Penteado, docente da UESC e aluna do Curso de Doutorado em Saúde Pública da USP, com vistas à autorização para coleta de dados no seu hospital.

De antemão garantimos a total confidencialidade e anonimato da Instituição quando da eventual publicação dos resultados, bem como a total liberdade de, a qualquer momento da pesquisa, retirar seu consentimento.

$\mathrm{Na}$ certeza dos mais especiais préstimos.

Cordialmente,

Dr. Fernando Lefèvre - Orientador

Maridalva de Souza Penteado

Aluna do Curso 


\section{ANEXO V}

\section{TERMO DE CONSENTIMENTO LIVRE E ESCLARECIDO}

Aceito participar da pesquisa "Biossegurança para Agentes Biológicos: Um estudo sobre sua implementação e significados do preservar-se e contaminar-se na assistência hospitalar , de autoria da aluna do Curso de Doutorado em Saúde Pública da USP, Professora Maridalva de Souza Penteado, sob a orientação do Professor Dr. Fernando Lefèvre.

Fui informado que a Pesquisa objetiva analisar a situação de implementação das medidas de biossegurança nos hospitais e estudar o valor do contaminarse/preservar-se pelo profissional de saúde.

Tenho ciência de que em concordando em participar serei entrevistado e/ou observado nas minhas atividades profissionais e que tenho toda a liberdade de me recusar a participar da pesquisa bem como retirar meu consentimento a qualquer nomento da investigação.

Fui também esclarecido(a) que meu nome não será divulgado nos resultados da pesquisa sendo-me garantido total confidencialidade dos dados.

de de 